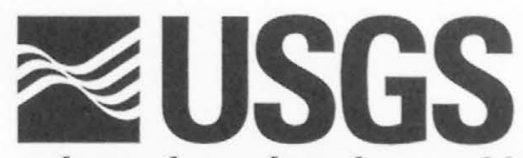

science for a changing world

\title{
Hydrogeology and Water Quality of the Nutmeg Valley Area, Wolcott and Waterbury, Connecticut
}

Water-Resources Investigations Report 99-4081

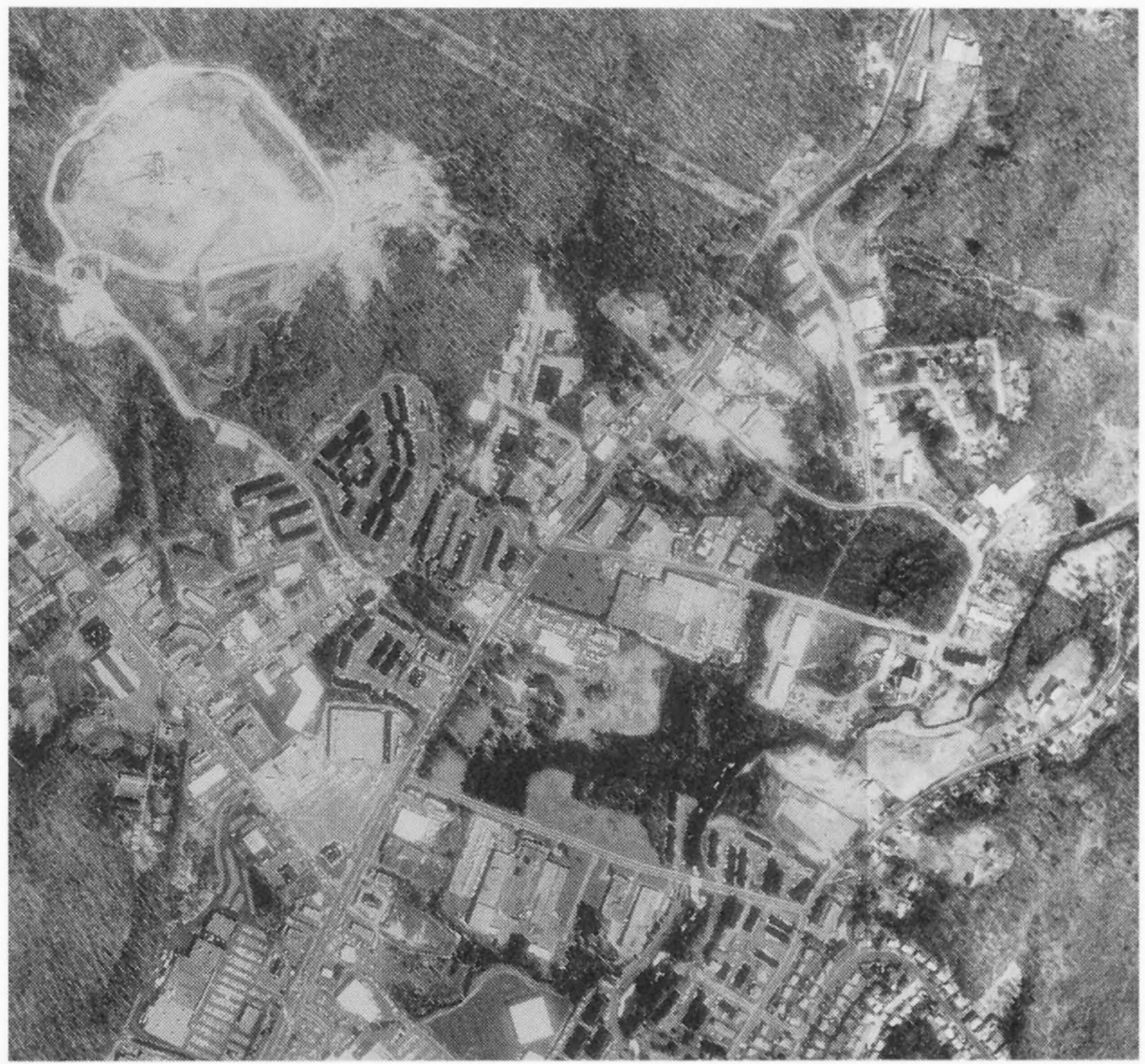

Prepared in cooperation with the Town of Wolcott, Connecticut and the U.S. Environmental Protection Agency

U.S. Department of the Interior U.S. Geological Survey 
Cover: Aerial view of the Nutmeg Valley Area, Wolcott and Waterbury, Connecticut. [From USGS Digital Orthophoto Quadrangles, Waterbury (NE quarter) April 1991 and Southington (NW quarter) April 1992.] 
U.S. Department of the Interior

U.S. Geological Survey

\section{Hydrogeology and Water Quality of the Nutmeg Valley Area, Wolcott and Waterbury, Connecticut}

By John R. Mullaney, Remo A. Mondazzi, and Janet Radway Stone

Water-Resources Investigations Report 99-4081

Prepared in cooperation with the Town of Wolcott, Connecticut and the U.S. Environmental Protection Agency

\section{East Hartford, Connecticut}




\section{U.S. DEPARTMENT OF THE INTERIOR \\ BRUCE BABBITT, Secretary}

\section{U.S. GEOLOGICAL SURVEY}

Charles G. Groat, Director

The use of firm, trade, and brand names in this report is for identification purposes only and does not constitute endorsement by the U.S. Geological Survey.

For additional information write to:

District Chief

U.S. Geological Survey

101 Pitkin Street

East Hartford, CT 06108
Copies of this report can be purchased from:

U.S. Geological Survey

Branch of Information Services

Box 25286, Federal Center

Denver, CO 80225 


\section{CONTENTS}

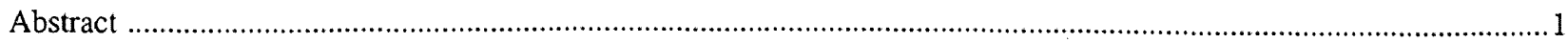

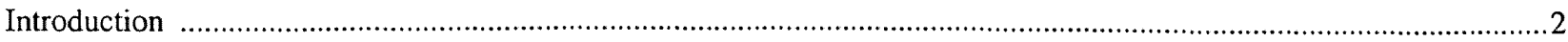

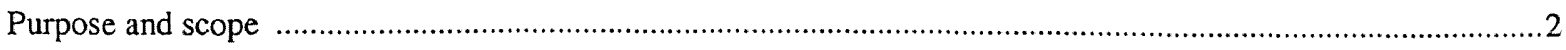

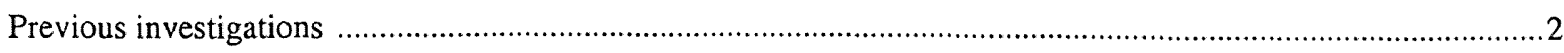

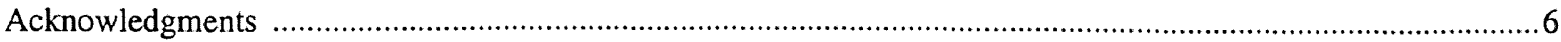

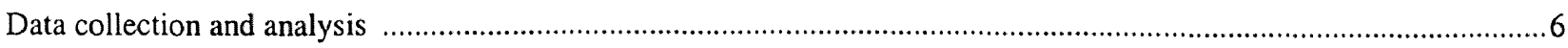

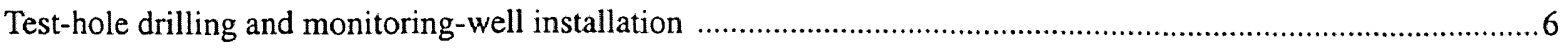

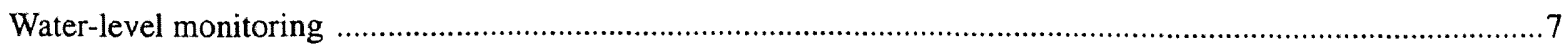

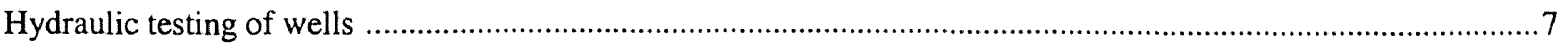

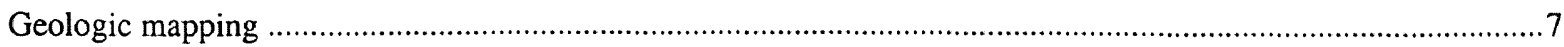

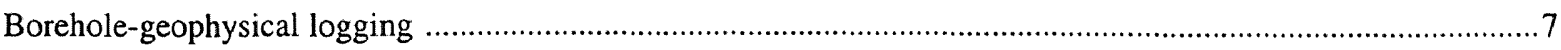

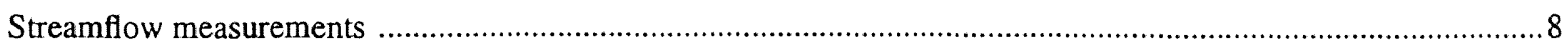

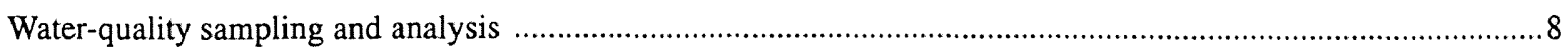

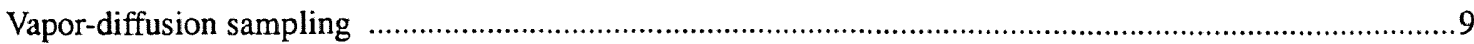

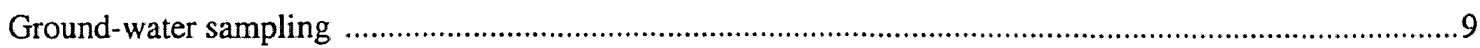

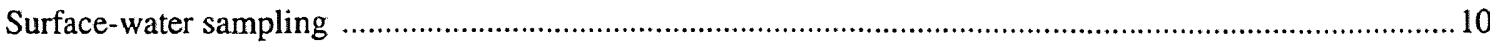

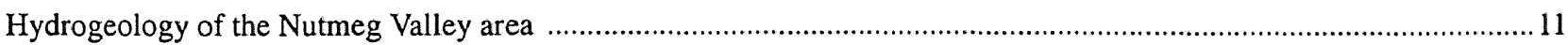

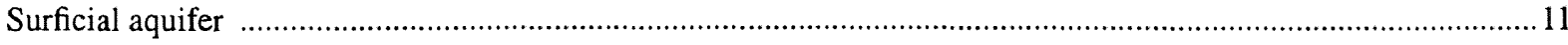

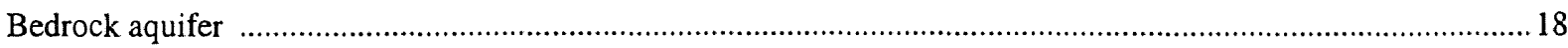

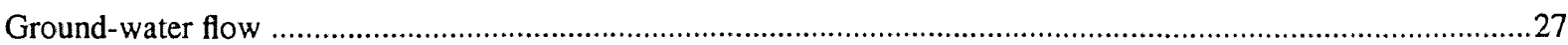

Hydraulic gradients and interaction between surficial and bedrock aquifers ......................................227

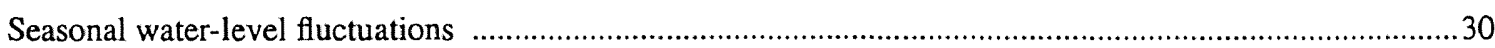

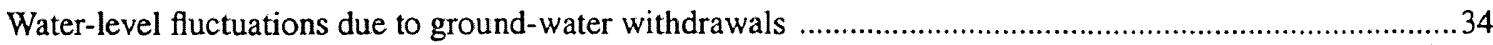

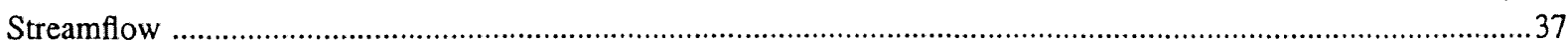

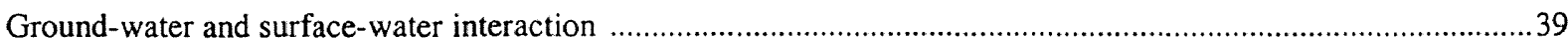

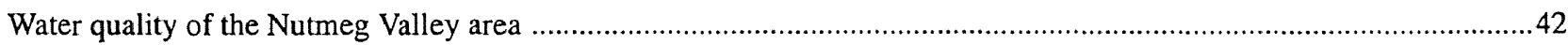

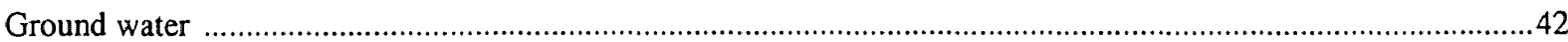

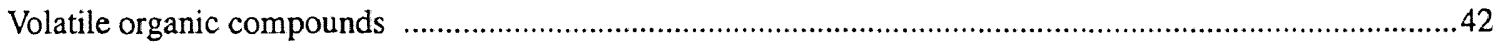

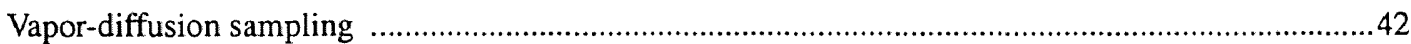

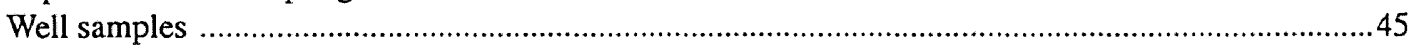

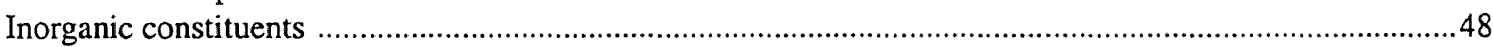

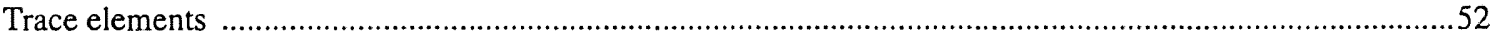

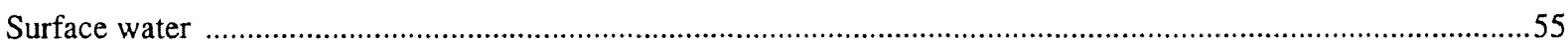

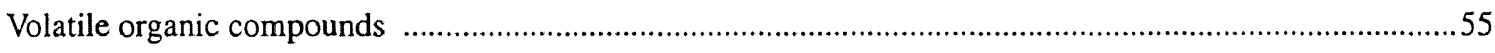

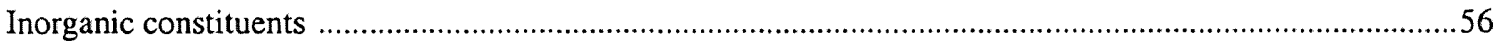

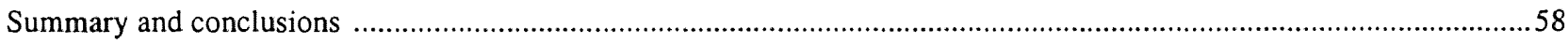

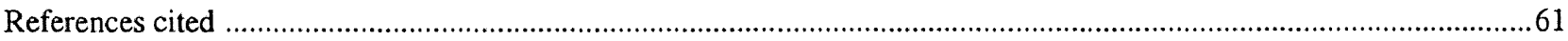


Appendix 1. Lithologic logs of wells in surficial deposits, Nutmeg Valley study area, Wolcott and

Waterbury, Connecticut

Appendix 2. Selected borehole-geophysical logs, Nutmeg Valley study area, 1998

Appendix 3. Water-level altitudes at wells/well clusters measured by the U.S. Geological Survey, 1998 ....................... 72

Appendix 4. Continuous water-level measurements in selected wells in the Nutmeg Valley study area, $1998 \ldots \ldots \ldots \ldots . . . . . .74$

Appendix 5. Rating curves at U.S. Geological Survey streamflow-gaging stations, Nutmeg Valley study area ............... 76

Appendix 6. Vapor-diffusion sampling results in July 1997, Nutmeg Valley study area .............................................. 78

Appendix 7. Vapor-diffusion sampling results in November 1997, Nutmeg Valley study area ...................................... 80

Appendix 8. Selected characteristics of wells inventoried/installed by the U.S. Geological Survey ............................... 83

\section{PLATES}

1. Data-collection locations, Nutmeg Valley study area, Wolcott and Waterbury, Connecticut in pocket

2. Location of current and former occupants, Nutmeg Valley study area, Wolcott and Waterbury,

Connecticut in pocket

\section{FIGURES}

1. Map showing location of the Nutmeg Valley study area and the Nutmeg Valley Superfund Site,

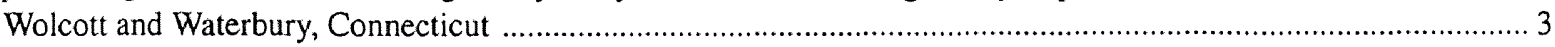

2. Graph showing concentration of trichloroethene at 17 Town Line Road, Wolcott, Connecticut, 1981-98 _.................. 5

3. Map showing distribution of surficial deposits, Nutmeg Valley study area …......................................................... 12

4. Diagrams showing geologic sections A-A' (a), B-B' (b), and C-C' (c) through the Nutmeg Valley study area .............. 14

5. Map showing thickness of surficial deposits in the Nutmeg Valley study area ...................................................... 17

6. Map showing bedrock-surface altitudes, location of bedrock outcrops, and location of bedrock wells in which fracture orientations and flow measurements were made, Nutmeg Valley study area .................................. 19

7. Borehole images showing different rock types and examples of fractures, Nutmeg Valley study area ........................ 20

8. Orientation of fractures planes measured in outcrops and bedrock wells................................................................... 22

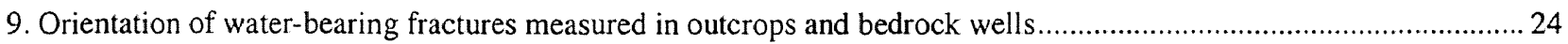

10. Caliper logs with percentage of flow (from heat-pulse flowmeter tests) in specific water-bearing fractures ................ 25

11. Map showing altitude of the water table and direction of shallow ground-water flow in surficial aquifers, Nutmeg Valley study area, September 1-3, 1998

12. Map showing altitude of the potentiometric surface and generalized ground-water-flow direction in the bedrock aquifer, Nutmeg Valley study area, September 1-3, 1998

13. Graph showing water-level altitudes at wells WC $84-86$ screened in surficial deposits, Wolcott, Connecticut, April to September 1998

14. Diagram showing conceptual model of ground-water flow in section $A 1-A^{\prime}$, based on water-level measurements made September 1-3, 1998, Nutmeg Valley study area

15. Diagram showing conceptual model of ground-water flow in section $\mathrm{B}-\mathrm{B} 11^{\prime}$, based on water-level measurements made September 1-3, 1998, Nutmeg Valley study area

16. Graph showing water levels in well WB 93, Waterbury, Connecticut, 1997-98 and median monthly water levels for the period of record

17. Graph showing continuous water levels at well WC 85 , screened in stratified glacial deposits, Wolcott, Connecticut, and daily precipitation at Burlington, Connecticut, April to October 1998 


\section{FIGURES-Continued}

18. Graph showing water levels in wells WC 38 and WC 41, 1240 Wolcott Road, Wolcott, Connecticut, April to May 1998

19. Graph showing water-level fluctuations in well WB 406, Sharon Road, Waterbury, Connecticut, September to November 1998

20. Graph showing water-level fluctuations in well WC 99, Tosun Road, Wolcott, Connecticut, May to June 1998 .........37

21. Map showing locations where vertical gradient was measured between streams and ground water, Nutmeg Valley study area, November 1997

22. Map showing distribution and concentration of trichloroethene and tetrachloroethene in streambeds by vapor-diffusion sampling and analysis method, Nutmeg Valley study area, July 1997

23. Map showing distribution and concentration of trichloroethene, tetrachloroethene, cis 1,2-dichloroethene, and benzene in streambeds by vapor-diffusion sampling and analysis method, Nutmeg Valley study area, November 1997

24. Map showing detections of volatile organic compounds in wells sampled May to September 1998 in the Nutmeg Valley study area

\section{TABLES}

1. Description of surface-water discharge and water-quality sampling stations in and near the Nutmeg Valley study area, Wolcott and Waterbury, Connecticut 8

2. Analytical methods used to analyze samples from the Nutmeg Valley study area, July to September 1998 ................. 10

3. Hydraulic conductivity of surficial deposits estimated from slug-test analysis, Nutmeg Valley study area ................... 18

4. Measurements of stream discharge in and near the Nutmeg Valley study area, 1996-98 …......................................... 38

5. Stream-discharge measurements made during low-flow sampling, July 27-28, 1998, Nutmeg Valley study area ......... 39

6. Measurements of vertical hydraulic gradient between surface water and ground water, and specific conductance measurements in surface water and substream ground water at vapor-diffusion sampling locations along streams draining the Nutmeg Valley study area, November 1997 and July 1998

7. Concentrations of volatile organic compounds in vapor and ground water and field measurements for surfacewater and ground-water quality at the downstream end of Old Tannery Brook, Nutmeg Valley study area, November 12 and 17, 1997

8. Detections of volatile organic compounds in ground-water samples collected May to September 1998 in the Nutmeg Valley study area

9. Field measurements and concentrations of major ions and cyanide in samples collected from wells in the Nutmeg Valley study area

10. Concentrations of dissolved trace elements detected in samples collected from wells in the Nutmeg Valley study area

11. Concentrations and instantaneous loads of volatile organic compounds detected in surface-water samples from the Nutmeg Valley study area, July 1998

12. Values of field measurements in surface-water samples collected in the Nutmeg Valley study area, July 1998 ......... 56

13. Concentrations of dissolved anions, cations, and cyanide in surface-water samples collected in the Nutmeg Valley study area, July 1998

14. Concentrations of trace elements detected in surface-water samples collected in the Nutmeg Valley study area, July 1998 


\begin{tabular}{|c|c|c|}
\hline Multiply & By & To obtain \\
\hline \multicolumn{3}{|c|}{ Length } \\
\hline inch (in.) & 25.4 & millimeter \\
\hline \multirow[t]{2}{*}{ foot $(f t)$} & 0.3048 & meter \\
\hline & Area & \\
\hline \multirow[t]{2}{*}{ square mile $\left(\mathrm{mi}^{2}\right)$} & 2.590 & square kilometer \\
\hline & Flow rate & \\
\hline cubic foot per second $\left(\mathrm{ft}^{3} / \mathrm{s}\right)$ & 0.02832 & cubic meter per second \\
\hline gallon per minute (gal/min) & 0.06309 & liter per second \\
\hline gallon per day (gal/d) & 0.003785 & cubic meter per day \\
\hline million gallons per day (Mgal/d) & 0.04381 & cubic meter per second \\
\hline \multicolumn{3}{|l|}{ million gallons per day per square mile } \\
\hline \multirow[t]{2}{*}{ inch per year (in/yr) } & 25.4 & millimeter per year \\
\hline & Pressure & \\
\hline \multirow[t]{2}{*}{ pound per square inch $\left(\mathrm{lb} / \mathrm{in}^{2}\right)$} & 6.895 & kilopascal \\
\hline & Hydraulic conductivity & \\
\hline foot per day $(\mathrm{ft} / \mathrm{d})$ & 0.3048 & meter per day \\
\hline
\end{tabular}

Temperature in degrees Celsius $\left({ }^{\circ} \mathrm{C}\right)$ may be converted to degrees Fahrenheit $\left({ }^{\circ} \mathrm{F}\right)$ as follows:

${ }^{\circ} \mathrm{F}=\left(1.8 \times{ }^{\circ} \mathrm{C}\right)+32$

Temperature in degrees Fahrenheit $\left({ }^{\circ} \mathrm{F}\right)$ may be converted to degrees Celsius $\left({ }^{\circ} \mathrm{C}\right)$ as follows:

${ }^{\circ} \mathrm{C}=\left({ }^{\circ} \mathrm{F}-32\right) / 1.8$

Vertical datum: In this report, "sea level" refers to the National Geodetic Vertical Datum of 1929 (NGVD of 1929)—a geodetic datum derived from a general adjustment of the first-order level nets of both the United States and Canada, formerly called Sea Level Datum of 1929.

Altitude, as used in this report, refers to distance above or below sea level.

Specific conductance is given in microsiemens per centimeter at 25 degrees Celsius $\left(\mu \mathrm{S} / \mathrm{cm}\right.$ at $\left.25^{\circ} \mathrm{C}\right)$.

Concentrations of chemical constituents in water are given either in milligrams per liter $(\mathrm{mg} / \mathrm{L})$ or micrograms per liter $(\mu \mathrm{g} / \mathrm{L})$. Concentrations of chemical constituents in soil are given in micrograms per kilogram $(\mu \mathrm{g} / \mathrm{kg})$.

Load is given in grams per day $(\mathrm{g} / \mathrm{d})$.

Vapor-diffusion sampling results are reported in parts per billion (ppb) by volume. 


\title{
Hydrogeology and Water Quality of the Nutmeg Valley Area, Wolcott and Waterbury, Connecticut
}

\author{
By John R. Mullaney, Remo A. Mondazzi, and Janet Radway Stone
}

\section{ABSTRACT}

Hydrogeologic investigations in an industrial area in Wolcott and Waterbury, Connecticut, have provided information on the geology, ground-water flow, and water quality of the area. Ground-water contamination by volatile organic compounds was discovered in the 1980's in the Nutmeg Valley area, where approximately 43 industries and 25 residences use ground water for industrial and domestic supply. Unconsolidated surficial deposits, including glacial stratified deposits and till, are more than 85 feet thick and are interconnected with the underlying bedrock. The horizontal hydraulic conductivity of the stratified deposits ranges from 0.8 to 21 feet per day.

Water in the surficial aquifer generally flows toward discharge points along Old Tannery Brook and the Mad River. Water in the bedrock aquifer flows through low-angle unroofing joints, highangle fractures, and foliation-parallel fractures. Most high-angle water-bearing fractures strike north with an easterly dip. Most of the water pumped from bedrock wells in the study area comes from shallow fractures that are probably in hydraulic connection with the surficial aquifer.

Short-circuit flow between fracture zones in wells is a likely pathway for contaminant transport. During periods of low streamflow, only a small amount of ground water discharges directly to Old Tannery Brook or to the Mad River. The amount of discharge is on the same order of magnitude as the estimated ground-water withdrawals.

In northern parts of the valley bottom within the study area, downward vertical hydraulic gradients were present between wells in the surficial and bedrock aquifers. In southern parts of the valley, however, vertical gradients were upward from the bedrock to the surficial aquifer. Vertical gradients can change seasonally in response to different amounts of ground-water recharge and to stresses caused by ground-water withdrawals, which can in turn facilitate the spread of contamination.

Vapor-diffusion samplers were installed in streambeds to identify zones where water containing volatile organic compounds was discharging to streams in the study area. Three areas with high vapor concentrations of trichloroethene and tetrachloroethene were identified. Concentrations of trichloroethene as high as 30,000 parts per billion by volume were detected.

Three of 44 wells sampled contained concentrations of volatile organic compounds, including trichloroethene and tetrachloroethene, above primary drinking water standards. Based on the findings of this and previous investigations, water in the bedrock aquifer in the southern part of the study area is likely to contain trichloroethene, tetrachloroethene, and 1,1,1-trichloroethane. Volatile organic compounds also were detected in stream samples from the downstream end of Old Tannery Brook and the Mad River. Concentrations of major ions and trace elements (with one exception) did not exceed primary drinking water standards in any ground-water or surface-water samples collected.

Ground-water samples collected downgradient from the Waterbury North End Disposal Area contained ethyl ether, chlorobenzene, and elevated concentrations of dissolved solids, similar to samples of landfill leachate and groundwater samples collected from springs and wells adjacent to the landfill. 


\section{INTRODUCTION}

Ground-water contamination by volatile organic compounds (VOCs) and inorganic constituents has been identified in an industrial area along the Route 69 corridor near the Wolcott/Waterbury, Connecticut town line. The area commonly is referred to as the Nutmeg Valley Superfund Site (fig. 1). The area was classified by the U.S. Environmental Protection Agency (USEPA) as a Superfund site on the National Priorities List on March 31, 1989 (U.S. Environmental Protection Agency, 1989). Approximately 43 industries and 25 residences in the area withdraw ground water for industrial and domestic supply, primarily from the bedrock aquifer. Past disposal of industrial chemicals has been implicated in contamination of water from supply wells sampled by local, State, and Federal agencies during 1979-95. In addition, a landfill for the City of Waterbury (the North End Disposal Area) is located upgradient from the Nutmeg Valley Superfund Site (fig. 1, pl. 1).

In 1995-96, the U.S. Geological Survey (USGS), in cooperation with the Town of Wolcott and the USEPA, reviewed existing hydrogeologic and waterquality information, and collected new hydrogeologic information near the contaminated areas (Stone and others, 1997). In 1997, a second phase of investigation was begun to collect new information on the hydrogeology and water quality in and near the Nutmeg Valley Superfund Site. This new information will provide a framework that can be used by the USEPA, other regulatory agencies, and private parties to help develop Superfund Remedial Investigation/Feasibility Studies that may be required at individual properties contained in the Nutmeg Valley Superfund Site. The report refers to the "Nutmeg Valley study area" or "study area," which includes the Nutmeg Valley Superfund Site and adjacent areas within one-half mile of the Superfund Site boundaries and is roughly coincident with the extent of the map coverage of plate 1 .

\section{Purpose and Scope}

This report describes the hydrogeology and water quality of the Nutmeg Valley study area in Wolcott and Waterbury, Connecticut. It summarizes previous or ongoing investigations to 1998 and provides new information collected by the USGS in 1997-98 during the second phase of investigation. This information includes an analysis of data collected using vapor- diffusion sampling as a reconnaissance tool to determine the location of VOC-contaminated ground-water discharge to surface water, test-hole and monitoringwell data to determine geology and hydraulic properties, analysis of ground-water levels and water-table fluctuations, ground-water-flow directions, and a detailed analysis of ground-water quality. The report also includes an interpretation of borehole-geophysical logs collected at seven wells in the study area and summarizes information on stream-discharge measurements and surface-water quality at several locations in the study area. The report discusses the interaction between aquifers, as well as the interactions between ground water and surface water and also describes the techniques of investigation, which may have application to other studies in similar hydrogeologic settings.

\section{Previous Investigations}

The hydrogeology of the area was first described by Wilson and others (1974) as part of a regional study of the hydrology of the lower Housatonic River Basin. Surficial geology of the area was described by Stone and others (1992) and LaSala (1961) and the bedrock geology was described by Rodgers (1985), Fritts (1963), and Gates and Martin (1967).

The geohydrology and historical water quality of the Nutmeg Valley Superfund Site and adjacent areas was most recently described by Stone and others (1997). The report contains information on the physiographic, geologic, and hydrologic framework, water use, history of ground-water and soil contamination, and presents a preliminary conceptual model of ground-water flow in the Nutmeg Valley study area. According to this report, the VOCs most commonly detected in supply wells tapping the crystalline-bedrock aquifer included trichloroethene (TCE), tetrachloroethene (PCE), and 1,1,1-trichloroethane (TCA). Concentrations of TCE were as high as $320 \mu \mathrm{g} / \mathrm{L}$ in samples collected from supply wells in 1985 . Stone and others (1997) concluded that concentrations of VOCs have decreased with time in samples from 12 bedrock wells that supply water to businesses in the Nutmeg Valley area. The authors of the study also concluded that at locations where the top of the bedrock was near land surface, the water level in the bedrock aquifer rises quickly in response to precipitation. This has implications for contamination of the bedrock aquifer in these areas. The report also concluded that effective 


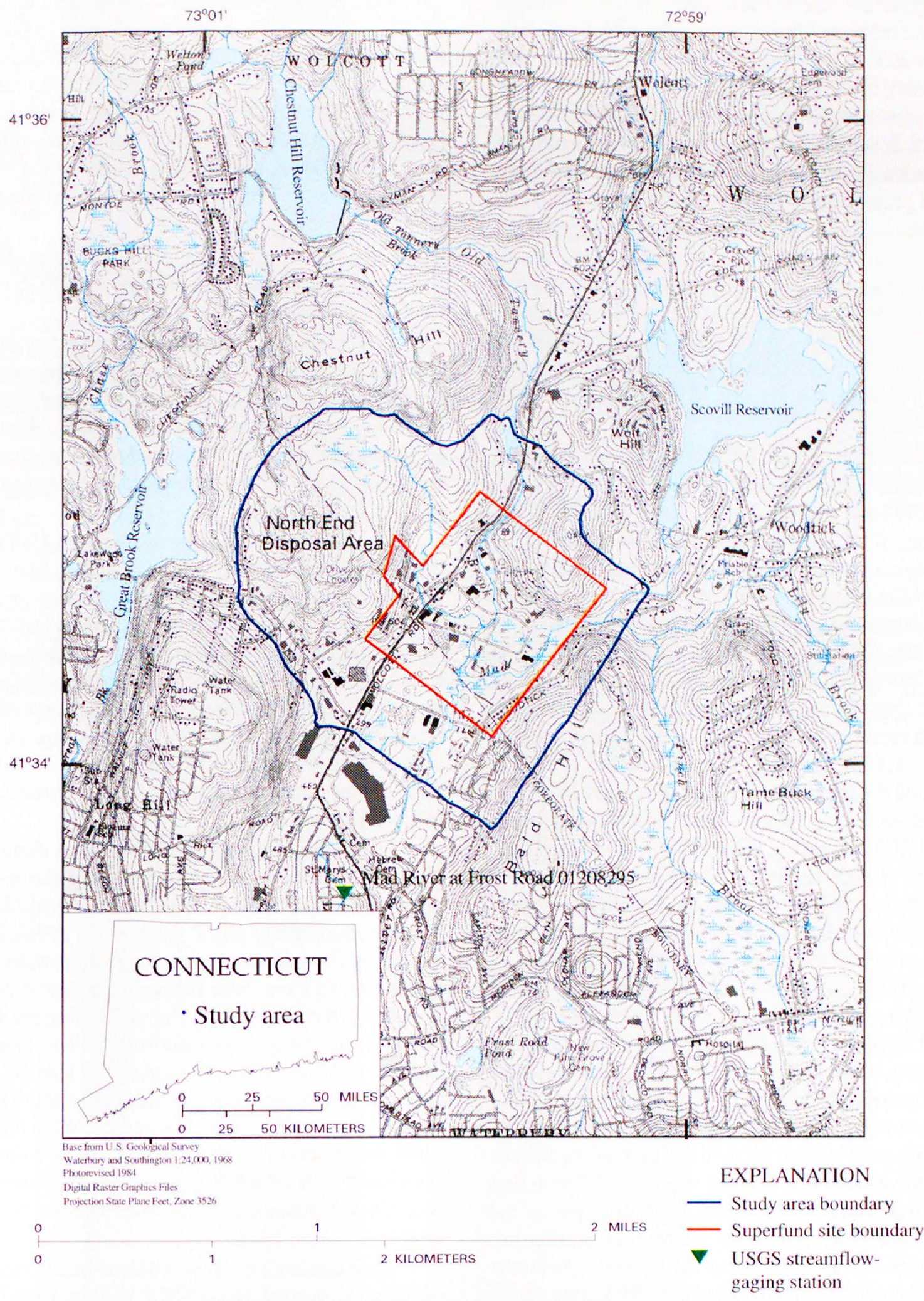

Figure 1. Location of the Nutmeg Valley study area and the Nutmeg Valley Superfund Site, Wolcott and Waterbury, Connecticut. 
annual ground-water recharge (the amount of precipitation that infiltrates into the ground minus the amount lost to evapotranspiration) to aquifers in a $0.9-\mathrm{mi}^{2}$ area surrounding the Nutmeg Valley Superfund site is $14 \mathrm{in} / \mathrm{yr}$, and that 56 percent of the recharge is to stratified-drift areas and 44 percent is to areas covered by till deposits. Stone and others (1997) concluded that past and present pumping from the bedrock aquifer may have facilitated or induced flow of contaminated ground water downward from the surficial aquifer into the bedrock aquifer. The report indicates that an up-todate assessment of the water quality of the stratifieddrift aquifer would be useful because much of the previously collected information was collected over a long period of time for the purpose of examining site-specific problems.

In addition to the work conducted by the USGS, several other studies were conducted or were ongoing during 1997-98. An ongoing site investigation continued during 1997-98 at 1240 Wolcott Rd. (plate 2), focusing on a former lagoon area on the east side of the property that was used until 1977 to treat wastewater from the manufacturing process (Loureiro Engineering Associates, $1998 \mathrm{a}, \mathrm{b}$ ). This area was previously investigated during 1990-95 (HRP Associates, 1996 a, b, c). Loureiro Engineering Associates $(1998 \mathrm{a}, \mathrm{b})$ reported that high concentrations of TCE, cis 1,2-dichloroethene ( $c$ 1,2-DCE) and PCE were detected in soils in and around the former lagoon area in August 1997. The highest detected concentrations of VOCs in soil were TCE-1,200,000 $\mu \mathrm{g} / \mathrm{kg}, c 1,2-\mathrm{DCE}-40,000 \mu \mathrm{g} / \mathrm{kg}$, and PCE $-46,000 \mu \mathrm{g} / \mathrm{kg}$. Total petroleum hydrocarbons were detected in soil from the former lagoon area at concentrations up to $4,790 \mathrm{mg} / \mathrm{kg}$. The lagoon area and other parts of the property are underlain by an organic silt and clay deposit overlying sand. As part of the recent investigations, new well clusters were installed upgradient and downgradient of the former lagoon area. Continuous samples of the unconsolidated deposits were collected for VOC analysis. High concentrations of TCE, $c$ 1,2-DCE, and PCE were detected in the soil samples from areas in and just below the previously mentioned fine-grained deposit. TCE also was present in sediment samples from the bottom part of the sand and gravel aquifer above the bedrock aquifer in two borings downgradient from the former lagoon area (Loureiro Engineering Associates, 1998a). Free-phase solvent was observed in one boring located downgradient from the former lagoon. The highest concentrations of TCE detected in ground-water samples collected from the surficial aquifer in March 1998 was
$180,000 \mu \mathrm{g} / \mathrm{L}$, vinyl chloride-1900 $\mu \mathrm{g} / \mathrm{L}$; and $c 1,2-$ DCE $-40,000 \mu \mathrm{g} / \mathrm{L}$. Samples collected as part of the regular quarterly monitoring continued to show low concentrations of VOCs (primarily TCE) in samples from wells in the bedrock aquifer. The report (Loureiro Engineering Associates, 1998b) states that it is possible that the bedrock aquifer downgradient of the former lagoon may have been affected by on-site contamination of the surficial aquifer.

The following paragraphs summarize other reports or information obtained by the USGS during the second phase of this investigation.

A fuel oil leak from an underground-storage tank was discovered at 7 Town Line Rd. and reported by Connecticut Department of Environmental Protection (CTDEP) personnel in April 1997. Contaminated soil was removed along with two underground-storage tanks (Connecticut Department of Environmental Protection, 1997a).

An oily sheen was discovered by a USEPA contractor and investigated by the CTDEP in May 1997 at 3 Town Line Rd. The CTDEP investigation revealed that an oily seep had entered the unnamed tributary to Old Tannery Brook. Analysis of water samples collected from small-diameter wells installed and sampled by CTDEP personnel indicated the presence of a kerosene-like free-phase product. It was believed that the contamination emanated from a former drum storage area (Connecticut Department of Environmental Protection, 1997b).

A site investigation was conducted during 199798 at 3 Tosun Rd. in the Nutmeg Valley site related to the transfer of ownership of an undeveloped (formerly residential) property (HRP Associates, 1998). No contaminants were discovered in the ground-water samples collected from three bedrock wells or in one well installed in the surficial aquifer underlying the western part of the property. Contaminated soil was discovered beneath and west of an old garage and from an old debris pile. Contaminants included petroleum hydrocarbons, lead, and VOCs. The source of the contaminants was reported by HRP Associates as waste associated with vehicle repair and paint-related products. Contaminated soil was removed from the property.

Soil contamination was discovered during building expansion at 64 Wolcott Rd. in June 1998 (EEW Management, 1998). The contaminated soil was near the location of a former waste-oil underground storage tank, a former drum storage area, and a former septic tank. Soil samples contained high concentrations of 
total petroleum hydrocarbons, napthalene, and lower concentrations of other organic volatile and semi-volatile constituents including TCA, 1,2,4-trimethylbenzene, 1,3,5 trimethylbenzene, acetone, ethylbenzene, isopropylbenzene, methylene chloride, methyl tertbutyl ether (MTBE), $n$-butylbenzene, $o$-xylene, $p$-isopropyltoluene, sec-butylbenzene, PCE, toluene, TCE, $m$ and $p$-xylenes, 1,1-dichloroethene, (1,1 DCE), $c$ 1,2DCE. Many of the compounds also were detected in samples of sediment collected near the water table during the drilling of test borings. Samples collected from the on-site supply well located under the building contained no detectable levels of VOCs or heavy metals. During past sampling rounds conducted in 1981 and 1985 , water from this well contained chloroform, carbon tetrachloride, TCE, pentane, and PCE (Stone and others, 1997).

Regular monitoring continued during 1997-98 at the Waterbury North End Disposal area (Fuss and O'Neill Inc., 1997, and 1998 a,b). The landfill, in the northwestern part of the study area, is in the process of closure and no longer accepts waste. Previous sampling results were described by Stone and others (1997). Samples were collected from seven existing monitoring wells around the landfill, two commercial supply wells on Swiss Lane, one domestic well, the landfill leachate-collection system, and a brook and pond adjacent to the landfill. Samples were analyzed for VOCs, metals, anions, chemical- and biologicaloxygen demand, and other characteristics. Many of the samples collected in October 1997 and January 1998 had specific conductance higher than $500 \mu \mathrm{s} / \mathrm{cm}$, indicating high concentrations of dissolved solids. Concentrations of chloride were 695 and $724 \mathrm{mg} / \mathrm{L}$, respectively, in samples of leachate from the collection system. Several VOCs were detected at low concentrations in the landfill leachate including 1,4-dichlorobenzene, chlorobenzene, $c$ 1,2-DCE, vinyl chloride, benzene, xylenes, and 1,2-dichlorobenzene (Fuss and O'Neill Inc., 1998 a,b). Samples collected from a monitoring well downgradient from the landfill, but upgradient of Swiss Lane (MW-J, WC 49) had high alkalinity and high concentrations of chloride and manganese. Samples from this well also contained the VOCs 1,4 dichlorobenzene, chlorobenzene, chloroethane, and benzene.

Information on VOC samples collected from 1981-95 was provided to the USGS by one property owner for the supply well at 17 Town Line Rd. (Joseph Macary, Joma, Inc., written commun., 1998 and HRP Associates, 1995) Analysis of the data shows a declining concentration in VOCs, primarily TCE, since 1985 (fig. 2). A sample collected from this well (WC 101, pl. 1) by the USGS is included on figure 2 .

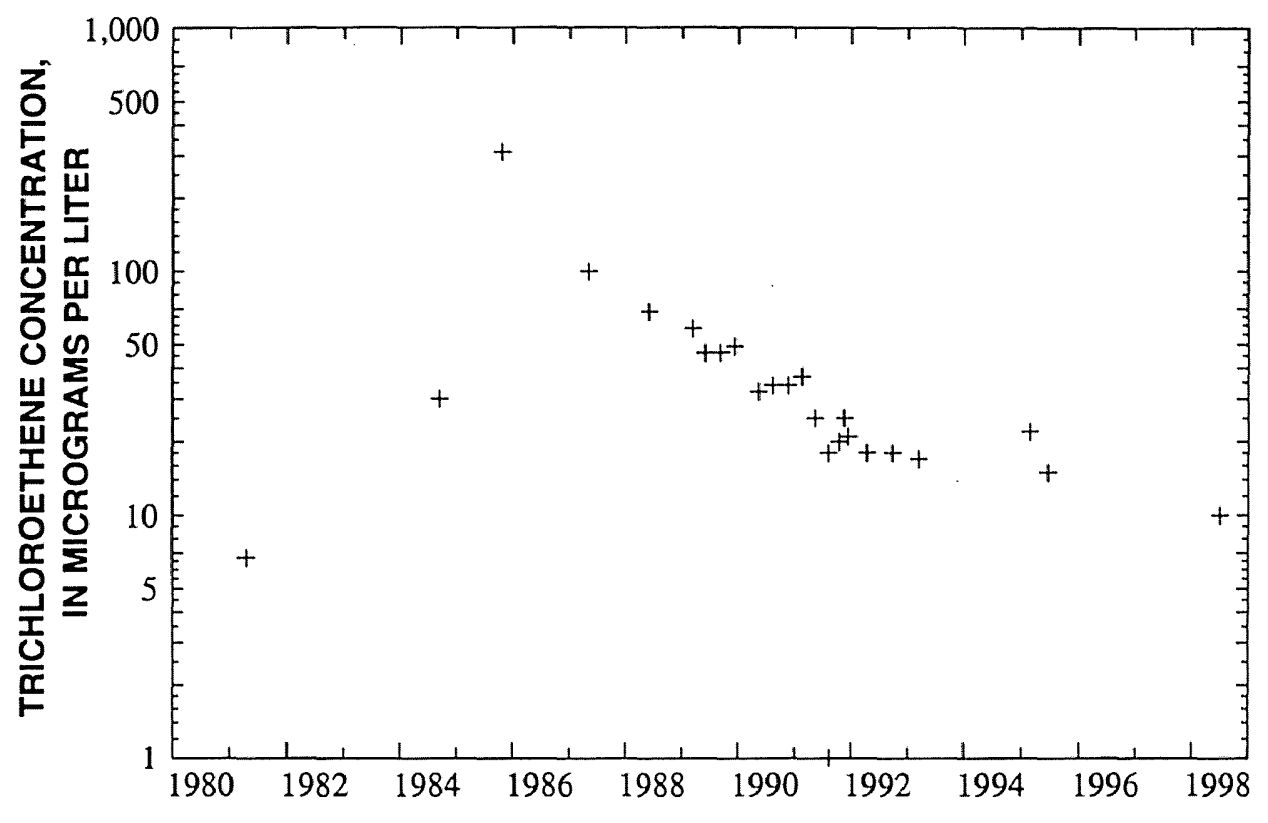

Figure 2. Concentration of trichloroethene at 17 Town Line Road, Wolcott, Connecticut, 1981-98. 


\section{Acknowledgments}

We would like to thank the many individuals, corporations, and government officials who provided information, assistance, and access to private property, including but not limited to Robert Hank and Bud Hansen (Highland Manufacturing), LEA Associates, HRP Associates, Fuss and O'Neill Inc., National Die Company, Mattatuck Scrap Metal, the Sendzimir estate, Joseph Macary, Roann Electronics, Marson Corporation, Secondaries Inc., Cly-Del Manufacturing Company, John Hytchko, Eleanor McVerry, Joseph Pagano, Brian Borghesi, numerous Tosun Road residents, James Hickey (U.S. Postal Service), the Town of Wolcott-Stephen Bosco (Mayor), Cory Joseph (Water and Sewer Administrator), and other Public Works Department employees-Brian Lister (City of Waterbury Department of Waste Disposal), and the Chesprocott Health District. We also would like to thank Sheila Gleason and Elsie Patton of the CTDEP, Carolyn PinaSpringer, Richard Willey, John Kilborn, James Murphy, Scott Clifford, and William Andrade of the USEPA, and John Lane, John Williams, Kevin Knutsen, Alton Anderson, George Casey, and Barbara Korzendorfer of the USGS.

\section{DATA COLLECTION AND ANALYSIS}

The methods used to study the hydrogeology and water quality of the Nutmeg Valley study area included (1) test-hole drilling and monitoring-well installation, (2) water-level monitoring, (3) hydraulic (slug) testing of wells drilled in surficial materials, (4) geologic mapping, (5) borehole-geophysical logging, (6) streamflow measuring, and (7) ground-water and surface-water quality sampling, including vapor-diffusion sampling for VOCs.

\section{Test-hole drilling and monitoring-well installation}

Test holes were drilled and observation wells were installed to (1) help further define the geometry of the surficial and bedrock aquifers underlying the Nutmeg Valley study area, and (2) provide locations for water-level measurements, slug tests, water-quality sampling, and borehole-geophysical logging. Drilling sites were selected in areas where geologic and water- quality data were absent and to characterize the hydrogeology of the study area.

Wells were installed in clusters at seven locations in the study area. Data collected at the well clusters were used to determine vertical hydraulic gradients and vertical differences in hydraulic conductivity and water quality. At these locations, wells were installed near or just below the water table and (or) at the bottom of the surficial aquifer. In addition, at five locations, wells were installed in the intermediate part of the surficial aquifer. A total of 18 wells were installed in the surficial aquifer and 7 wells were installed in the crystalline bedrock aquifer (pl. 1) with open intervals to a depth of at least $90 \mathrm{ft}$ below the bedrock surface.

Wells were installed in the surficial aquifer using a hollow-stem auger drill rig operated by USGS personnel. At most sites, split-spoon samples were collected every 5 to $10 \mathrm{ft}$ down to bedrock or refusal to determine changes in lithology. The split-spoon samples were chemically screened with a photoionization detector to determine the presence of VOCs. The splitspoon sampler was cleaned with a soap/tap water solution after each use. After reviewing the field notes and lithologic information, up to three depths in the surficial aquifer were selected for monitoring-well installation. Wells were constructed of 2-in. schedule-40 polyvinyl chloride (PVC) casing and 2-ft slotted 0.010in. well screens. Short well screens $(2 \mathrm{ft}$ ) were used to ensure that water-level measurements and water-quality samples represented discrete parts of the surficial aquifer. Wells were completed by packing the screened interval, and the overlying 5 to $10 \mathrm{ft}$, with silica sand or by allowing aquifer materials to collapse around the well screens during removal of the hollow-stem augers. The remaining annulus around the wells was sealed with at least $5 \mathrm{ft}$ of either a bentonite slurry or bentonite pellets placed above the screened interval. The remainder of the hole was backfilled with collapsed material or drill cuttings from the hole. A locking cover and cement seal were placed at land surface. All drill tools were steam cleaned after completion of each hole.

Bedrock monitoring wells were installed by a private contractor using mud-rotary and air-rotary percussion drilling. The overburden was drilled with an 8in. rollerbit, using air or mud-rotary methods, depending on the thickness and composition of the surficial deposits. At least $20 \mathrm{ft}$ of 6 -in. steel casing was installed to a minimum of $4 \mathrm{ft}$ below the bedrock surface. The interface between bedrock and overburden was grouted with Portland cement in four wells. 
Because of difficult drilling conditions, three of the seven bedrock wells were not grouted; however, at these locations, casing was driven up to an additional $20 \mathrm{ft}$ into bedrock. Drilling continued to at least $90 \mathrm{ft}$ below the bedrock surface. Drilling logs for well cluster locations are shown in appendix 1.

\section{Water-level monitoring}

Ground-water levels were measured at newly installed wells and some existing wells to determine (1) water-table altitude and general ground-water-flow direction, (2) vertical hydraulic gradients between selected depths in the surficial and bedrock aquifers, (3) the range of ground-water-level fluctuations in recharge versus discharge-dominant parts of the ground-water flow system, and (4) locations where nearby ground-water withdrawals affect water levels.

To accomplish these goals, water levels were measured in three different ways: (1) water levels were measured manually in 75 wells during September 1-3, 1998 to create water-table and potentiometric surface maps; (2) water levels were measured manually on a monthly basis in 25 wells drilled for this study; and (3) water levels were measured continuously with pressure transducers in selected wells for varying periods of time to determine the effects of withdrawals on water levels.

\section{Hydraulic testing of wells}

Slug tests were conducted in 13 wells in the study area using an air-pressurized method for inducing an instantaneous change in the water column in the well. The pressure transducer was lowered into the well after the depth to the water surface from a measuring point was measured with an electric tape. The pressure transducer was connected to a portable computer allowing continuous monitoring of water-level changes. After the water level in the well had stabilized, the system was pressurized with approximately $5 \mathrm{lb} / \mathrm{in}^{2}$ from a portable air tank. The water level was monitored until stable conditions were again achieved. A quick-release valve was opened at this time to release the air pressure in the casing and begin the recovery part of the slug test. The water level was allowed to recover to within a few hundredths of a foot of the stable water level, and the test was terminated.
Multiple slug tests were performed at four wells to determine the reproducibility of the tests.

The slug tests were analyzed using methods described by Bouwer and Rice (1976) for unconfined aquifers with partially penetrating wells and methods described by Cooper and others (1967) for confined aquifers with fully penetrating wells.

\section{Geologic mapping}

Geologic mapping was conducted to delineate the extent and physical properties of the surficial materials and the lithology and structure of the underlying bedrock. All available exposures of surficial materials and bedrock were examined, and the strike and dip of bedrock fractures and foliation were measured. Aerial photographs was used to delineate geologic contacts where there were no exposures of surficial materials. Early aerial photographs (1965) were used to view landforms and surficial deposits prior to development, so that materials beneath areas of more recent excavation or filling could be mapped. All lithologic logs from wells and test holes were analyzed, and geologic sections were constructed from this information.

\section{Borehole-geophysical logging}

Borehole-geophysical logs were obtained in eight bedrock wells in the study area during May and June 1998. The primary purpose of borehole logging was to determine the location and orientation of waterbearing fractures in each well. The location and orientation of fractures was determined primarily with the use of caliper, fluid conductivity and temperature, down-hole television camera, borehole image processing system (BIPS), and acoustic televiewer (ATV) logging tools. Heat-pulse flowmeter logs were run under static and pumping conditions to determine the location of water-bearing fractures. Another reason for logging was to determine the lithology of the bedrock. This was done primarily with the use of the natural gamma, television camera, and BIPS. In addition, formational resistivity, borehole radar (two wells), and boreholedeviation logs were obtained.

Many of the borehole-geophysical techniques that were used are described by Keys (1990). The principal application of many of the borehole-geophysical tools is shown in Melvin and others (1995, table 1). Selected logs are shown in appendix 2; the remainder are on file at the U.S. Geological Survey office in East Hartford, Connecticut. 


\section{Streamflow measurements}

During 1996-97, as part of the first phase of this investigation, streamflow was measured intermittently at two sites on the Mad River, one site on Old Tannery Brook, one site on an unnamed tributary to Old Tannery Brook, and one site on the Mad River outside the study area (Stone and others, 1997). Streamflow measurements continued at these sites (table 1) during 1997 and 1998 to develop a stage-to-discharge relation (rating curve) for each station. Three additional stations were established and measured once or twice when surface-water samples were collected. No rating curve was established for these water-quality stations. Stream stage was determined by measuring down from a reference point near each of the five sites where a stage-todischarge relation was established. Stream stage and discharge were measured using methods described by Rantz (1982). Streamflow measurements made using these methods are subject to an accuracy of plus or minus 5 percent under good conditions.

\section{Water-quality sampling and analysis}

Samples were collected during 1997-98 to determine the current water quality of the study area. Types of samples collected by the USGS included vapor-diffusion samples, ground-water samples, and surfacewater samples. Vapor-diffusion samples were collected during July and November 1997. Ground-water samples were collected from May to September 1998. Surface-water samples were collected in July 1998. In addition to the samples collected by the USGS, the Chesprocott Health District collected and analyzed ground-water samples for VOCs from a mixture of 35 residential and commercial properties in the Nutmeg Valley study area during July and August of 1998 (Lorraine DeNicola, Chesprocott Health District, written commun., 1998).

Table 1. Description of surface-water discharge and water-quality sampling stations in and near the Nutmeg Valley study area, Wolcott and Waterbury, Connecticut

\begin{tabular}{clcc}
\hline $\begin{array}{c}\text { U.S. Geological } \\
\text { Survey identifier }\end{array}$ & \multicolumn{1}{c}{ Location } & $\begin{array}{c}\text { Drainage area } \\
\text { in square miles }\end{array}$ & $\begin{array}{c}\text { Water-quality } \\
\text { samples collected }\end{array}$ \\
\hline 01208270 & Mad River below Finch Brook, Wolcott, Connecticut & 12.4 & yes \\
01208280 & Old Tannery Brook at Tosun Road, Wolcott, Connecticut & 2.74 & yes \\
01208283 & $\begin{array}{l}\text { Unnamed tributary to Old Tannery Brook upstream of } \\
\text { Swiss Lane, Wolcott, Connecticut }\end{array}$ & .23 & yes \\
01208285 & $\begin{array}{l}\text { Unnamed tributary to Old Tannery Brook at Wolcott } \\
\text { Rd., Wolcott, Connecticut }\end{array}$ & .45 & no \\
01208286 & $\begin{array}{l}\text { Unnamed tributary to Old Tannery Brook above conflu- } \\
\text { ence with Old Tannery Brook, Wolcott, Connecticut }\end{array}$ & .64 & yes \\
01208288 & $\begin{array}{l}\text { Old Tannery Brook above confluence with Mad River, } \\
\text { Waterbury, Connecticut }\end{array}$ & 3.71 & yes \\
01208290 & $\begin{array}{l}\text { Mad River at Sharon Road, Waterbury, Connecticut } \\
\text { Mad River at Frost Road, Waterbury, Connecticut } \\
\text { (Shown in fig. 1) }\end{array}$ & 16.0 & yes \\
\hline
\end{tabular}




\section{Vapor-diffusion sampling}

Areas where VOC-contaminated ground water was discharging to surface water were delineated using vapor-diffusion collectors installed in the bottom sediments of the Mad River, Old Tannery Brook, and an unnamed tributary of Old Tannery Brook. The method used was similar to that described by Vroblesky and others (1996).

Vapor-diffusion collectors were prepared by placing a clean, uncapped $40-\mathrm{mL}$ vial in a polyethylene bag and removing excess air from the bag so that one smooth layer of polyethylene tightly covered the opening of the vial; this created a membrane permeable to VOCs but not to water. Strapping tape or cable ties were used around the outside of the bag to wrap the polyethylene firmly against the vial. The VOC vial and bag were then placed inside another sealable polyethylene bag. The second bag was sealed using the same approach. The outer bag was used to reduce abrasion of the inner bag, to prevent residual carryover of contamination by keeping the inner bag from contacting contaminated soil, and to optimize the integrity of the bottle seal by eliminating sand from bottle threads. For sample replication, two individually wrapped $40-\mathrm{mL}$ vials were placed in the same outer bag and sealed. The vapor-diffusion collector, which then consisted of one or two uncapped $40-\mathrm{mL}$ glass vials enclosed in two sealable polyethylene bags, was attached to a wire survey flag to be easily located during retrieval. Upon retrieval, the outer bag was removed and the vial was immediately sealed with a septum cap (Vroblesky and others, 1996).

Installation of each vapor-diffusion collector was accomplished using a 14-in. garden spade to open an approximately $1-\mathrm{ft}$ deep cavity in the stream sediment. A vapor-diffusion collector was placed in the cavity, and the streambed material collapsed around the collector as the spade was withdrawn. The remaining hole was backfilled with the surrounding streambed sediment. The distance between collectors ranged from 100 to $200 \mathrm{ft}$ along the streams. Collectors were placed in the center of the streams and in transects across the stream at selected locations.

Vapor-diffusion collectors were installed at 154 locations in the streambed sediments of the Mad River, Old Tannery Brook, and the unnamed tributary to Old Tannery Brook from May 12-27, 1997 and subsequently retrieved from July 8-10, 1997. Fifteen replicates were collected. Vapor-diffusion collectors for the second sampling round were installed at 128 locations on the same three streams from October 23-28, 1997 and retrieved from November 11-13, 1997. Eight replicates were collected.

Vapor-diffusion samples were analyzed in the field by USEPA personnel operating a portable gas chromatograph with a photo-ionization detector and using an air-screening method for VOCs (U.S. Environmental Protection Agency, 1998).

Six substream ground-water samples were collected on November 12 and 17, 1997, for comparison with vapor-diffusion samples, from an area along Old Tannery Brook where high concentrations of TCE were detected during both rounds of vapor-diffusion sampling. A stainless-steel mini-piezometer and a manometer similar to that described by Winter and others (1988) was used to collect substream ground-water samples and to measure vertical hydraulic gradients. To collect the samples, the mini-piezometer was driven to a depth of 1.5 to $3.5 \mathrm{ft}$ below the streambed. A fluidmetering pump with a teflon hose was attached to the piezometer, and the water was purged for a short time. Temperature, specific conductance, $\mathrm{pH}$, and dissolved oxygen were measured during purging. When the water cleared, samples were collected for VOCs in $40-\mathrm{mL}$ glass amber vials and preserved with 1:1 hydrochloric acid. One water sample was collected during the retrieval of the vapor-diffusion samplers and was screened for TCE and PCE by the method used for the vapor samples. Five other water samples, collected 1 week after the vapor-diffusion samplers were retrieved, were sent to the USEPA Region I laboratory in Lexington, Massachusetts, for quantitative analysis by USEPA method 524.2.

Thirty-nine measurements of the verticalhydraulic gradient between the ground water and streams were made at selected locations where vapordiffusion samples were collected. The purpose of the gradient measurements was to determine where upward gradients were present to assist in interpretation of the vapor-diffusion data. Specific conductance of the ground water and surface water also was measured at many of these locations.

\section{Ground-water sampling}

The purpose of the ground-water sampling program was to determine the water quality in (1) the surficial aquifer in areas in the Nutmeg Valley study area that had not been previously sampled, (2) the residential area on Tosun Rd. including two businesses (pl. 1), and (3) the part of the study area adjacent to the North End Disposal Area. Samples were collected from new observation wells installed by the USGS, supply wells at homes and businesses, and from some observation 
wells installed by private consultants. Samples also were collected from one spring adjacent to the North End Disposal Area.

Observation wells in the surficial aquifer were sampled with the use of a small positive-displacement submersible pump constructed of stainless steel and Teflon components. These observation wells were sampled using a low-stress, low-flow sampling technique (U.S. Environmental Protection Agency, Region 1, 1996). Some slight modifications were made to the method because it was very difficult to achieve the 0.3$\mathrm{ft}$ minimum drawdown recommended. Bedrock observation wells were sampled with the same pump and methods; however, the pump intake was placed next to water-yielding fracture zones that were identified during borehole-flowmeter tests.

Water levels in supply wells were measured where possible. Supply wells were sampled with existing pumps at higher flow rates than observation wells, up to several gallons per minute, until the field parameters-temperature, dissolved oxygen, $\mathrm{pH}$, specific conductance, oxidation-reduction potential (ORP), and turbidity - had stabilized and the plumbing system had been purged. Samples were collected from a teflon tube attached to outside taps on the buildings. No wells with treatment (such as softeners or filters) were sampled without disconnecting or bypassing these systems.

Water samples were sent to the USEPA Region I laboratory in Lexington, Massachusetts, for analysis of anions, dissolved trace metals, cyanide, and VOCs. An alkalinity titration was performed on a filtered sample by USGS personnel in the field using methods described by Radtke and Wilde (1998). The methods used for sample analysis are shown in table 2 . In addition to the regular samples collected, quality-assurance/quality-control (QA/QC) samples were collected, including replicates and equipment rinsate blanks. Analytes were selected on the basis of the contamination history as reported by Stone and others (1997).

\section{Surface-water sampling}

The purpose of the surface-water sampling was to determine the quality of water entering and leaving the Nutmeg Valley study area during low-flow conditions when ground-water inflow was the primary source of water to the streams. Surface-water quality samples were collected from six locations (table 1, pl. 1 ) in the study area. Samples were collected for the same constituents and analyzed by the same methods as the ground-water samples listed above. In addition, total (unfiltered) trace element samples were collected at each location. Sampling stations were established on the Mad River in upstream and downstream parts of the study area. Additional stations were established on Old Tannery Brook at Tosun Rd., Old Tannery Brook near the confluence with the Mad River, the unnamed tributary to Old Tannery Brook upstream of industrial areas, and the unnamed tributary to Old Tannery Brook at the confluence with Old Tannery Brook. Samples were collected during low-flow conditions on July 27-28, 1998. River discharge was measured concurrently with the sampling, so that changes in the loads of constituents could be determined between upstream and downstream sampling points. One sample was collected from the upstream site on the unnamed tributary (01208283, pl. 1) during a storm to determine if runoff from the North End Disposal Area was contributing to the water-quality conditions of the study area.

Samples from Old Tannery Brook and the unnamed tributary to Old Tannery Brook were collected using a point-sample method, because the streams were narrow and shallow. Samples (with the exception of VOCs) were collected from the wider and deeper Mad River by compositing samples using an equal-width increment method (Edwards and Glysson, 1988). VOC samples were collected using a point-sample method from the deepest part of the Mad River.

Table 2. Analytical methods used to analyze samples from the Nutmeg Valley study area, Wolcott and Waterbury, Connecticut, July to September 1998

\begin{tabular}{lc}
\hline \multicolumn{1}{c}{ Analysis } & Method and reference \\
\hline Anions & USEPA method 300.0, Ion chromatography (EPA/600/R-93/100) \\
Trace metals and cations & USEPA method 200.7, Inductively coupled plasma using ultrasonic nebulization. \\
& Methods for the determination of metals in environmental samples supplement 1 \\
& (EPA/600/R-94/111) \\
Cyanide & USEPA method 335.2, CLP-M, Method for total cyanide analysis by Midi distillation \\
& (EPA/540/R-95/121) \\
Volatile organic compounds & USEPA method 524.2 Method for determination of organic compounds in drinking \\
& water-supplement III (EPA/600/R-95/131)
\end{tabular}




\section{HYDROGEOLOGY OF THE NUTMEG VALLEY AREA}

Two principal aquifers underlie the Nutmeg Valley study area-an unconsolidated surficial aquifer composed of glacial till, glacial stratified deposits, and postglacial alluvium (hereinafter referred to as the surficial aquifer in this report), and a crystalline bedrock aquifer composed of well-foliated gneiss and granofels. A regional description of the surficial deposits and bedrock geology in the Nutmeg Valley study area, including a description of the physiography and hydrologic framework is given in Stone and others (1997).

\section{Surficial aquifer}

Surficial deposits in the study area consist of glacial till, glacial stratified deposits, and postglacial floodplain deposits (alluvium and swamp) (fig. 3). The subsurface distribution of coarse-grained (sand and gravel) and fine-grained (very fine sand, silt, and clay) textural units varies vertically and laterally within the glacial stratified deposits (figs. $4 a-c$ ). The total thickness of surficial deposits ranges from 0 to greater than $85 \mathrm{ft}$ (fig. 5). The thinnest surficial deposits are in the upland areas on the perimeter of the study area, and the thickest materials lie beneath the Mad River valley.

Glacial till is present at land surface in most of the upland parts of the study area; it is locally absent where bedrock crops out at land surface (fig. 3 ). This material was deposited directly by glacial ice and consists of a nonsorted, nonlayered mixture of grain sizes with a matrix of 65-85 percent sand, $20-30$ percent silt, and (or) 5-10 percent clay; larger rock fragments (including large boulders) generally constitute 20-30 percent of the total volume of material (Melvin and others, 1992b). Till forms a thin (less than 10-ft thick) blanket over bedrock in most places; locally, however, it is thicker. In the study area, till more than $25 \mathrm{ft}$ in thickness is present northeast of the North End Disposal Area, at the south end of the Tosun Rd. residential area, and on a hillside in the southeast part of the study area (fig. 5).

Glacial stratified deposits up to $85 \mathrm{ft}$ in thickness overlie till and bedrock in the Mad River valley; they are present at and below an altitude of $525 \mathrm{ft}$. These materials consist of well sorted to poorly sorted layers of gravel, sand, silt and clay. Coarse-grained deposits of gravel, sand and gravel, and sand are the predominant materials in the Mad River valley; these sediments were deposited by glacial meltwater as deltas in a small glacial lake at and in front of the retreating ice margin.
The subsurface sand and gravel present at wells WC 84-86, WC 80-83, and WC 40 (fig. 4a and b) is the collapsed ice-contact part of a deltaic sequence in the southern part of the study area. Fine-grained deposits overlying the sand and gravel in these same wells and in WC 91-94 are glaciolacustrine sediments that accumulated in the glacial lake in front of the next deltaic sequence to the north. Sands and gravels penetrated in wells WC 106, WC 67, WC 87-90, WC 95-96, and WC 91-94 (fig. 4b, pl. 1) are part of the second deltaic sequence.

Postglacial alluvial and swamp deposits are generally less than $10 \mathrm{ft}$ in thickness and overlie glacial deposits on the floodplain surfaces of the Mad River and Old Tannery Brook. These streams have incised deeply into glacial stratified deposits during postglacial time. The texture of the alluvium beneath the floodplain ranges widely from gravelly sand deposited in former stream channel positions to fine sand and silt with significant amounts of organic material (muck) in overbank deposits laid down during floods.

The horizontal hydraulic conductivity of glacial stratified deposits ranged from 0.8 to $21 \mathrm{ft} / \mathrm{d}$ (table 3 ). The method for slug-test analysis described by Bouwer and Rice (1976) was judged to be more representative of field conditions than that by Cooper and others (1967), because the Bouwer and Rice method applies to unconfined aquifers with partially penetrating wells and short screens. The lowest value of hydraulic conductivity $(0.8 \mathrm{ft} / \mathrm{d})$ was determined from analysis of a test conducted in well WC 86. This well is screened in fine deposits that are present in the valley bottom of the study area (fig. 3). The highest calculated hydraulic conductivity $(21 \mathrm{ft} / \mathrm{d})$ was in WC 88 , which is screened in fine sand with medium to coarse sand. The median horizontal hydraulic conductivity of wells screened in glacial stratified deposits, excluding well WC 86 (screened in fine deposits), is $6.8 \mathrm{ft} / \mathrm{d}$. These values are in the range of those reported by Mazzaferro and others (1979) for glacial stratified deposits with a median particle diameter of very fine to fine sand. The glacial stratified deposits in the study area may contain a large percentage of fine material in the matrix.

One test was conducted in well WC 84 screened in glacial till. The calculated hydraulic conductivity for the screened part of this well was $2.7 \mathrm{ft} / \mathrm{d}$. This value is the same as the median value reported by Randall and others (1988) for surface tills derived from crystalline bedrock. Horizontal hydraulic conductivity of glacial tills derived from crystalline rocks are reported by Melvin and others (1992 a, b) to generally range from $4 \times 10^{-2}$ to $24 \mathrm{ft} / \mathrm{d}$. 


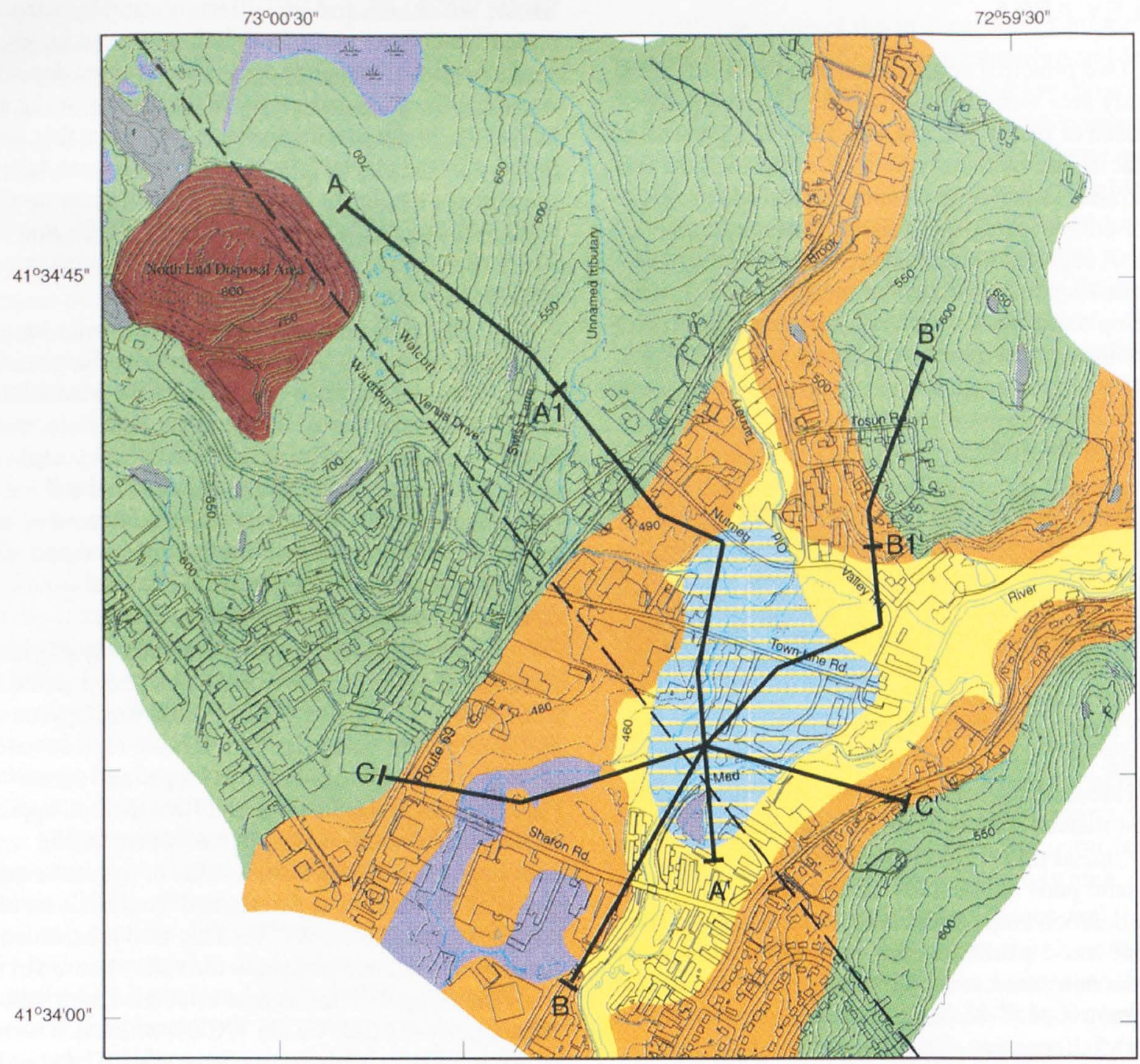

Base from U.S. Army Corps of Engineers, 1993, 1997 Scale $1: 2,400$

Projection: State Plane Feet, Zone 3526

Geology modifed from Stone and others, 1992

Land Surface Contour Interval 10 feet

$\begin{array}{llllllll}0 & 400 & 800 & 1200 & 1600 & 2000 & \text { FEET } \\ 0 & 100 & 200 & 300 & 400 & 500 & \text { METERS }\end{array}$

Figure 3. Distribution of surficial deposits, Nutmeg Valley study area, Wolcott and Waterbury, Connecticut. 


\section{EXPLANATION}

\section{POSTGLACIAL DEPOSITS}

ARTIFICIAL FILL--Shown only at North End Disposal Area. Smaller areas of fill are present throughout the Nutmeg Valley study area. Small areas of artificial fill shown in figure $4 \mathrm{a}$

ALLUVIUM OVERLYING SAND AND GRAVEL--Sand, gravel, silt, and some organic material, on the flood plains of modern streams; overlies glacial sand and gravel described below.

ALLUVIUM OVERLYING FINE DEPOSITS OVERLYING SAND AND GRAVEL--Alluvium overlying fine deposits and sand and gravel described below.

SWAMP--Muck and peat that contain minor amounts of sand, silt, and clay, accumulated in poorly drained areas. Generally less than 10 feet thick.

\section{GLACIAL MELTWATER DEPOSITS}

All sorted and stratified sediments composed of gravel, sand, silt and clay laid down by flowing meltwater during retreat of the last ice sheet; includes minor lenses of flowtill and other diamict sediments.

FINE DEPOSITS--Composed of fine sand, silt and clay particles generally in well sorted, thin layers of alternating silt and clay and (or) very fine sand; locally may contain lenses of coarser material. Fines, if present, overly sand and gravel described below.

SAND AND GR AVEL--Composed of mixtures of gravel and sand within individual layers and as alternating layers. Sand and gravel layers generally range from 25 to 50 percent gravel particles and from 50-75 percent sand particles, Unit contains zones locally that are entirely sand (Shown in figure $4 \mathrm{~b}$.)

\section{GLACIAL ICE-LAID DEPOSITS}

TILL--Poorly sorted, generally nonstratified mixture of grain sizes ranging from clay to large boulders; the matrix of most tills is composed dominantly of sand and silt.

BEDROCK

TAINE MOUNTAIN FORMATION--Bedrock Outcrops

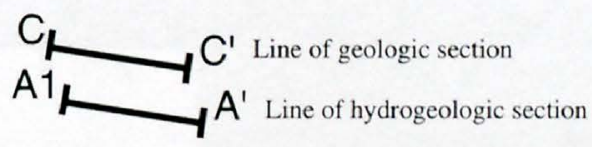

Figure 3. Distribution of surficial deposits, Nutmeg Valley study area, Wolcott and Waterbury, Connecticut--Continued 


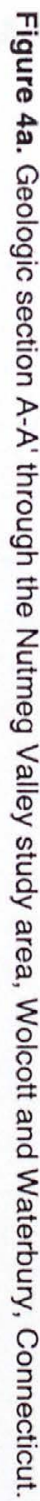

Altitude, in feet above sea level

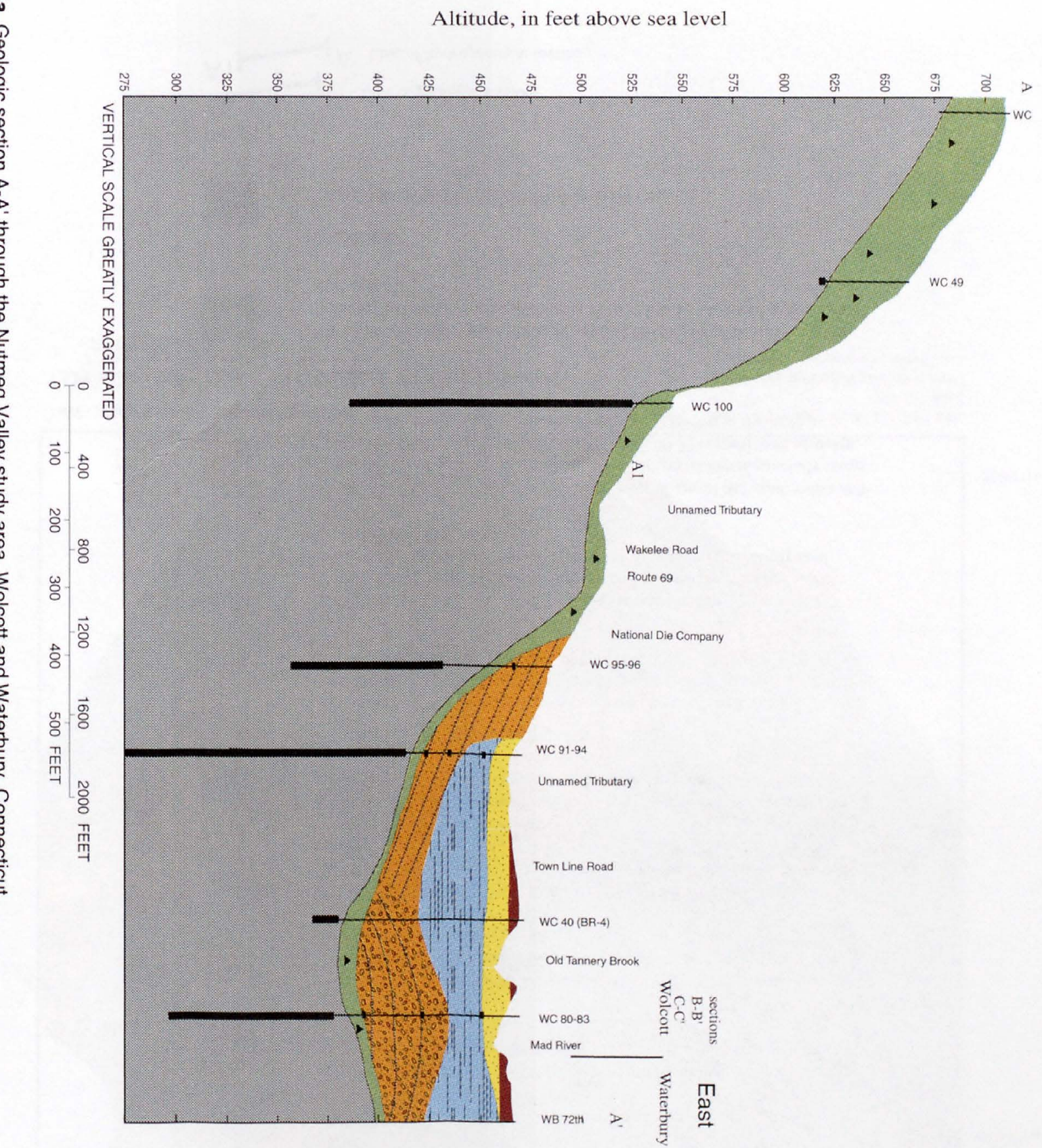




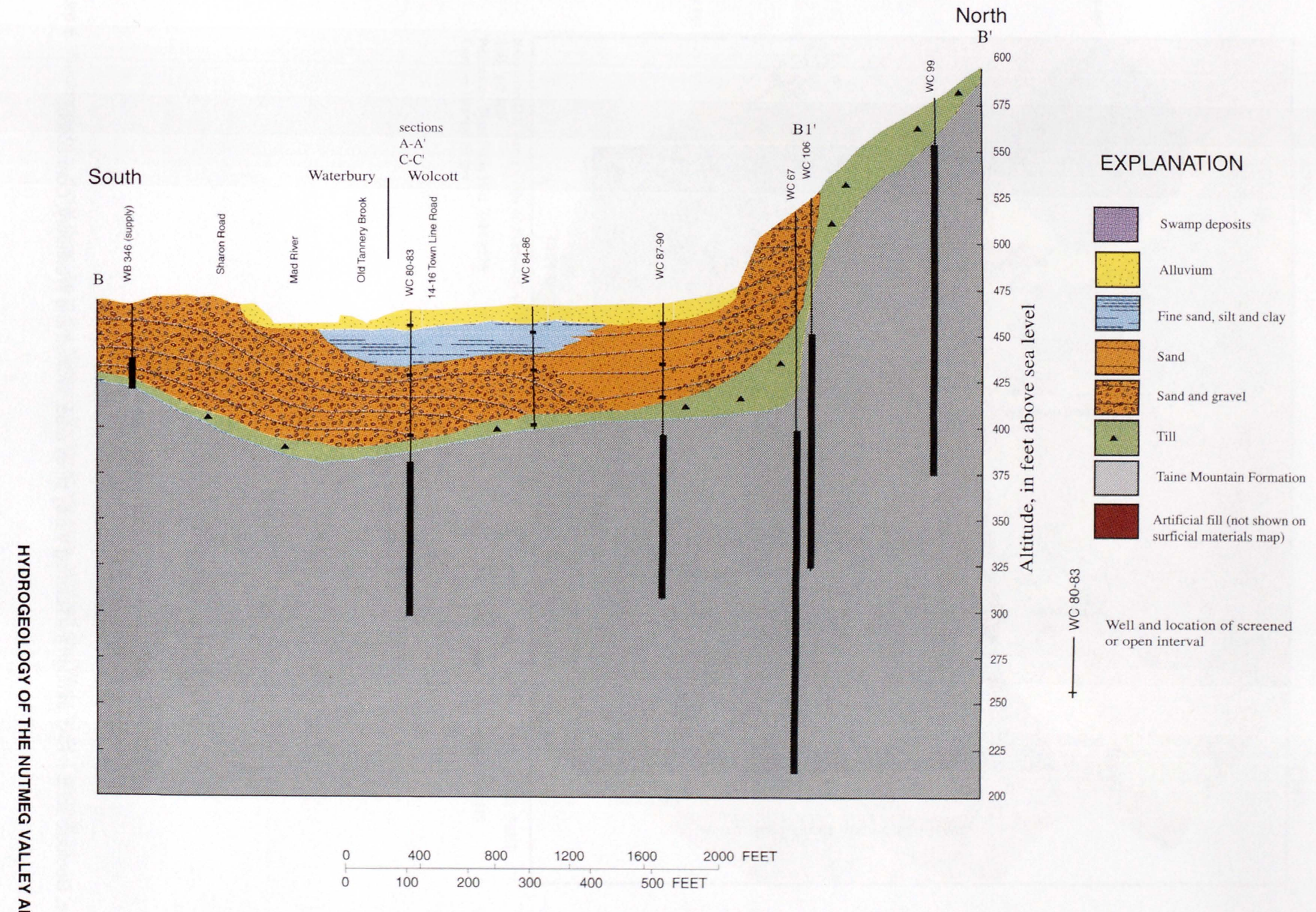

Figure 4b. Geologic section B-B' through the Nutmeg Valley study area, Wolcott and Waterbury, Connecticut. 


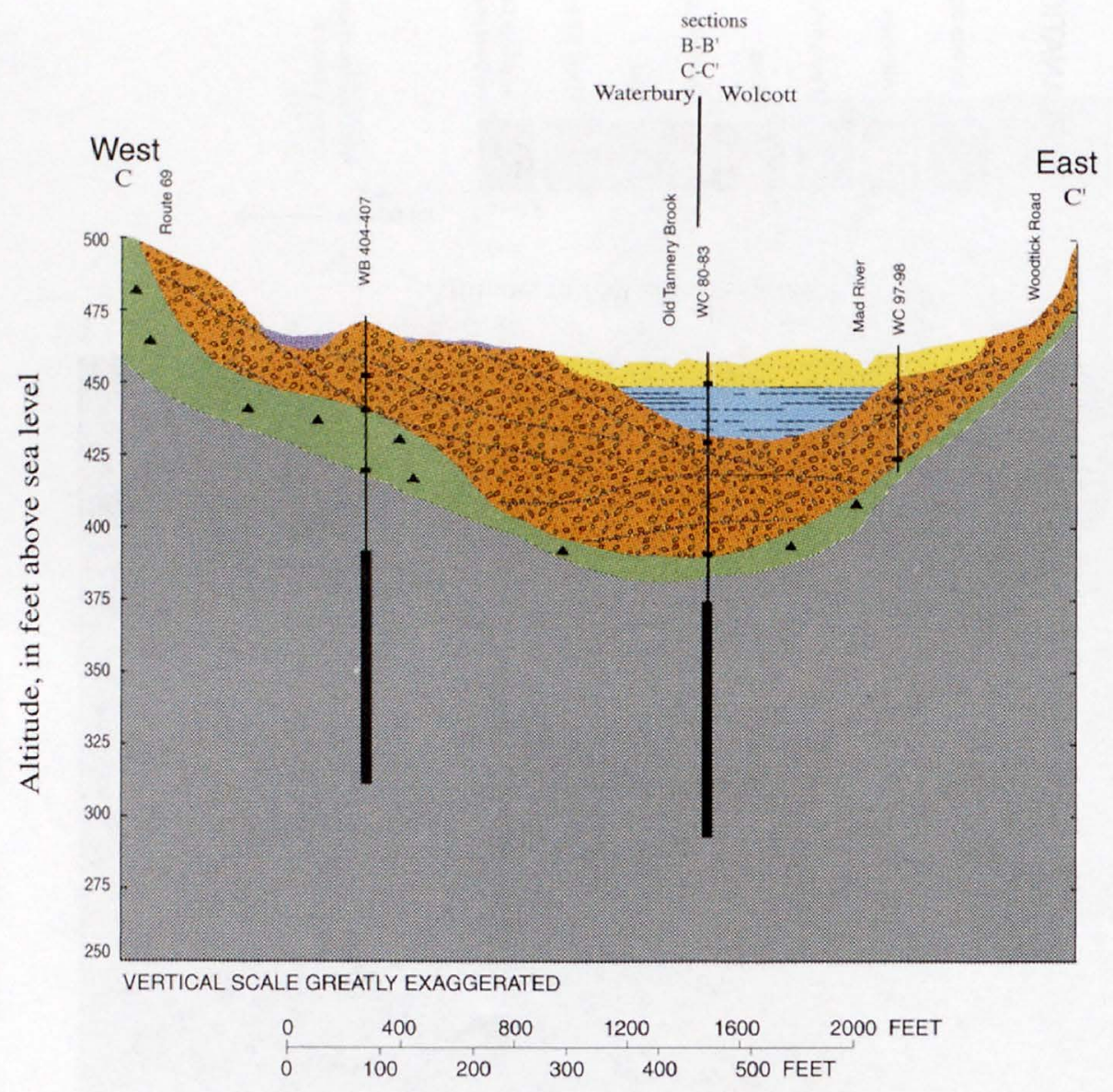

Figure 4c. Geologic section C-C' through the Nutmeg Valley study area, Wolcott and Waterbury, Connecticut. 


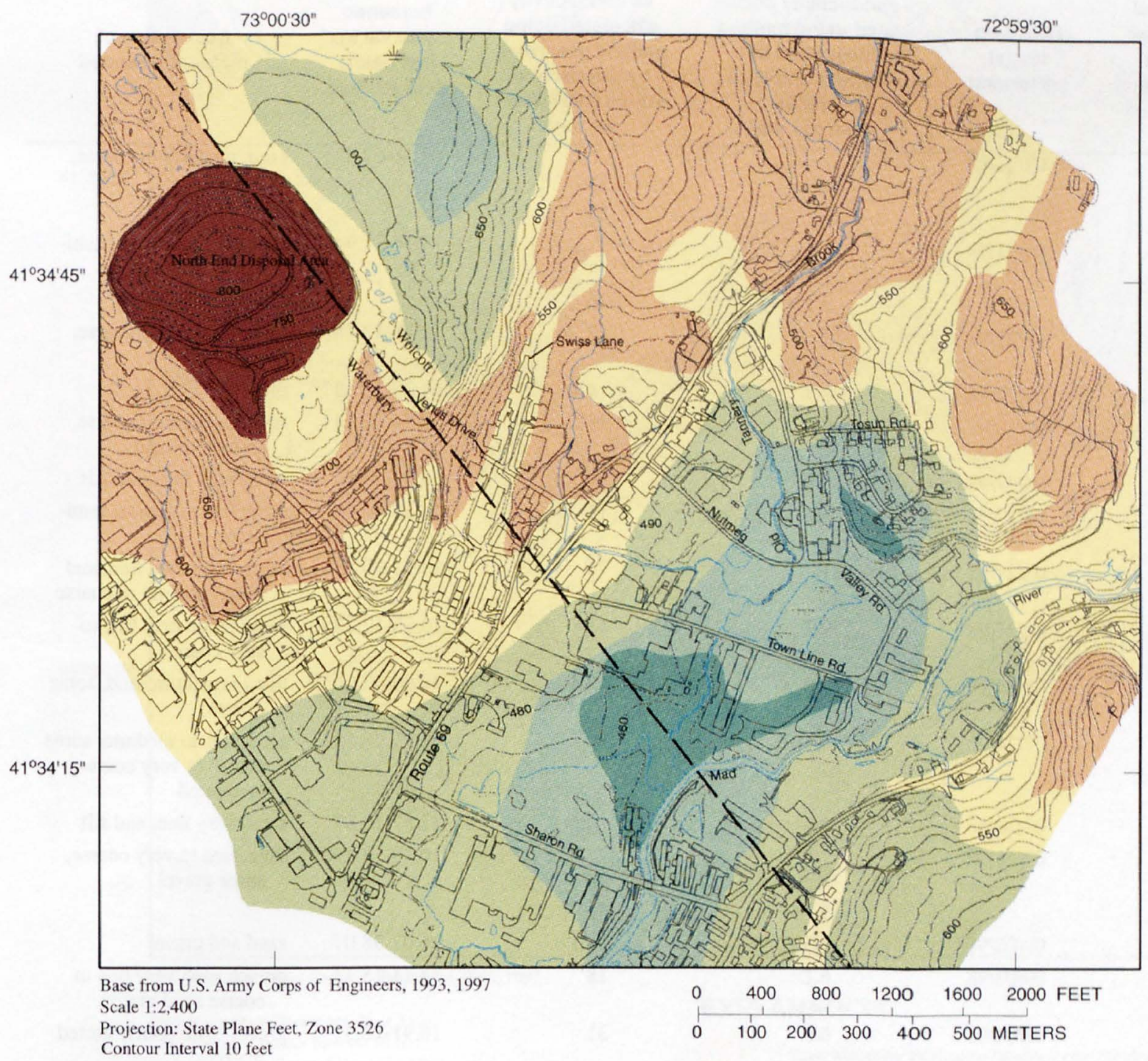

\section{EXPLANATION}

Thickness of surficial materials in feet

\begin{tabular}{|c|}
\hline $0-10$ \\
\hline $10-25$ \\
\hline $25-50$ \\
\hline $50-75$ \\
\hline$>75$ \\
\hline Artifici: \\
\hline
\end{tabular}

Figure 5. Thickness of surficial deposits in the Nutmeg Valley study area, Wolcott and Waterbury, Connecticut. 
Table 3. Hydraulic conductivity of surficial deposits estimated from slug-test analysis, Nutmeg Valley study area, Wolcott and Waterbury, Connecticut

\begin{tabular}{|c|c|c|c|c|c|}
\hline $\begin{array}{c}\text { USGS local } \\
\text { well number } \\
\text { (location } \\
\text { shown on } \\
\text { pl. 1) }\end{array}$ & $\begin{array}{l}\text { Date slug } \\
\text { test(s) } \\
\text { performed }\end{array}$ & $\begin{array}{l}\text { Horizontal hydraulic } \\
\text { conductivity calcu- } \\
\text { lated using method } \\
\text { described by } \\
\text { Bouwer and Rice } \\
\text { (1976) } \\
\text { (feet per day) }\end{array}$ & $\begin{array}{l}\text { Horizontal hydrau- } \\
\text { lic conductivity } \\
\text { calculated using } \\
\text { method described } \\
\text { by Cooper and } \\
\text { others (1967) (feet } \\
\text { per day) }\end{array}$ & $\begin{array}{l}\text { Screened } \\
\text { interval in } \\
\text { feet below } \\
\text { land surface }\end{array}$ & $\begin{array}{l}\text { Description of } \\
\text { material screened }\end{array}$ \\
\hline $\begin{array}{l}\text { WC } 80 \\
\text { test } 1 \\
\text { test } 2\end{array}$ & $07 / 21 / 98$ & $\begin{array}{l}15 \\
13\end{array}$ & $\begin{array}{l}53 \\
53\end{array}$ & $65.48-67.48$ & $\begin{array}{l}\text { sand, medium to coarse, } \\
\text { some gravel }\end{array}$ \\
\hline $\begin{array}{l}\text { WC } 81 \\
\text { test } 1 \\
\text { test } 2\end{array}$ & $07 / 21 / 98$ & $\begin{array}{l}2.7 \\
3.1\end{array}$ & $\begin{array}{l}13 \\
16\end{array}$ & $37.94-39.94$ & $\begin{array}{l}\text { sand, fine to coarse, lami- } \\
\text { nated }\end{array}$ \\
\hline WC 82 & $07 / 21 / 98$ & 17 & 72 & $10.18-12.18$ & $\begin{array}{l}\text { sand, medium to coarse, } \\
\text { well sorted }\end{array}$ \\
\hline WC 84 & $08 / 27 / 98$ & 2.7 & 4.1 & $64.38-66.38$ & till \\
\hline WC 85 & $09 / 10 / 98$ & 8.3 & 31 & $35.94-37.94$ & $\begin{array}{l}\text { sand, medium to coarse, } \\
\text { some fine sand }\end{array}$ \\
\hline WC 86 & $08 / 27 / 98$ & 0.8 & 0.3 & $14.57-16.57$ & sand, very fine, and silt \\
\hline WC 87 & $08 / 27 / 98$ & 5.7 & 11 & $47.86-49.86$ & $\begin{array}{l}\text { sand, fine to coarse, lami- } \\
\text { nated }\end{array}$ \\
\hline WC 88 & $08 / 27 / 98$ & 21 & 74 & $28.53-30.53$ & $\begin{array}{l}\text { sand, laminated fine, and } \\
\text { sand, medium to coarse }\end{array}$ \\
\hline WC 89 & $08 / 27 / 98$ & 9.2 & 41 & $10.23-12.23$ & $\begin{array}{l}\text { sand, laminated, fine to } \\
\text { very coarse }\end{array}$ \\
\hline WC 91 & $07 / 24 / 98$ & 2.6 & 7.4 & $40.06-42.06$ & $\begin{array}{l}\text { fine to medium sand, some } \\
\text { gravel }\end{array}$ \\
\hline WC 92 & 07/24/98 & 9.7 & 31 & $26.55-28.55$ & $\begin{array}{l}\text { sand, fine to medium, some } \\
\text { coarse to very coarse, } \\
\text { laminated }\end{array}$ \\
\hline WC 93 & 07/24/98 & 2.6 & 0.6 & $11.57-13.57$ & sand, very fine, and silt \\
\hline $\begin{array}{l}\text { WC } 95 \\
\text { test } 1 \\
\text { test } 2\end{array}$ & $07 / 21 / 98$ & $\begin{array}{l}8.2 \\
11\end{array}$ & $\begin{array}{l}46 \\
35\end{array}$ & $16.49-18.49$ & $\begin{array}{l}\text { sand, fine to very coarse, } \\
\text { some gravel }\end{array}$ \\
\hline WC 97 & 09/08/98 & 4.3 & 4.1 & $36.07-38.07$ & sand and gravel \\
\hline WC 98 & 09/08/98 & 6.1 & 18 & $13.14-15.14$ & $\begin{array}{l}\text { gravel, with very fine to } \\
\text { coarse sand matrix }\end{array}$ \\
\hline WB 406 & 08/04/98 & 6.8 & 31 & $16.91-18.91$ & $\begin{array}{l}\text { gravel, with poorly sorted } \\
\text { matrix }\end{array}$ \\
\hline
\end{tabular}

\section{Bedrock aquifer}

Bedrock in the study area consists of several lithologic types in the Taine Mountain Formation (Rodgers, 1985); these include well-foliated gneiss, granofels, and local pegmatite sills. Orientations of layering and fractures in these rock types were measured at four outcrops (numbered 1-4 in fig. 6). Strike and dip of foliation measured at the bedrock outcrops ranges from NNW strike (azimuth $320-345^{\circ}$ ) with near vertical dip at outcrop 1 , to $\mathrm{N}$ strike (azimuth $5^{\circ}$ ) with $\mathrm{E}$ dip of $55^{\circ}$ at outcrop 2, to NNE strike (azimuth $40^{\circ}$ ) with SE dip of $40^{\circ}$ at outcrop 4 . Some fractures are parallel to foliation at the outcrops.

Lithologic differences in the subsurface bedrock are discernible on the BIPS logs from the bedrock wells (fig. 7). Well-foliated gneiss is the predominant rock type in the stratigraphic sections penetrated by the seven bedrock wells in which borehole logs were collected. In most wells, the foliation strikes north with an easterly dip of approximately $50-60^{\circ}$. 


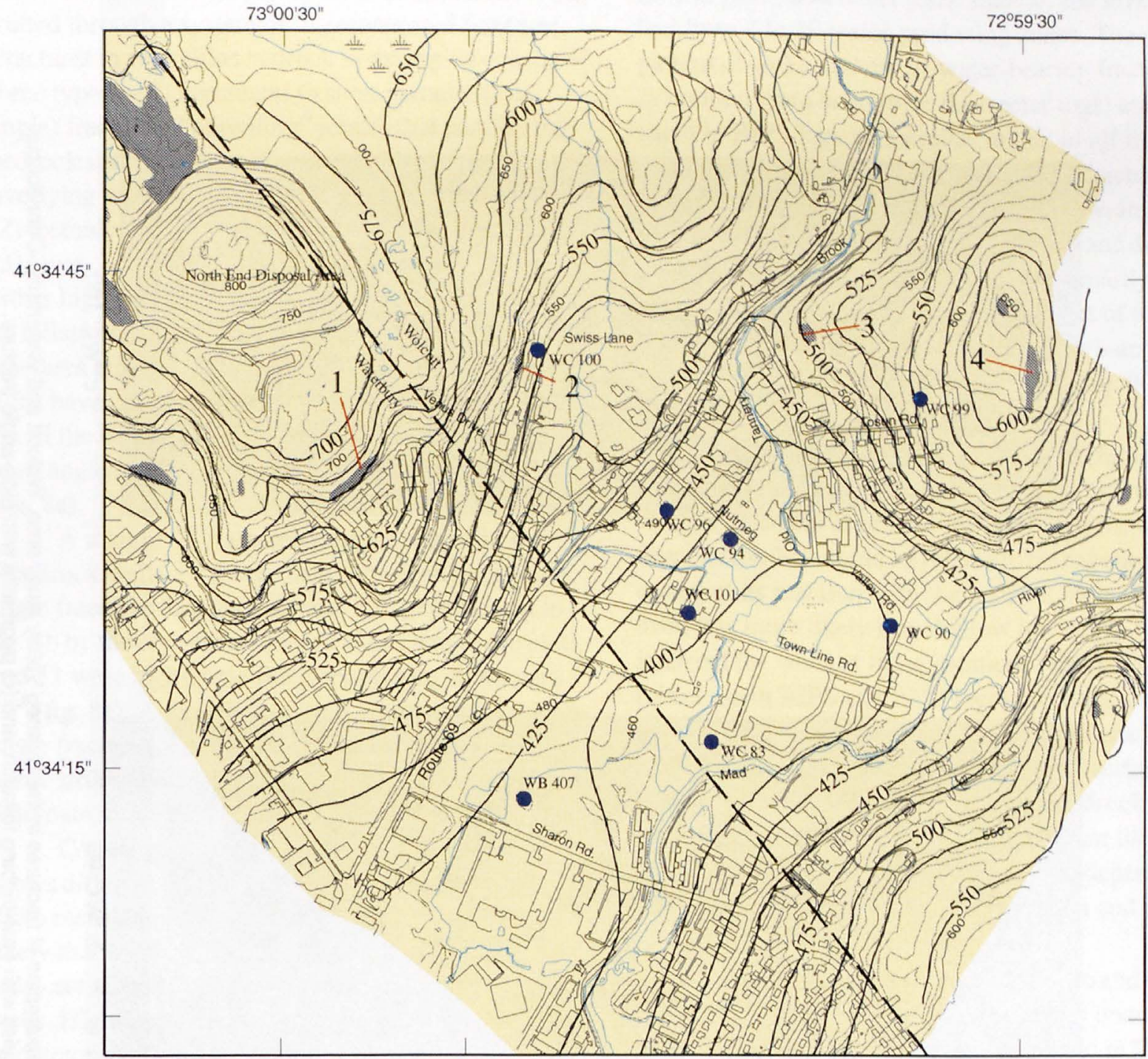

Base from U.S. Army Corps of Engineers, 1993, $199^{\circ}$

Scale 1:2,400

Projection: State Plane Feet, Zone 3526

Land Surface Contour Interval 10 feet

Bedrock Surface Contour Interval 25 feet

\begin{tabular}{cccccccc}
0 & 400 & 800 & 1200 & 1600 & 2000 & FEET \\
\hline 0 & 100 & 200 & 300 & 400 & 500 & METERS
\end{tabular}

EXPLANATION

aine Mountain Formation (Bedrock type not shown outside of study area

Bedrock outcrops where fracture orientation measured and reference number

500 Bedrock surface contour and altitude

WB 407 Well where borehole geophysical measurements made

Figure 6. Bedrock-surface altitudes, location of bedrock outcrops, and location of bedrock wells in which fracture orientations and flow measurements were made, Nutmeg Valley study area, Wolcott and Waterbury, Connecticut. 


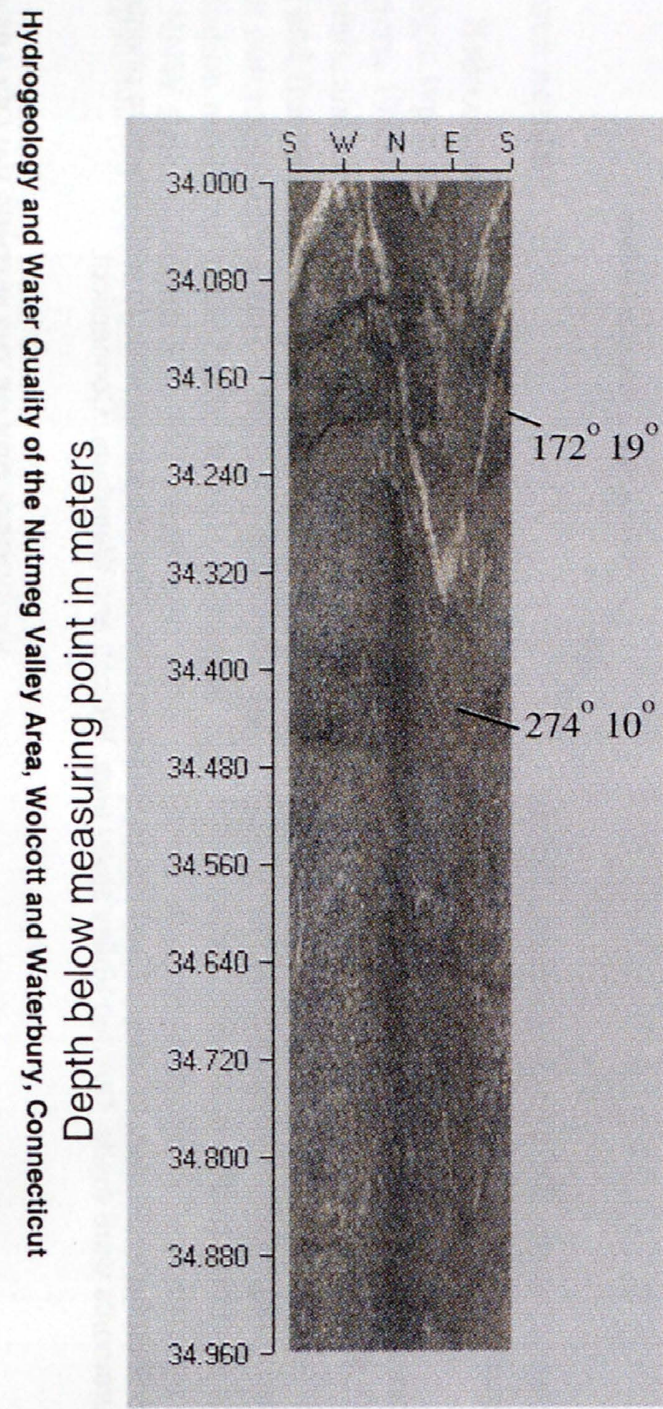

a. WB 407

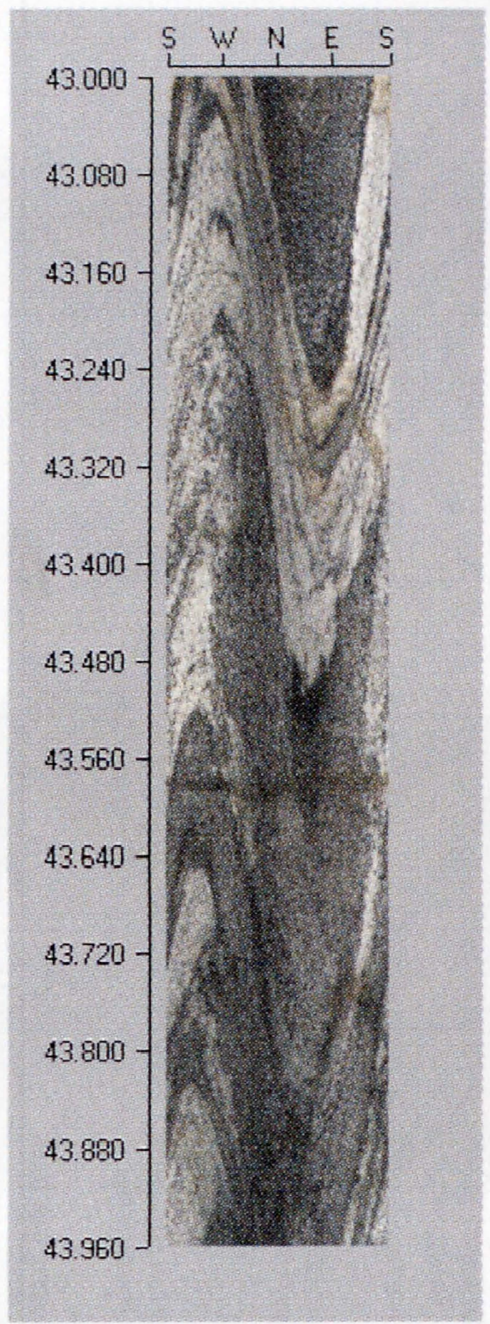

b. WC 90

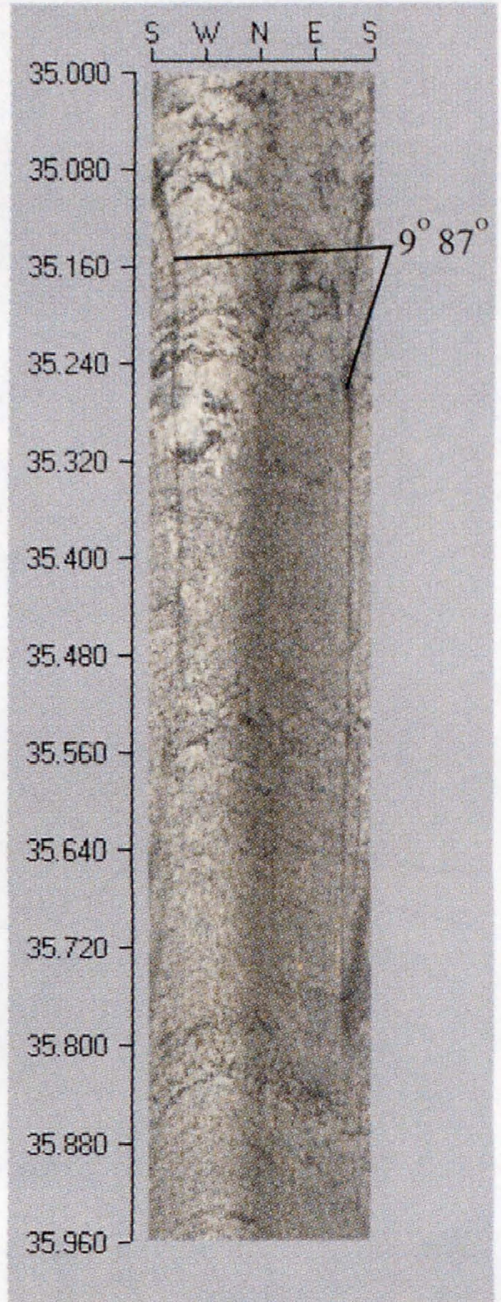

c. WC 100

Figure 7. Borehole images showing different rock types and examples of fractures in the Nutmeg Valley study area, Wolcott and Waterbury, Connecticut. (a) nonlayered granofels with east-dipping quartz vein, (b) gneiss with east-dipping foliation, and (c) pegmatite with high-angle fracture. [Measurements of dip direction and dip angle shown; ${ }^{\circ}$, degrees] 
In the bedrock aquifer, water is stored and transmitted through a system of interconnected fractures. Fractures in crystalline bedrock in the region consist of three types-(1) horizontal to subhorizontal (lowangle) fractures ("unroofing" joints) that parallel the bedrock surface and were generated by removal of overlying rock by erosion over geologic time;

(2) tectonically generated high-angle fractures; and (3) layer- or foliation-parallel fractures that may be either high- or low-angle depending on the orientation of foliation in the particular area. All three types of fractures are present in the study area and their orientations have been measured at bedrock outcrops and in six of the seven bedrock wells. Northwest-striking high-angle fractures predominate at the outcrops (fig. 8a).

A total of 98 fractures were measured in the 6 bedrock wells -47 were nearly horizontal or lowangle fractures dipping less than $45^{\circ}$ (represented in fig. 8 b by the concentration near the center of the plot), and 51 were high-angle fractures dipping more than $45^{\circ}$ (fig. 8c). Although preferred orientations for highangle fractures differ somewhat from well to well, north-striking, east-dipping, high-angle fractures predominate in the bedrock wells (fig. 8c).

Comparison of figures $8 \mathrm{a}$ with $8 \mathrm{~b}$ and $8 \mathrm{~d}$ with $8 \mathrm{e}$ shows different fracture sets measured at outcrops from those measured in the bedrock wells; however, it is likely that bedrock-fracture orientations in outcrop areas are actually similar to those in areas of bedrock wells. High-angle fractures are preferentially exposed in outcrops, which have large horizontal and small vertical extent (fig. 8a). Conversely, in wells, high-angle fractures are less frequently intercepted by the vertical well bore and low-angle fractures are preferentially sampled (fig. 8b). Another reason for the difference in fracture sets measured is that the vertical outcrop faces in the study area are generally aligned N-S and do not expose the predominant set of north-striking fractures measured in the bedrock wells (figs. $8 \mathrm{~d}$ and $8 \mathrm{e}$ ).

Water-producing fracture zones, defined by increases in flow of at least $0.01 \mathrm{gal} / \mathrm{min}$ between measurements, were identified in seven wells with the use of heat-pulse flowmeter tests. Each of the seven wells had from 4 to 10 water-producing zones. The general pattern of strike and dip of water-bearing fractures (identified from heat-pulse flowmeter $\log$ s) and measured in BIPS logs was similar to that of all fractures measured (fig. 9a). These water-bearing fractures include 19 high-angle fractures and 25 low-angle (less than or equal to $45^{\circ}$ ) fractures. The strike and dip of the high-angle water-bearing fractures is primarily to the north and east respectively, similar to that of the foliation measured in outcrops. Secondary high-angle water-bearing fractures strike northeast (fig. 9c) and dip to the northwest.

Heat-pulse flowmeter information (fig. 10) indicates that in some wells, most of the water comes from shallow fractures at or near the bottom of the casing. Some of the flow could be related to leakage around the casing at its junction with the bedrock surface; however, it is more likely that shallow low-angle fractures intersect the wells at these locations. These fractures (observed in BIPS and ATV logs) probably are in connection with the surficial aquifers through nearby highangle fractures that intersect the bedrock surface.

Ground-water movement between the bedrock and the surficial aquifers and contaminant transport likely take place through these high-angle fractures, depending on location in the ground-water-flow system and rates of ground-water withdrawal.

At least two wells (including WC 96 and WC 94) had ground-water flow between fractures under nonpumping conditions. Flow was downward in WC 96 and upward in WC 94. The static flow that took place at these locations was caused by differences in hydraulic head between fracture zones. The gradients are probably natural in these cases, because no pumping effects were observed in pressure-transducer data collected from these wells. The heat-pulse flowmeter data for these wells show that bedrock wells can provide short-circuit pathways between fracture zones; this may have caused or facilitated vertical transport of VOCs in the bedrock aquifer in the study area in the past. 


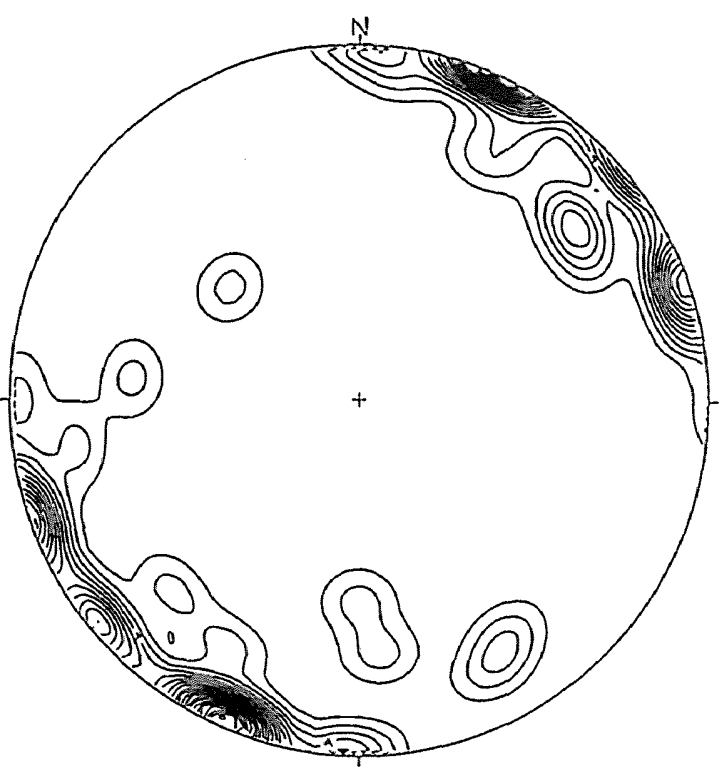

a. Fractures measured at outcrops $n=40$

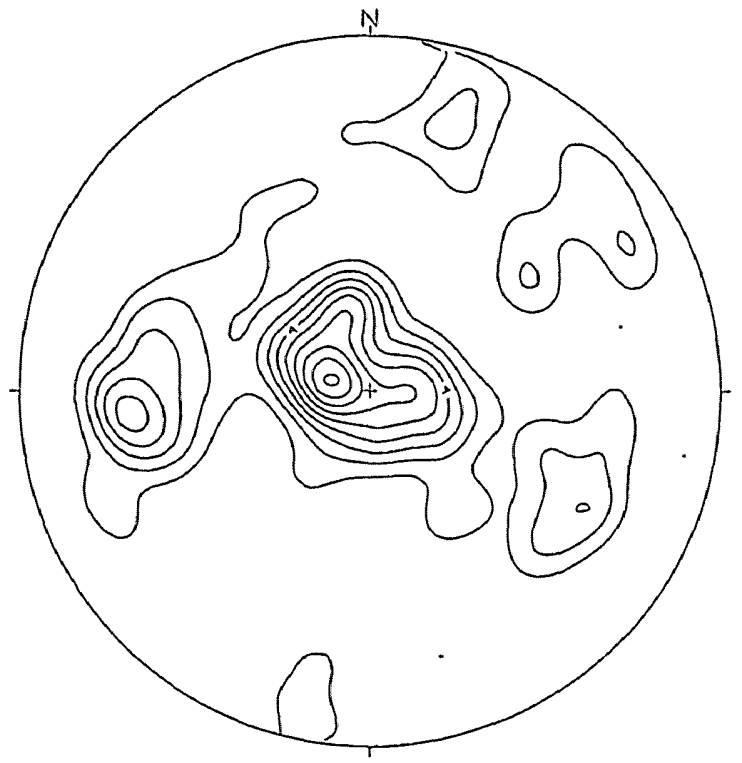

b. All subsurface fractures measured in wells $n=98$

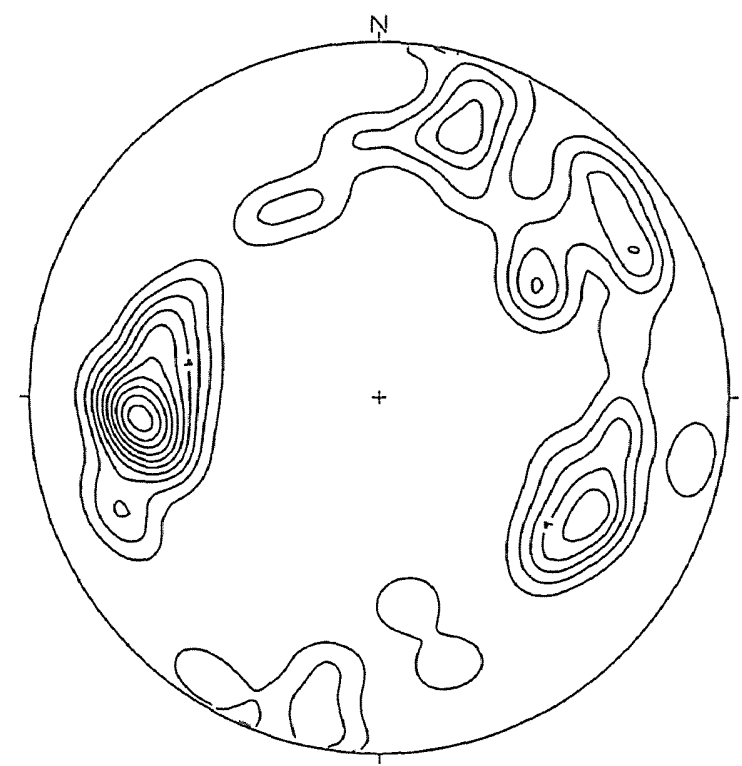

c. High-angle subsurface fractures measured in wells $n=51$

Lower-hemisphere equal-area-net plots of contoured poles to fracture planes. Density contour interval 1, labeling interval 4.

Figure 8. Orientation of fracture planes measured in outcrops and bedrock wells, Wolcott and Waterbury, Connecticut. 


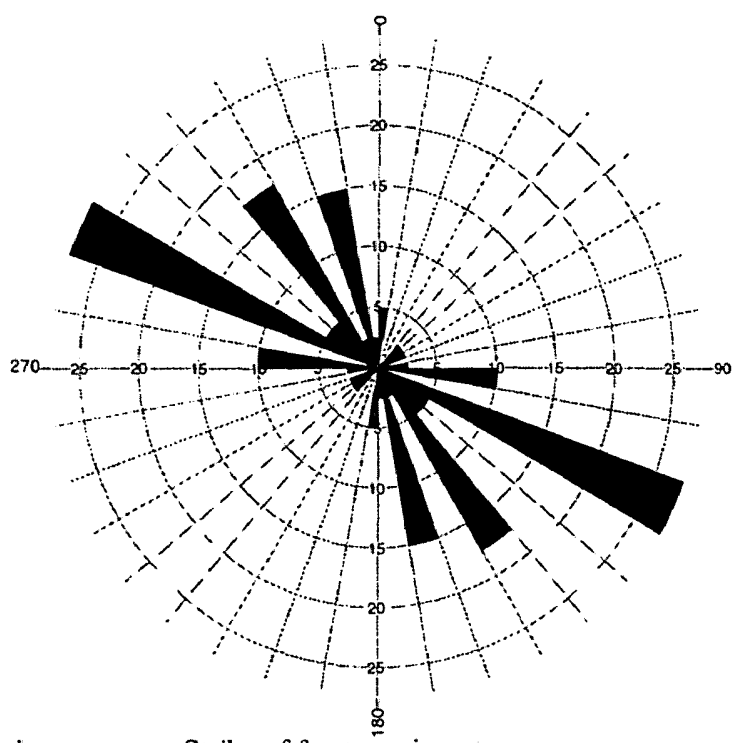

d.

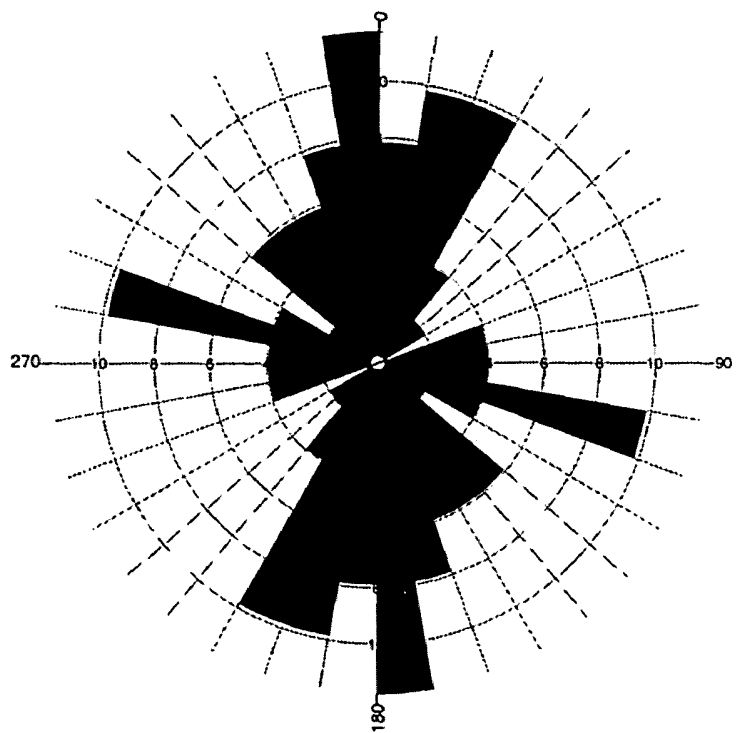

e.

Strike of high-angle subsurface fractures

$\mathrm{n}=40$

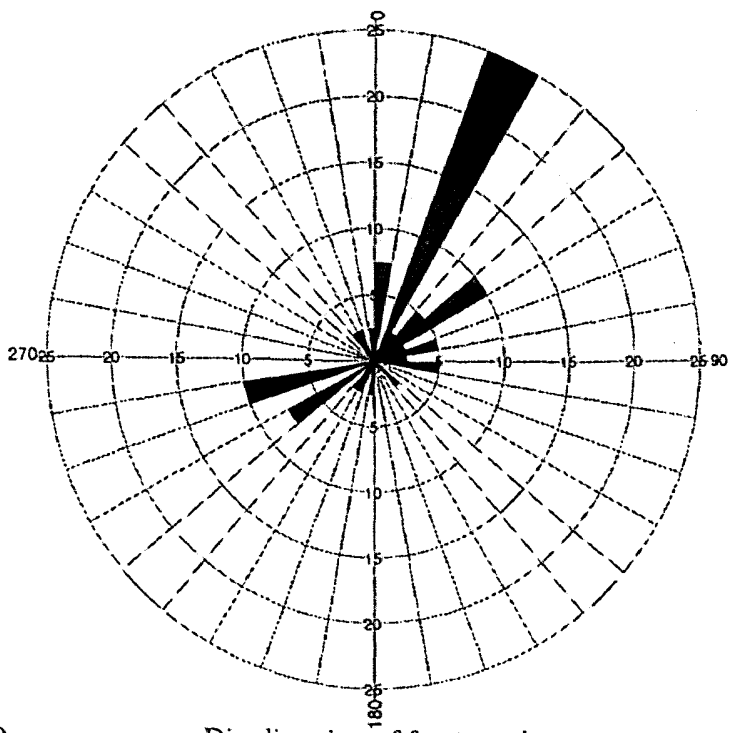

Dip direction of fractures in outcrops

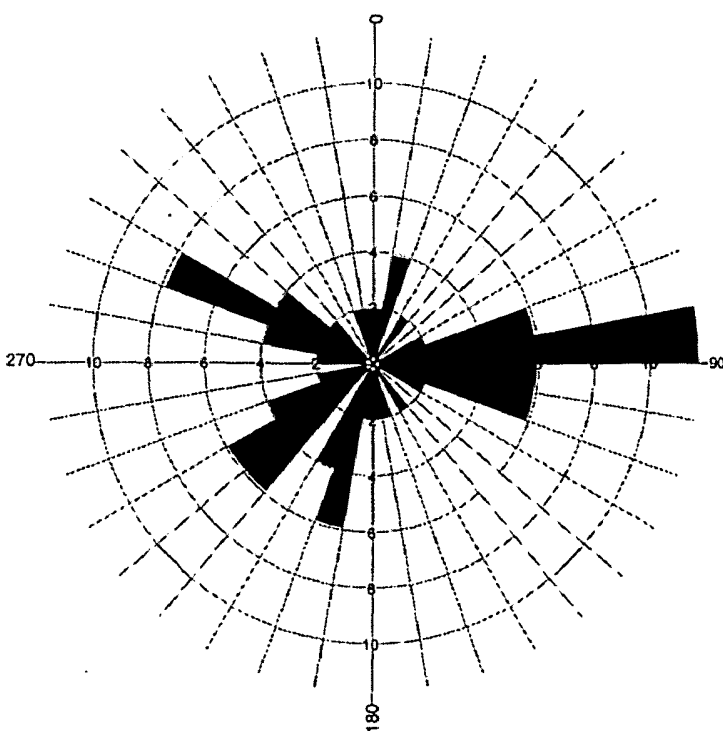

Dip direction of high-angle subsurface fractures

Rose diagrams

Figure 8. Orientation of fracture planes measured in outcrops and bedrock wells, Wolcott and Waterbury, Connecticut-Continued. 


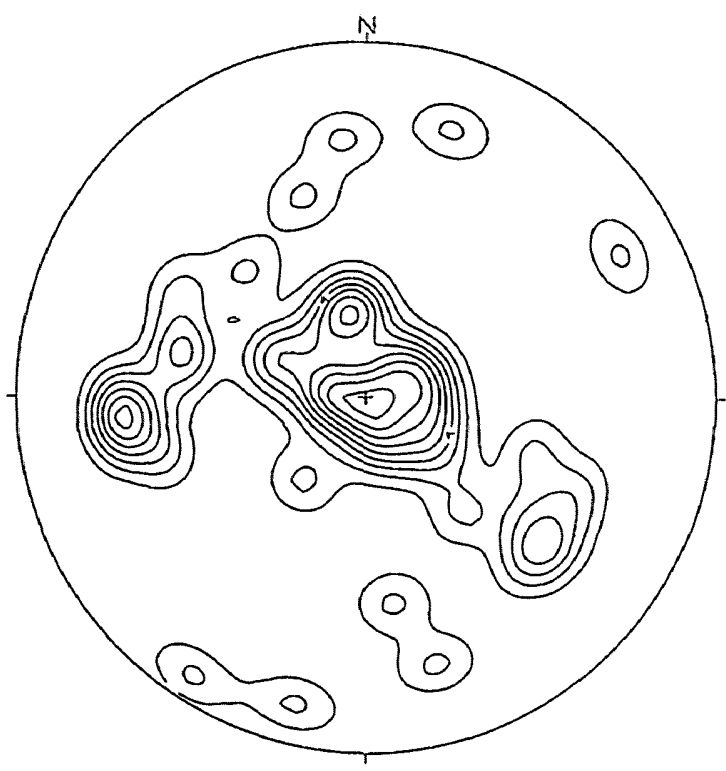

a. Subsurface water-bearing fractures $n=44$

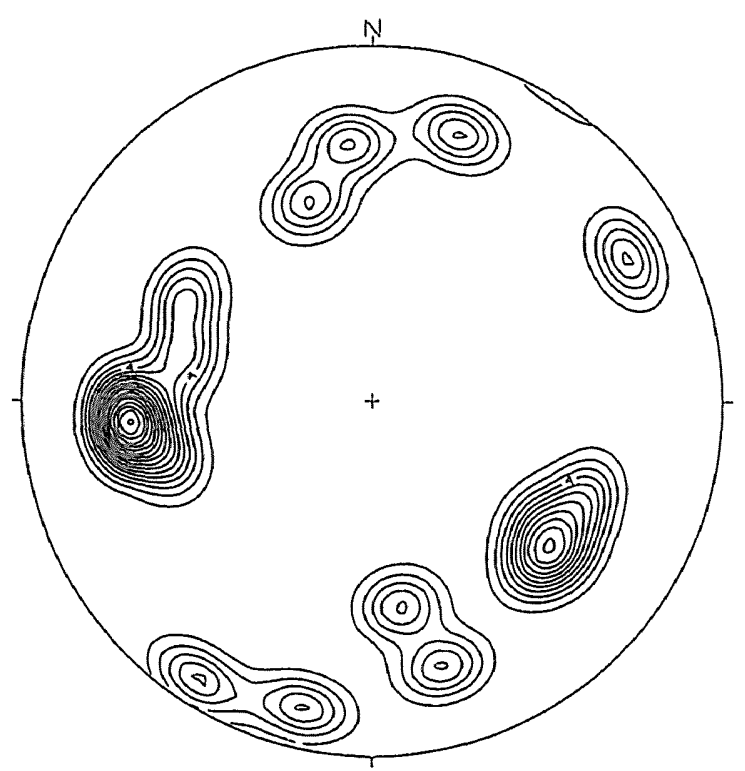

b. Subsurface high-angle water-bearing fractures $\mathrm{N}=19$

Lower-hemisphere equal-area-net plots of contoured poles to fracture planes. Density contour interval 1, labeling interval 4.
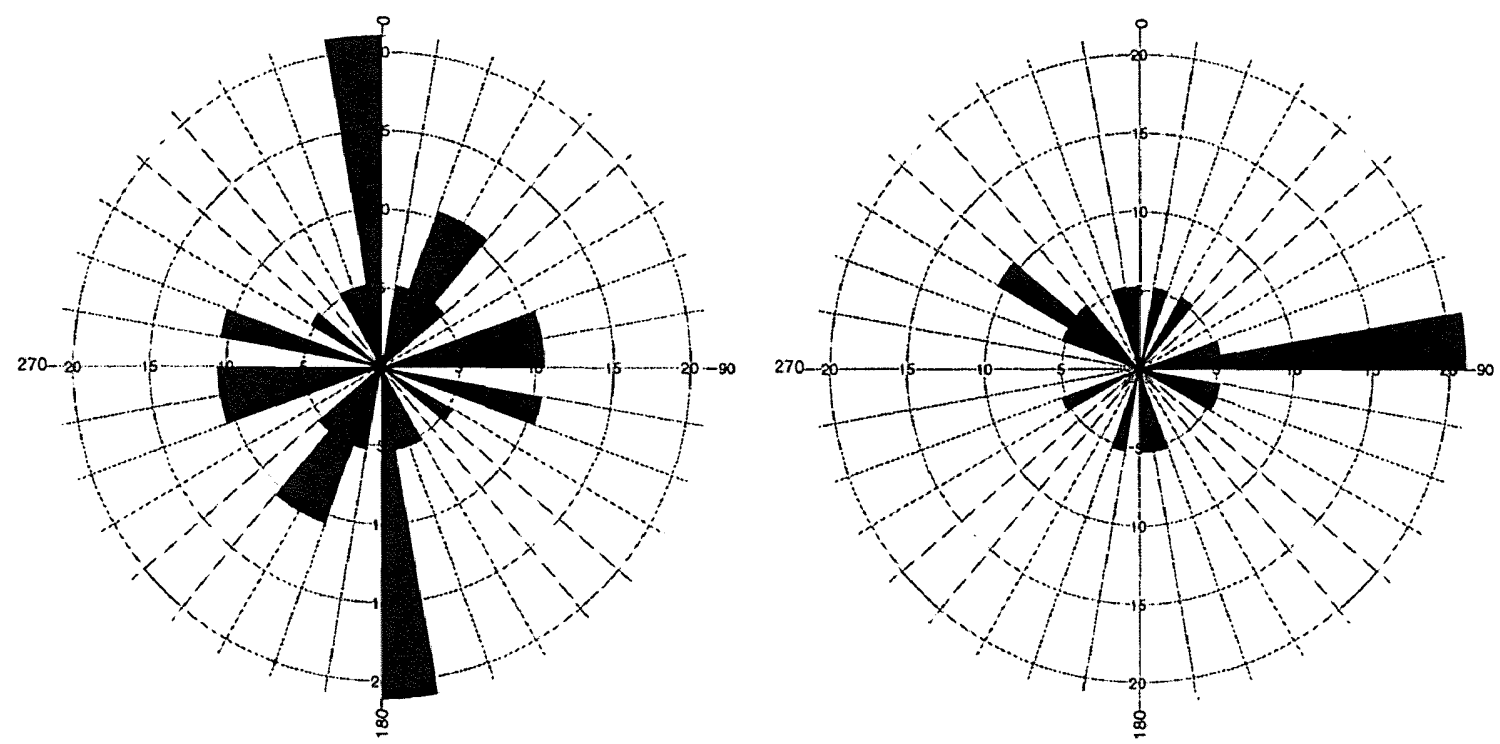

c. Strike of high-angle subsurface water-bearing fractures $n=19$ Dip direction of high-angle water-bearing subsurface fractures

Rose diagrams

Figure 9. Orientation of water-bearing fractures measured in outcrops and bedrock wells, Wolcott and Waterbury, Connecticut. 


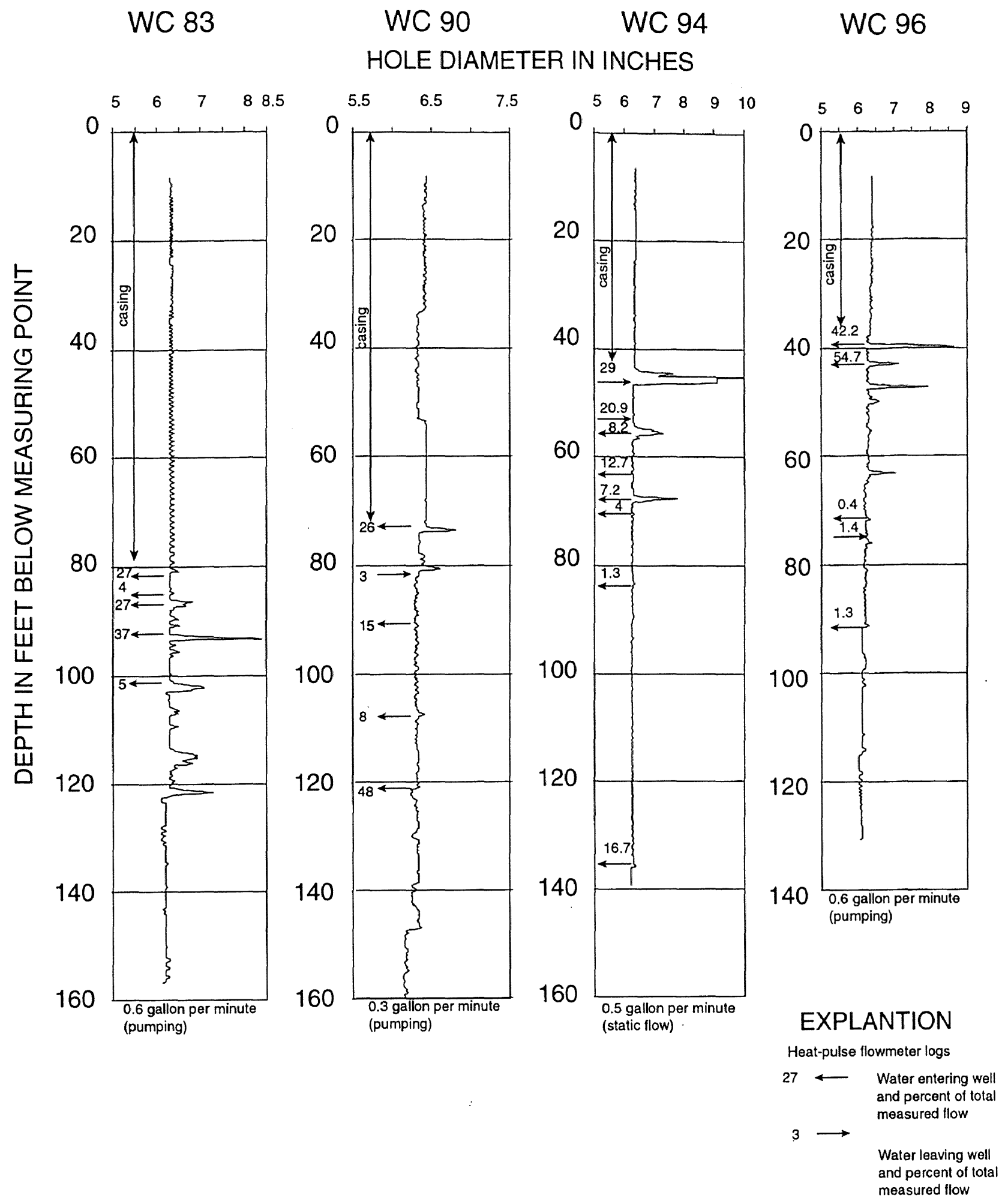

Figure 10. Caliper logs with percentage of flow (from heat-pulse flowmeter tests) in specific water-bearing fractures. 
WC 99

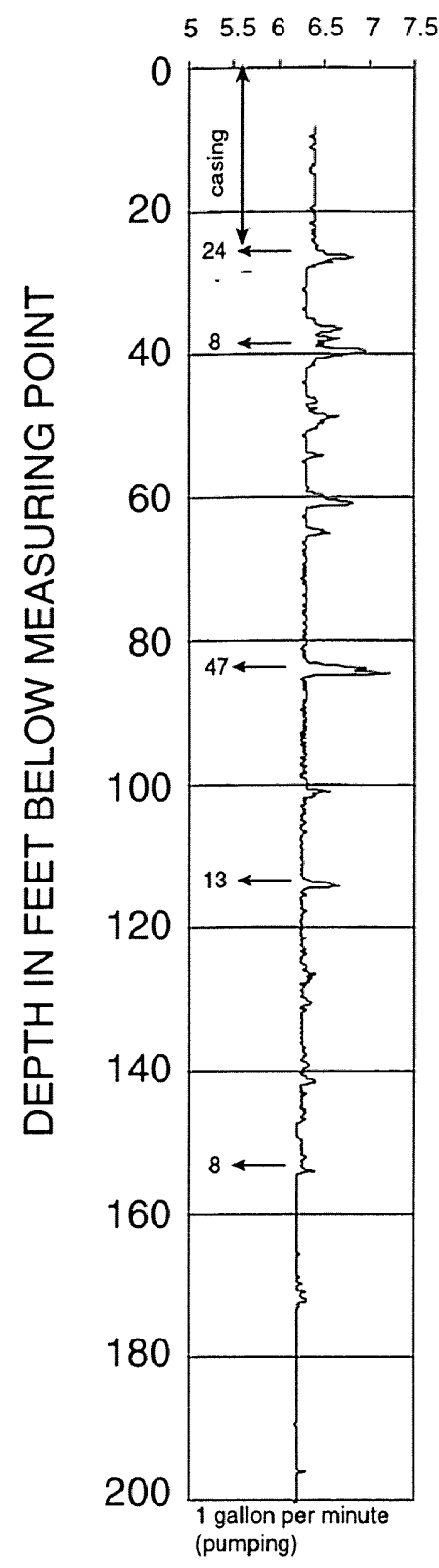

WC 100 HOLE DIAMETER IN INCHES

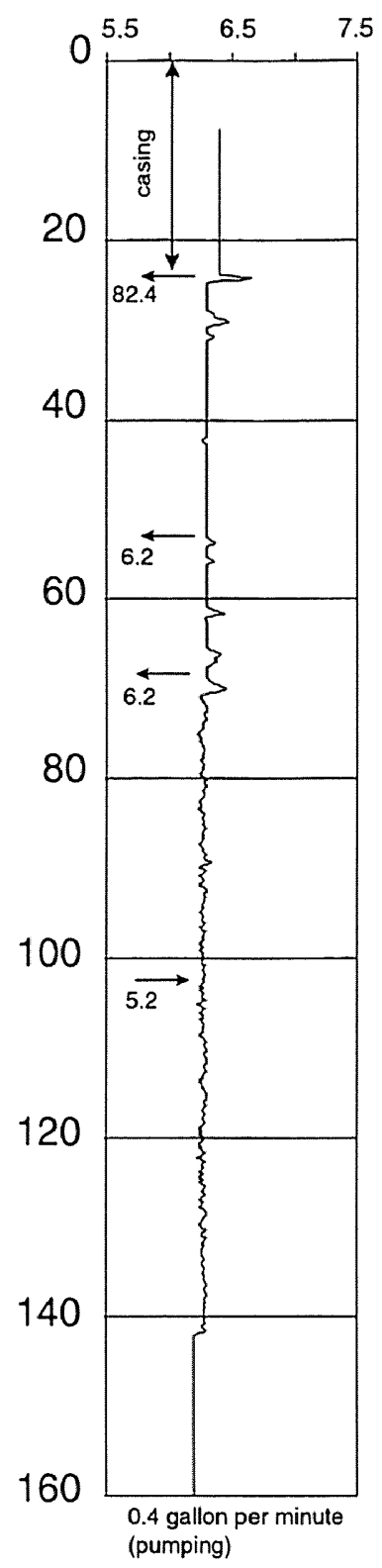

WB 407

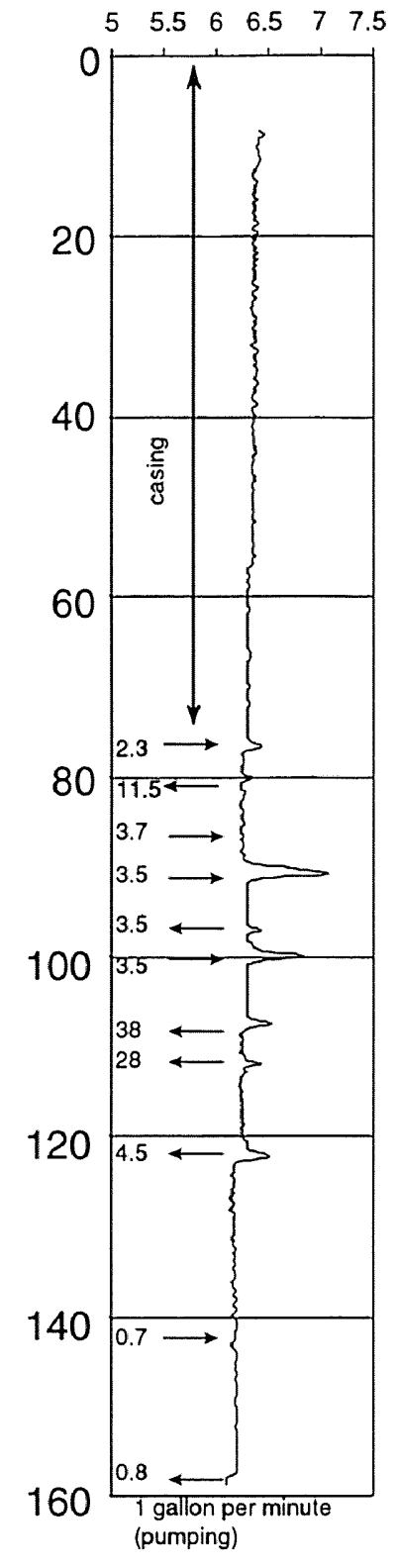

\section{EXPLANTION}

Heat-pulse flowmeter logs

27

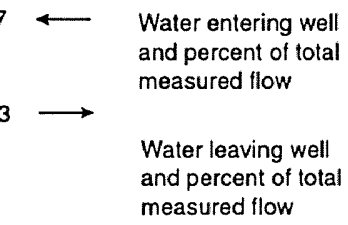

Figure 10. Caliper logs with percentage of flow (from heat-pulse flowmeter tests) in specific water-bearing fractures-Continued. 


\section{Ground-water flow}

Water in the surficial aquifer generally flows toward discharge points along streams in and near the study area (fig. 11). Shallow ground water discharges to Old Tannery Brook from the west, north, and east. Water may discharge at some points on the unnamed tributary to Old Tannery Brook, but it is likely that the water from the stream recharges the ground water in the lower reaches near the confluence with Old Tannery Brook (discussed later in this report). Ground water also discharges to the Mad River. Ground water from beneath the layers of fine-grained sediments may discharge to the Mad River beyond the limits of these semi-confining layers near the area just north of Sharon Rd. Ground-water-flow direction in the stratified glacial deposits may be affected locally by horizontal and vertical variations in hydraulic conductivity.

The general direction of ground-water flow in the bedrock aquifer is downslope from upland areas and southeast in the valley bottom (fig. 12) toward the Mad River, except in the Tosun Rd. residential area, where the general flow direction is to the southwest. The direction of ground-water flow in the bedrock aquifer is likely to be affected locally by the orientation of fractures. Water in the bedrock aquifer flows through high-angle and low-angle fractures; therefore, vertical and horizontal anisotropy may be affecting local flow directions in the bedrock.

\section{Hydraulic gradients and interaction between surficial and bedrock aquifers}

Horizontal hydraulic gradients estimated from water-level measurements made in September 1998 ranged from $0.002 \mathrm{ft} / \mathrm{ft}$ to $0.02 \mathrm{ft} / \mathrm{ft}$ in the glacial stratified aquifer. Locally, steep gradients may be caused by the low hydraulic conductivity of the thick fine-grained deposits in some parts of the site. The horizontal hydraulic gradients are lowest where the fine-grained deposits are thin or absent and materials are generally coarse. Horizontal hydraulic gradients in the surficial till deposits ranged from $0.04 \mathrm{ft} / \mathrm{ft}$ to $0.13 \mathrm{ft} / \mathrm{ft}$. Gradients in the till deposits may be controlled by the steepness of the underlying bedrock surface and variations in hydraulic conductivity. Horizontal hydraulic gradients in the potentiometric surface of the bedrock aquifer ranged from $0.01 \mathrm{ft} / \mathrm{ft}$ in the valley bottom to $0.5 \mathrm{ft} / \mathrm{ft}$ in the Tosun $\mathrm{Rd}$. residential area.

Vertical hydraulic gradients (both upward and downward) were present at some well clusters that had wells in the bedrock and surficial deposits. This indicated the potential for upward ground-water flow from the bedrock to the surficial aquifer at some locations and downward flow in other places. During September 1-3, 1998, water-level measurements indicated that downward gradients from the surficial aquifers to the bedrock aquifers were present at well clusters WC 9596, WC 91-94, WC 87-90, and WC 109-110 (HRP Associates, 1998-MW1, MW2), located primarily in valley bottoms in the northern parts of the study area. These measurements show that the water in the surficial deposits had the potential to recharge the bedrock if a good connection is present between the fractures in the bedrock and the surficial materials. Where downward vertical gradients are present, dissolved contaminants are potentially able to move from the surficial deposits to the bedrock ${ }^{1}$. It is possible that these downward gradients may decrease in dry years, and the boundary between recharge and discharge areas may shift.

The September 1998 measurements also show that upward hydraulic gradients were present at well clusters WB 404-407 and WC 80-83, in the southern part of the study area, close to surface-water bodies. These two well cluster sites represent places where water from the bedrock presumably moves upward into the surficial deposits toward the discharge areas along the Mad River, probably near the southern boundary of the study area. The upward gradient at well cluster WB 404-407 may be caused by nearby pumping (WB 346) of the surficial aquifer for lawn irrigation.

The magnitudes of the vertical hydraulic gradients between the surficial deposits and bedrock were not calculated, because it was beyond the scope of this investigation to determine water levels in specific fractures. Water levels in bedrock wells represent an average of the hydraulic heads in all of the water-bearing fractures. Individual measurements of water levels in isolated water-bearing fractures would be necessary to determine actual vertical hydraulic gradients. Waterlevel altitudes grouped by well cluster for measurements made during 1998 are shown in appendix 3.

\footnotetext{
${ }^{1}$ Several of the VOCs detected (including TCE, PCE, and TCA) in the study area, could have been originally present as dense non-aqueous phase liquids (DNAPLs). DNAPLs can sink in aquifers regardless of vertical hydraulic gradient direction. The sinking of DNAPLs is another possible mechanism of downward transport of contaminants from the surficial aquifer to the bedrock in the study area.
} 

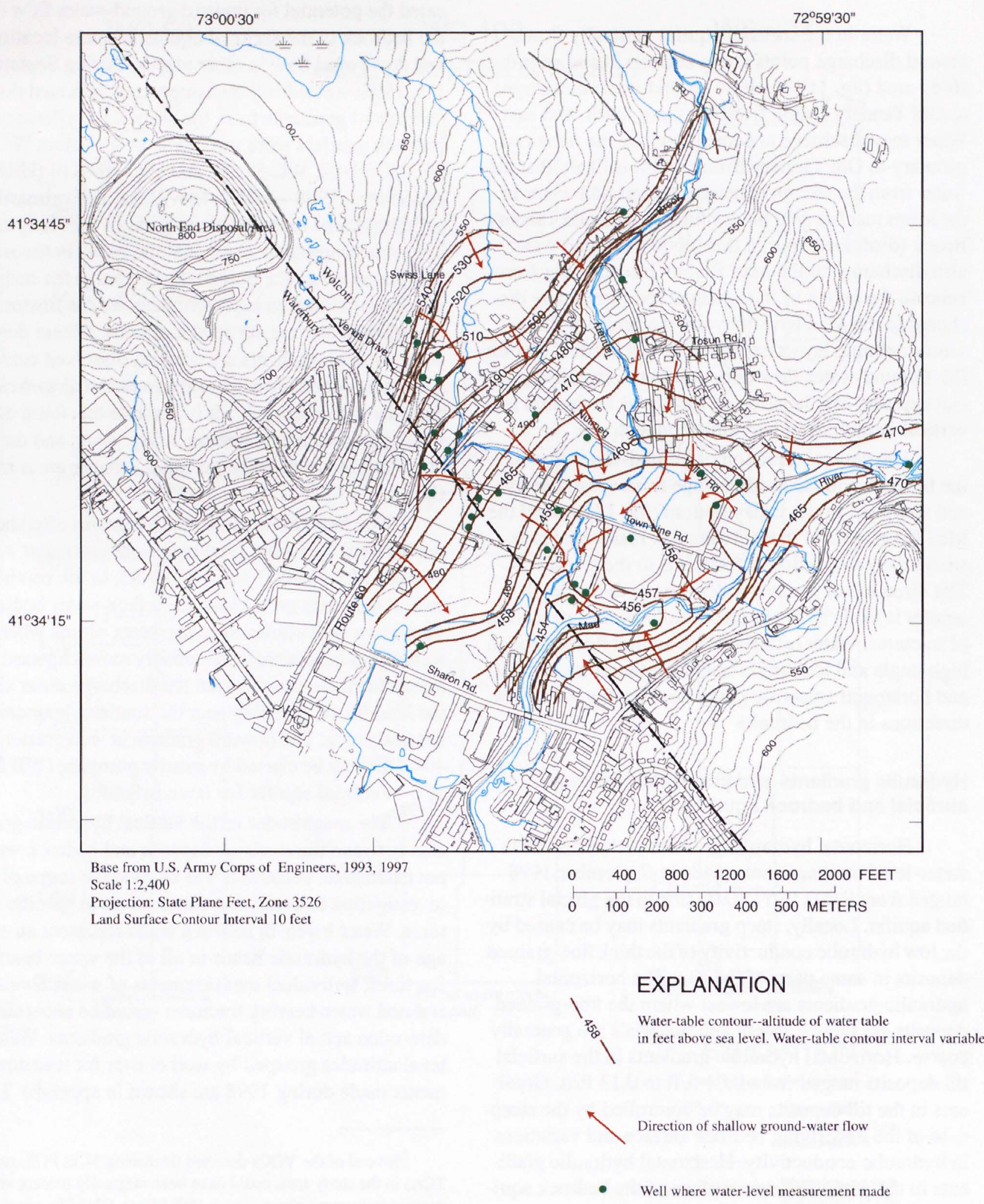

Figure 11. Altitude of the water table and direction of shallow ground-water flow in surficial aquifers, Nutmeg Valley study area, Wolcott and Waterbury, Connecticut, September 1-3, 1998. 

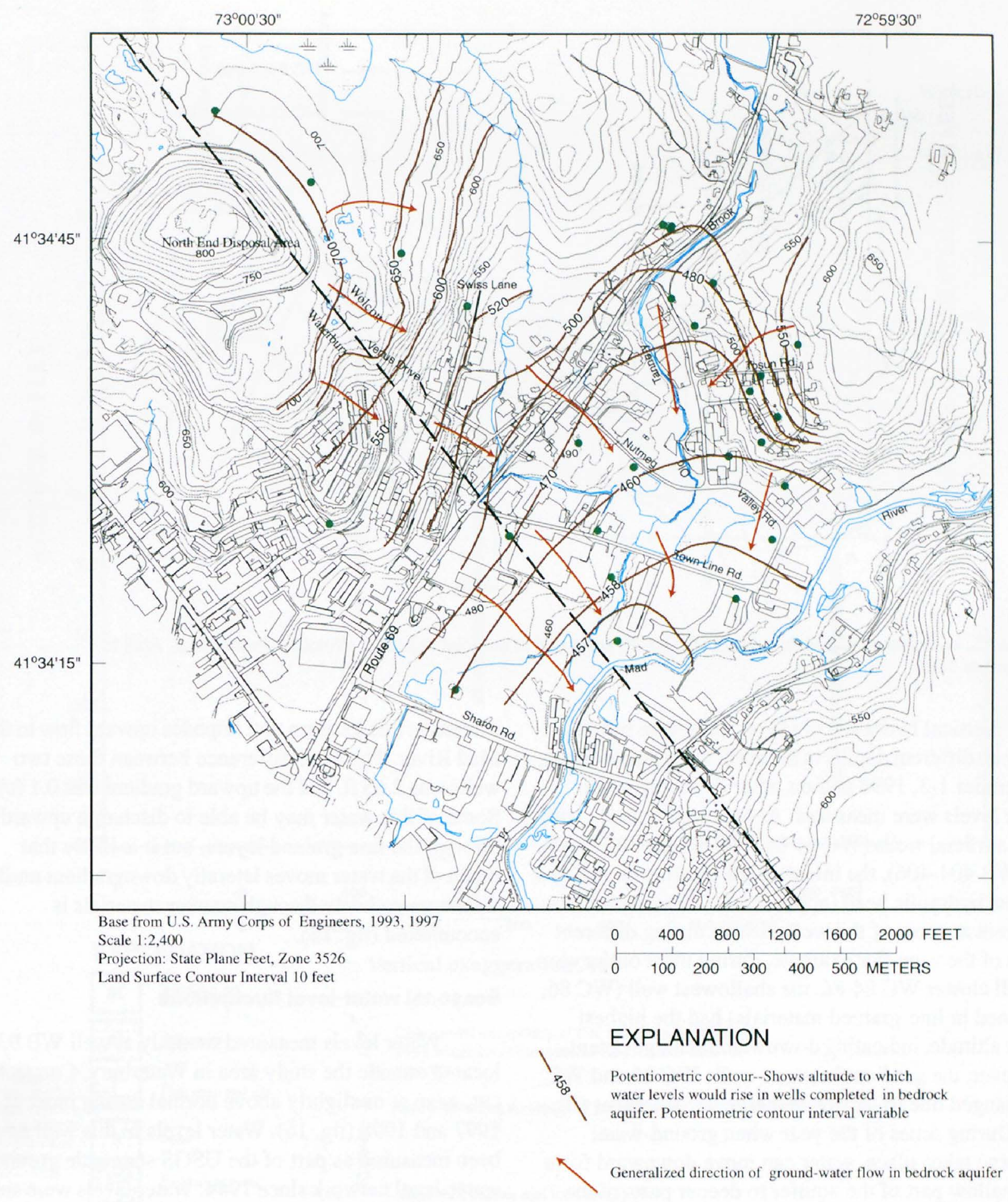

- Well where water-level measurement made

Figure 12. Altitude of the potentiometric surface and generalized ground-water-flow direction in the bedrock aquifer, Nutmeg Valley study area, Wolcott and Waterbury, Connecticut, September 1-3, 1998. 


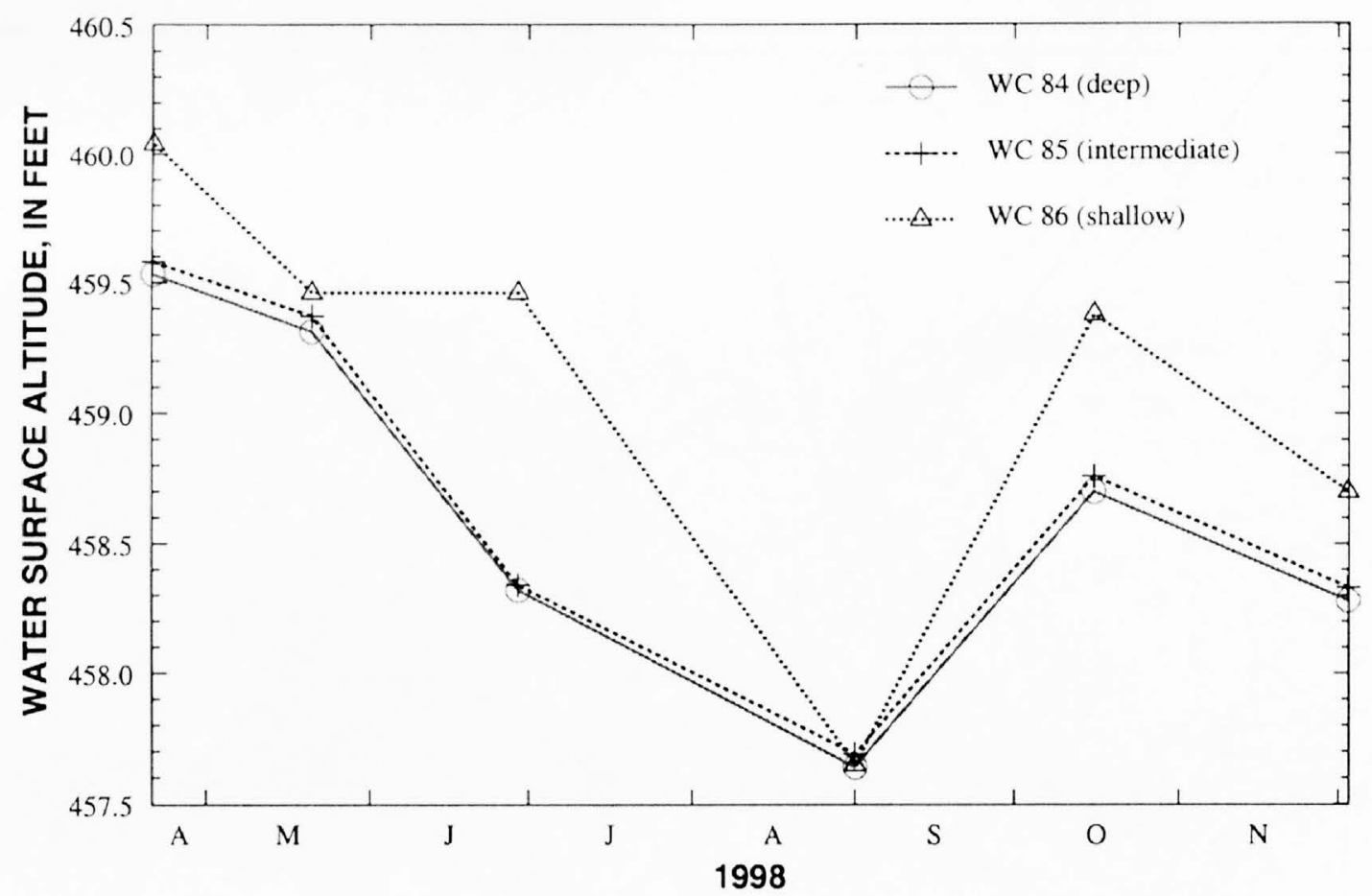

Figure 13. Water-level altitudes at wells WC $84-86$ screened in surficial deposits, Wolcott, Connecticut, April to September 1998.

Vertical hydraulic gradients also were present between different depths in the surficial deposits during September 1-3, 1998 and on other occasions when water levels were measured. At four well clusters with three surficial wells (WC 84-86, WC 80-82, WC 87-89, and WB 404-406), the intermediate-depth well had the highest hydraulic head (appendix 3). This relation was different at some of the well clusters during different times of the year. For example, during most of the year at well cluster WC 84-86, the shallowest well (WC 86; screened in fine-grained materials) had the highest water altitude, indicating downward recharge potential. However, the gradient between wells WC 86 and WC 85 changed due to lack of recharge in September (fig. 13). During times of the year when ground-water recharge takes place, water can move downward from the shallow part of the aquifer to deeper parts of the aquifer, but when recharge is reduced, flow in the intermediate parts of the aquifer would be horizontal. The changing head patterns could facilitate contaminant distribution.

A large upward gradient was present between wells WC 81-82 near the Mad River (fig. 14). This may result from a fine-grained layer between the two well screens at this location that impedes upward flow to the Mad River. The head difference between these two wells was $2.65 \mathrm{ft}$, and the upward gradient was $0.1 \mathrm{ft} / \mathrm{ft}$. Some of this water may be able to discharge upward through the fine-grained layers, but it is likely that much of the water moves laterally downgradient until a discharge pathway through coarser materials is encountered (fig. 15).

\section{Seasonal water-level fluctuations}

Water levels measured monthly at well WB 93, located outside the study area in Waterbury, Connecticut, were at or slightly above normal during most of 1997 and 1998 (fig. 16). Water levels in this well have been measured as part of the USGS statewide groundwater-level network since 1944. Water levels were similar to the long-term median for September 1998, when measurements were made for the water table and potentiometric surface maps described previously.

Water levels in the study area were highest from April to May 1998 and lowest from August to September 1998, similar to those shown in figure 16. The water levels show a pattern that is coincident with periods of 


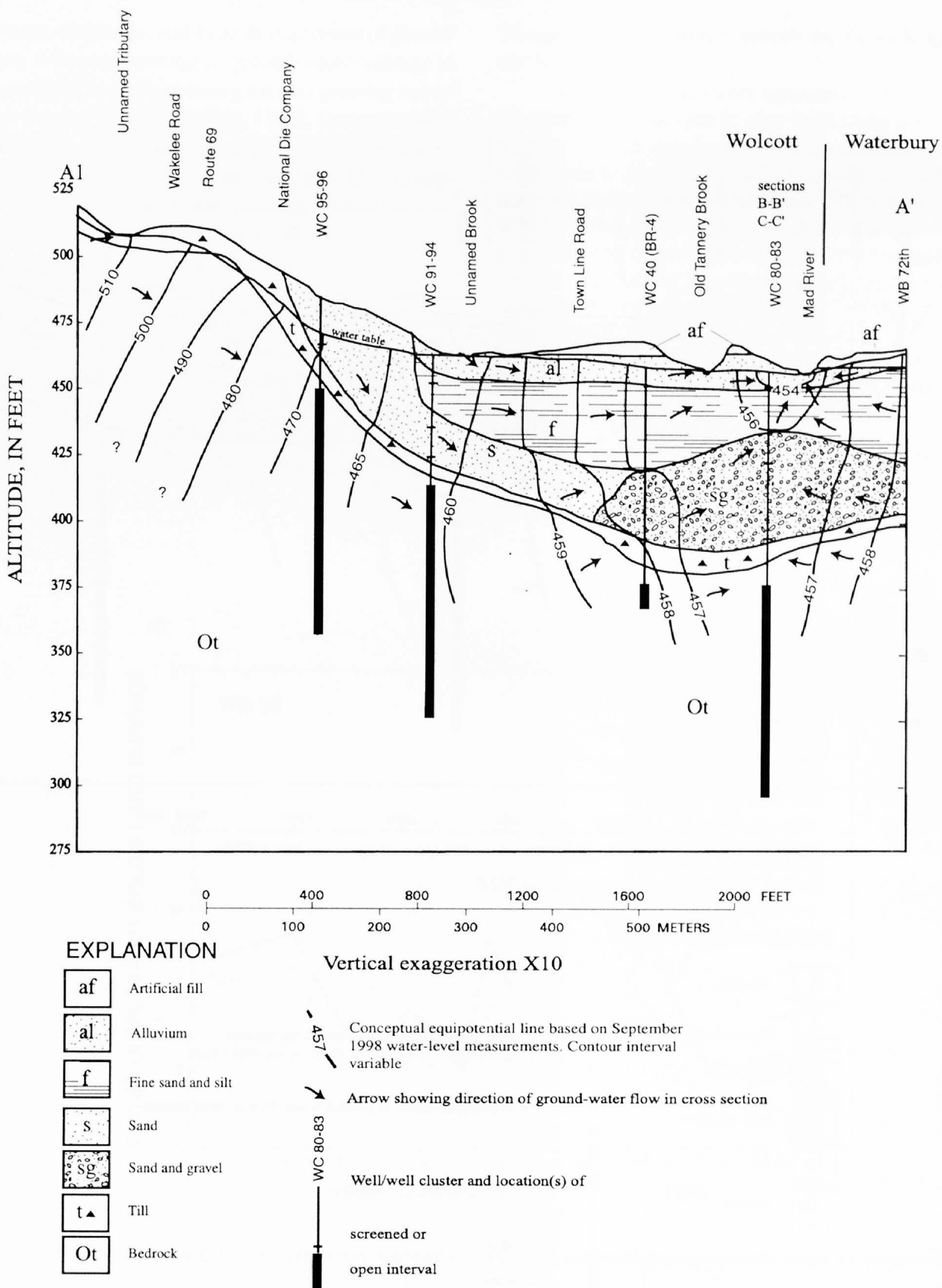

Figure 14. Conceptual model of ground-water flow in section A1-A', based on water-level measurements made September 1-3, 1998, Nutmeg Valley study area, Wolcott and Waterbury, Connecticut. 


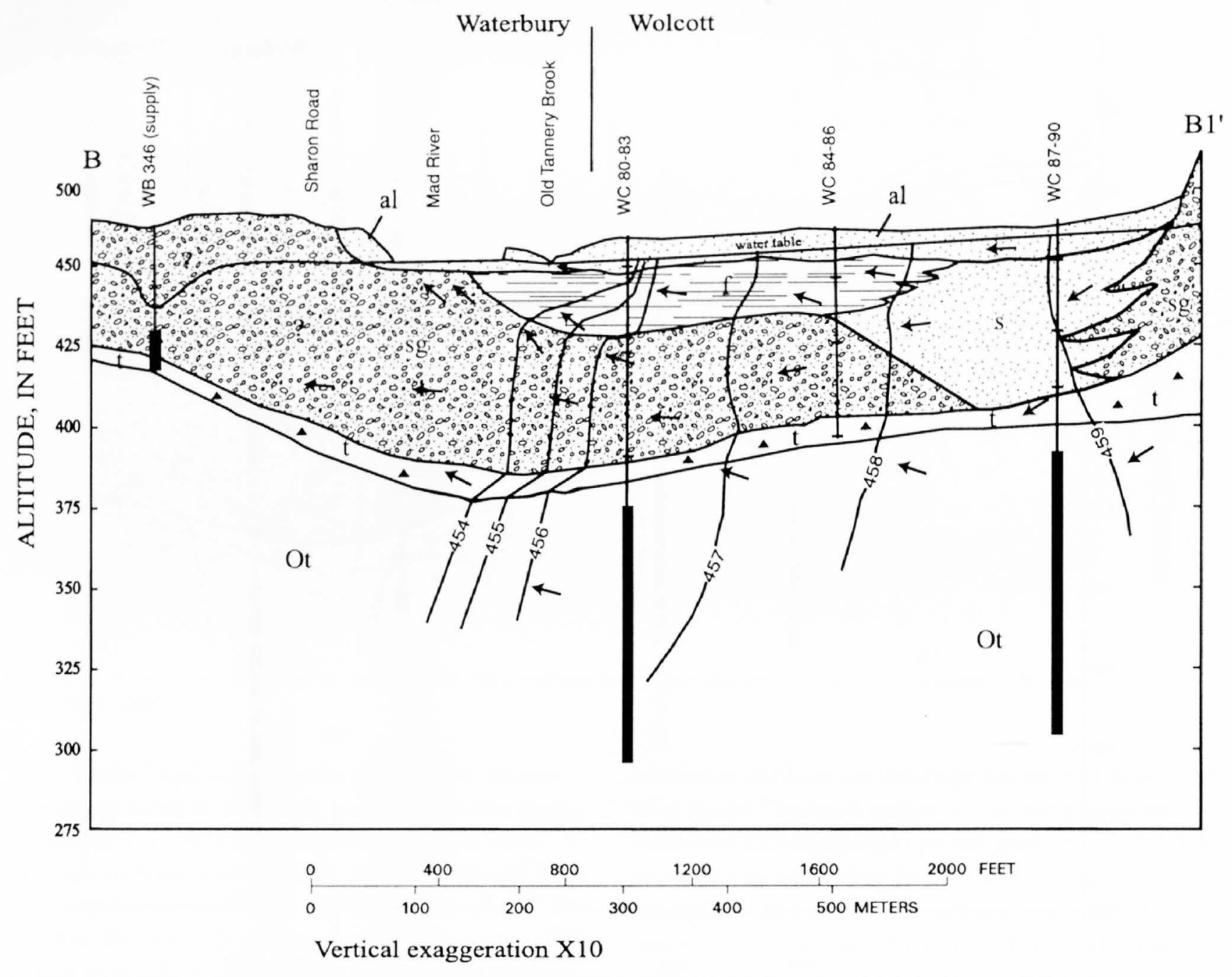

\section{EXPLANATION}

\begin{tabular}{ll|}
\hline Fl Alluvium \\
\hline Fine sand and silt \\
\hline St \\
\hline Bedrock
\end{tabular}

Conceptual equipotential line based on September

1998 water-level measurements. Contour interval 1 foot

Arrow showing direction of ground-water flow in cross section

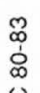

Well/well cluster and location(s) of

screened or

open interval

Figure 15. Conceptual model of ground-water flow in section B-B1', based on water-level measurements made September 1-3, 1998, Nutmeg Valley study area, Wolcott and Waterbury, Connecticut. 
recharge, discharge, and evapotranspiration of ground water. A large percentage of ground-water recharge in Connecticut takes place during the non-growing season from October to May (Melvin, 1986). Ground-water levels rise when recharge is larger than the amount of water discharging from the aquifer. From May to September, ground-water levels generally decline because recharge is less than ground-water discharge.

The range of natural water-level fluctuations from April to December 1998 was 2 to $4 \mathrm{ft}$ in areas underlain by glacial stratified deposits on the valley bottom and as large as $11 \mathrm{ft}$ in a bedrock well (WC 100) near Swiss Lane on a hillside. Water levels in wells WC 95-96 (located on a terrace) declined throughout the time period that they were measured, indicating that recharge may be delayed to late winter or early spring.
Manual water level measurements are shown in appen$\operatorname{dix} 3$.

Water levels also were measured continuously for short periods of time in nine wells using pressure transducers with data loggers. These measurements were made to determine aquifer response to precipitation and ground-water withdrawals. Water levels in WC 85, screened at intermediate depth in the stratified glacial aquifer (located about $400 \mathrm{ft}$ from the nearest stream, Old Tannery Brook) responded quickly to precipitation during periods of recharge (April to June and September to October) and generally declined for most of the summer when evapotranspiration was taking place. Water levels began to rise again in September in response to recharge (fig. 17). Additional hydrographs showing data measured by pressure transducers are shown in appendix 4 .

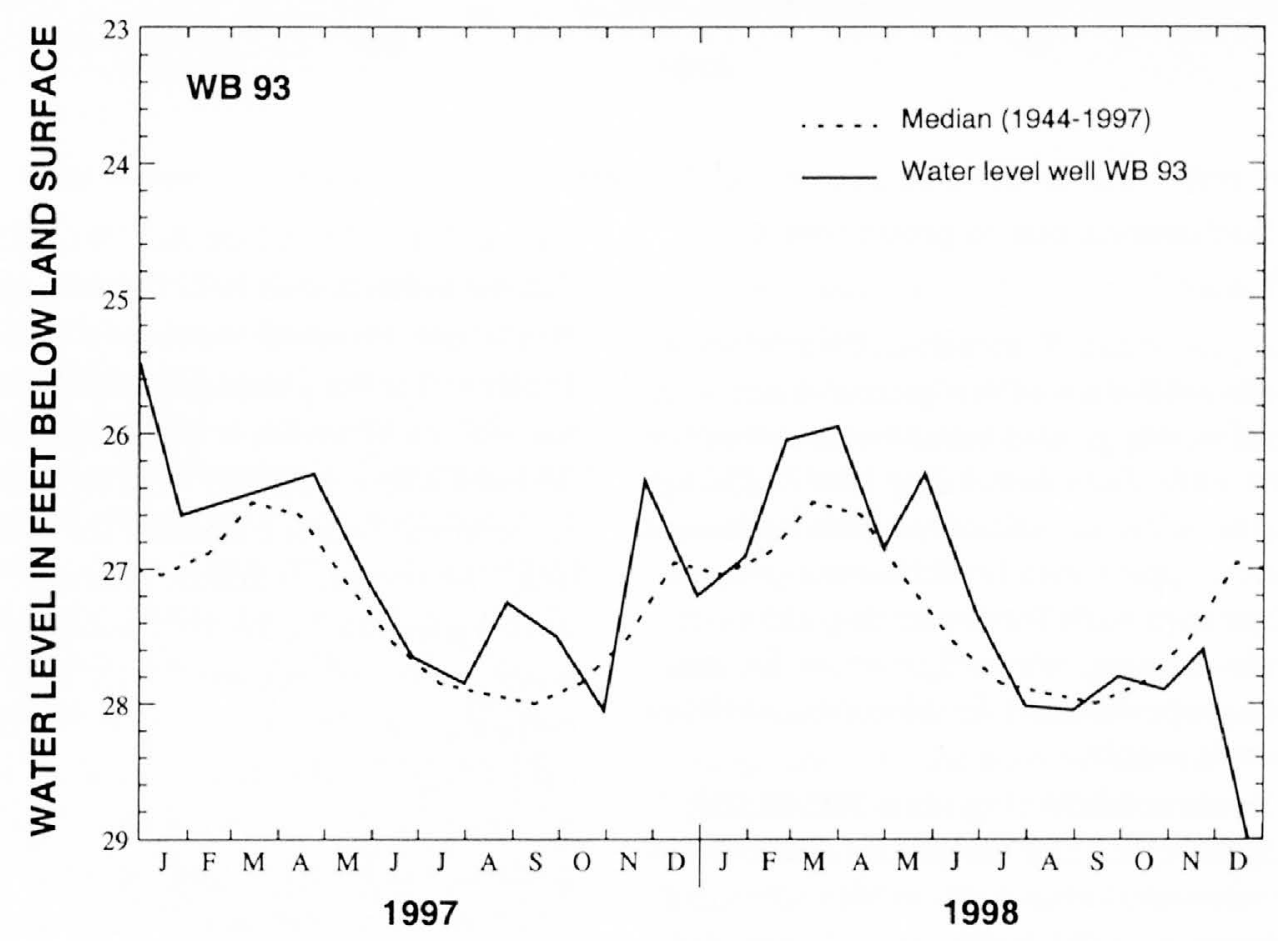

Figure 16. Water levels in well WB 93, Waterbury, Connecticut, 1997-98, and median monthly water levels for the period of record. 


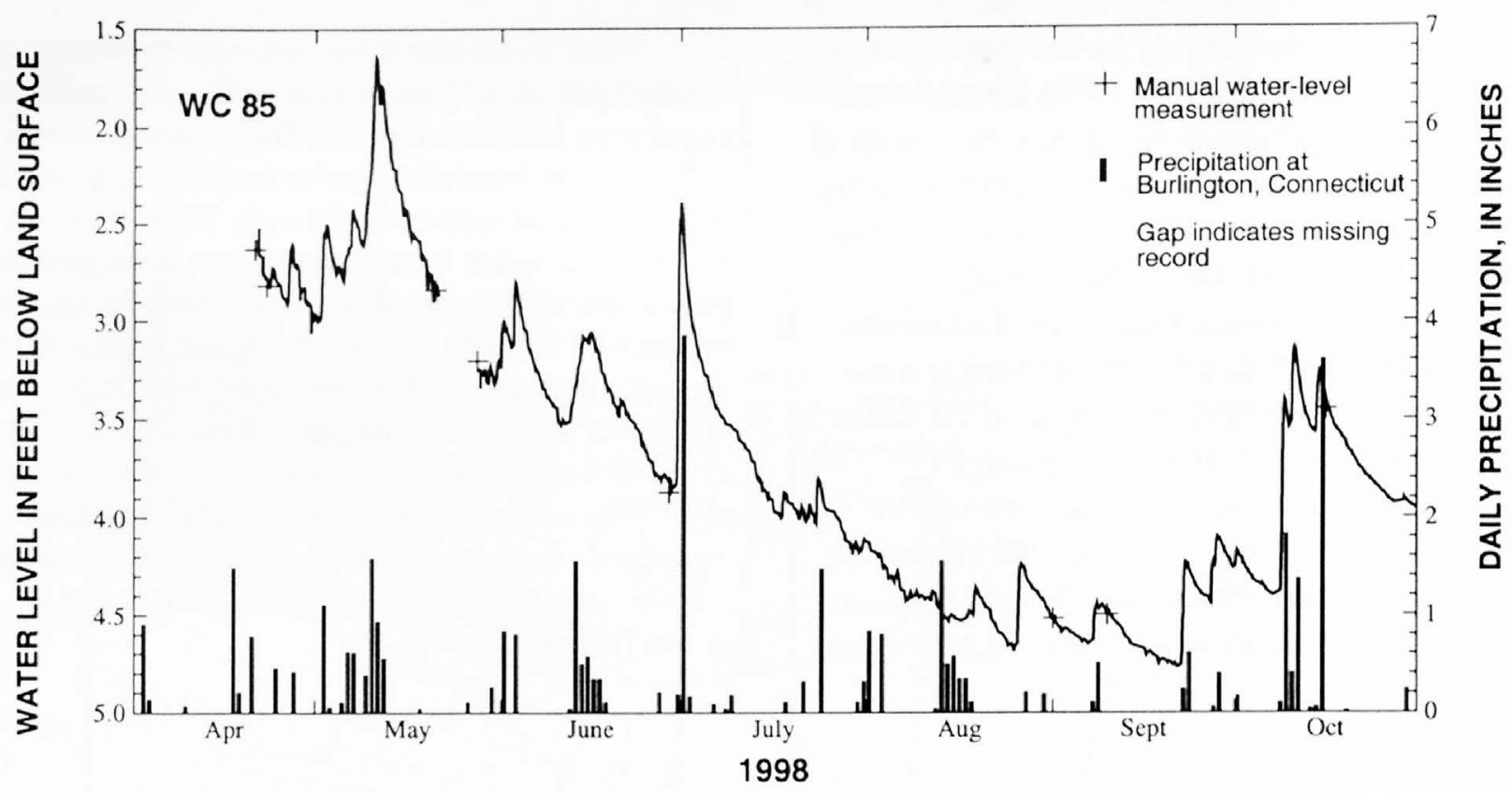

Figure 17. Continuous water levels at well WC 85 , screened in stratified glacial deposits, Wolcott, Connecticut, and daily precipitation at Burlington, Connecticut, April to October 1998.

\section{Water-level fluctuations due to ground-water withdrawals}

The analysis of data from pressure transducers installed in four wells showed that ground-water withdrawals were affecting ground-water levels at three or more locations in the study area during 1998. Although publicly-supplied water is available to most businesses in the study area, approximately 28 businesses used water from their own wells for industrial processing, cooling, vehicle washing, lawn irrigation, or for restroom facilities. Approximately 27 additional wells are used for domestic supply.

Water levels in monitoring wells WC 38 (BR-2) and WC 41 (MW-11) at 1240 Wolcott Rd. fluctuated at regular daily intervals during April to May 1998, indicating that nearby pumping, most likely for industrial purposes, caused the fluctuation (fig. 18). These waterlevel fluctuations may be caused by ground-water withdrawals used for cooling at 7 Town Line Rd., directly across Town Line Rd. from 1240 Wolcott Rd. (Mr. Garthwaite, Line Manufacturing, oral commun., 1998; Goodkind and O'dea 1985). A well-completion report for a well at 7 Town Line Rd. (WC 125, pl. 1) indicates that the bedrock well is $225 \mathrm{ft}$ deep and yields $30 \mathrm{gal} / \mathrm{min}$. From the water-level data collected, it is apparent that the pumpage has affected water levels in the bedrock as well as in the bottom of the surficial (till) deposits where well WC 41 is screened, and that the surficial and bedrock aquifers are in hydraulic connection. The vertical hydraulic gradients between the two wells varied during the daily pumping cycle. When the water levels had recovered fully from the effects of pumping, the gradient was upward from the bedrock to the surficial aquifer, and water-level altitudes differed by about $0.2 \mathrm{ft}$. Toward the end of daily pumping, the gradient was reversed, and the water level in WC 41 was higher than that in WC 38 by about $0.2 \mathrm{ft}$. This example illustrates how contamination in the surficial deposits may be induced to move into the bedrock aquifer in response to pumping a bedrock well (fig. 18). The data also indicate that the effects of pumping in the bedrock aquifer extend laterally downgradient at least $200 \mathrm{ft}$ from the pumped well. 


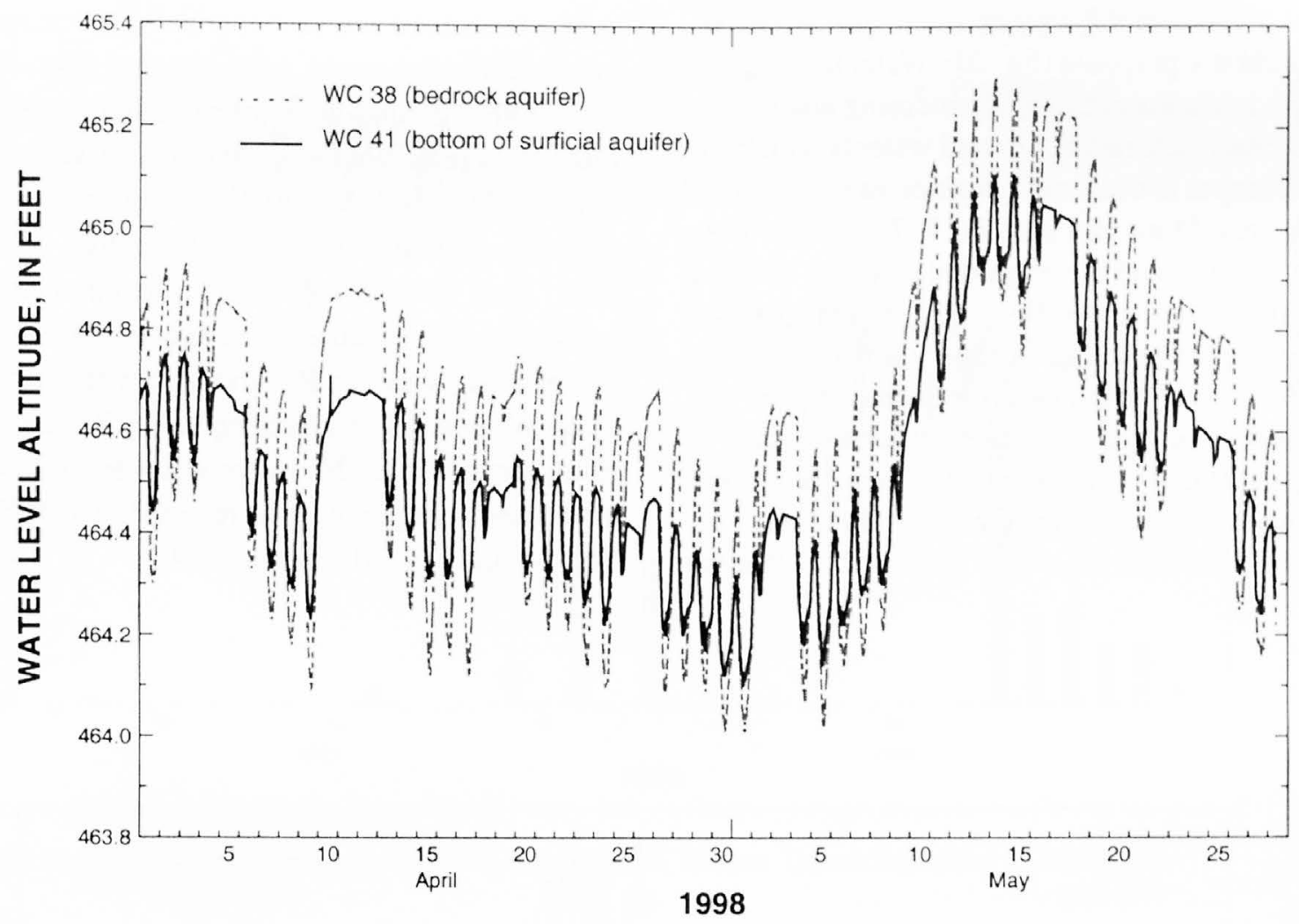

Figure 18. Water levels in wells WC 38 and WC 41, 1240 Wolcott Road, Wolcott, Connecticut, April to May 1998.

In the past, ground-water withdrawals in the Town Line Rd. area were larger than current withdrawals. A report from Goodkind and O'dea (1985) shows that other businesses located along Town Line Rd. previously used ground water for supply. Currently, these businesses are either not active or have been connected to the public water supply. The report states the well at 17 Town Line Rd. was pumped at the rate of $3 \mathrm{gal} / \mathrm{min}$ for use by one machine during the day shift. This former use translates to about $1,400 \mathrm{gal} / \mathrm{d}$, assuming an 8 -hour shift. It is possible that in the past, pumping stresses in the bedrock aquifer may have affected the distribution of contaminants by inducing contaminated ground water to move from the surficial aquifer to the bedrock aquifer.

Current ground-water withdrawals near Town Line Rd. include an undetermined amount of ground water pumped at 1240 Wolcott Rd. to seasonally irrigate lawns. The well is adjacent to the south side of the building. No information was available on the construction of this well other than that it withdraws water from the bedrock aquifer (Bud Hansen, Highland ITW, oral commun., July 1998).

Another area where ground-water levels were affected by pumping is along Sharon Rd. in Waterbury at USGS well WB 406 (fig. 19). This well is screened near the water table in the glacial stratified deposits on property owned by the U.S. Postal Service. Water levels in this well may be affected by pumping in the surficial aquifer. A well on the opposite side of Sharon Rd. (16 Sharon Rd.) is used for lawn irrigation. Water is withdrawn from the surficial aquifer at well WB 346 (pl. 1), which is about $1,000 \mathrm{ft}$ from well WB 406 (Robert Garthwaite, Cly-Del Manufacturing, oral commun., December 1998). The well-completion report (WB 346 ) indicates a yield of $250 \mathrm{gal} / \mathrm{min}$ and that the well is $27 \mathrm{ft}$ deep, 8 -in. diameter, with a 10 - $\mathrm{ft}$ screen on the bottom. Pumping from the surficial aquifer may be inducing upward flow from the bedrock aquifer. Pumping effects were apparent even after the summer irrigation season had ended, indicating that there may be other nearby ground-water withdrawals. 
At well WC 99 installed adjacent to the Tosun $\mathrm{Rd}$. residential area, daily water-level fluctuations were observed in the bedrock aquifer due to ground-water use for domestic purposes (fig. 20). Water levels generally began to decline in the early morning and recovered in the early afternoon. Ground water is withdrawn by 22 residences and at least 4 businesses in this part of the study area. Stone and others (1997) reported that the average estimated use of ground water by residents on Tosun Rd. was about $6,000 \mathrm{gal} / \mathrm{d}$. This area is served by public sanitary sewers, so the only water returned to the aquifer would be that used for lawn irrigation or other outdoor use. The continuous water-level data indicate that WC 99 is hydraulically connected to at least some of domestic supply wells in this area. The analysis of BIPS data from well WC 99 show that the primary water-bearing fractures are high angle and dip to the northwest. Other water-bearing fractures are nearly horizontal and probably provide connections between the high angle, north-dipping fractures.

Other ground-water users include at least six businesses in the Swiss Lane/Venus Drive area. Secondaries Inc. reported that they use ground water for processing (John Haras, Secondaries Inc., oral commun., June 1998). Water levels were not monitored with pressure transducers in this area. Several businesses along Wakelee Rd. and homes and businesses along Wolcott Rd. and Nutmeg Valley Rd. are currently using ground water. No major water-level fluctuations associated with pumping were noted in wells WC 96, WC 94, and WC 101 (appendix 4).

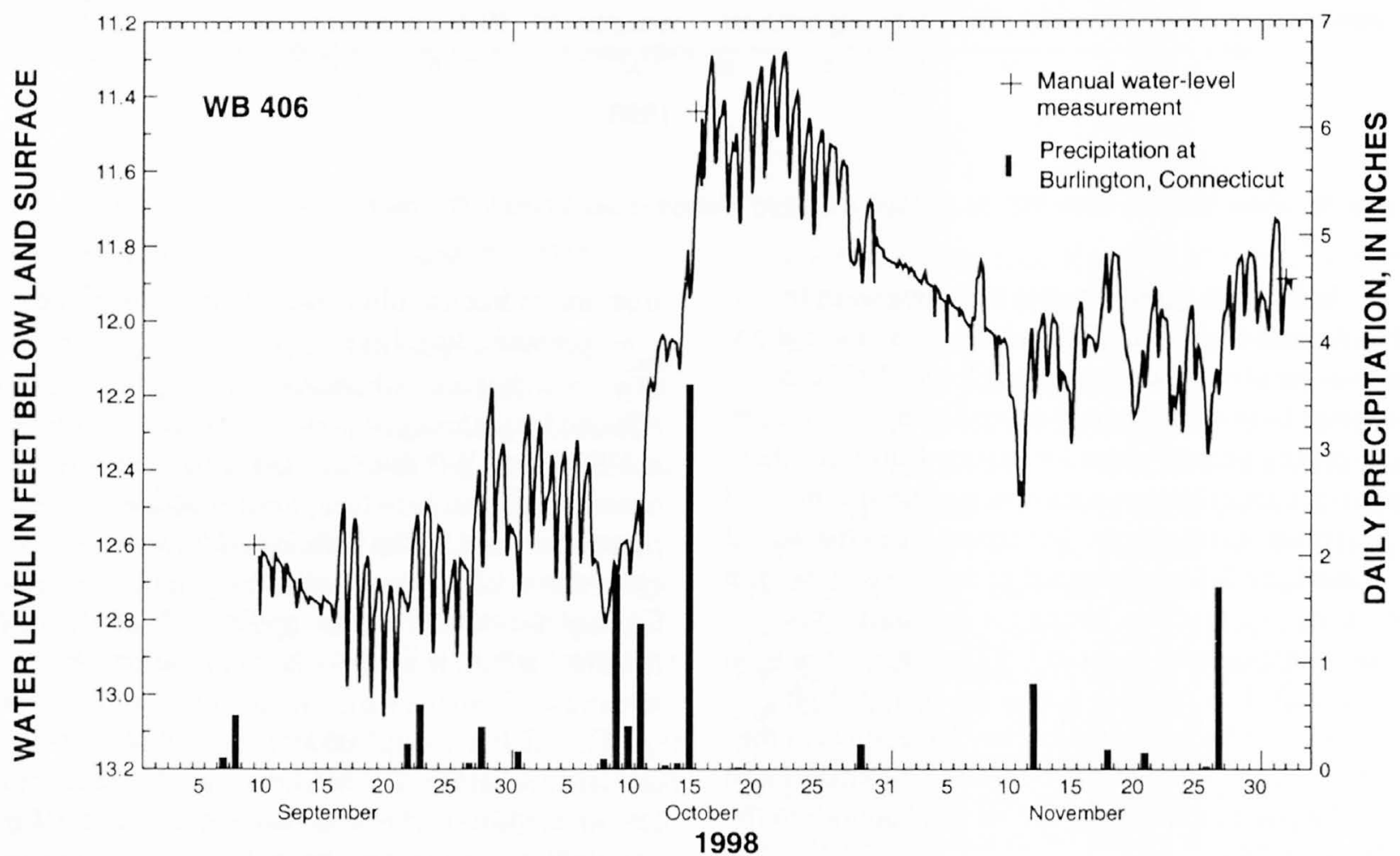

Figure 19. Water-level fluctuations in well WB 406, Sharon Road, Waterbury, Connecticut, September to November 1998. 


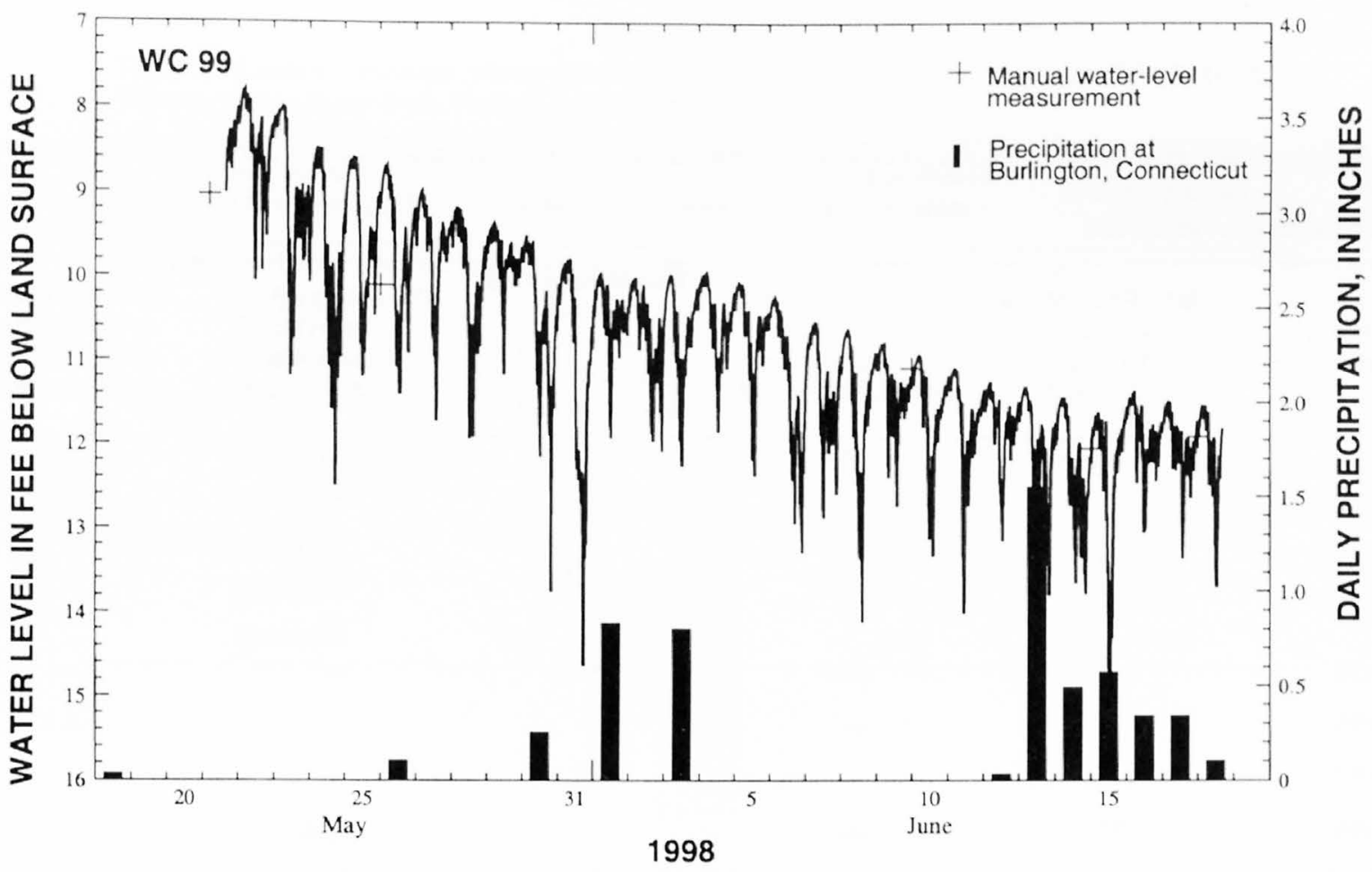

Figure 20. Water-level fluctuations in well WC 99, Tosun Road, Wolcott, Connecticut, May to June 1998.

\section{Streamflow}

Discharge measurements were made intermittently from August 1996 to July 1998 to determine the stage-to-discharge relations at several locations in the study area (table 4). Rating curves for each streamflow measurement site are shown in appendix 5. Estimates of flow duration were not made because streamflow may be affected by upstream storage and regulation on the Mad River and Old Tannery Brook. The discharge measurements also can be used to determine the amount of water discharging from the study area under different flow conditions. During low-flow periods, when the flow of the Mad River at the downstream end of the study area (01208290) was $10 \mathrm{ft}^{3} / \mathrm{s}$ or less, and all flow in the streams is likely derived from groundwater discharge, streamflow gains in the study area ranged from 0.3 to $1.4 \mathrm{ft}^{3} / \mathrm{s}$ between the upstream Mad River station (01208270) and the downstream station (01208290). This gain in discharge is equivalent to 0.19-0.93 Mgal/d. Stone and others (1997) reported that estimated ground-water withdrawals from the Superfund Site and adjacent areas to be about 0.09 $\mathrm{Mgal} / \mathrm{d}$. Because most of the water withdrawn from wells in the study area is discharged to sanitary sewers, the cumulative long-term effect of ground-water withdrawals from the area may be a reduction in groundwater discharge to streams in the study area during periods of low streamflow.

Measurements were made during low flow at additional locations during July 27-28, 1998 in conjunction with surface-water-quality sampling (table 5). The gain in streamflow on the previously mentioned section of the Mad River was $1.13 \mathrm{ft}^{3} / \mathrm{s}$. The flow at the downstream end of Old Tannery Brook was $0.98 \mathrm{ft}^{3} / \mathrm{s}$, or about 87 percent of the gain on the Mad River. This indicates that there is only a small amount of groundwater discharge directly to the Mad River from the study area. Most of the increase in flow of the Mad River can be attributed to the inflow from Old Tannery Brook north of Tosun Rd. The difference in flow along Old Tannery Brook between upstream and downstream stations was $0.23 \mathrm{ft}^{3} / \mathrm{s}$, or about 20 percent of the streamflow gain between the two Mad River stations. The flow of the unnamed tributary to Old Tannery Brook represented only about 2.7 percent of the gain. Several other small streams may contribute to this total. 
Table 4. Measurements of stream discharge in and near the Nutmeg Valley study area, Wolcott and Waterbury, Connecticut, 1996-98

[Discharge in cubic feet per second]

\begin{tabular}{|c|c|c|c|c|c|}
\hline $\begin{array}{c}\text { Date of } \\
\text { measurement }\end{array}$ & $\begin{array}{l}\text { Mad River below } \\
\text { Finch Brook, } \\
\text { Wolcott, Conn. } \\
\text { (USGS 01208270) }\end{array}$ & $\begin{array}{l}\text { Mad River at } \\
\text { Sharon Road, } \\
\text { Waterbury, Conn. } \\
\text { (USGS 01208290) }\end{array}$ & $\begin{array}{l}\text { Mad River at Frost } \\
\text { Road } \\
\text { Waterbury, Conn. } \\
\text { (USGS 01208295) } \\
\text { (shown on fig. 1) }\end{array}$ & $\begin{array}{l}\text { Old Tannery Brook } \\
\text { at Tosun Road, } \\
\text { Wolcott, Conn. } \\
\text { (USGS 01208280) }\end{array}$ & $\begin{array}{l}\text { Unnamed tributary } \\
\text { at Wolcott Road, } \\
\text { Wolcott, Conn. } \\
\text { (USGS 01208285) }\end{array}$ \\
\hline $08 / 22 / 96$ & 2.19 & 2.5 & 2.45 & 0.34 & 0.006 \\
\hline $09 / 23 / 96$ & - & 70.2 & - & 5.07 & - \\
\hline $09 / 26 / 96$ & 27.6 & - & 28.5 & 34.7 & .01 \\
\hline $10 / 21 / 96$ & - & - & - & - & 4.06 \\
\hline $10 / 24 / 96$ & - & 82.8 & 90.1 & - & - \\
\hline $11 / 26 / 96$ & - & - & - & - & 4.42 \\
\hline $12 / 02 / 96$ & - & - & 116 & - & - \\
\hline $12 / 12 / 96$ & 55.5 & - & - & 13.4 & - \\
\hline $12 / 20 / 96$ & - & 128 & 108 & 17.0 & - \\
\hline $01 / 14 / 97$ & 19.4 & - & - & - & - \\
\hline $01 / 15 / 97$ & - & - & 22.6 & - & - \\
\hline $04 / 25 / 97$ & - & 33.6 & - & 5.14 & .481 \\
\hline $05 / 20 / 97$ & - & - & 45.0 & - & - \\
\hline $05 / 28 / 97$ & 14.8 & 17.8 & 19.4 & - & - \\
\hline $05 / 29 / 97$ & - & - & - & 2.36 & .068 \\
\hline $06 / 26 / 97$ & 1.98 & 3.34 & - & - & - \\
\hline $06 / 27 / 97$ & - & - & 5.54 & 1.04 & .006 \\
\hline $10 / 17 / 97$ & 6.59 & 7.68 & 9.12 & .315 & - \\
\hline $02 / 03 / 98$ & 20.4 & 27.4 & - & 3.89 & .274 \\
\hline $02 / 04 / 98$ & - & - & 34.5 & - & - \\
\hline $02 / 18 / 98$ & - & - & - & - & 4.33 \\
\hline $06 / 04 / 98$ & 24.7 & 30.2 & - & 4.35 & \\
\hline $07 / 27 / 98$ & - & - & - & .752 & .013 \\
\hline $07 / 28 / 98$ & 7.45 & 8.58 & - & - & - \\
\hline
\end{tabular}


Table 5. Stream-discharge measurements made during low-flow sampling, July 27-28, 1998, Nutmeg Valley study area, Wolcott and Waterbury, Connecticut

\begin{tabular}{cccc}
\hline $\begin{array}{c}\text { Station number } \\
\text { (location shown on pl. 1) }\end{array}$ & $\begin{array}{c}\text { Date } \\
\text { discharge measured }\end{array}$ & $\begin{array}{c}\text { Drainage area in } \\
\text { square miles }\end{array}$ & $\begin{array}{c}\text { Discharge } \\
\text { in cubic feet per } \\
\text { second }\end{array}$ \\
\hline $\begin{array}{c}\text { Unnamed tributary to Old Tannery Brook sites } \\
\text { (1/27/98 }\end{array}$ & 0.23 & 0.02 \\
01208286 & $7 / 27 / 98$ & 0.64 & 0.03 \\
Old Tannery Brook sites & $7 / 27 / 98$ & & \\
01208280 & $7 / 27 / 98$ & 2.74 & 0.75 \\
01208288 & & 3.71 & 0.98 \\
Mad River sites & $7 / 28 / 98$ & & 7.45 \\
01208270 & $7 / 28 / 98$ & 12.4 & 8.58 \\
\hline
\end{tabular}

\section{Ground-water and surface-water interaction}

Vertical hydraulic gradients between the ground water and surface water were measured at 30 locations along Old Tannery Brook, the unnamed tributary to Old Tannery Brook, and the Mad River (fig. 21) to assist in interpreting the results of vapor-diffusion sampling. Some head measurements were made more than once to determine the effects of different streamflow conditions on gradients between the ground water and the stream. Measurements were not made at locations where the streambed material was gravel or boulders because the mini-piezometer was not durable enough to be driven into hard sediments. The measurements indicate that ground water discharged to Old Tannery Brook at many locations where the hydraulic-head measurements were made, and the vertical hydraulic gradient was from 0 to $0.2 \mathrm{ft} / \mathrm{ft}$. Measurements of specific conductance of ground water and the stream water were made to ensure that leakage was not taking place around the mini-piezometer. Typically, the ground water had higher specific conductance than water in the streams, except at site U 200.

Head measurements were made at two locations (OT 1900 and OT 2025; fig. 21, pl. 1) along Old Tannery Brook about 5 days apart, before and after a precipitation event. The upward gradient at one location
(OT 1900) decreased from 0.1 to $0 \mathrm{ft} / \mathrm{ft}$, following the precipitation (table 6). Gradients may reverse at many locations, especially in response to a large precipitation event. Measurements made at two transects (OT 2850 and OT 2900) across Old Tannery Brook were variable and indicated that the head distribution was different even where measurements were only $5 \mathrm{ft}$ apart (table 6). Head measurements in two transects across the Mad River near the southern end of the Nutmeg Valley site also indicated that this reach of the river is receiving discharge from the aquifer. The hydraulic gradients measured between the stream and ground water in the unnamed tributary to Old Tannery Brook from vapordiffusion sampling locations U 200 to U 600 was downward, indicating that the stream is recharging the ground water between these locations. Measurements made during low-streamflow conditions on July 28 , 1998 were similar; stream levels were higher than ground-water levels. This reach of stream potentially loses water to the aquifer during most flow conditions (table 6). An analysis of aerial photographs from the present and from 1965 and earlier indicates that this section of the stream has been moved more than once during the past 40 years. Re-routing the stream channel upgradient from its former position possibly has separated the stream from the water table, resulting in a water level higher than that in the aquifer. 
Table 6. Measurements of vertical hydraulic gradient between surface water and ground water and specific conductance measurements in surface water and substream ground water at vapor-diffusion sampling locations along streams draining the Nutmeg Valley study area, Wolcott and Waterbury, Connecticut, November 1997 and July 1998

[Site locations shown on plate 1. A negative gradient indicates water level in the stream was higher than ground-water level. $\mu \mathrm{S} / \mathrm{cm}$, microsiemens per centimeter; ${ }^{\circ} \mathrm{C}$; degrees Celsius; lew, left edge of river looking downstream; rew, right edge of river looking downstream; *, specific conductance may not be representative of ground water because gradient is negative or zero]

\begin{tabular}{|c|c|c|c|c|c|c|}
\hline $\begin{array}{l}\text { Location } \\
\text { (shown on } \\
\text { pl. 1) }\end{array}$ & Date & $\begin{array}{l}\text { Depth of head } \\
\text { measurement in } \\
\text { feet below } \\
\text { streambed }\end{array}$ & $\begin{array}{c}\text { Vertical } \\
\text { hydraulic } \\
\text { gradient in } \\
\text { foot/foot }\end{array}$ & $\begin{array}{c}\text { Specific } \\
\text { conductance } \\
\text { of ground } \\
\text { water in } \\
\mu \mathrm{S} / \mathrm{cm} \text { at } 25^{\circ} \mathrm{C}\end{array}$ & $\begin{array}{c}\text { Specific } \\
\text { conductance } \\
\text { of } s \text { urface } \\
\text { water in } \\
\mu \mathrm{S} / \mathrm{cm} \text { at } 25^{\circ} \mathrm{C}\end{array}$ & Remarks \\
\hline OT 1550 & $11 / 26 / 97$ & 2.80 & 0.003 & 267 & & \\
\hline OT 1650 & $11 / 26 / 97$ & 1.85 & 0.080 & 199 & 168 & \\
\hline OT 1800 & $11 / 26 / 97$ & 2.60 & 0.000 & *164 & & \\
\hline OT 1900 & $11 / 21 / 97$ & 3.15 & 0.100 & & & \\
\hline OT 1900 & $11 / 26 / 97$ & 2.20 & 0.000 & 209 & 170 & \\
\hline OT 1900 & $11 / 26 / 97$ & 2.90 & 0.009 & & 170 & $\begin{array}{l}4 \text { feet from previous } \\
\text { measurement }\end{array}$ \\
\hline OT 2025 & $11 / 21 / 97$ & 1.70 & 0.010 & 273 & & \\
\hline OT 2025 & $11 / 26 / 97$ & 1.72 & 0.020 & 265 & & \\
\hline OT 2200 & $11 / 21 / 97$ & 3.70 & 0.200 & 242 & & Flowing \\
\hline OT 2350 & $11 / 21 / 97$ & 3.60 & 0.003 & 365 & & \\
\hline OT 2500 & $11 / 21 / 97$ & 2.25 & 0.010 & 343 & & \\
\hline OT 2850 lew & $11 / 12 / 97$ & 2.75 & 0.050 & 331 & & \\
\hline OT 2850 & $11 / 17 / 97$ & 2.10 & 0.200 & 335 & 220 & \\
\hline OT 2850 rew & $11 / 17 / 97$ & 2.65 & 0.200 & 330 & 220 & \\
\hline OT 2900 lew & $11 / 17 / 97$ & 1.70 & 0.030 & 322 & & \\
\hline OT 2900 & $11 / 17 / 97$ & 2.40 & 0.020 & 349 & 213 & \\
\hline OT 2900 rew & $11 / 17 / 97$ & 3.30 & 0.070 & 350 & 207 & \\
\hline OT 3125 & $11 / 21 / 97$ & 3.45 & 0.030 & 136 & & \\
\hline OT 3275 lew & $11 / 21 / 97$ & 2.60 & 0.050 & 121 & & \\
\hline OT 3275 & $11 / 21 / 97$ & 3.00 & 0.040 & 137 & & \\
\hline U 200 & $11 / 21 / 97$ & 2.70 & -0.140 & $* 148$ & 358 & \\
\hline U 200 & $07 / 28 / 98$ & 3.10 & -0.019 & $* 136$ & & \\
\hline U 300 & $11 / 21 / 97$ & 3.65 & -0.005 & $* 385$ & & \\
\hline U 300 & $07 / 28 / 98$ & 3.60 & -0.049 & *198 & & \\
\hline U 400 & $11 / 21 / 97$ & 3.45 & -0.040 & *295 & & \\
\hline$\cup 400$ & $07 / 28 / 98$ & 2.35 & -0.006 & $*_{175}$ & & \\
\hline U 500 & $11 / 21 / 97$ & 1.70 & -0.140 & $* 427$ & & \\
\hline U 500 & $07 / 28 / 98$ & 3.10 & -0.142 & $* 235$ & & \\
\hline U 600 & $11 / 21 / 97$ & 1.70 & -0.006 & & 332 & “ \\
\hline U 600 & $07 / 28 / 98$ & 2.60 & -0.042 & $* 209$ & & \\
\hline U 700 & $11 / 21 / 97$ & 1.15 & 0.000 & & & $\begin{array}{l}\text { Compact gravel } \\
\text { bottom }\end{array}$ \\
\hline MR 3200 lew & $11 / 26 / 97$ & 2.40 & 0.012 & 239 & 153 & \\
\hline MR 3300 lew & $11 / 26 / 97$ & 3.00 & 0.044 & 183 & & \\
\hline MR 3300 & $11 / 26 / 97$ & 4.00 & 0.024 & 193 & & \\
\hline MR 3300 rew & $11 / 26 / 97$ & 4.00 & 0.020 & 165 & & \\
\hline MR 3700 rew & $11 / 26 / 97$ & 2.20 & 0.082 & 407 & & \\
\hline MR 3700 & $11 / 26 / 97$ & 2.50 & 0.217 & 189 & & \\
\hline MR 3700 lew & $11 / 26 / 97$ & 1.80 & 0.157 & 246 & & \\
\hline
\end{tabular}




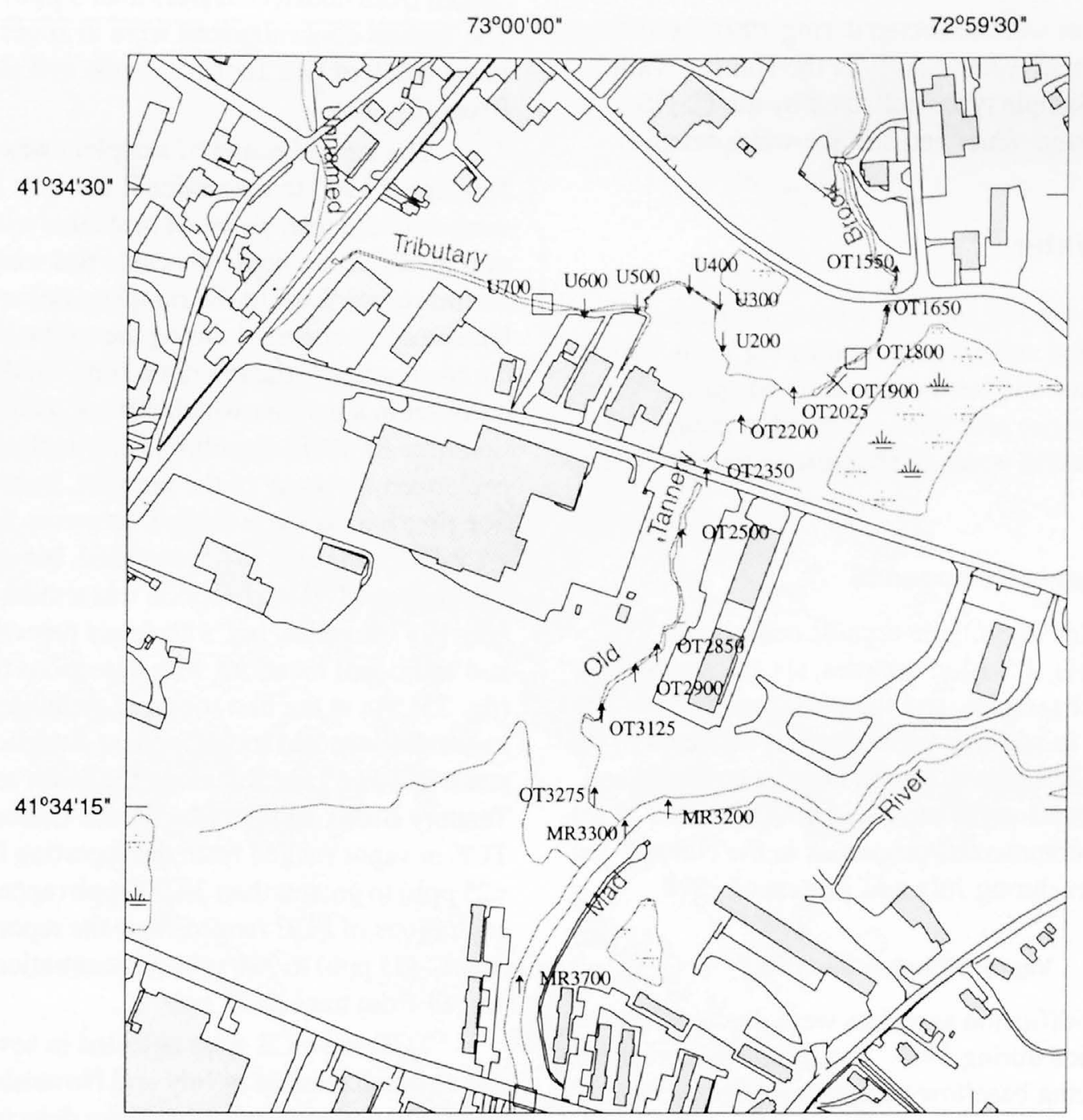

Base from U.S. Army Corps of Engineers, 1993, 1997

Scale 1:2,400

Projection: State Plane Feet, Zone 3526

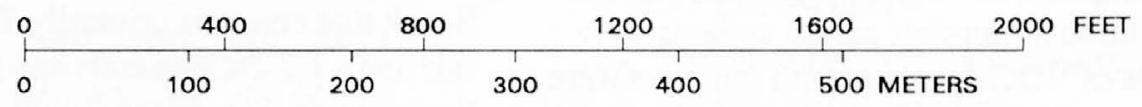

\section{EXPLANATION}

$\uparrow$ Hydraulic gradient upward from ground water to stream

$\downarrow$ Hydraulic gradient downward from stream to ground water

$X$ Variable hydraulic gradient

No hydraulic gradient

Figure 21. Locations where vertical gradient was measured between streams and ground water, Nutmeg Valley study area, Wolcott and Waterbury, Connecticut, November 1997. 


\section{WATER QUALITY OF THE NUTMEG VALLEY AREA}

Samples were collected during 1997-98 to determine the current water quality in the Nutmeg Valley study area. Sample types collected by the USGS included ground-water and surface-water samples.

\section{Ground Water}

Ground-water samples were collected from newly installed and existing monitoring wells, supply wells at homes and businesses, and one spring. Vapordiffusion samples also were collected to indicate the quality of ground water discharging to streams in the study area.

\section{Volatile Organic Compounds}

Samples for volatile organic compounds included vapor-diffusion samples, six substream ground-water samples, and samples from wells as indicated above. In addition to the samples collected by the USGS, the Chesprocott Health District collected and analyzed ground-water samples for VOCs from 35 residential and commercial properties in the Nutmeg Valley study area during July and August of 1998.

\section{Vapor-Diffusion Sampling}

Vapor-diffusion samplers were deployed and analyzed twice during 1997. The samplers were to be retrieved during baseflow conditions when groundwater was discharging to streams; however, some precipitation did occur in July and November 1997 during sampler retrieval. Sampling locations for the second round of sampling differed slightly from those of the first round. Additional transects across streams were installed in areas of VOC detection, and samplers were not installed in the unnamed tributary to Old Tannery Brook in the area directly east of the North End Disposal Area because the stream was nearly dry.

Results from the first round of sampling were primarily limited to analysis of the compounds TCE and PCE. The gas chromatograph was calibrated for these compounds, as well as for benzene, toluene, ethylbenzene, and xylenes (BTEX). Tape used to wrap the samplers during the first round of sampling was found to contain BTEX compounds; therefore, the detections of these compounds in the first round of vapor-diffusion sampling are not reported. Concentrations of TCE in July 1997 ranged from undetected (less than $5 \mathrm{ppb}$ ) to $4,800 \mathrm{ppb}$ (appendix 6). Concentrations of PCE ranged from undetected (less than $5 \mathrm{ppb}$ ) to $781 \mathrm{ppb}$. The highest concentrations were in zones along the lower reach of Old Tannery Brook and along the Mad River (fig. 22).

The second round of samplers was retrieved in November 1997 to determine if the July 1997 results were reproducible. To avoid problems with contamination by BTEX compounds, cable ties were used to secure survey flags to the samplers rather than tape. One problem occurred during the calibration of the gas chromatograph-the retention time window was initially set in a manner which did not include the retention time for PCE; therefore, PCE analysis was not performed for many of the samples. Because the retention time window was shifted, however, the compound c 1,2-DCE was able to be identified, but not quantified. The pattern of VOC detection was similar to that of the July 1997 samples, but with fewer detections of PCE and additional locations with detections of $c 1,2-\mathrm{DCE}$ (fig. 23). As in the first round of sampling, the highest concentrations and most frequent detections were south of Town Line Rd. along the lower reaches of Old Tannery Brook and the Mad River. Concentrations of TCE in vapor ranged from the reporting limit (trace, $<25 \mathrm{ppb}$ ) to greater than $30,000 \mathrm{ppb}$ (appendix 7). Concentrations of PCE ranged from the reporting limit (trace, $<25 \mathrm{ppb}$ ) to $390 \mathrm{ppb}$. Concentrations of benzene ranged from trace to $51 \mathrm{ppb}$.

TCE and PCE were detected in several of the same stream reaches in July and November 1997. The highest vapor concentrations were detected along Old Tannery Brook at vapor-diffusion sampling locations OT 2850 and OT 2900 . This area is adjacent to a known contamination area on the western side of Old Tannery Brook that contains primarily TCE, PCE, vinyl chloride and $c$ 1,2-DCE in soils and ground water (Loureiro Engineering Associates, 1998a, b). Ground-water contamination by TCE also has been documented on the eastern side of Old Tannery Brook (HRP Associates, 1991).

Other high vapor concentrations of VOCs were detected at MR 2090-2200 and MR 3500-3700 along the Mad River. These areas are near the eastern and southern limits of the fine-grained deposits and may be zones where ground water from below the fine-grained deposits (figs. 3 and 15) discharges to the Mad River. Another stream reach where VOCs were detected in vapor samples was between U 1200 and U 1900 along 


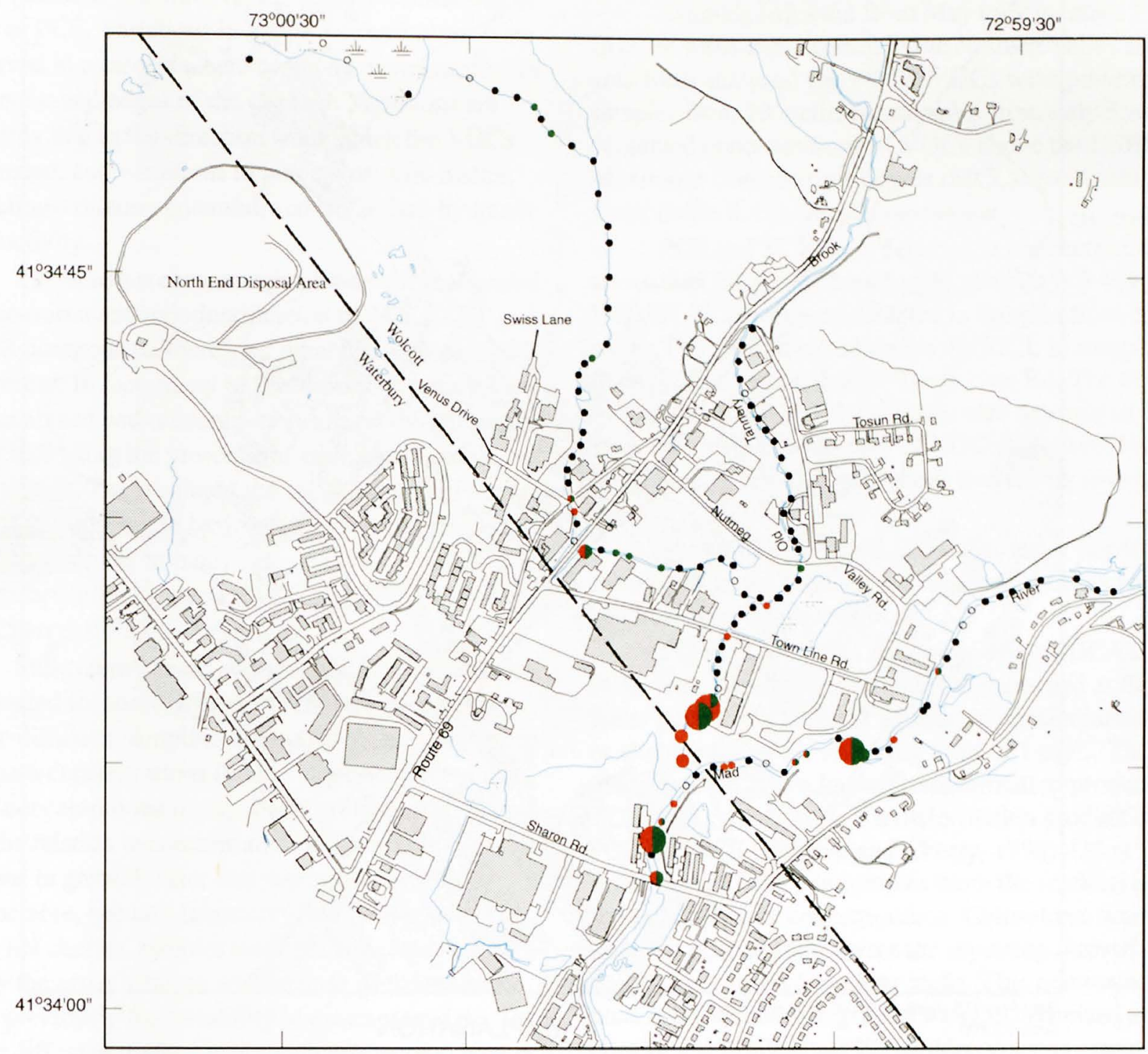

Base from U.S. Army Corps of Engineers, 1993, 1997 Scale 1:2,400

Projection: State Plane Feet, Zone 3526 $\begin{array}{ccccccc}0 & 400 & 800 & 1200 & 1600 & 2000 & \text { FEET } \\ 1 & 1 & & 1 & 1 & 1 & 1 \\ 0 & 100 & 200 & 300 & 400 & 500 & \text { METERS }\end{array}$

\section{EXPLANATION}

- Trichloroethene and tetrachloroethene not detected

- Sampler lost or destroyed

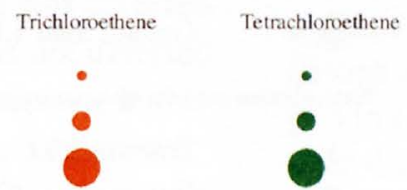

Concentrations in parts per billion by volume

Trace to 100

Greater than 100 to 1,000

Greater than 1,000

Trichloroethene and te trachloroethene detected- - highest concentration shown

- Trace to 100

- Greater than 100 to 1,000

B Greater than 1,000

Figure 22. Distribution and concentration of trichloroethene and tetrachloroethene in streambeds by vapor-diffusion sampling and analysis method, Nutmeg Valley study area, Wolcott and Waterbury, Connecticut, July 1997. 


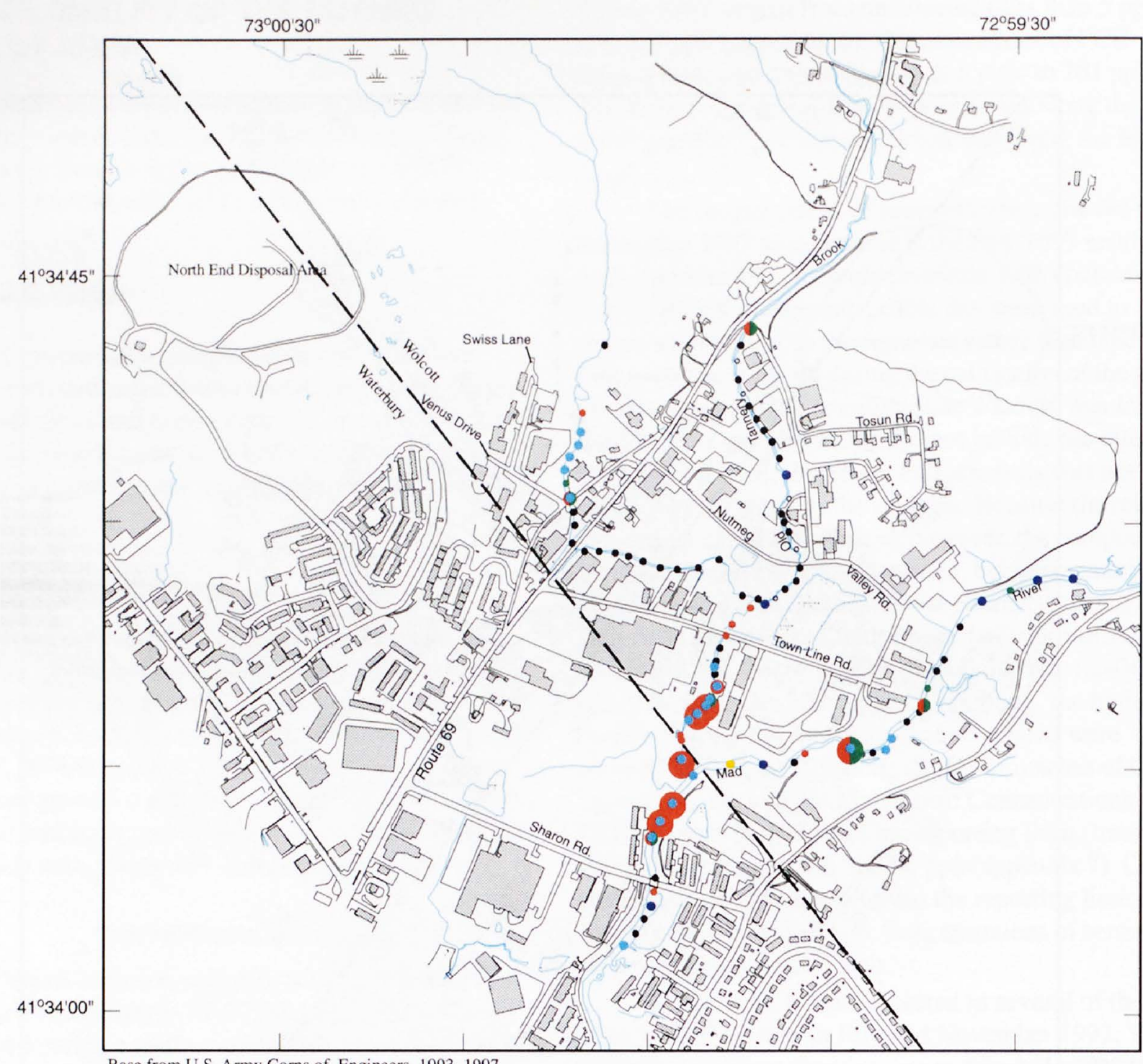

Base from U.S. Army Corps of Engineers, 1993, 1997 EXPLANATION
Scale 1:2,400

Projection: State Plane Feet, Zone 3526

- Trichloroethene and tetrachloroethene not detected
Sampler lost or destroyed
Concentrations in parts per billion by volume
Greater than 1,000
G $\quad 400 \quad 300 \quad 400 \quad 500$ METERS

Figure 23. Distribution and concentration of trichloroethene, tetrachloroethene, cis 1,2-dichloroethene, and benzene in streambeds by vapor-diffusion sampling and analysis method, in the Nutmeg Valley study area, Wolcott and Waterbury, Connecticut, November 1997. 
the unnamed tributary to Old Tannery Brook. Several other locations had trace to $100 \mathrm{ppb}$ concentrations of TCE or PCE. Variations in vapor concentrations were observed in transects where samplers were installed in the center and edges of the channel. Variations are probably due to the direction from which the VOCs originated, and variations in percent organic matter, reduction oxidation potential, and streambed-hydraulic conductivity.

The field gas chromatograph was only calibrated for measurement and identification of TCE, PCE, and BTEX compounds; therefore, other VOCs also could be present. In fact, many of the vapor-diffusion samples analyzed had unidentified peaks on the chromatogram indicating the presence of additional organic compounds. The results of the second round of vapordiffusion sampling in November 1997 indicated $c$ 1,2DCE was present in many samples. This compound is a transformation product of PCE and TCE (Pankow and Cherry, 1996).

Substream ground-water samples were collected at selected locations where VOCs were detected by vapor-diffusion sampling along Old Tannery Brook to compare concentrations (table 7). A comparison of TCE concentrations in vapor and ground water shows that the relation in concentration was variable. Concentrations in ground water and vapor are not directly comparable, because laboratory and field conditions were not similar, samples were not collected from precisely the same location and because of the reasons cited previously for variability in the transect data. The vapor diffusion method was a valuable reconnaissance tool, but should not be used to infer ground-water concentrations.

Concentrations in vapor ranged from 0.27 to 27.3 times higher than concentrations in the substream ground-water samples. In addition, PCE was detected in some vapor-diffusion samples but was not detected in any of the ground-water samples. Variations in the relation between substream vapor and ground-water concentrations are probably related to substream variations in hydraulic conductivity, percent organic matter in sediments, redox conditions, hydraulic head, and the physical/chemical properties of the VOCs.

\section{Well samples}

Samples collected from May to September 1998 from 44 wells and 1 spring in the Nutmeg Valley study area were analyzed for VOCs. VOCs were present in samples from 13 wells, but samples from only 3 wells contained concentrations of VOCs above the USEPA Maximum Contaminant Levels (MCLs) for drinking water (table 8, fig. 24).

PCE and TCE were detected at concentrations above the USEPA MCL of $5 \mu \mathrm{g} / \mathrm{L}$ at wells WB 404 and WB 407. TCA also was detected in samples from these wells. TCE was detected above the MCL in samples from WC 101 located at 17 Town Line Rd. The transformation product $c 1,2-\mathrm{DCE}$ was also detected in WC 101. This well has a history of VOC detections, but concentrations of TCE have been decreasing over time (fig. 2).

The sampling results show that many samples from wells in the surficial and bedrock aquifers were generally free from detections.

TCA, $c$ 1,2-DCE, 1,1 dichloroethane (DCA), and PCE, were detected in well WC 95 (screened at the water table in the surficial aquifer) at concentrations at or slightly above the reporting limit of $1 \mu \mathrm{g} / \mathrm{L}$. The compound DCA is a known transformation product of TCA, and $c 1,2-\mathrm{DCE}$ is a transformation product of PCE and TCE (Pankow and Cherry, 1996). Other detections of VOCs in samples from the surficial aquifer had fairly low concentrations. Chloroform was detected at or slightly above the reporting limit of $1 \mu \mathrm{g} / \mathrm{L}$ in samples from four wells. This compound is commonly detected in ground water in urbanized areas (Grady and Mullaney, 1998). Chloroform is present in most public water supplies treated with chlorine. The chloroform could originate from watering of lawns or from leaky water or sewer lines, or from the degradation of carbon tetrachloride (Pankow and Cherry, 1996), which was previously detected at high concentrations in ground water in the Nutmeg Valley area (Stone and others, 1997). Benzene was detected at 2 ppb in samples from well WC 89. This well is screened near the water table in the glacial stratified aquifer. Stone and others (1997, pl. 4) summarized data from two bedrock supply wells near well WC 89 that contained benzene and other BTEX compounds, indicative of gasoline contamination. 


\begin{tabular}{|c|c|c|c|c|c|c|c|c|c|c|c|c|}
\hline $\begin{array}{l}\text { downstream } \\
\text { [Vapor concen } \\
{ }^{*} \text {, sample scree } \\
\text { ground water t }\end{array}$ & $\begin{array}{l}\text { end of } \mathrm{Ol} \\
\text { trations are in } \\
\text { ned for VOC } \\
\text { o the stream] }\end{array}$ & $\begin{array}{l}\text { Tannery } \\
\text { parts per bil } \\
\text { in the field }\end{array}$ & $\begin{array}{l}\text { ook, Nutn } \\
\text { a by volume } \\
\text { ly; **, cis } 1\end{array}$ & $\begin{array}{l}\text { Valley stu } \\
\text { ound-water } 0 \\
\text { ichloroethen }\end{array}$ & $\begin{array}{l}\text { dy area, } N \\
\text { oncentration } \\
\text { e not quantif }\end{array}$ & $\begin{array}{l}\text { mber } 12 \text { an } \\
\text { aicrograms pe } \\
\text { s, not sample }\end{array}$ & $\begin{array}{l}7,1997 \\
\text { r. lew, left ed } \\
\text { not applicat }\end{array}$ & $\begin{array}{l}\text { f river looking do } \\
\text { nd, not detected; }\end{array}$ & $\begin{array}{l}\text { wnstream; rew, rig } \\
\text { less than; >, grea }\end{array}$ & $\begin{array}{l}\text { ht edge of str } \\
\text { ter than; }+ \text {, ir }\end{array}$ & $\begin{array}{l}\text { am looking do } \\
\text { dicates upward }\end{array}$ & $\begin{array}{l}\text { mstream; } \\
\text { gradient from }\end{array}$ \\
\hline \multirow[b]{2}{*}{$\begin{array}{l}\text { Sampling } \\
\text { location } \\
\text { (shown on } \\
\text { pl. 1) }\end{array}$} & \multirow[b]{2}{*}{ Date } & \multicolumn{2}{|c|}{ Trichloroethene } & \multicolumn{2}{|c|}{$\begin{array}{c}\text { cis 1,2- } \\
\text { Dichloroethene }\end{array}$} & \multirow{2}{*}{$\begin{array}{c}\begin{array}{c}1,1 \\
\text { Dichloro- } \\
\text { ethene }\end{array} \\
- \\
\begin{array}{c}\text { Ground } \\
\text { water }\end{array}\end{array}$} & \multirow{2}{*}{$\begin{array}{c}\begin{array}{c}\text { Vinyl } \\
\text { chloride }\end{array} \\
\begin{array}{c}\text { Ground } \\
\text { water }\end{array}\end{array}$} & \multicolumn{5}{|c|}{ Field measurements } \\
\hline & & Vapor & $\begin{array}{l}\text { Ground } \\
\text { water }\end{array}$ & Vapor ${ }^{\star \star}$ & $\begin{array}{l}\text { Ground } \\
\text { water }\end{array}$ & & & $\begin{array}{c}\text { Temperature } \\
\text { in degrees } \\
\text { Celsius }\end{array}$ & $\begin{array}{c}\text { Specific } \\
\text { conductance } \\
\text { in } \\
\text { microsie- } \\
\text { mens per } \\
\text { centimeter at } \\
25 \text { degrees } \\
\text { Celsius }\end{array}$ & $\begin{array}{l}\mathrm{pH} \text { in } \\
\text { standard } \\
\text { units }\end{array}$ & $\begin{array}{l}\text { Dissolved } \\
\text { oxygen, } \\
\text { in } \\
\text { milligrams } \\
\text { per liter }\end{array}$ & $\begin{array}{c}\text { Gradient } \\
\text { between } \\
\text { stream and } \\
\text { ground } \\
\text { water in feet } \\
\text { per feet }\end{array}$ \\
\hline $\begin{array}{l}\text { OT } 2850 \\
\text { lew }\end{array}$ & $11 / 17 / 97$ & 1,065 & $* 113$ & yes, high & $\mathrm{ns}$ & $<1$ & ns & 10.4 & 331 & - & - & +0.05 \\
\hline OT 2850 & $11 / 17 / 97$ & trace & 39 & nd & 23 & $<1$ & 3.6 & 9.5 & 335 & 6.1 & 0.6 & +.09 \\
\hline $\begin{array}{c}\text { OT } 2850 \\
\text { rew }\end{array}$ & $11 / 17 / 97$ & 77 & 30 & yes, high & 26 & $<1$ & $<1$ & 9.8 & 330 & 6.6 & 2.2 & +.19 \\
\hline $\begin{array}{c}\text { OT } 2900 \\
\text { lew }\end{array}$ & $11 / 17 / 97$ & $>30,000$ & 1,100 & yes, high & $<1$ & 2,100 & $<1$ & 9.6 & 322 & 6.4 & .6 & +.03 \\
\hline OT 2900 & $11 / 17 / 97$ & 789 & 2,900 & nd & 1,200 & $<1$ & $<1$ & 9.1 & 349 & 6.3 & .6 & +.06 \\
\hline $\begin{array}{c}\text { OT } 2900 \\
\text { rew }\end{array}$ & $11 / 17 / 97$ & $<25$ & 2,700 & yes, high & 1,000 & $<1$ & $<1$ & 9.6 & 350 & 6.4 & 5.1 & +.07 \\
\hline $\begin{array}{l}\text { Old } \\
\text { Tannery } \\
\text { Brook } \\
\text { at OT } \\
2850\end{array}$ & $11 / 17 / 97$ & ns & ns & ns & ns & ns & ns & 2.3 & 220 & 7.6 & 13.4 & na \\
\hline $\begin{array}{l}\text { Old } \\
\text { Tannery } \\
\text { Brook } \\
\text { at OT } \\
2900\end{array}$ & $11 / 17 / 97$ & $\mathrm{~ns}$ & ns & ns & ns & ns & $\mathrm{ns}$ & 3.0 & 213 & 7.3 & 12.9 & na \\
\hline
\end{tabular}


Table 8. Detections of volatile organic compounds in ground-water samples collected May to September 1998 in the Nutmeg Valley study area, Wolcott and Waterbury, Connecticut

[All concentrations in micrograms per liter (parts per billion). Only detected compounds shown. <, less than specified reporting limit; e, estimated value below the calibration range; mb, monitoring well in bedrock aquifer; md, monitoring well screened in deepest part of surficial aquifer; mi, monitoring well screened in intermediate part of surficial aquifer; ms, monitoring well screened near the water table in the surficial aquifer; bs, supply wells at a business that tap bedrock aquifer; TCA, 1,1,1-trichloroethane; TCE, trichloroethene; PCE, tetrachloroethene; $c$ 1,2-DCE, cis 1,2-dichloroethene;

DCA, 1,1 dichloroethane; USEPA MCL (in bold), U.S. Environmental Protection Agency maximum contaminant level for drinking water; - , no MCL established]

\begin{tabular}{|c|c|c|c|c|c|c|c|c|c|c|c|c|c|c|}
\hline $\begin{array}{l}\text { USGS } \\
\text { local well } \\
\text { number } \\
\text { (locations } \\
\text { on pl. 1, } \\
\text { fig. 24) }\end{array}$ & Well type & TCA & TCE & PCE & $\begin{array}{l}c 1,2- \\
\text { DCE }\end{array}$ & DCA & $\begin{array}{l}\text { Chloro- } \\
\text { form }\end{array}$ & $\begin{array}{c}\text { Tetra- } \\
\text { hydrofu- } \\
\text { ran }\end{array}$ & $\begin{array}{l}\text { Ben- } \\
\text { zene }\end{array}$ & $\begin{array}{l}\text { Ethyl } \\
\text { Ether }\end{array}$ & $\begin{array}{l}\text { Chloro- } \\
\text { benzene }\end{array}$ & $\begin{array}{c}\text { 1,4- } \\
\text { Dichloro- } \\
\text { benzene }\end{array}$ & $\begin{array}{l}\text { Chloro- } \\
\text { ethane }\end{array}$ & $\begin{array}{c}\text { 1,1,2- } \\
\text { Trichloro, } \\
\text { 1,2,2- } \\
\text { trifluoro- } \\
\text { ethane }\end{array}$ \\
\hline $\begin{array}{r}\text { USEPA } \\
\mathrm{MCL}\end{array}$ & - & 200 & 5 & 5 & 70 & - & - & - & 5 & - & 100 & 75 & - & - \\
\hline WB 404 & $\mathrm{md}$ & 2 & 7 & 8 & $<1$ & $<1$ & 1 & 10 & $<1$ & $<3$ & $<1$ & $<1$ & $<1$ & 1 \\
\hline WB 405 & $\mathrm{mi}$ & $<1$ & $<1$ & $<1$ & $<1$ & $<1$ & 2 & $<7$ & $<1$ & $<3$ & $<1$ & $<1$ & $<1$ & $<1$ \\
\hline WB 407 & $\mathrm{mb}$ & 4 & 9 & 13 & $<1$ & $<1$ & $<1$ & $<7$ & $<1$ & $<3$ & $<1$ & $<1$ & $<1$ & 1 \\
\hline WC 49 & $\mathrm{mb}$ & $<1$ & $<1$ & $<1$ & $<1$ & $<1$ & $<1$ & $<7$ & 2 & 17 & 4 & 2 & 2 & $<1$ \\
\hline WC 80 & $\mathrm{md}$ & 1 & $<1$ & $<1$ & $<1$ & $<1$ & $<1$ & $<7$ & $<1$ & $<3$ & $<1$ & $<1$ & $<1$ & $<1$ \\
\hline WC 83 & $\mathrm{mb}$ & 2 & 2 & le & $<1$ & $<1$ & $<1$ & $<7$ & $<1$ & $<3$ & $<1$ & $<1$ & $<1$ & $<1$ \\
\hline WC 84 & md & $<1$ & $<1$ & $<1$ & $<1$ & $<1$ & le & $<7$ & $<1$ & $<3$ & $<1$ & $<1$ & $<1$ & $<1$ \\
\hline WC 87 & $\mathrm{md}$ & $<1$ & $<1$ & $<1$ & $<1$ & $<1$ & le & $<7$ & $<1$ & $<3$ & $<1$ & $<1$ & $<1$ & $<1$ \\
\hline WC 89 & $\mathrm{~ms}$ & $<1$ & $<1$ & $<1$ & $<1$ & $<1$ & $<1$ & $<7$ & 2 & $<3$ & $<1$ & $<1$ & $<1$ & $<1$ \\
\hline WC 95 & $\mathrm{~ms}$ & 2 & $<i$ & le & 2 & 2 & $<1$ & $<7$ & $<1$ & $<3$ & $<1$ & $<1$ & $<1$ & $<1$ \\
\hline WC 100 & $\mathrm{mb}$ & $<1$ & $<1$ & $<1$ & $<1$ & $<1$ & $<1$ & $<7$ & $<1$ & 8 & 1e & $<1$ & $<1$ & $<1$ \\
\hline WC 101 & bs & $<1$ & 10 & $<1$ & le & $<1$ & $<1$ & $<7$ & $<1$ & $<3$ & $<1$ & $<1$ & $<1$ & $<1$ \\
\hline WC 103 & bs & $<1$ & $<1$ & $<1$ & $<1$ & $<1$ & $<1$ & $4 e$ & $<1$ & $3 e$ & $<1$ & $<1$ & $<1$ & $<1$ \\
\hline
\end{tabular}


The USGS sampled seven newly installed wells in the bedrock aquifer along with six bedrock-supply wells in the Tosun Rd. residential area, six bedrocksupply wells at businesses, one former supply well, and three bedrock monitoring wells installed by private consultants for other site investigations. VOCs were detected primarily in bedrock wells that are in the downgradient part of the Nutmeg Valley study area (fig. 24). The wells WC 83 and WB 407 are downgradient from areas where past VOC contamination of ground water in the bedrock aquifer has been documented. The compounds detected in these wells included TCA, TCE, and PCE. These three VOCs were the most frequently detected contaminants in the bedrock supply wells sampled in the Nutmeg Valley study area (Stone and others, 1997).

Water-level measurements indicate that the water levels in bedrock wells WC 83 and WB 407 are higher than the water levels in the wells (WC 80 and WB 404 respectively) screened in the surficial aquifer, just above the bedrock, in each well cluster. This indicates an upward gradient from the bedrock to the overlying surficial aquifer and that ground water from the bedrock aquifer containing VOCs is possibly discharging to the surficial aquifer. Samples from WC 80 contained TCA, and samples from WB 404 contained TCA, TCE, and PCE.

Many samples from wells in the bedrock aquifer contained no VOCs at concentrations above the reporting limit. No VOCs were present in the six supply wells sampled in the Tosun Rd. residential area or in samples from two businesses located adjacent to the residential subdivision. However, some samples collected in the residential area by the Chesprocott Health District during 1998 contained the gasoline additive MTBE (Lorraine DeNicola, Director of Environmental Health, Chesprocott Health District, written commun., Sept. 14, 1998). MTBE has been frequently detected in ground water and stormwater runoff since it was introduced as a gasoline additive to improve air quality. The source of low concentrations of MTBE in ground water has been attributed to its common presence in urban air and stormwater (Lopes and Bender, 1998). MTBE analysis was not included in the USEPA method used in this investigation.

Samples were collected by the Chesprocott Health District at 35 residential and commercial properties. No VOCs were detected above MCLs in any of the samples. The compounds MTBE, chloroform, toluene, PCE, TCE, TCA, and methylene chloride were detected at low concentrations in samples from some wells (Lorraine DeNicola, Director of Environmental Health, Chesprocott Health District, written commun., Sept. 14, 1998). The reporting limit for VOCs for the samples collected by the Chesprocott Health District was $0.5 \mu \mathrm{g} / \mathrm{L}$; this is lower than the $1-\mu \mathrm{g} / \mathrm{L}$ reporting limit for the samples collected by the USGS and analyzed by the USEPA.

Samples collected from wells in the Swiss Lane area, downgradient of the North End Disposal Area, included three supply wells located at businesses (WC $102,103,104)$, one sample collected from a spring near WC 104, and two bedrock monitoring wells-one well installed by the USGS at the end of Swiss Lane (WC 100 ) and one existing monitoring well located immediately downgradient from the North End Disposal Area (WC 49, also known as MW-J). Several of these samples contained the compound ethyl ether at concentrations ranging from the reporting limit of $3 \mu \mathrm{g} / \mathrm{L}$ to 17 $\mu \mathrm{g} / \mathrm{L}$. Ethyl ether was previously detected in samples collected by the Chesprocott Health District during 1991 (Stone and others, 1997) from well WC 104, in samples from a former supply well at Raypax Inc., and at Richards Metals. The highest concentration of ethyl ether was present in samples from well WC 49, adjacent to the North End Disposal Area. Samples from WC 49 also contained detectable concentrations of benzene, chlorobenzene, 1,4 dichlorobenzene, and chloroethane. These compounds, with the exception of ethyl ether (not included in previous analyses), were previously detected in samples from WC 49 . The compounds benzene, chlorobenzene, 1,4 dichlorobenzene also were previously detected in samples from the landfill leachate-collection system as part of the regular quarterly monitoring program for closure of the North End Disposal Area (Fuss and O'Neill, 1997, 1998a,b). Chlorobenzene also was detected below the calibration range in samples from WC 100.

\section{Inorganic Constituents}

Water samples collected by the USGS also were analyzed for major anions, selected trace metals and cations, and cyanide. Temperature, $\mathrm{pH}$, specific conductance, and dissolved oxygen also were measured at each well during or immediately after collection of water samples (table 9). Qualitative measurements of turbidity and oxidation-reduction potential also were made during sampling.

Analytical results for major ions and field measurements were grouped by well type and location so that comparison of selected constituents could be made (table 9). The groups included monitoring wells installed in bedrock aquifers, supply wells at businesses, supply wells at residences on Tosun Rd., wells and a spring near the North End Disposal Area, and wells screened in the bottom, middle, and top of the surficial aquifer. 


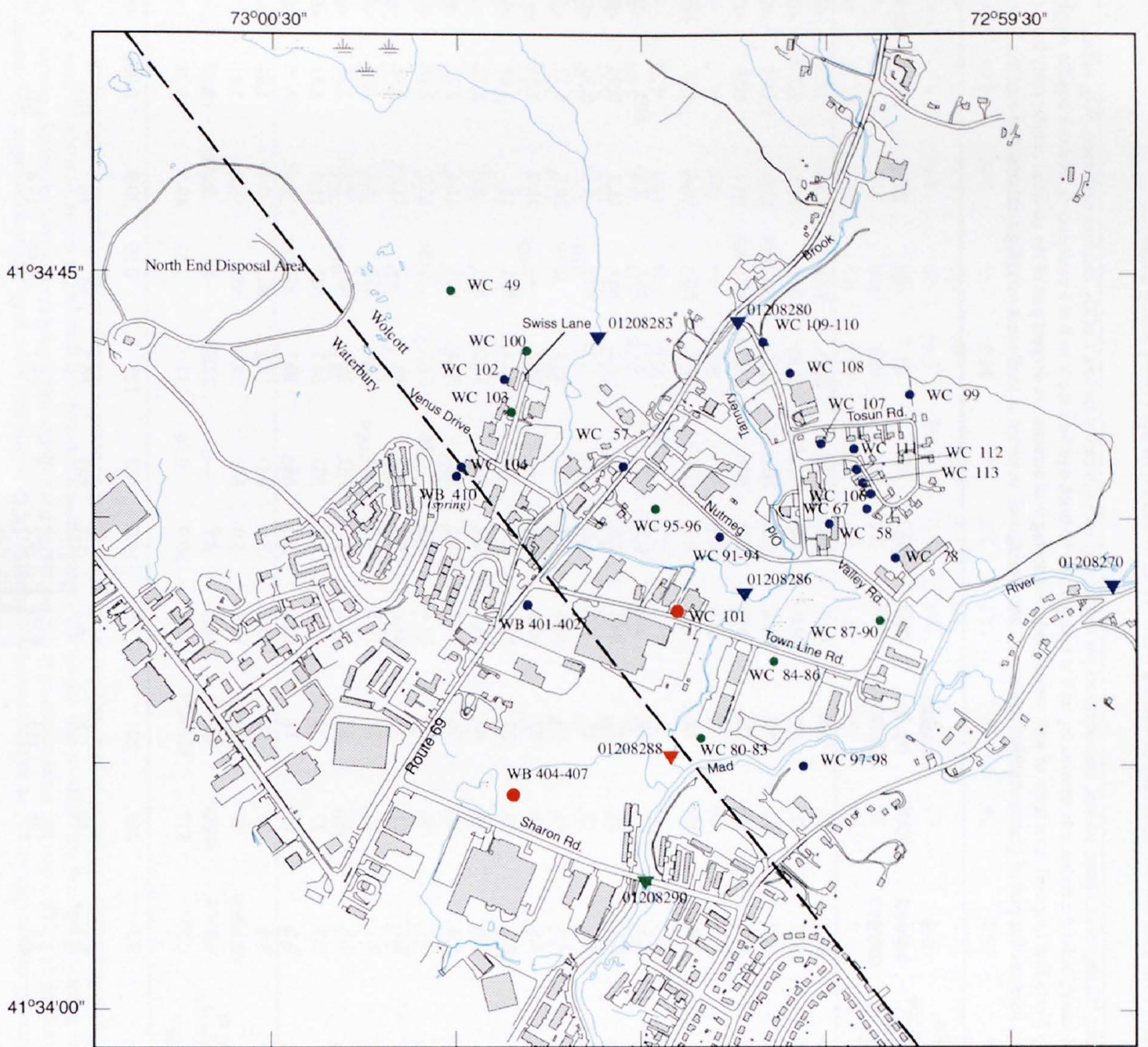

Base from U.S. Army Corps of Engineers, 1993, 1997

Scale 1:2,400

Projection: State Plane Feet, Zone 3526

Surface-water Well/well cluster/ EXPLANATION

$\begin{array}{lccccccc}0 & 400 & 800 & 1200 & 1600 & 2000 & \text { FEET } \\ 0 & 100 & 200 & 300 & 400 & 500 & \text { METERS }\end{array}$
location spring location

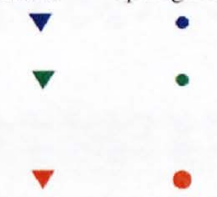

01208270
Volatile organic compounds not detected

Volatile organic compound(s) detected below U.S. Environmental Protection Agency maximum contaminant level

Volatile organic compound(s) detected at or above U.S. Environmental Protection Agency maximum contaminant level for drinking water

U.S. Geological Survey well identifier

U.S. Geological Survey surface-water site identifier

Figure 24. Detections of volatile organic compounds in wells sampled May to September 1998 in the Nutmeg Valley study area, Wolcott and Waterbury, Connecticut. 
Table 9. Field measurements and concentrations of major ions and cyanide in samples collected from wells in the Nutmeg Valley study area,

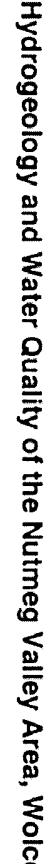

Wolcott and Waterbury, Connecticut

All units in micrograms per liter unless otherwise noted; Temp., temperature; ${ }^{\circ} \mathrm{C}$, degrees Celsius; $\mu \mathrm{S} / \mathrm{cm}$, microsiemens per centimeter; $\mathrm{HCO}_{3}$, bicarbonate ion; $\mathrm{CaCO}_{3}$, calcium carbonate, $\mathrm{SO}_{4,}$ sulfate;

$\mathrm{NO}_{3}$, nitrate; med, median (medians in bold type); $\mathrm{ND}$, not detected; e, estimated; well type codes: mb, monitoring well in bedrock; bs, bedrock aquifer supply well at a business; ds, bedrock aquifer supply

well at a residence; NEDA, ground-water samples collected near Waterbury North End Disposal Area (type of well varies); md, monitoring well screened in deepest part of the surficial aquifer (may be

screened in till or glacial stratified deposits); mi, monitoring well screened in intermediate part of glacial stratified aquifer; ms, monitoring well screened in shallowest part of glacial stratified aquifer;

-, not applicable]

\begin{tabular}{|c|c|c|c|c|c|c|c|c|c|c|c|c|c|c|c|c|}
\hline $\begin{array}{l}\text { USGS local } \\
\text { identifier } \\
\text { (location } \\
\text { shown on } \\
\text { pl. 1) }\end{array}$ & Type & $\begin{array}{c}\text { Sample } \\
\text { date }\end{array}$ & $\begin{array}{l}\text { Temp. } \\
\text { in }{ }^{\circ} \mathrm{C}\end{array}$ & $\begin{array}{c}\text { pH } \\
\text { (stan- } \\
\text { dard } \\
\text { units) }\end{array}$ & $\begin{array}{c}\text { Specific. } \\
\text { conductance } \\
\mu \mathrm{S} / \mathrm{cm} \text { at } \\
25^{\circ} \mathrm{C}\end{array}$ & $\begin{array}{l}\text { Dis- } \\
\text { solved } \\
\text { oxygen }\end{array}$ & $\mathrm{HCO}_{3}$ & $\begin{array}{l}\text { Alkalin- } \\
\text { ity, as } \\
\mathrm{CaCO}_{3}\end{array}$ & $\mathrm{Ca}$ & $\mathrm{Mg}$ & $\mathbf{F}$ & $\mathrm{Cl}$ & $\mathrm{Br}$ & $\mathrm{SO}_{4}$ & $\mathrm{NO}_{3}$ & Cyanide \\
\hline WC 83 & $\mathrm{mb}$ & $6 / 26 / 98$ & 12.1 & 7.1 & 250 & 2.3 & 77 & 63 & 30.9 & 7.6 & ND & 26.3 & ND & 12.5 & 5.86 & $<0.04$ \\
\hline WC 90 & $\mathrm{mb}$ & $6 / 25 / 98$ & 12.2 & 8.6 & 157 & 2.7 & 52 & 47 & 22.0 & 2.4 & $0.06 e$ & 11.4 & ND & 11.5 & 2.2 & $<0.04$ \\
\hline WC 94 & $\mathrm{mb}$ & $6 / 26 / 98$ & 15.5 & 6.6 & 196 & 8.3 & 48 & 39 & 22.4 & 2.2 & ND & 26.3 & ND & 13.3 & 3.01 & $<0.04$ \\
\hline $\begin{array}{l}\text { WC } 96 \text { shal- } \\
\text { low sample }\end{array}$ & $\mathrm{mb}$ & $6 / 18 / 98$ & 12.8 & 5.9 & 178 & 8.9 & 18 & 15 & 9.8 & 2.2 & ND & 36.2 & ND & 10.4 & 1.88 & $<0.04$ \\
\hline $\begin{array}{l}\text { WC } 96 \text { deep } \\
\text { sample }\end{array}$ & $\mathrm{mb}$ & $6 / 18 / 98$ & 15.6 & 6.0 & 181 & 3.9 & 18 & 15 & 9.3 & 2.1 & ND & 37.2 & ND & 10.4 & 0.95 & $<0.04$ \\
\hline WC 99 & $\mathrm{mb}$ & $6 / 15 / 98$ & 10.5 & 6.5 & 62 & 11.5 & 23 & 19 & 8.5 & 0.8 & $\mathrm{ND}$ & 1.73 & ND & 7.85 & ND & $<0.04$ \\
\hline WC 108 & $\mathrm{mb}$ & $7 / 07 / 98$ & 13.1 & 6.5 & 88 & 10.1 & 33 & 27 & 10.3 & 2.6 & $\mathrm{ND}$ & 1.1 & ND & 11.2 & 0.96 & $<0.04$ \\
\hline WC 109 & $\mathrm{mb}$ & $7 / 07 / 98$ & 11.7 & 6.4 & 57 & 4.6 & 19 & 15 & 5.2 & 1.0 & ND & 1.73 & ND & 5.83 & 0.35 & $<0.04$ \\
\hline WB 407 & $\mathrm{mb}$ & $6 / 02 / 98$ & 10.5 & 6.7 & 314 & 4.0 & 81 & 66 & 40.2 & 6.7 & ND & 35.1 & $0.09 \mathrm{e}$ & 20.8 & 9.27 & $<0.04$ \\
\hline med mb & $\mathrm{mb}$ & & 12.2 & 6.5 & 178 & 4.6 & 33 & 27 & 10.3 & 2.2 & - & 26.3 & - & 11.2 & 1.88 & - \\
\hline WC 57 & bs & $6 / 10 / 98$ & 15.5 & 6.3 & 150 & 8.3 & 33 & 27 & 15.1 & 2.0 & ND & 16.4 & $\mathrm{ND}$ & 12 & $5: 04$ & $<0.04$ \\
\hline WC 58 & bs & $7 / 09 / 98$ & 13.2 & 6.7 & 238 & 5.8 & 54 & 45 & 26.7 & 6.8 & ND & 38.6 & ND & 6.67 & 5.78 & $<0.04$ \\
\hline WC 78 & bs & $7 / 23 / 98$ & 14.2 & 6.9 & 262 & 5.6 & 68 & 56 & 35.2 & 6.2 & ND & 39.4 & ND & 11.1 & 2.71 & $<0.04$ \\
\hline WC 101 & bs & $7 / 06 / 98$ & 14.9 & 6.8 & 314 & 0.7 & 68 & 56 & 19.4 & 3.8 & 0.26 & 51.5 & $0.05 e$ & 15.7 & 2.79 & $<0.08$ \\
\hline med bs & bs & & 14.5 & 6.8 & 250 & 5.7 & 61 & 51 & 23.1 & 5.0 & - & 39 & - & 11.55 & 3.91 & - \\
\hline WC 67 & ds & $7 / 06 / 98$ & 15.0 & 6.9 & 164 & 9.7 & 45 & 37 & 19.1 & 4.0 & ND & 21.6 & ND & 8.87 & 1.86 & $<0.08$ \\
\hline WC 106 & ds & $6 / 10 / 98$ & 11.7 & 6.6 & 183 & 7.6 & 45 & 37 & 18.6 & 5.8 & ND & 26.6 & ND & 7.38 & 2.88 & $<0.04$ \\
\hline WC 107 & ds & $6 / 10 / 98$ & 11.7 & 6.2 & 181 & 9.3 & 37 & 30 & 18.5 & 4.1 & ND & 24.7 & $N D$ & 11.8 & 4.51 & $<0.04$ \\
\hline WC 111 & ds & $7 / 09 / 98$ & 13.4 & 6.1 & 125 & 8.5 & 23 & 19 & 10.1 & 2.5 & ND & 19.7 & ND & 9.48 & 2.15 & $<0.04$ \\
\hline WC 112 & ds & $7 / 09 / 98$ & 13.1 & 6.5 & 144 & 8.6 & 35 & 29 & 15.1 & 3.0 & ND & 19.2 & ND & 9.49 & 1.91 & $<0.04$ \\
\hline WC 113 & ds & $7 / 09 / 98$ & 12.2 & 6.6 & 165 & 7.3 & 43 & 35 & 17.5 & 5.0 & ND & 21.7 & ND & 8.04 & 2.41 & $<0.04$ \\
\hline med ds & $\mathrm{ds}$ & & 12.7 & 6.5 & 164.5 & 8.5 & 40 & 33 & 18.0 & 4.1 & - & 21.65 & - & 9.175 & 2.28 & - \\
\hline WC 49 & $\begin{array}{l}\text { NEDA } \\
\mathrm{mb}\end{array}$ & $9 / 03 / 98$ & 12.3 & 7.0 & 1602 & 0.3 & 537 & 440 & 174.0 & 30.9 & 0.96 & 247 & 1.43 & 49.7 & 1.34 & $<0.04$ \\
\hline WC 100 & $\begin{array}{l}\text { NEDA } \\
\mathrm{mb}\end{array}$ & $6 / 25 / 98$ & 10.9 & 6.3 & 803 & 3.7 & 245 & 201 & 111.0 & 14.0 & ND & 128 & 0.59 & 20.9 & $0.06 \mathrm{a}$ & $<0.04$ \\
\hline WC 102 & $\begin{array}{l}\text { NEDA } \\
\text { bs }\end{array}$ & $6 / 09 / 98$ & 11.5 & 5.5 & 91 & 8.1 & 10 & 8 & 8.2 & 1.2 & ND & 10.3 & ND & 16 & $N D$ & $<0.04$ \\
\hline WC 103 & $\begin{array}{l}\text { NEDA } \\
\text { bs }\end{array}$ & $6 / 09 / 98$ & 13.2 & 6.6 & 677 & 3.3 & 226 & 185 & 92.6 & 9.2 & ND & 98.1 & 0.44 & 19.6 & ND & $<0.04$ \\
\hline WC 104 & $\begin{array}{l}\text { NEDA } \\
\text { bs }\end{array}$ & $6 / 09 / 98$ & 15.9 & 6.2 & 481 & 5.1 & 134 & 110 & 63.0 & 7.0 & 0.19 & 61.7 & 0.39 & 38.3 & 0.73 & $<0.04$ \\
\hline
\end{tabular}


Table 9. Field measurements and concentrations of major ions and cyanide in samples collected from wells in the Nutmeg Valley study area, Wolcott and Waterbury, Connecticut--Continued

[All units in micrograms per liter unless otherwise noted; Temp., temperature; ${ }^{\circ} \mathrm{C}$, degrees Celsius; $\mu \mathrm{S} / \mathrm{cm}$, microsiemens per centimeter; $\mathrm{HCO}_{3}$, bicarbonate ion; $\mathrm{CaCO}_{3}$, calcium carbonate, $\mathrm{SO}_{4}$, sulfate; $\mathrm{NO}_{3}$, nitrate; med, median (medians in bold type); $\mathrm{ND}$, not detected; e, estimated; well type codes: mb, monitoring well in bedrock; bs, bedrock aquifer supply well at a business; ds, bedrock aquifer supply well at a residence; NEDA, ground-water samples collected near Waterbury North End Disposal Area (type of well varies); md, monitoring well screened in deepest part of the surficial aquifer (may be screened in till or glacial stratified deposits); mi, monitoring well screened in intermediate part of glacial stratified aquifer; ms, monitoring well screened in shallowest part of glacial stratified aquifer; —, not applicable]

\begin{tabular}{|c|c|c|c|c|c|c|c|c|c|c|c|c|c|c|c|c|}
\hline $\begin{array}{l}\text { USGS local } \\
\text { identifier } \\
\text { (location } \\
\text { shown on } \\
\text { pl. 1) }\end{array}$ & Type & $\begin{array}{c}\text { Sample } \\
\text { date }\end{array}$ & $\begin{array}{l}\text { Temp. } \\
\text { in }{ }^{\circ} \mathrm{C}\end{array}$ & $\begin{array}{l}\text { pH } \\
\text { (stan- } \\
\text { dard } \\
\text { units) }\end{array}$ & $\begin{array}{l}\text { Specific. } \\
\text { conductance } \\
\mu \mathrm{S} / \mathrm{cm} \text { at } \\
25^{\circ} \mathrm{C}\end{array}$ & $\begin{array}{l}\text { Dis- } \\
\text { solved } \\
\text { oxygen }\end{array}$ & $\mathrm{HCO}_{3}$ & $\begin{array}{l}\text { Alkalin- } \\
\text { ity, as } \\
\mathrm{CaCO}_{3}\end{array}$ & $\mathrm{Ca}$ & $\mathrm{Mg}$ & $F$ & $\mathrm{Cl}$ & $\mathrm{Br}$ & $\mathrm{SO}_{4}$ & $\mathrm{NO}_{3}$ & Cyanide \\
\hline WB 410 & $\begin{array}{l}\text { NEDA } \\
\text { spring }\end{array}$ & $6 / 09 / 98$ & 13.9 & 6.9 & 422 & 9.5 & 82 & 67 & 39.4 & 10.2 & ND & 40 & 0.31 & 74.8 & $\mathrm{ND}$ & $<0.04$ \\
\hline med NEDA & NEDA & & 12.8 & 6.4 & 579 & 4.4 & 180 & 148 & 77.8 & 9.7 & - & 79.9 & 0.415 & 29.6 & - & - \\
\hline WC 80 & md & $6 / 16 / 98$ & 11.7 & 6.6 & 276 & 1.3 & 66 & 54 & 10.8 & 3.1 & $0.06 \mathrm{a}$ & 44.4 & ND & 10.4 & 1.92 & $<0.04$ \\
\hline WC 84 & $\mathrm{md}$ & $6 / 29 / 98$ & 12.0 & 6.8 & 227 & 3.0 & 66 & 54 & 23.7 & 6.7 & ND & 29.8 & ND & 8.95 & 3.77 & $<0.04$ \\
\hline WC 87 & md & $6 / 03 / 98$ & 11.0 & 6.0 & 120 & 2.0 & 34 & 28 & 10.8 & 2.6 & ND & 8.16 & ND & 12.4 & 1.02 & $<0.04$ \\
\hline WC 91 & $\mathrm{md}$ & $6 / 22 / 98$ & 12.5 & 6.2 & 241 & 9.1 & 29 & 24 & 10.2 & 2.4 & $\mathrm{ND}$ & 48.3 & ND & 11.4 & 3.89 & $<0.04$ \\
\hline WC 98 & $\mathrm{md}$ & $5 / 29 / 98$ & 12.7 & 6.2 & 115 & 4.9 & 35 & 29 & 11.5 & 2.9 & ND & 6.28 & ND & 11.6 & 1.52 & $<0.04$ \\
\hline WB 402 & md & $7 / 01 / 98$ & 13.7 & 5.5 & 351 & 10.4 & 6 & 5 & 13.0 & 2.8 & $\mathrm{ND}$ & 82.3 & ND & 13.5 & 18.3 & $<0.08$ \\
\hline WB 404 & $\mathrm{md}$ & $6 / 01 / 98$ & 12.3 & 7.4 & 198 & 1.9 & 62 & 51 & 19.6 & 5.8 & 0.16 & 29.8 & $0.07 \mathrm{e}$ & 7.1 & 2.92 & $<0.04$ \\
\hline med md & md & & 12.3 & 6.2 & 227 & 3.0 & 35 & 29 & 11.5 & 2.9 & - & 29.8 & - & 11.4 & 2.92 & - \\
\hline WC 81 & $\mathrm{mi}$ & $6 / 16 / 98$ & 11.9 & 6.2 & 225 & 0.3 & 40 & 33 & 14.8 & 4.1 & ND & 34.8 & $0.05 e$ & 17 & 1.78 & $<0.04$ \\
\hline WC 85 & $\mathrm{mi}$ & $6 / 29 / 98$ & 11.2 & 6.0 & 268 & 3.4 & 34 & 28 & 17.2 & 5.1 & ND & 54.2 & ND & 10.7 & 3.81 & $<0.04$ \\
\hline WC 88 & $\mathrm{mi}$ & $6 / 03 / 98$ & 10.3 & 5.7 & 93 & 0.1 & 22 & 18 & 7.4 & 1.9 & ND & 6.39 & ND & 11.4 & 1.09 & $<0.04$ \\
\hline WC 92 & $\mathrm{mi}$ & $6 / 22 / 98$ & 13.1 & 6.2 & 290 & 6.7 & 39 & 32 & 11.3 & 2.7 & $0.05 \mathrm{e}$ & 59.9 & ND & 10.7 & 4.54 & 0.052 \\
\hline WB 405 & $\mathrm{mi}$ & $6 / 01 / 98$ & 15.1 & 7.7 & 160 & 5.8 & 47 & 39 & 9.5 & 4.0 & 0.28 & 11.6 & ND & 14.3 & ND & $<0.04$ \\
\hline med mi & & & 11.9 & 6.2 & 225 & 3.4 & 39 & 32 & 11.3 & 4.0 & - & 34.8 & - & 11.4 & 1.78 & - \\
\hline WC 82 & $\mathrm{~ms}$ & $6 / 16 / 98$ & 12.8 & 5.6 & 156 & 5.0 & 26 & 21 & 16.5 & 5.4 & ND & 5.38 & $0.06 \mathrm{e}$ & 31 & 12 & $<0.04$ \\
\hline WC 86 & $\mathrm{~ms}$ & $6 / 29 / 98$ & 17.0 & 6.5 & 192 & 1.4 & 74 & 61 & 18.3 & 6.9 & 0.18 & 23.2 & $0.06 \mathrm{e}$ & 0.13 & ND & $<0.04$ \\
\hline WC 89 & $\mathrm{~ms}$ & $6 / 03 / 98$ & 9.4 & 5.7 & 147 & 0.1 & 30 & 24 & 10.9 & 3.4 & $N D$ & 22.3 & ND & 9.05 & 0.16 & $<0.04$ \\
\hline WC 93 & $\mathrm{~ms}$ & $6 / 22 / 98$ & 13.7 & 6.0 & 550 & 0.0 & 127 & 104 & 23.3 & 6.7 & ND & 105 & $0.08 \mathrm{e}$ & 8.69 & 0.16 & $<0.04$ \\
\hline WC 95 & $\mathrm{~ms}$ & $6 / 18 / 98$ & 14.3 & 5.8 & 231 & 5.6 & 30 & 24 & 12.3 & 2.7 & $0.07 \mathrm{e}$ & 46.4 & ND & 11.9 & 2.26 & $<0.04$ \\
\hline WC 97 & $\mathrm{~ms}$ & $5 / 29 / 98$ & 11.8 & 6.3 & 164 & 6.0 & 38 & 31 & 14.9 & 3.5 & $\mathrm{ND}$ & 14.8 & ND & 12.5 & 8.39 & $<0.04$ \\
\hline WC 110 & $\mathrm{~ms}$ & $7 / 07 / 98$ & 13.8 & 5.9 & 48 & 9.2 & 10 & 8 & 4.3 & 0.6 & ND & 1.76 & ND & 6.66 & 0.88 & $<0.04$ \\
\hline WB 401 & $\mathrm{~ms}$ & $7 / 01 / 98$ & 16.5 & 6.9 & 123 & 0.4 & 62 & 50 & 9.9 & 5.0 & $0.07 \mathrm{e}$ & 5.99 & ND & 3.39 & 0.5 & $<0.08$ \\
\hline WB 406 & $\mathrm{~ms}$ & $6 / 01 / 98$ & 9.6 & 6.2 & 51 & 11.2 & & & 3.5 & 1.0 & ND & 2.09 & ND & 6.34 & 0.28 & $<0.04$ \\
\hline med ms & $\mathrm{ms}$ & & 13.7 & 6.0 & 156 & 5.0 & 34 & 28 & 12.3 & 3.5 & - & 14.8 & - & 8.69 & 0.69 & - \\
\hline $\begin{array}{l}\text { Undevel- } \\
\text { oped areas } \\
\text { (Grady and M }\end{array}$ & $\begin{array}{l}\text { ms } \\
\text { ullaney, } 1\end{array}$ & 10 & 11.0 & 6.1 & 61 & 8.5 & 16 & 13 & 5.0 & 1.6 & - & 3.8 & 0.015 & 8.15 & 0.21 & ND \\
\hline
\end{tabular}


With the exception of one sample, concentrations of major ions did not exceed any USEPA MCLs. Many samples from wells in the surficial aquifer did, however, show some degradation of ground-water quality caused by human activities. Water samples from well WB 402 contained concentrations of nitratenitrogen at $18.3 \mathrm{mg} / \mathrm{L}$, higher than the USEPA MCL of $10 \mathrm{mg} / \mathrm{L}$. Other samples collected also had elevated concentrations of nitrate and chloride with respect to ambient concentrations reported by Grady and Mullaney (1998) (table 9). Values reported by Grady and Mullaney are for shallow wells screened in glacial stratified deposits derived from crystalline bedrock in forested areas of New England. Comparisons may not be valid for bedrock aquifers, because it is expected that ion concentrations may be higher in wells open to crystalline bedrock aquifers than those screened in surficial aquifers, presumably because the contact time with geologic materials may be longer. Elevated concentrations of chloride in many samples are probably due to the runoff and infiltration of road salt used for winter deicing of roads and parking areas. Sources of elevated nitrate may be from runoff of lawn fertilizers, effluent from former septic systems, and leakage from sanitary sewer lines.

In general, the group of samples that had the highest measurements of specific conductance and alkalinity and the highest concentrations of chloride, bromide, sulfate, calcium, and magnesium were those collected adjacent to the Waterbury North End Disposal Area. The concentrations of bromide were much higher in this group of wells than in any other, and although the concentrations are not above MCLs, it may indicate that ground-water quality is affected by leachate from the landfill. The median bromide concentration for this set of wells was $0.42 \mathrm{mg} / \mathrm{L}$ but was generally detected at or below the reporting limit in ground-water samples from other parts of the study area. In addition, samples from this group of wells had the lowest nitrate concentrations.

Samples of landfill leachate collected by Fuss and O'Neill Inc. (1997, 1998a, b) had high specific conductance, alkalinity, and concentrations of chloride. It is likely that water containing high concentrations of dissolved solids originating at the North End Disposal Area has affected water quality in the Swiss Lane Area, which is located downgradient. There also have been instances of contamination of soil and ground water by VOCs at several businesses in this area (Stone and others, 1997); therefore, other local sources of contamina- tion by inorganic constituents cannot be completely ruled out. Samples from the supply well for Roann Electronics (WC 102), also located adjacent to the North End Disposal Area, showed little or no degradation in water quality. For example, the specific conductance of samples from well WC 102 was $91 \mu \mathrm{S} / \mathrm{cm}$ compared to $803 \mu \mathrm{S} / \mathrm{cm}$ at nearby well WC 100 , and $677 \mu \mathrm{S} / \mathrm{cm}$ at well WC 103. It is possible that well WC 102 is intersecting different fractures or a more local flow system than the other wells. The construction characteristics for well WC 102 are unknown.

Wells installed in the shallowest part of the surficial aquifer, with one exception, contained some of the lowest concentrations of dissolved inorganic constituents. One well in this group, WC 93, had a high specific conductance and elevated concentrations of chloride, which may be the result of runoff and infiltration of road salt-it is near an area where road runoff collects from uphill sources. Three bedrock wells (WC 99, WC 108, WC 109) on or downgradient from undeveloped properties had the lowest concentrations of major ions of any samples collected. Concentrations of major ions and trace elements indicate that water from these wells may resemble predevelopment concentrations in the bedrock aquifer.

Only one well (WC 92) on Nutmeg Valley Rd. contained detectable concentrations of cyanide. The concentration in samples from WC 92 was $0.05 \mathrm{mg} / \mathrm{L}$, which is below the USEPA MCL of $0.2 \mathrm{mg} / \mathrm{L}$. This well is near areas of former reported cyanide use (Metcalf and Eddy, 1992).

\section{Trace Elements}

Samples collected for trace elements did not exceed any USEPA MCLs (table 10); however, several samples exceeded USEPA Secondary Maximum Contaminant Levels (SMCLs) for iron and manganese. Iron and manganese are likely to be present naturally in ground water from the study area. Some elevated manganese concentrations may be due to the presence of rock containing manganese-rich minerals or sediment with manganese oxide coatings (Hem, 1985) underlying parts of the Nutmeg Valley study area. Other possible natural sources include wetland areas and buried swamp deposits beneath water bodies in the study area. Wilson and others (1974) reported concentrations of manganese in surficial aquifers up to $1.7 \mathrm{mg} / \mathrm{L}$ for surficial aquifers in the lower Housatonic River Basin and up to $0.34 \mathrm{mg} / \mathrm{L}$ in bedrock aquifers. Samples from well WC 49 (MW-J) adjacent to the North End Dis- 
posal Area had the highest concentration of manganese at $21,600 \mu \mathrm{g} / \mathrm{L}$, or $21.6 \mathrm{mg} / \mathrm{L}$. Fuss and O'Neill Inc. (1997, 1998a,b) reported that the landfill leachate from the North End Disposal Area contained concentrations of manganese ( 9.35 to $11.1 \mathrm{mg} / \mathrm{L}$ ), and iron (5.6 to 7.8 $\mathrm{mg} / \mathrm{L}$ ) in samples collected from April 1997 to January 1998. The elevated concentrations of manganese and iron reported in wells sampled in the Swiss Lane area likely result from downgradient migration of landfill leachate to this area. Concentrations of manganese and iron depend on sample $\mathrm{pH}$ and the local oxidationreduction potential. Manganese and iron may precipi- tate from ground water if the ground water encounters or mixes with waters containing higher dissolved oxygen (Hem, 1985). Conversely, reduced waters, such as those beneath a landfill, may be able to dissolve manganese and iron coatings from unconsolidated deposits or from the fracture surfaces of the underlying bedrock, causing high concentrations in downgradient waters. Elevated concentrations of iron may be present in situations similar to those associated with manganese.

Other factors that may affect the concentration of iron include the presence of bicarbonate and sulfate and bacterial reactions (Hem, 1985).

Table 10. Concentrations of dissolved trace elements detected in samples collected from wells in the Nutmeg Valley study area, Wolcott and Waterbury, Connecticut

[All units in micrograms per liter unless otherwise noted. $\mathrm{Al}$, aluminum; $\mathrm{Ba}$, barium; $\mathrm{Cu}$, copper; $\mathrm{Fe}$, iron; $\mathrm{Mn}$, manganese; $\mathrm{Ni}$, nickel, $\mathrm{V}$, vanadium; $\mathrm{Zn}$, zinc; <, less than specified reporting limit; well type codes: mb, monitoring well in bedrock; bs, bedrock aquifer supply well at a business; ds, bedrock aquifer supply well at a residence; NEDA, ground-water samples collected near Waterbury North End Disposal Area, type of well varies); md, monitoring well screened in deepest part of the surficial aquifer (may be screened in till or glacial stratified deposits); mi, monitoring well screened in intermediate part of glacial stratified aquifer; ms, monitoring well screened in shallowest part of glacial stratified aquifer]

\begin{tabular}{|c|c|c|c|c|c|c|c|c|c|c|}
\hline $\begin{array}{l}\text { USGS } \\
\text { local } \\
\text { identifier } \\
\text { (location } \\
\text { shown on } \\
\text { pl. 1) }\end{array}$ & $\begin{array}{l}\text { Well } \\
\text { type }\end{array}$ & $\begin{array}{c}\text { Date } \\
\text { sampled }\end{array}$ & Al & $\mathrm{Ba}$ & $\mathrm{Cu}$ & $\mathrm{Fe}$ & Mn & $\mathrm{NI}$ & v & $\mathrm{Zn}$ \\
\hline WC 83 & $\mathrm{mb}$ & $6 / 26 / 98$ & 5.4 & 5.9 & $<1.5$ & 42.5 & 10 & $<6$ & $<1.5$ & $<15$ \\
\hline WC 90 & $\mathrm{mb}$ & $6 / 25 / 98$ & 11.2 & 7.4 & $<1.5$ & 10.6 & 2.7 & $<6$ & 3.1 & $<15$ \\
\hline WC 94 & $\mathrm{mb}$ & $6 / 26 / 98$ & $<5$ & 3.2 & $<1.5$ & $<5$ & 2.9 & $<6$ & $<1.5$ & $<15$ \\
\hline $\begin{array}{l}\text { WC } 96 \\
\text { shallow } \\
\text { sample }\end{array}$ & $\mathrm{mb}$ & $6 / 18 / 98$ & $<5$ & 3.8 & $<1.5$ & 359 & 49.5 & $<6$ & $<1.5$ & $<1.5$ \\
\hline $\begin{array}{l}\text { WC } 96 \\
\text { deep } \\
\text { sample }\end{array}$ & $\mathrm{mb}$ & $6 / 18 / 98$ & $<5$ & 5.3 & $<1.5$ & 83.2 & 218 & $<6$ & $<1.5$ & 3.2 \\
\hline WC 99 & $\mathrm{mb}$ & $6 / 15 / 98$ & $<5$ & $<1.5$ & $<1.5$ & $<5$ & 10.2 & $<6$ & $<1.5$ & $<1.5$ \\
\hline WC 108 & $\mathrm{mb}$ & $7 / 07 / 98$ & $<5$ & 3.5 & 1.9 & $<5$ & $<1$ & $<6$ & $<1.5$ & 6 \\
\hline WC 109 & $\mathrm{mb}$ & $7 / 07 / 98$ & $<5$ & $<1.5$ & $<1.5$ & 40.9 & 22.8 & $<6$ & $<1.5$ & $<1.5$ \\
\hline WB 407 & $\mathrm{mb}$ & $6 / 02 / 98$ & $<10$ & 21.4 & 9.6 & 42.5 & 4.8 & $<6$ & $<1.5$ & $<12$ \\
\hline WC 57 & bs & $6 / 10 / 98$ & $<10$ & 6.2 & 13.9 & $<5$ & $<1$ & $<6$ & $<1.5$ & 27.2 \\
\hline WC 58 & bs & $7 / 09 / 98$ & $<5$ & 4.5 & 21 & $<5$ & 1 & $<6$ & $<1.5$ & 17.8 \\
\hline WC 78 & bs & $7 / 23 / 98$ & $<10$ & 1.9 & 7.1 & $<20$ & $<1$ & $<6$ & 1.6 & $<30$ \\
\hline WC 101 & bs & $7 / 06 / 98$ & $<5$ & 7.4 & $<1.5$ & 2,630 & 509 & $<6$ & $<1.5$ & 9.6 \\
\hline WC 67 & ds & $7 / 06 / 98$ & $<5$ & 6.6 & 37.7 & $<5$ & 3.1 & $<6$ & $<1.5$ & $<15$ \\
\hline WC 106 & ds & $6 / 10 / 98$ & $<10$ & 21.5 & 27.1 & $<5$ & $<1$ & $<6$ & $<1.5$ & $<12$ \\
\hline WC 107 & ds & $6 / 10 / 98$ & $<10$ & 1.6 & 10.3 & 12.1 & $<1$ & $<6$ & $<1.5$ & 65.8 \\
\hline WC 111 & ds & $7 / 09 / 98$ & $<5$ & 9.1 & 11.3 & $<5$ & $<1$ & $<6$ & $<1.5$ & 9.7 \\
\hline WC 112 & ds & $7 / 09 / 98$ & $<5$ & 13.5 & 14.3 & $<5$ & $<1$ & $<6$ & $<1.5$ & 11.4 \\
\hline WC 113 & ds & $7 / 09 / 98$ & $<5$ & 106 & 18.8 & $<5$ & $<1$ & $<6$ & $<1.5$ & 11.5 \\
\hline
\end{tabular}


Table 10. Concentrations of dissolved trace elements detected in samples collected from wells in the Nutmeg Valley study area, Wolcott and Waterbury, Connecticut--Continued

[All units in micrograms per liter unless otherwise noted. Al, aluminum; $\mathrm{Ba}$, barium; $\mathrm{Cu}$, copper; $\mathrm{Fe}$, iron; $\mathrm{Mn}$, manganese; $\mathrm{Ni}$, nickel, $\mathrm{V}$, vanadium; $\mathrm{Zn}$, zinc; <, less than specified reporting limit; well type codes: mb, monitoring well in bedrock; bs, bedrock aquifer supply well at a business; ds, bedrock aquifer supply well at a residence; NEDA, ground-water samples collected near Waterbury North End Disposal Area, type of well varies); md, monitoring well screened in deepest part of the surficial aquifer (may be screened in till or glacial stratified deposits); mi, monitoring well screened in intermediate part of glacial stratified aquifer; $\mathrm{ms}$, monitoring well screened in shallowest part of glacial stratified aquifer]

\begin{tabular}{|c|c|c|c|c|c|c|c|c|c|c|}
\hline $\begin{array}{c}\text { USGS } \\
\text { local } \\
\text { identifier } \\
\text { (location } \\
\text { shown on } \\
\text { pl. 1) }\end{array}$ & $\begin{array}{l}\text { Well } \\
\text { type }\end{array}$ & $\begin{array}{c}\text { Date } \\
\text { sampled }\end{array}$ & Al & $\mathrm{Ba}$ & $\mathrm{Cu}$ & $\mathrm{Fe}$ & Mn & $\mathrm{Ni}$ & $v$ & $\mathrm{Zn}$ \\
\hline WC 49 & NEDA mb & $9 / 03 / 98$ & 16 & 65.1 & $<1.5$ & 421 & 20,600 & $<15$ & $<1.5$ & $<30$ \\
\hline WC 100 & NEDA mb & $6 / 25 / 98$ & 10.4 & 45.3 & $<1.5$ & 3,340 & 352 & $<6$ & $<1.5$ & 9 \\
\hline WC 102 & NEDA bs & $6 / 09 / 98$ & 132 & 8.5 & 16.7 & $<5$ & 72.2 & $<6$ & $<1.5$ & 28.2 \\
\hline WC 103 & NEDA bs & $6 / 09 / 98$ & 10.4 & 38.7 & 10.1 & $<5$ & 3,240 & $<10$ & $<1.5$ & $<40$ \\
\hline WC 104 & NEDA bs & $6 / 09 / 98$ & $<10$ & 14.5 & 130 & $<5$ & 346 & $<10$ & $<1.5$ & 39.4 \\
\hline WB 410 & $\begin{array}{l}\text { NEDA } \\
\text { spring }\end{array}$ & $6 / 09 / 98$ & $<10$ & 10.6 & $<1.5$ & $<5$ & 116 & $<10$ & $<1.5$ & $<12$ \\
\hline WC 80 & $\mathrm{md}$ & $6 / 16 / 98$ & $<5$ & 7.5 & $<1.5$ & 8.1 & 428 & $<6$ & $<1.5$ & $<15$ \\
\hline WC 84 & $\mathrm{md}$ & $6 / 29 / 98$ & $<5$ & 12.4 & $<1.5$ & $<5$ & 392 & $<6$ & $<1.5$ & $<15$ \\
\hline WC 87 & $\mathrm{md}$ & $6 / 03 / 98$ & $<10$ & 11.1 & 21.9 & 12.2 & 184 & $<6$ & $<1.5$ & $<12$ \\
\hline WC 91 & md & $6 / 22 / 98$ & 5.5 & 6.8 & $<1.5$ & 6.2 & 794 & $<6$ & $<1.5$ & $<15$ \\
\hline WC 98 & md & $5 / 29 / 98$ & $<10$ & 11.4 & 21.3 & 23.1 & 35.3 & $<6$ & $<1.5$ & $<12$ \\
\hline WB 402 & $\mathrm{md}$ & $7 / 01 / 98$ & 80.8 & 127 & 2.4 & $<5$ & 68.8 & $<6$ & $<1.5$ & 96.6 \\
\hline WB 404 & $\mathrm{md}$ & $6 / 01 / 98$ & $<10$ & 9.7 & 50.6 & $<5$ & 1,010 & $<6$ & $<1.5$ & $<12$ \\
\hline WC 81 & $\mathrm{mi}$ & $6 / 16 / 98$ & $<5$ & 10.7 & $<1.5$ & 10.5 & 471 & $<6$ & $<1.5$ & $<15$ \\
\hline WC 85 & $\mathrm{mi}$ & $6 / 29 / 98$ & $<5$ & 21.4 & $<1.5$ & $<5$ & 256 & $<6$ & $<1.5$ & 15.5 \\
\hline WC 88 & $\mathrm{mi}$ & $6 / 03 / 98$ & $<10$ & 7 & 19 & 10.5 & 18 & $<6$ & $<1.5$ & $<12$ \\
\hline WC 92 & $\mathrm{mi}$ & $6 / 22 / 98$ & 7 & 13.7 & $<1.5$ & 61.2 & 81.9 & $<6$ & $<1.5$ & $<15$ \\
\hline WB 405 & $\mathrm{mi}$ & $6 / 01 / 98$ & 12.9 & 6.1 & 6.8 & 6.2 & 247 & $<6$ & $<1.5$ & 15.9 \\
\hline WC 82 & $\mathrm{~ms}$ & $6 / 16 / 98$ & 15.6 & 19.6 & $<1.5$ & 13.6 & 98.3 & $<6$ & $<1.5$ & $<15$ \\
\hline WC 86 & $\mathrm{~ms}$ & $6 / 29 / 98$ & $<5$ & 50.3 & $<1.5$ & 2,560 & 107 & 7.3 & $<1.5$ & $<15$ \\
\hline WC 89 & $\mathrm{~ms}$ & $6 / 03 / 98$ & $<10$ & 14.1 & 20.8 & 15.3 & 192 & $<6$ & $<1.5$ & $<12$ \\
\hline WC 93 & $\mathrm{~ms}$ & $6 / 22 / 98$ & 8.1 & 34.4 & $<1.5$ & 1,300 & 153 & $<6$ & $<1.5$ & $<15$ \\
\hline WC 95 & $\mathrm{~ms}$ & $6 / 18 / 98$ & 38.1 & 18.2 & $<10$ & 295 & 979 & 11.8 & $<1.5$ & 4.3 \\
\hline WC 97 & $\mathrm{~ms}$ & $5 / 29 / 98$ & $<10$ & 9.2 & 5.6 & 22.4 & 729 & $<6$ & $<1.5$ & $<12$ \\
\hline WC 110 & $\mathrm{~ms}$ & $7 / 07 / 98$ & $<5$ & 1.8 & $<1.5$ & $<5$ & 5.1 & $<6$ & $<1.5$ & $<1.5$ \\
\hline WB 401 & $\mathrm{~ms}$ & $7 / 01 / 98$ & $<5$ & 2.2 & $<1.5$ & $<5$ & 55.4 & $<6$ & $<1.5$ & $<1.5$ \\
\hline WB 406 & $\mathrm{~ms}$ & $6 / 01 / 98$ & $<10$ & 2.3 & 31 & 11.4 & 92.5 & $<6$ & $<1.5$ & $<12$ \\
\hline
\end{tabular}




\section{Surface Water}

Water samples were collected during low flow on July 27 and 28, 1998 from six locations on three streams draining the Nutmeg Valley study area to determine the surface-water quality when streamflow is derived primarily from ground-water discharge. Measurements of stream discharge were made concurrently so that instantaneous constituent loads could be determined. One sample was collected from station 01208283 on the unnamed tributary to Old Tannery Brook during a high-flow event on July 1, 1998 in response to 3.8 in. of precipitation (as measured at Burlington, Conn.) to determine if surface runoff from the North End Disposal Area contributed to water-quality conditions in the study area. Surface-water sampling locations are shown in plate 1 and on figure 24 .

\section{Volatile Organic Compounds}

VOCs were detected only in the downstream reaches of two rivers draining the study area (table 11). TCE, vinyl chloride, and $c 1,2-\mathrm{DCE}$ were detected in samples collected from the downstream end of Old Tannery Brook (station 01208288), and TCE and $c$ 1,2DCE were detected in samples from the Mad River at Sharon Rd. (station 01208290). The results of the sampling show that VOCs were not present above the $1-\mu \mathrm{g} / \mathrm{L}$ reporting limit in areas upstream from the study area. These data compare well with the results of the vapor-diffusion sampling, which showed several areas mostly along Old Tannery Brook and the Mad River where VOCs were discharging to surface water. Vinyl chloride was detected at the USEPA MCL of $2 \mu \mathrm{g} / \mathrm{L}$ in Old Tannery Brook; all other VOC detections were below USEPA MCLs.

Instantaneous loads of VOCs were determined by multiplying the instantaneous discharge by the VOC concentration. Results have been converted to grams per day (table 11). The mass of VOCs discharging from Old Tannery Brook on July 27, 1998 (assuming the flow and concentration were stable on that day) was about $29 \mathrm{~g}$, of which $10 \mathrm{~g}$ were TCE. The load of VOCs in the Mad River at Sharon Rd. on July 28, 1998 was equivalent to about $63 \mathrm{~g} / \mathrm{d}$, of which $42 \mathrm{~g}$ were TCE. It is not certain whether or not the loads of VOCs calculated are representative of the average concentrations in the streams because width-integrated samples were not collected, and it is likely that water discharging to the Mad River from Old Tannery Brook is not well mixed with the Mad River by the time it reaches Sharon $\mathrm{Rd}$. Also it is likely that some loss of VOCs to the atmosphere by volatilization would be expected. The calculations have been made to help understand the mass of VOCs leaving the study area through streams.

Table 11. Concentrations and instantaneous loads of volatile organic compounds detected in surface-water samples from the Nutmeg Valley study area, Wolcott and Waterbury, Connecticut, July 1998

$\left[\mathrm{ft}^{3} / \mathrm{s}\right.$, cubic ft per second; TCE, trichloroethene; $\mu \mathrm{g} / \mathrm{L}$, micrograms per liter; $\mathrm{g} / \mathrm{d}$, grams per day; $c$ 1,2-DCE, cis 1,2-dichloroethene; <less than; —, not applicable; *, stormflow sample (all other samples during low flow)]

\begin{tabular}{|c|c|c|c|c|c|c|c|c|c|}
\hline $\begin{array}{c}\text { Station } \\
\text { number } \\
\text { (location } \\
\text { shown on } \\
\text { pl. 1) }\end{array}$ & $\begin{array}{c}\text { Date } \\
\text { sampled }\end{array}$ & $\begin{array}{c}\text { Drainage } \\
\text { area in } \\
\text { square } \\
\text { miles }\end{array}$ & $\begin{array}{c}\text { Dis- } \\
\text { charge } \\
\text { in } \mathrm{ft}^{3} / \mathrm{s}\end{array}$ & $\begin{array}{c}\text { TCE in } \\
\mu \mathrm{g} / \mathrm{L}\end{array}$ & $\begin{array}{l}\text { Instanta- } \\
\text { neous } \\
\text { load in } \mathrm{g} / \mathrm{d}\end{array}$ & $\begin{array}{l}\text { Vinyl } \\
\text { chlo- } \\
\text { ride in } \\
\mu \mathrm{g} / \mathrm{L}\end{array}$ & $\begin{array}{c}\text { Instanta- } \\
\text { neous } \\
\text { load in } \\
\text { g/d }\end{array}$ & $\begin{array}{c}c 1,2- \\
D C E \\
\text { in } \mu \mathrm{g} / \mathrm{L}\end{array}$ & $\begin{array}{l}\text { Instanta- } \\
\text { neous } \\
\text { load in } \mathrm{g} / \mathrm{d}\end{array}$ \\
\hline \multicolumn{10}{|c|}{ Unnamed tributary to Old Tannery Brook sites } \\
\hline $01208283^{*}$ & $7 / 01 / 98$ & 0.23 & 1.70 & $<1$ & - & $<1$ & - & $<1$ & - \\
\hline \multicolumn{10}{|c|}{ Old Tannery Brook sites } \\
\hline 01208280 & $7 / 27 / 98$ & 2.74 & 0.75 & $<1$ & - & $<1$ & - & $<1$ & - \\
\hline 01208288 & $7 / 27 / 98$ & 3.71 & .98 & 4 & 10 & 2 & 5 & 6 & 14 \\
\hline \multicolumn{10}{|c|}{ Mad River sites } \\
\hline
\end{tabular}




\section{Inorganic constituents}

Samples were collected from the six surfacewater sites and analyzed for inorganic constituents including field measurements, major ions, cyanide, and dissolved and total trace elements (tables 12 to 14). No samples contained concentrations of inorganic constituents higher than any USEPA MCLs, and cyanide was not detected in any samples. The results show a general increase in concentration of dissolved ions from upstream to downstream on the three streams sampled during low-flow conditions (July 27-28, 1998). The largest increases in concentration were between stations 01208283 and 01208286 on the unnamed tributary to Old Tannery Brook. The increases are presumably due to solute inputs from industrialized parts of the Nutmeg Valley study area. The headwaters of this stream include part of the North End Disposal Area. Elevated concentrations of bromide (with respect to other surface-water samples) were detected in high and low-flow surface-water samples collected from the unnamed tributary. Ground-water samples collected from near the North End Disposal Area also contained elevated concentrations of bromide, therefore, surface water samples from the unnamed tributary to Old Tannery Brook may contain some water that is derived from ground-water discharge or overland runoff from the vicinity of the North End Disposal area. Samples from the unnamed tributary also contained higher concentrations of aluminum, copper, and zinc than any of the other surface-water samples collected.

Table 12. Values of field measurements in surface-water samples collected in the Nutmeg Valley study area, Wolcott and Waterbury, Connecticut, July 1998

$\left[\mathrm{mi}^{2}\right.$, square miles; $\mathrm{ft}^{3} / \mathrm{s}$, cubic $\mathrm{ft}$ per second; ${ }^{\circ} \mathrm{C}$, degrees Celsius; $\mu \mathrm{S} / \mathrm{cm}$, microsiemens per centimeter; $\mathrm{mg} / \mathrm{L}$, milligrams per liter; $\mathrm{HCO}_{3}$, bicarbonate ion; $\mathrm{CaCO}_{3}$, calcium carbonate; ${ }^{*}$, stormflow sample (all other samples during low flow)]

\begin{tabular}{|c|c|c|c|c|c|c|c|c|c|}
\hline $\begin{array}{l}\text { Station number } \\
\text { (location shown } \\
\text { on pl. 1) }\end{array}$ & $\begin{array}{c}\text { Date } \\
\text { sampled }\end{array}$ & $\begin{array}{c}\text { Drainage } \\
\text { area } \\
\left(\mathrm{mi}^{2}\right)\end{array}$ & $\begin{array}{c}\text { Dis- } \\
\text { charge } \\
\left(\mathrm{ft}^{3} / \mathrm{s}\right)\end{array}$ & $\begin{array}{c}\text { Temper- } \\
\text { ature } \\
\left({ }^{\circ} \mathrm{C}\right)\end{array}$ & $\begin{array}{c}\mathrm{pH} \\
\text { (stan- } \\
\text { dard } \\
\text { units) }\end{array}$ & $\begin{array}{c}\text { Specific } \\
\text { conduc- } \\
\text { tance } \\
(\mu \mathrm{S} / \mathrm{cm} \\
\left.\text { at } 25^{\circ} \mathrm{C}\right)\end{array}$ & $\begin{array}{l}\text { Dis- } \\
\text { solved } \\
\text { oxygen } \\
(\mathrm{mg} / \mathrm{L})\end{array}$ & $\begin{array}{c}\mathrm{HCO}_{3} \\
(\mathrm{mg} / \mathrm{L})\end{array}$ & $\begin{array}{l}\text { Alkalin- } \\
\text { ity as } \\
\mathrm{CaCO}_{3} \\
\text { (mg/L) }\end{array}$ \\
\hline \multicolumn{10}{|c|}{ Unnamed tributary to Old Tannery Brook sites } \\
\hline $01208283^{*}$ & $7 / 1 / 98$ & 0.23 & 1.70 & 17.6 & 7.3 & 212 & 9.6 & 38 & 31 \\
\hline 01208283 & $7 / 27 / 98$ & .23 & .02 & 16.8 & 5.9 & 110 & 3.8 & 18 & 15 \\
\hline 01208286 & $7 / 27 / 98$ & .64 & .03 & 19.7 & 6.9 & 258 & 7.2 & 45 & 37 \\
\hline \multicolumn{10}{|c|}{ Old Tannery Brook sites } \\
\hline 01208280 & $7 / 27 / 98$ & 2.7 & .75 & 22.9 & 7.1 & 136 & 8.5 & 19 & 16 \\
\hline 01208288 & $7 / 27 / 98$ & 3.71 & .98 & 20.8 & 6.8 & 154 & 7.9 & 20 & 17 \\
\hline \multicolumn{10}{|l|}{ Mad River sites } \\
\hline 01208270 & $7 / 28 / 98$ & 12.4 & 7.45 & 22.1 & 7.1 & 133 & 8.8 & 16 & 13 \\
\hline 01208290 & $7 / 28 / 98$ & 16.0 & 8.58 & 21.9 & 6.9 & 144 & 7.6 & 18 & 15 \\
\hline
\end{tabular}


Table 13. Concentrations of dissolved anions, cations, and cyanide in surface-water samples collected in the Nutmeg Valley study area, Wolcott and Waterbury, Connecticut, July 1998

[All concentrations in milligrams per liter. ND, not detected; <, less than specified reporting limit; ${ }^{*}$, stormflow sample (all other samples during low flow)]

\begin{tabular}{|c|c|c|c|c|c|c|c|c|c|c|}
\hline $\begin{array}{c}\text { Station } \\
\text { number } \\
\text { (location } \\
\text { shown on } \\
\text { pl. 1) }\end{array}$ & $\begin{array}{c}\text { Date } \\
\text { sampled }\end{array}$ & Fluoride & Chloride & Bromide & $\begin{array}{l}\text { Phos- } \\
\text { phate }\end{array}$ & Sulfate & Nitrate & Calcium & $\begin{array}{l}\text { Magne- } \\
\text { sium }\end{array}$ & Cyanide \\
\hline \multicolumn{11}{|c|}{ Unnamed tributary to Old Tannery Brook sites } \\
\hline $01208283 *$ & $7 / 01 / 98$ & ND & 24.2 & 0.19 & ND & 27.5 & 0.74 & 13.4 & 4.8 & $<0.08$ \\
\hline 01208283 & $7 / 27 / 98$ & ND & 19.7 & .17 & ND & 9.1 & .35 & 4.8 & 2 & $<0.04$ \\
\hline 01208286 & $7 / 27 / 98$ & ND & 39.5 & .15 & ND & 21.2 & 1.13 & 17.5 & 4.6 & $<0.04$ \\
\hline \multicolumn{11}{|c|}{ Old Tannery Brook sites } \\
\hline 01208280 & $7 / 27 / 98$ & ND & 24.2 & ND & ND & 9.2 & .68 & 7.3 & 1.9 & $<0.04$ \\
\hline 01208288 & $7 / 27 / 98$ & ND & 27.6 & ND & ND & 9.4 & 1.03 & 8.1 & 2.1 & $<0.04$ \\
\hline \multicolumn{11}{|c|}{ Mad River sites } \\
\hline 01208270 & $7 / 28 / 98$ & ND & 27.3 & ND & ND & 7.3 & 1.3 & 6.6 & 1.8 & $<0.04$ \\
\hline 01208290 & $7 / 28 / 98$ & ND & 28.9 & ND & ND & 7.8 & 1.61 & 7.5 & 2 & $<0.04$ \\
\hline
\end{tabular}

Table 14. Concentrations of trace elements detected in surface-water samples collected in the Nutmeg Valley study area, Wolcott and Waterbury, Connecticut, July 1998

[All concentrations in micrograms per liter. <, less than; D, dissolved (filtered through a 0.45 -micron filter); $T$, total (unfiltered); *, stormflow sample (all other samples during low flow)]

\begin{tabular}{|c|c|c|c|c|c|c|c|c|}
\hline $\begin{array}{l}\text { Station number } \\
\text { (location shown } \\
\text { on pl. 1) }\end{array}$ & $\begin{array}{c}\text { Sample } \\
\text { type }\end{array}$ & Date sampled & Aluminum & Barium & Copper & Iron & Manganese & Zinc \\
\hline \multicolumn{9}{|c|}{ Unnamed tributary to Old Tannery Brook sites } \\
\hline \multirow[b]{2}{*}{$01208283^{*}$} & $\mathrm{D}$ & $7 / 01 / 98$ & 92.1 & 17.6 & 7.8 & 288 & 13 & 23.1 \\
\hline & $\mathrm{T}$ & $7 / 01 / 98$ & 163 & 20.8 & 17.9 & 542 & 97.1 & 31.6 \\
\hline \multirow{3}{*}{01208283} & D & $7 / 27 / 98$ & 178 & 16.6 & 4.6 & 127 & 67.4 & 46.3 \\
\hline & $\mathrm{T}$ & $7 / 27 / 98$ & 230 & 17.6 & 5 & 232 & 128 & 51.6 \\
\hline & D & $7 / 27 / 98$ & 17.4 & 13.5 & 2.8 & 187 & 270 & $<30$ \\
\hline 01208286 & $\mathrm{~T}$ & $7 / 27 / 98$ & 32.7 & 14.1 & 5.4 & 628 & 291 & $<30$ \\
\hline \multicolumn{9}{|c|}{ Old Tannery Brook sites } \\
\hline \multirow{3}{*}{01208280} & D & $7 / 27 / 98$ & $<10$ & 6.9 & $<1.5$ & 162 & 20.6 & $<30$ \\
\hline & $\mathrm{T}$ & $7 / 27 / 98$ & 29.9 & 7.5 & $<1.5$ & 452 & 46.8 & $<30$ \\
\hline & $\mathrm{D}$ & $7 / 27 / 98$ & $<10$ & 9.3 & $<1.5$ & 219 & 123 & $<30$ \\
\hline 01208288 & $\mathrm{~T}$ & $7 / 27 / 98$ & 27.8 & 9.5 & $<1.5$ & 552 & 127 & $<30$ \\
\hline \multicolumn{9}{|l|}{ Mad River sites } \\
\hline \multirow{3}{*}{01208270} & D & $7 / 28 / 98$ & 11.6 & 8.9 & $<1.5$ & 289 & 111 & $<30$ \\
\hline & $\mathrm{T}$ & $7 / 28 / 98$ & 44.2 & 10.7 & $<1.5$ & 1,490 & 237 & $<30$ \\
\hline & D & $7 / 28 / 98$ & $<10$ & 9.4 & $<1.5$ & 182 & 111 & $<30$ \\
\hline 01208290 & $\mathrm{~T}$ & $7 / 28 / 98$ & 42.3 & 10.2 & $<1.5$ & 1,270 & 143 & $<30$ \\
\hline
\end{tabular}




\section{SUMMARY AND CONCLUSIONS}

Ground-water contamination was identified by Federal, State, and local government agencies during the 1980's at an industrial area on the Wolcott/Waterbury, Connecticut town line. Previous studies of the Nutmeg Valley Superfund Site have shown that the most commonly detected volatile organic compounds (VOCs) in supply wells were TCE, PCE, and TCA. Concentrations of VOCs in some wells have been decreasing since 1985. The highest concentrations of VOCs (primarily TCE and its transformation products) in soil and ground water in the study area were detected during a study of a former waste-disposal lagoon by a private consulting firm. Free-phase TCE was present in some samples at depth in the surficial aquifer at this location.

The USGS has conducted two phases of investigation on the hydrogeology and water quality of the Nutmeg Valley Superfund site and adjacent areas. The report from the first phase included information on the physiographic, geologic, and hydrologic framework, water use, history of ground-water and soil contamination, and presented a preliminary conceptual model of ground-water flow in the Nutmeg Valley study area.

The focus of the second phase, completed during 199799 , and described in this report, was to determine aquifer properties, aquifer geometry, ground-water-flow directions, interactions between bedrock and surficial aquifers, interactions between ground water and surface water, and general ground-water and surfacewater quality of the study area.

Surficial deposits in the study area consist of glacial till, glacial stratified deposits, and postglacial floodplain deposits. The thinnest surficial deposits are in the upland areas surrounding the study area, and the thickest surficial deposits (greater than $85 \mathrm{ft}$ ) are in two areas - one near the confluence of Old Tannery Brook with the Mad River, and the other on a terrace near the western edge of the Tosun $\mathrm{Rd}$. residential area. The horizontal hydraulic conductivity of coarse-grained glacial stratified deposits ranged from 2.3 to $21 \mathrm{ft} / \mathrm{d}$. The horizontal hydraulic conductivity of fine-grained lacustrine deposits and till determined from two slug tests are $0.8 \mathrm{ft} / \mathrm{d}$ and $2.7 \mathrm{ft} / \mathrm{d}$, respectively.

Bedrock in the study area consists of well-foliated gneiss, granofels, and local pegmatite sills. Wellfoliated gneiss is the predominant rock type penetrated by seven bedrock wells in which borehole logs were collected. In most of the wells, the strike of foliation is consistently oriented north with an easterly dip of approximately $50^{\circ}$ to $60^{\circ}$.

Water in the bedrock aquifer flows exclusively through systems of interconnected fractures, which may be divided into three types-horizontal to subhorizontal (low-angle) fractures that are "unroofing" joints parallel to the bedrock surface, high-angle fractures, and layer- or foliation-parallel fractures. Low-angle fractures measured in bedrock wells had varying orientations, whereas high-angle fractures strike north and predominantly dip east. Heat-pulse flowmeter logs indicate that a large percentage of the water in some wells comes from shallow, low-angle fractures at or near the top of the bedrock surface. Ground-water recharge (natural and induced by pumping), discharge to and from the surficial aquifer, and contaminant transport may take place through high-angle fractures. Short-circuit pathways between fracture zones are present and may have facilitated vertical and lateral spreading of VOCs in the bedrock aquifer.

Ground-water-flow directions in the surficial aquifer are generally toward discharge points along streams. Water from shallow depths discharges to Old Tannery Brook from the west, north, and east. Water in deeper parts of the surficial aquifer likely flows under Old Tannery Brook and discharges to the Mad River in the southern part of the study area. The Mad River is the discharge area for the larger scale flow system, which includes the intermediate depths in the surficial aquifer and the underlying bedrock aquifer. Generalized ground-water-flow direction in the bedrock aquifer is primarily southeast toward the Mad River, except in the Tosun Rd. residential area, where the general flow direction is southwest. Fracture orientation may control local ground-water-flow directions in the bedrock.

Water-level measurements made in September 1998 indicate that some northern sections of the study area are recharge areas and have downward vertical hydraulic gradients-from the surficial aquifer to the bedrock aquifer. The southern, downgradient sections of the study area have upward vertical hydraulic gradients-from the bedrock to the surficial aquifer. In the past, contaminants could have moved downward, from the surficial to the bedrock aquifer, or upward, from the bedrock to the surficial aquifer, depending on location in the ground-water-flow system. Vertical hydraulic gradients also were present in the surficial aquifer. An analysis of long-term water-level measurements shows that vertical gradients in the surficial aquifer are tempo- 
rally variable and may change in magnitude and direction in response to variations in ground-water recharge. This is one possible mechanism to spread contamination vertically.

Water levels in wells rose quickly in response to recharge (April to June 1998) and generally declined during most of the summer because of ground-water discharge and evapotranspiration. The analysis of data from pressure transducers installed in four wells showed that ground-water withdrawals are currently affecting ground-water levels at three or more locations in the study area. Pumping from wells completed in the bedrock aquifer can affect water levels in wells in both the bedrock and surficial aquifers to a distance of at least $200 \mathrm{ft}$ from the pumped well, causing normally upward gradients from the bedrock to the surficial aquifers to reverse. This illustrates how contamination can spread from the surficial aquifer to supply wells. Patterns of water-level fluctuation in the Tosun Rd. residential subdivision show that some fracture pathways likely connect domestic-supply wells. Pumping from a well completed in the surficial aquifer on Sharon Rd. affects water levels as far as $1,000 \mathrm{ft}$ from the pumped well. This pumping, along with other unknown nearby pumping in the Sharon Rd. area, may be inducing flow upward from the bedrock aquifer and could possibly affect flow patterns in the surficial aquifer.

During low flow, when discharge of the Mad River at Sharon Rd. is $10 \mathrm{ft}^{3} / \mathrm{s}$ (cubic feet per second) or less, and all flow in the streams is likely derived from ground-water discharge, streamflow gains ranged from 0.3 to $1.4 \mathrm{ft}^{3} / \mathrm{s}$ in the Mad River between upstream and downstream measurement points. The gain in streamflow in the study area is equivalent to a ground-water discharge of 0.19 to $0.93 \mathrm{Mgal} / \mathrm{d}$ (million gallons per day) ( 0.05 to $\left.0.25 \mathrm{Mgal} / \mathrm{d} / \mathrm{mi}^{2}\right)$, and is only slightly larger than estimated ground-water withdrawals from the study area. Low-flow measurements made in July 1998 , in conjunction with surface-water quality sampling, indicated only a small amount of ground water $\left(0.15 \mathrm{ft}^{3} / \mathrm{s}\right)$ discharged directly to the Mad River from the study area and that the part of Old Tannery Brook in the study area contributed about 20 percent of the streamflow gain between the upstream and downstream Mad River stations.

Vertical gradients were generally upward between ground water and streams at locations along Old Tannery Brook and the Mad River. The lower 600 $\mathrm{ft}$ of the unnamed tributary to Old Tannery Brook had a downward vertical gradient from the stream to the ground water, indicating that surface water recharges the surficial aquifer at this location. This could provide a pathway for contaminant migration if the water in the unnamed tributary contained contaminants.

Concentrations of TCE measured in vapor-diffusion samplers in July and November 1997 ranged from less than the detection limit to greater than 30,000 parts per billion by volume. The highest concentrations were in zones along the lower reach of Old Tannery Brook and along the Mad River near the southern boundary of the Superfund Site. The compounds PCE, $c$ 1,2-DCE, and benzene also were detected at some locations. The area of detections along the lower reach of Old Tannery Brook may be related to the presence of a known ground-water contamination plume near the stream that contains TCE. The area with the second highest concentration of TCE in vapor-diffusion samples was along the Mad River just north of Sharon Rd.; this high concentration may be related to the discharge of ground water to the Mad River from beneath a semi-confining layer of fine-grained deposits. VOCs were detected in vapor-diffusion samples at several other locations, including areas along the unnamed tributary southeast of Swiss Lane and Venus Drive and locations along the Mad River upstream from Old Tannery Brook.

Ground-water samples were collected from below the streambed of Old Tannery Brook at two locations with the highest vapor concentrations of TCE. These water samples contained TCE concentrations ranging from 30 to $2,900 \mu \mathrm{g} / \mathrm{L}$ (micrograms per liter), $c$ 1,2-DCE concentrations ranging from less than 1 to $1,200 \mu \mathrm{g} / \mathrm{L}$, and 1,1-DCA concentrations ranging from less than 1 to $2,100 \mu \mathrm{g} / \mathrm{L}$.

Fourteen of 44 ground-water samples collected from May to September 1998 contained detectable concentrations of VOCs; however, samples from only three wells contained concentrations of VOCs above USEPA Maximum Contaminant Levels. The sampling indicated that some locations and depths in the surficial and bedrock aquifers are free from contamination by VOCs. Based on the 1998 sampling, previously existing data, and the general direction of ground-water flow, it is likely that VOCs (primarily TCE, PCE, and TCA) are present in the bedrock aquifer in the southern part of the site, specifically south of the unnamed tributary to Old Tannery Brook, south of Town Line Rd., and west of the Mad River. No VOCs were present in any of the six wells sampled in the Tosun Rd. residential area or in samples from two businesses located adjacent to the residential subdivision. However, some 
samples collected in the residential area by the Chesprocott Health District during 1998 contained MTBE. No VOCs were detected above MCLs in any of the samples collected by the Chesprocott Health District, but other VOCs including chloroform, toluene, PCE, TCE, TCA, and methylene chloride were detected at low concentrations in samples from some wells.

With the exception of one monitoring-well sample, concentrations of major ions or trace elements in ground water did not exceed any USEPA MCLs. Concentrations of inorganic constituents in some wells were higher than ambient levels, indicating some degradation of ground-water quality caused by human activities. One monitoring well screened in the intermediate part of the surficial aquifer and located on Nutmeg Valley Rd. contained detectable (but below the MCL) concentrations of cyanide.

VOCs were detected in samples from the two major streams draining the study area. TCE, vinyl chloride, and $c$ 1,2-DCE were detected in samples collected from the downstream end of Old Tannery Brook, and TCE and $c$ 1,2-DCE were detected in samples from the Mad River at Sharon Rd.

No surface-water samples contained concentrations of inorganic constituents higher than any USEPA MCLs, but the sample results showed a general increase in concentration of dissolved ions from upstream to downstream on the three streams sampled during low flow on July 27 and 28, 1998. Ground-water discharge to the streams in the study area contributes to an increase in the mass of dissolved constituents leaving the site-primarily chloride, bicarbonate, sulfate, nitrate nitrogen, calcium and magnesium.
Water samples collected downgradient from the Waterbury North End Disposal Area show degradation in water quality. The VOCs ethyl ether and chlorobenzene were detected in some wells on Swiss Lane downgradient of the landfill. The low concentrations of these VOCs may be caused by migration of leachate from the landfill, because samples of leachate from the landfill and water from a monitoring well (located upgradient of Swiss Lane) contain some of the same VOCs.

Samples from wells downgradient from the North End Disposal Area also had the highest measurements of specific conductance, alkalinity, and the highest concentrations of chloride, bromide, sulfate, calcium, and magnesium. Samples of landfill leachate collected by private consultants as part of the landfillmonitoring program also had high measurements of specific conductance and alkalinity and concentrations of chloride. It is likely that water with high concentrations of dissolved solids originating at the landfill has affected water quality in the Swiss Lane area.

Samples collected from the unnamed tributary upstream from the Superfund site contained elevated bromide concentrations similar to ground-water samples collected downgradient from the North End Disposal Area. These concentrations suggest solute contributions from ground-water or surface-water runoff from the North End Disposal Area, which is located in the upstream drainage area. Stormflow from the unnamed tributary may subsequently contribute inorganic constituents to the ground-water system because a downstream reach, near the confluence with Old Tannery Brook, had downward vertical gradients, indicating flow from the stream to the surficial aquifer. 


\section{REFERENCES CITED}

Advanced Environmental Interface, Inc., 1994, Report on evaluation of ground water quality from Waterbury North End Disposal Area (NEDA) monitoring wells A,B,C,H,J; LoRusso property, Swiss Lane, Wolcott, Connecticut: Middletown, Conn., appendices A-K, $115 \mathrm{p}$.

Bouwer, Herman, and Rice, R.C., 1976, A slug test for determining hydraulic conductivity of unconfined aquifers with completely or partially penetrating wells: Water Resources Research, v. 12, no. 3, p. 423-428.

Buchanan, T.J., and Somers, W.P., 1969, Discharge measurements at gaging stations: U.S. Geological Survey Techniques of Water-Resources Investigations, book 3 chap. A8, $65 \mathrm{p}$.

Carter, R.W., and Davidian, Jacob, 1968, General procedure for gaging streams:U.S. Geological Survey Techniques of Water- Resources Investigations, book 3, chap. A6, $13 \mathrm{p}$.

Connecticut Department of Environmental Protection, 1997a, Bureau of Waste Management, Oil and Chemical Spill Response Division Referral, May 22, 1997, case number 97-01833.

1997b, Bureau of Waste Management, Oil and Chemical Spill Response Division Referral, July 8, 1997, case number 97-01833.

Cooper, H.H., Jr., Bredehoeft, J.D., and Papadopulos, I.S., 1967, Response of a finite-diameter well to an instantaneous charge of water: Water Resources Research, v. 3, no. 1, p. 263-269.

Dames and Moore, 1995, Subsurface investigation, Marson Fastener Corporation, Wolcott Connecticut: Salem, N.H., $11 \mathrm{p}$.

Edwards, T.K., and Glysson, G.D., 1988, Field methods for measurement of fluvial sediment: U.S. Geological Survey Open-File Report 86-531, $118 \mathrm{p}$.

EEW Management, Inc., 1994, Sampling of groundwater monitor wells at the Wolcott Tool Site, 143 Wolcott Road, Wolcott, Connecticut: Torrington, Conn.

1998, Subsurface investigation, National Die Company, Inc., 64 Wolcott Road, Wolcott, Connecticut, July 1998: Torrington, Conn.

Environmental Science \& Engineering, Inc., 1996, Highland Manufacturing/ITW, Waterbury, Connecticut, monitoring well installation: Peoria, Illinois.

Fritts, C.E., 1963, Bedrock geology of the Southington quadrangle, Connecticut: U.S. Geological Survey Map GQ200, 1 sheet, scale 1:24,000.

Fuss \& O'Neill, Inc., 1997, North End Disposal Area, quarterly operations and quarterly water quality monitoring report, Waterbury, Connecticut, August 1997.

_-1998a, Quarterly operations and water quality monitoring report, Waterbury North End Disposal Area Waterbury, Connecticut, January 1998. 1998b, Quarterly operations and water quality monitoring report, Waterbury North End Disposal Area Waterbury, Connecticut, May 1998.

Gates, R.M., and Martin, C.W., 1967, Bedrock geology of the Waterbury quadrangle, Connecticut: Connecticut Geological and Natural History Survey, Quadrangle Report 22, 36 p., 1 map.

Goodkind and O'dea, Inc. 1985 (draft), Engineering report of studies of contaminated wells and supply of potable water for the southerly industrial area along Route 69 in the Town of Wolcott, Connecticut, December 31, 1985, Hamden, Conn.

Grady, S.J., and Mullaney, J.R., 1998, Natural and human factors affecting shallow water quality in surficial aquifers in the Connecticut, Housatonic, and Thames River Basins: U.S. Geological Survey Water-Resources Investigations Report 98-4042, 81 p.

Hem, J.D., 1985, Study and interpretation of the chemical characteristics of natural water (3d ed.): U.S. Geological Survey Water-Supply Paper 2254, 263 p.

Heynen Engineers, 1991, Environmental site assessment, 30 Tosun Road, Wolcott, Connecticut, November 22, 1991: Guilford, Conn.

Horowitz, A.J., Demas, C.R., Fitzgerald, K.K., Miller, T.L., Ricker, D.A., 1994, USGS protocols for the collection and processing of surface-water samples for the subsequent determination of inorganic constituents in filtered water: U.S. Geological Survey Open-File Report 94$539,57 \mathrm{p}$.

HRP Associates, Inc., 1986, Site assessment report, for Celinda W. Mayo, 76 Wolcott Road, Wolcott, Connecticut: New Britain, Connecticut (updated 1988).

1991, Subsurface investigation, 14-16 Town Line Road, Wolcott, Connecticut: Plainville, Conn.

1994, Remedial investigation and feasibility study of remedial action alternatives, Highland Manufacturing, 1240 Wolcott Road, Waterbury, Connecticut: Plainville, Conn.

1995, Letter concerning Joma Inc. well water analysis report (HRP \#EJ02740.00), July 1995, Plainville, Conn.

-1996a, Groundwater monitoring fourth quarter 1995, Highland Manufacturing, 1240 Wolcott Road, Waterbury, Conn.: Plainville, Conn.

1996b, Report of additional investigations, Highland Manufacturing, 1240 Wolcott Road, Waterbury, Conn.: Plainville, Conn.

1996c, Groundwater monitoring first quarter 1996, Highland Manufacturing, 1240 Wolcott Road, Waterbury, Conn.: Plainville, Conn.

-1996d, Report of additional site investigation, 10

Venus Drive, Wolcott, Connecticut: Plainville, Conn.

1998, Environmental assessment and remedial action report, 3 Tosun Road, Wolcott, Connecticut, September, 1998: Plainville, Conn. 
Keys, W.S., 1990, Application of borehole geophysics to water-resources investigations: U.S. Geological Survey Techniques of Water-Resources Investigations, book 2, chap. E1, 126 p.

LaSala, A.M., Jr., 1961, Surficial geology of the Southington quadrangle, Connecticut: U.S. Geological Survey Geologic Quadrangle Map GQ-146, scale 1:24,000.

Lopes, T.J., and Bender, D.A., 1998, Nonpoint sources of volatile organic compounds in urban areas-relative importance of land surfaces and air: Environmental Pollution, v. 101, p. 221-230.

Loureiro Engineering Associates, 1998a, Status report, supplemental subsurface investigation, the Highland Manufacturing Company, 1240 Wolcott Road, Waterbury Connecticut, February 1998, Plainville, Conn.

1998b, Supplemental subsurface investigation report, Highland Manufacturing Company, Waterbury, Connecticut, July 1998, Plainville, Conn.

Mazzaferro, D.L., Handman, E.H., and Thomas, M.P., 1979, Water resources inventory of Connecticut, part 8, Quinnipiac River basin: Connecticut Water Resources Bulletin $27,88 \mathrm{p}$.

Melvin, R.L., 1986, Connecticut observation wells-guidelines for network modification: U.S. Geological Survey Water-Resources Investigations Report 85-4079, 24 p.

Melvin, R.L., deLima, V.A., and Stone, B.D., 1992a, Stratigraphy and hydraulic properties of tills in southern New England: U.S. Geological Survey Open-File Report 91$481,53 \mathrm{p}$.

Melvin, R.L., Stone, B.D., Stone, J.R., and Trask, N.J., 1992b, Hydrogeology of thick till deposits in Connecticut: U.S. Geological Survey Open-File Report 92-43, $43 \mathrm{p}$.

Melvin, R.L., Stone, J.R., Craft, P.A., Lane, J.W., Davies, B.S., 1995, Geohydrology and water quality of the Durham Center Area, Durham, Connecticut: U.S. Geological Survey Water-Resources Investigations Report 94-4237, 95 p., 1 appendix.

Metcalf and Eddy, 1992, Draft data summary report, Nutmeg Valley Road site, Wolcott, Connecticut: 44 p., 1 appendix.

Pankow, J.F., Cherry, J.A., 1996, Dense chlorinated solvents and other DNAPLS in ground water: Portland, Oregon, Waterloo Press, 522 p.

Radtke, D.B., and Wilde, F.D., eds., 1998, National field manual for collection of water-quality data-Field measurements: U.S. Geological Survey Techniques of Water-Resources Investigations, book 9, chap. A6, unpaginated.

Randall, A.D., Francis, R.M., Frimpter, M.H., and Emery, J.M., 1988, Region 19, Northeastern Appalachians, in Back, William, Rosenshein, J.S., and Seaber, P.R., eds., Hydrogeology: Boulder, Colorado, Geological Society of America, The Geology of North America, v. O-2, p. 177-187.
Rantz, S.E., 1982, Measurement and computation of streamflow-volume 1. Measurement of stage and discharge: U.S. Geological Survey Water-Supply Paper 2175, $284 \mathrm{p}$.

Rodgers, John (compiler), 1985, Bedrock geological map of Connecticut: Connecticut Geological and Natural History Survey, Natural Resources Atlas Series Map, 2 sheets, scale 1:125,000.

Roy F. Weston Inc., 1994, Final site inspection report, Par Finishing Inc., Wolcott, Connecticut: Wilmington, Mass., 44 p., 1 attachment.

1996, Environmental assessment of the AMP facility, 63 Wakelee Road, Wolcott, Conn.: Boston, Mass., $22 \mathrm{p}$.

Stone, J.R., Casey, G.D., Mondazzi, R.A., and Frick, T.W., 1997, Preliminary hydrogeologic assessment of a ground-water contamination area in Wolcott, Connecticut: U.S. Geological Survey Open-File Report 97-219, 29 p., 8 pl.

Stone, J.R., Schafer, J.P., London, E.H., and Thompson, W.B., 1992, Surficial materials map of Connecticut:

U.S. Geological Survey Special Map, 2 sheets, scale 1:125,000.

U.S. Environmental Protection Agency, 1989, National Priority List for uncontrolled hazardous waste sites, final update no. 5, 40 CFR, Part 300: Federal Register, v. 54, no. 61 , p. $13296-13317$.

1996, Low stress (low flow) purging and sampling procedure for the collection of ground water samples from monitoring wells, USEPA, Region 1, revision 2, $13 \mathrm{p}$.

1998, EPA Region 1 ambient air grab sample analysis for volatile organic compounds, U.S. Environmental Protection Agency, Lexington, Mass., March 1998, 6 p. Vroblesky, D.A., Rhodes, L.C., Robertson, J.F., and Harrigan, J.A., 1996, Locating VOC contamination in a fractured-rock aquifer at the ground-water/surface-water interface using passive vapor collectors: Ground Water, v. 34 , no. 2 , p. $223-230$.

Wilson, W. E., and Burke, E.L., and Thomas, C.E., Jr., 1974, Water resources inventory of Connecticut, part 5 , lower Housatonic River basin: Connecticut Water Resources Bulletin 19, 79 p.

Winter, T.C., LaBaugh, J.W., Rosenberry, D.O., 1988, Design and use of a hydraulic potentiomanometer for direct measurement of differences in hydraulic head between groundwater and surface water: Limnology and Oceanography, v. 22, no. 5, p. 1209-1214. 
APPENDIXES 
Appendix 1. Lithologic logs of wells in surficial deposits, Nutmeg Valley study area, Wolcott and Waterbury, Connecticut

\begin{tabular}{|c|c|c|c|}
\hline \multirow{2}{*}{$\begin{array}{ll}\text { WC-80 } & \text { Description of material } \\
\end{array}$} & \multicolumn{3}{|c|}{$\begin{array}{c}\text { Depth interval } \\
\text { (feet below land surface) }\end{array}$} \\
\hline & & & \\
\hline Gravel, sandy, medium to coarse, some very coarse, few granules & 0 & to & 5 \\
\hline Sand, gray. medium to coarse, some very coarse, silty, micaceous & 5 & to & 11 \\
\hline Sand, gray, fine to very fine, silty, micaceous & 11 & to & 27 \\
\hline $\begin{array}{l}\text { Sand and Gravel, reddish brown; sand, medium to very coarse; some laminations } \\
\text { of fine sand, olive }\end{array}$ & 27 & to & 69.5 \\
\hline Till & 69.5 & to & 76 \\
\hline Bedrock & 76 & & \\
\hline \multicolumn{4}{|l|}{ WC-84 } \\
\hline Artificial fill & 0 & to & 3 \\
\hline Sand, gray and brown, fine to very fine, silty, clayey & 3 & to & 29 \\
\hline $\begin{array}{l}\text { Sand and Gravel, gravel, orange brown, some } 2 \text { inch; sand, reddish brown, fine to } \\
\text { very coarse }\end{array}$ & 29 & to & 61 \\
\hline Till & 61 & to & 67 \\
\hline Bedrock & 67 & & \\
\hline \multicolumn{4}{|l|}{ WC-87 } \\
\hline Sand, fine, silty & 0 & to & 4 \\
\hline Sand, rusty orange, medium to coarse & 4 & to & 5 \\
\hline Sand and Gravel & 5 & to & 8 \\
\hline Sand, layered, fine to coarse & 8 & to & 53 \\
\hline Till & 53 & to & 63 \\
\hline Bedrock & 63 & & \\
\hline \multicolumn{4}{|l|}{ WC-91 } \\
\hline Silt, organic, black & 0 & to & 8 \\
\hline Sand, laminated, gray, very fine, silty, micaceous & 8 & to & 25 \\
\hline $\begin{array}{l}\text { Sand and Gravel; sand, fine to medium, orange brown, some coarse to very coarse; } \\
\text { gravel some } 2 \text { inch }\end{array}$ & 25 & to & 44 \\
\hline Till & 44 & to & 46.5 \\
\hline Bedrock & 46.5 & & \\
\hline \multicolumn{4}{|l|}{ WC-95 } \\
\hline Artificial fill & 0 & to & 5 \\
\hline Sand and Gravel; sand, fine to very coarse, & 5 & to & 25 \\
\hline Till & 25 & to & 31 \\
\hline Bedrock & 31 & & \\
\hline \multicolumn{4}{|l|}{ WC-97 } \\
\hline Soil, gravelly & 0 & to & 2 \\
\hline Sand and Gravel; sand, reddish brown, fine to very coarse, little granules & 2 & to & 39 \\
\hline Till; refusal at $41.5 \mathrm{ft}$ & 39 & to & 40.5 \\
\hline \multicolumn{4}{|l|}{ WB-404 } \\
\hline Soil, gravelly & 0 & to & 2.5 \\
\hline $\begin{array}{l}\text { Sand and Gravel; sand, fine to very coarse; gravel, pebbly gravel, some cobbles, up } \\
\text { to } 3 \text { inch }\end{array}$ & 2.5 & to & 29 \\
\hline Till (and or) weathered rock? refusal at $55.5 \mathrm{ft}$ & 29 & to & 55.5 \\
\hline
\end{tabular}




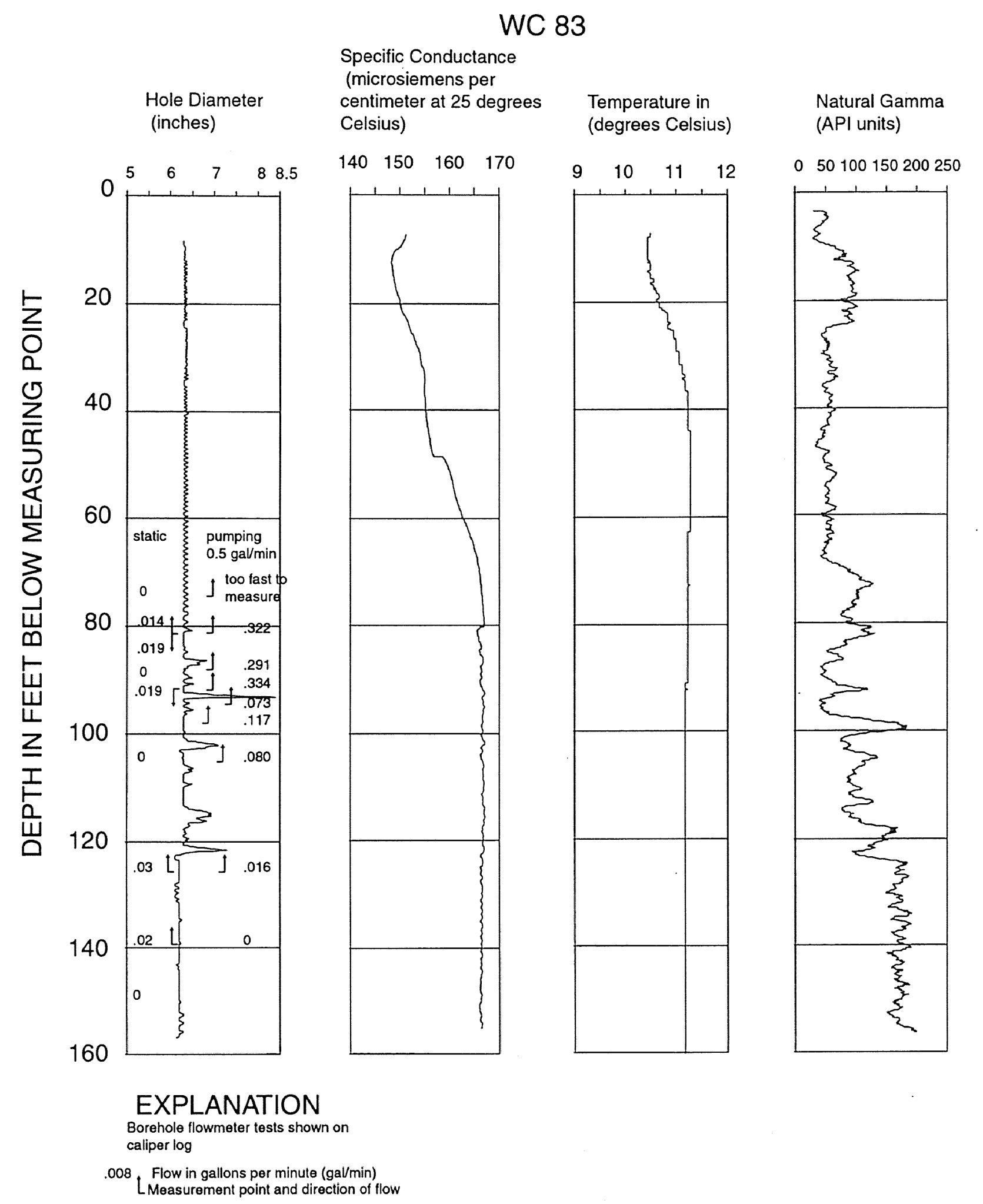


WC 90

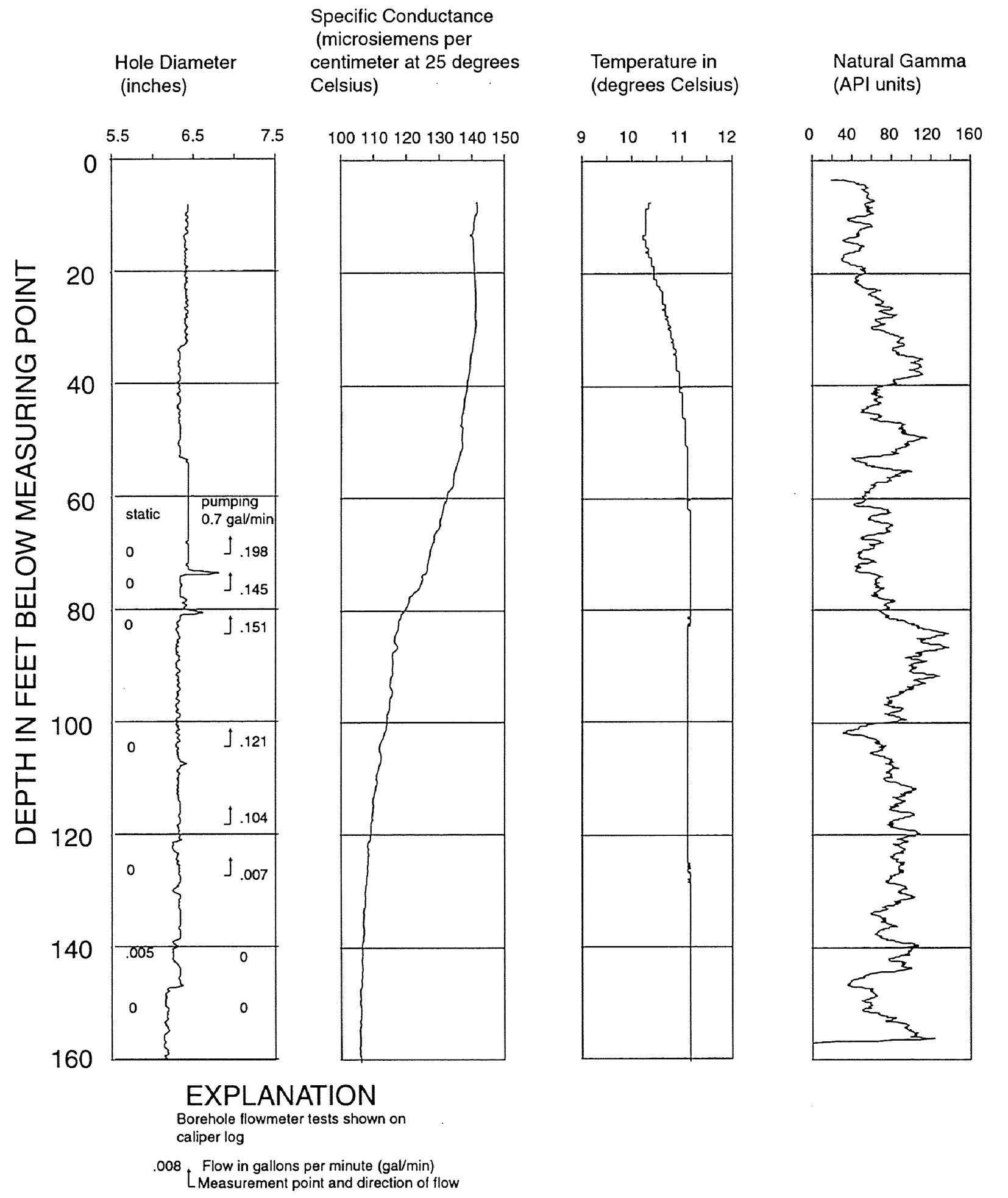




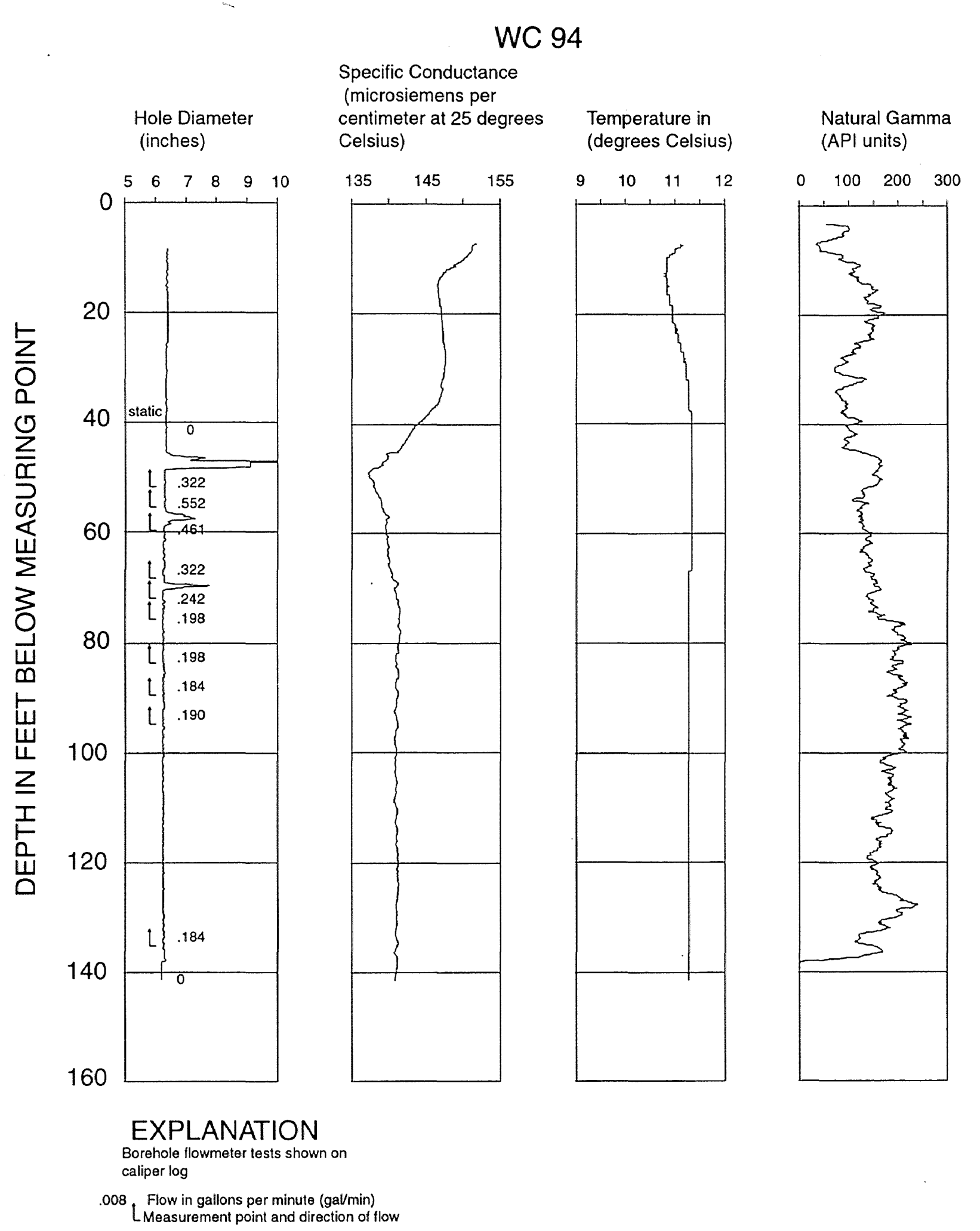




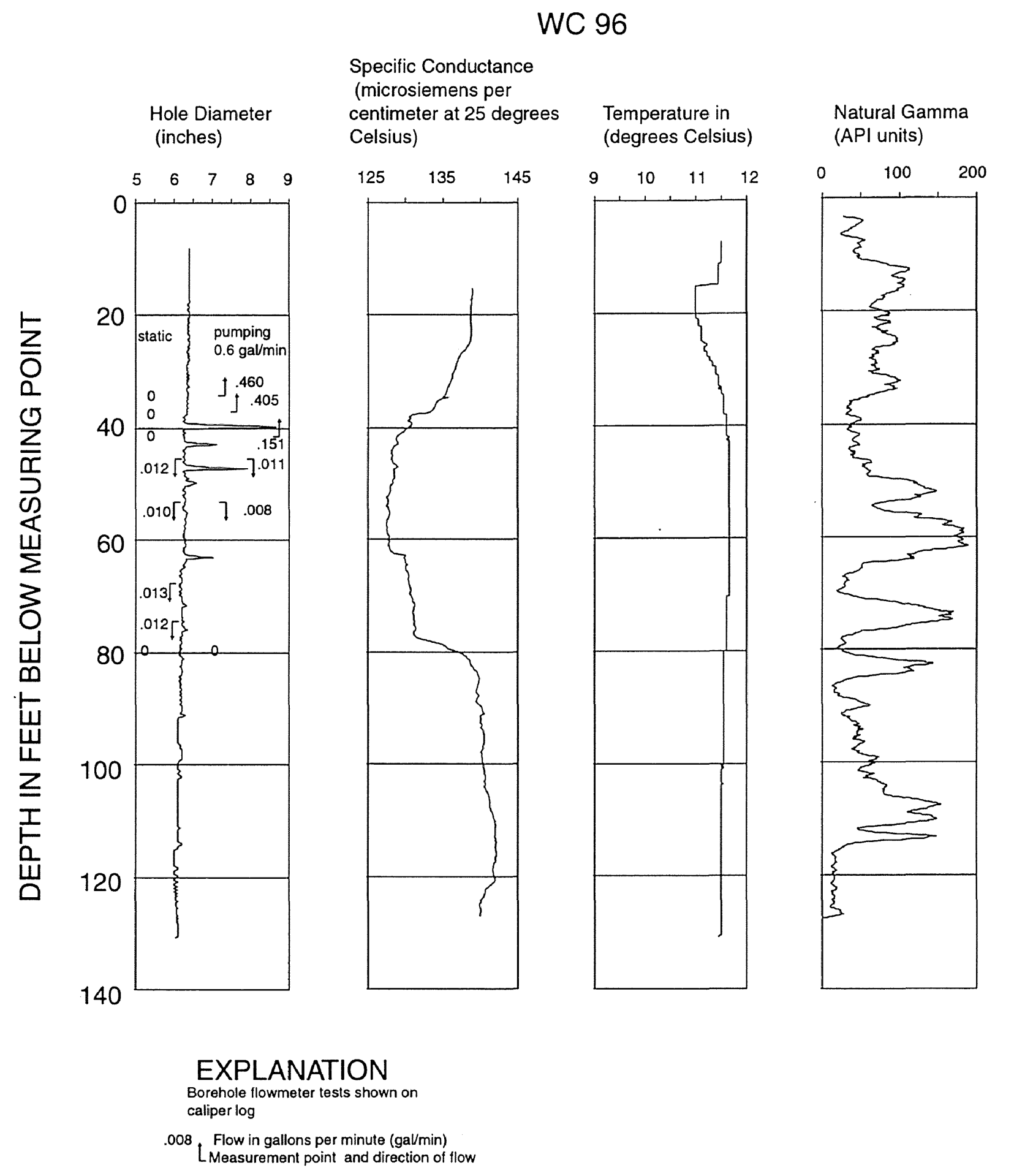




\section{WC 99}

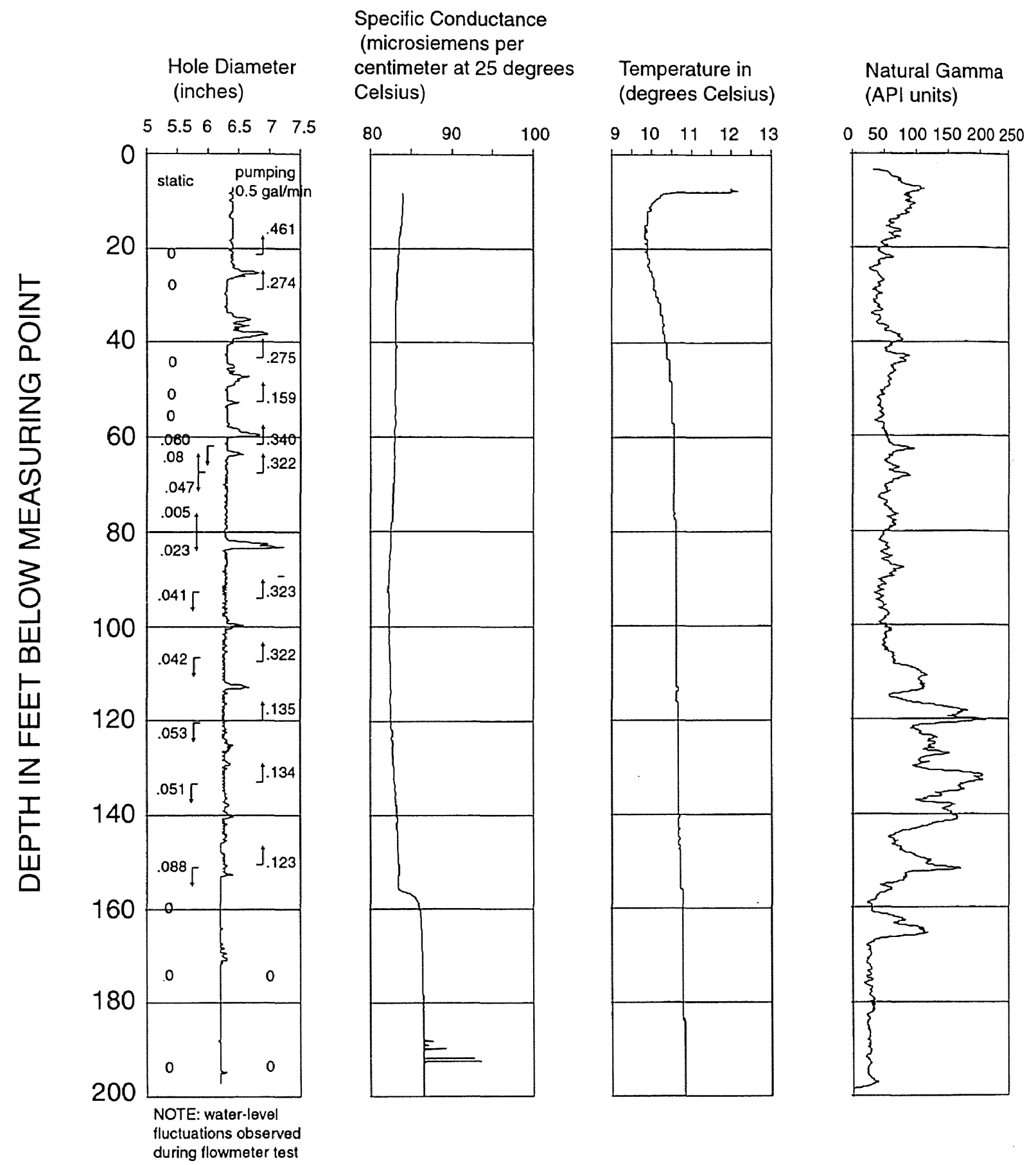

\section{EXPLANATION}

Borehole flowmeter tests shown on caliper log

.008 Flow in gallons per minute (gaV/min) 
WC 100

Hole Diameter (inches)

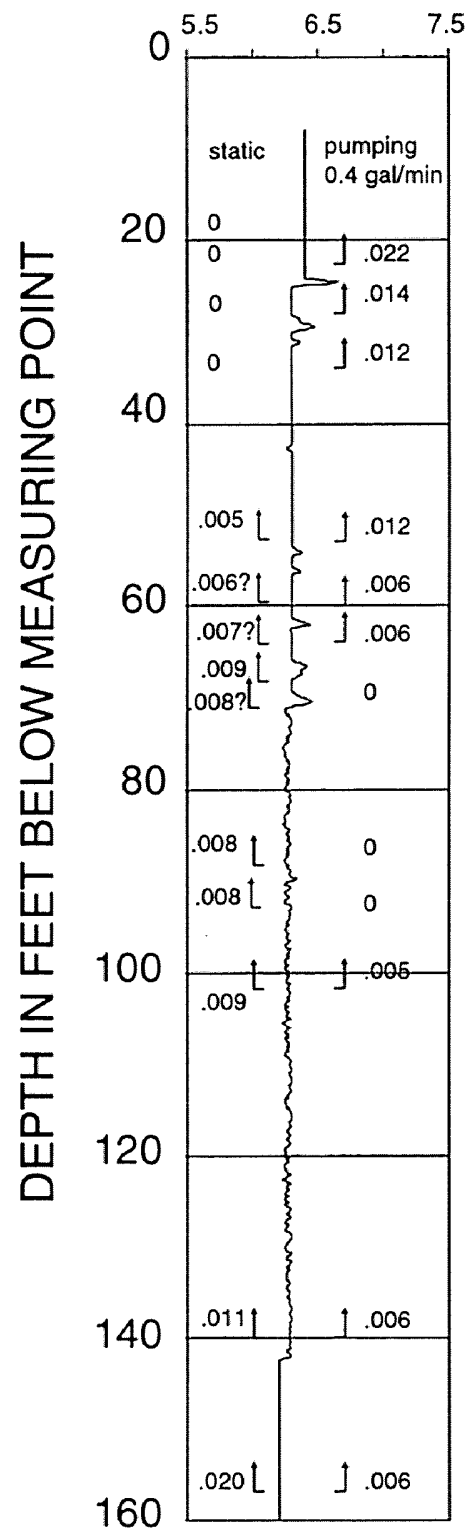

Temperature in (degrees Celsius)

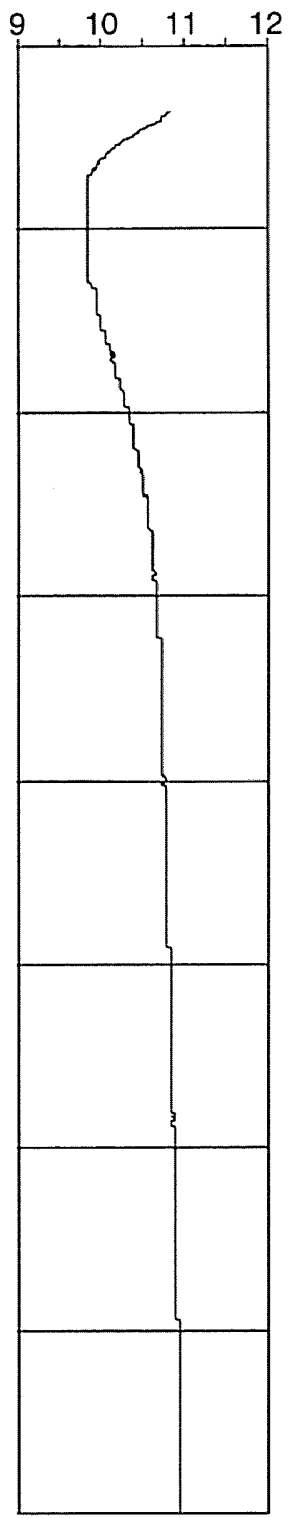

500520540560580600

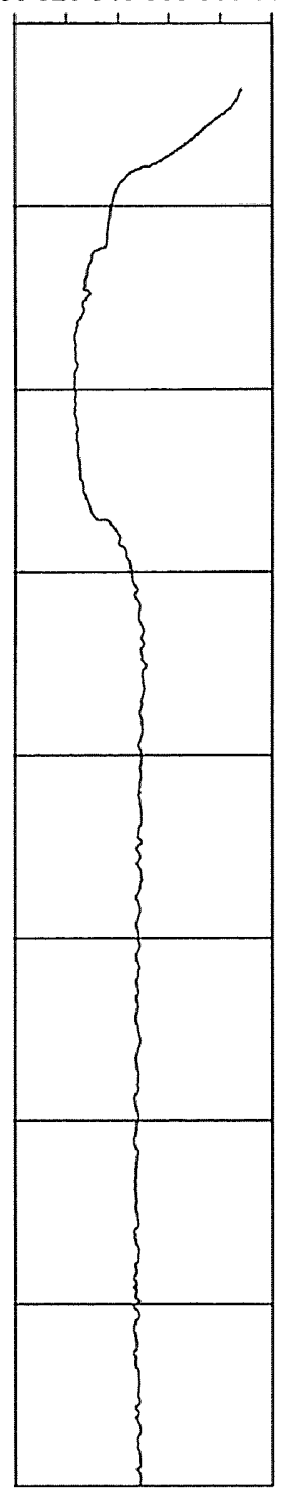

Natural Gamma (API units)

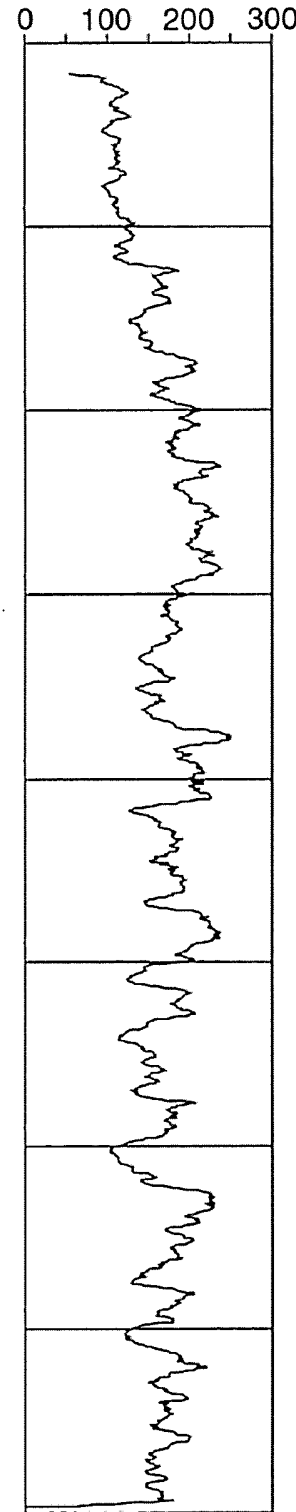

\section{EXPLANATION}

Borehole flowmeter tests shown on

caliper log

.008 Flow in gallons per minute (gal/min)

Leasurement point and direction of flow 


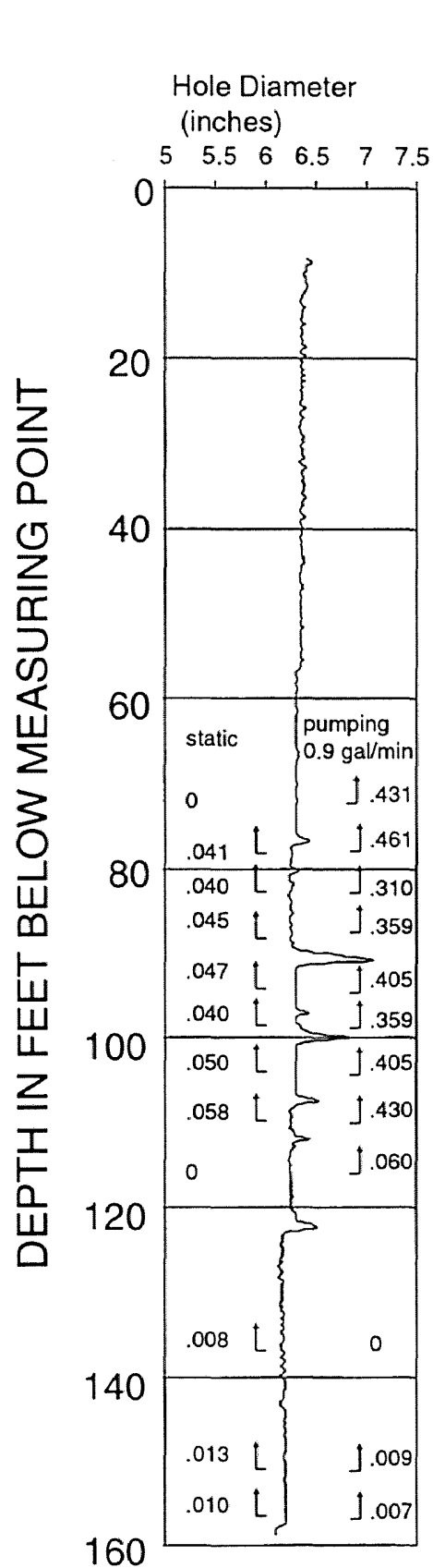

Specific Conductance (microsiemens per centimeter at 25 degrees Celsius)
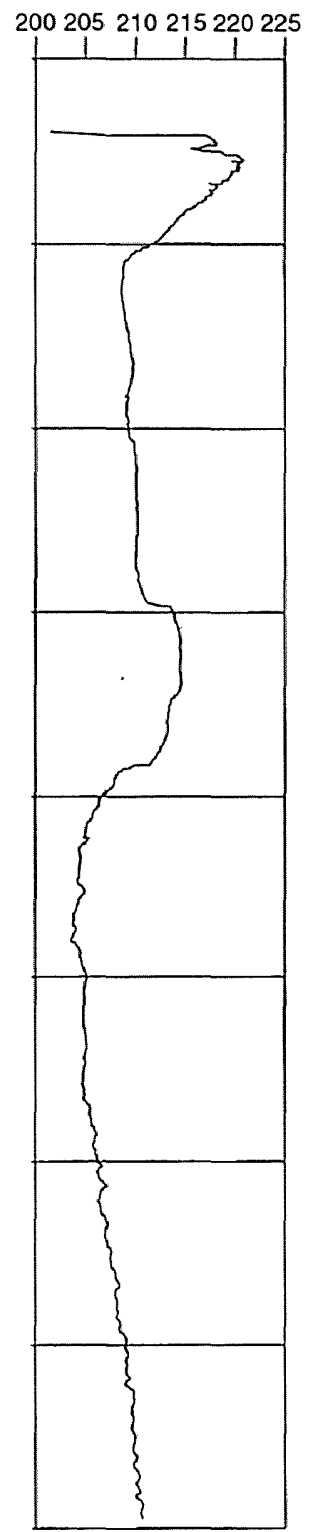

Temperature in (degrees Celsius)

Natural Gamma (API units)

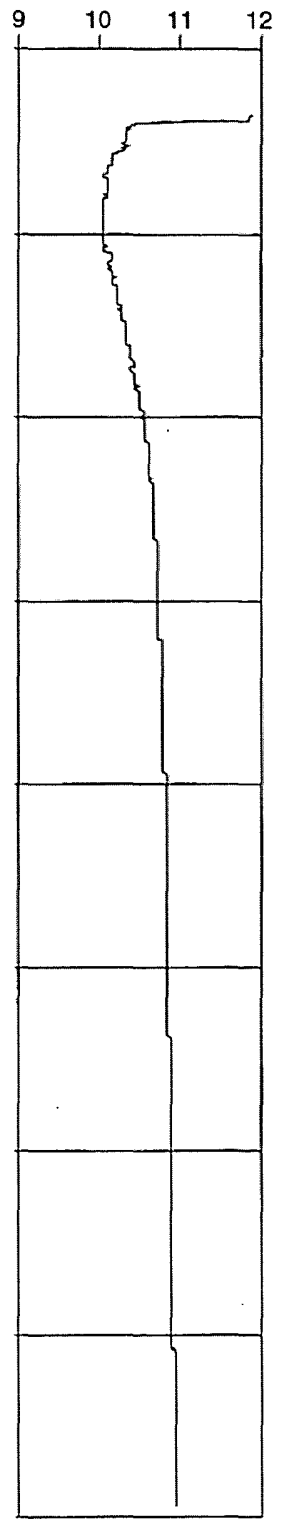

o 50100150200250

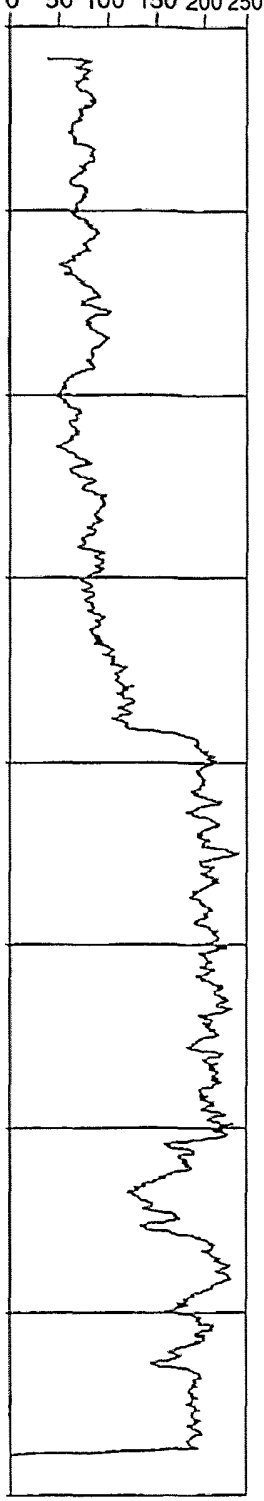

\section{EXPLANATION}

Borehole flowmeter tests shown on caliper $\log$

.008 Flow in gallons per minute (ga//min)

LMeasurement point and direction of flow 
Appendix 3. Water-level altitudes at wells/well clusters measured by the U.S. Geological Survey, 1998

[All water-level altitudes are in feet above sea level; mb, monitoring well in bedrock aquifer; md, monitoring well screened in deepest part of surficial aquifer; mi, monitoring well screened in intermediate part of surficial aquifer; ms, monitoring well screened in shallowest part of the surficial aquifer; bs, supply well at a business (unused); - , not measured]

\begin{tabular}{ccccc}
\hline \multirow{2}{*}{ Date } & \multicolumn{4}{c}{ Water-surface altitude } \\
\cline { 2 - 5 } & $\begin{array}{c}\text { WB 407 } \\
\text { mb }\end{array}$ & $\begin{array}{c}\text { WB 404 } \\
\text { md }\end{array}$ & $\begin{array}{c}\text { WB 405 } \\
\text { mi }\end{array}$ & $\begin{array}{c}\text { WB 406 } \\
\text { ms }\end{array}$ \\
\hline $04 / 23 / 98$ & - & 453.43 & 455.27 & 459.94 \\
$05 / 05 / 98$ & 461.99 & 457.41 & 457.08 & 459.99 \\
$05 / 26 / 98$ & 461.97 & - & - & - \\
$06 / 01 / 98$ & - & 459.42 & 459.47 & 459.71 \\
$06 / 02 / 98$ & 461.69 & - & - & - \\
$08 / 04 / 98$ & 460.69 & 458.31 & 458.80 & 458.61 \\
$08 / 25 / 98$ & 460.16 & - & - & - \\
$09 / 01 / 98$ & 460.25 & 457.71 & 458.41 & 458.08 \\
$09 / 10 / 98$ & 460.26 & - & - & 458.03 \\
$10 / 16 / 98$ & 461.10 & 458.93 & 459.54 & 459.20 \\
$12 / 03 / 98$ & 460.61 & 458.47 & 459.06 & 458.75 \\
\hline
\end{tabular}

\begin{tabular}{rccc}
\hline \multirow{2}{*}{ Date } & \multicolumn{3}{c}{ Water-surface altitude } \\
\cline { 2 - 4 } & $\begin{array}{c}\text { WC 84 } \\
\mathrm{md}\end{array}$ & $\begin{array}{c}\text { WC 85 } \\
\mathrm{mi}\end{array}$ & $\begin{array}{c}\text { WC } 86 \\
\mathrm{~ms}\end{array}$ \\
\hline $04 / 21 / 98$ & 459.53 & 459.58 & 460.04 \\
$04 / 23 / 98$ & 459.31 & 459.39 & - \\
$05 / 21 / 98$ & 459.31 & 459.37 & 459.46 \\
$05 / 28 / 98$ & - & 459.01 & - \\
$06 / 29 / 98$ & 458.32 & 458.34 & 459.46 \\
$08 / 27 / 98$ & 457.85 & - & 457.88 \\
$09 / 01 / 98$ & 457.64 & 457.69 & 457.65 \\
$09 / 10 / 98$ & - & 457.71 & - \\
$10 / 16 / 98$ & 458.7 & 458.76 & 459.38 \\
$12 / 03 / 98$ & 458.28 & 458.33 & 458.7 \\
\hline
\end{tabular}

\begin{tabular}{ccccc}
\hline \multirow{2}{*}{ Date } & \multicolumn{4}{c}{ Water-surface altitude } \\
\cline { 2 - 5 } & $\begin{array}{c}\text { WC 83 } \\
\mathbf{m b}\end{array}$ & $\begin{array}{c}\text { WC 80 } \\
\text { md }\end{array}$ & $\begin{array}{c}\text { WC 81 } \\
\text { ml }\end{array}$ & $\begin{array}{c}\text { WC 82 } \\
\text { ms }\end{array}$ \\
\hline $04 / 14 / 98$ & - & 457.81 & 457.65 & 452.87 \\
$05 / 20 / 98$ & 458.13 & 457.96 & 457.98 & 454.61 \\
$06 / 16 / 98$ & - & 457.57 & 457.59 & 454.5 \\
$06 / 26 / 98$ & 457.03 & - & - & - \\
$07 / 21 / 98$ & 456.88 & 456.76 & 456.77 & 453.87 \\
$08 / 04 / 98$ & 456.68 & - & - & - \\
$08 / 25 / 98$ & 456.27 & - & - & - \\
$09 / 01 / 98$ & 456.44 & 456.3 & 456.31 & 453.66 \\
$09 / 03 / 98$ & - & - & 456.25 & - \\
$09 / 08 / 98$ & 456.44 & - & - & - \\
$10 / 16 / 98$ & 457.29 & 457.14 & 457.15 & 454.35 \\
$12 / 03 / 98$ & 456.94 & 456.8 & 456.8 & 454.21 \\
\hline
\end{tabular}

\begin{tabular}{ccccc}
\hline \multirow{2}{*}{ Date } & \multicolumn{4}{c}{ Water-surface altitude } \\
\cline { 2 - 5 } & $\begin{array}{c}\text { WC 90 } \\
\text { mb }\end{array}$ & $\begin{array}{c}\text { WC 87 } \\
\text { md }\end{array}$ & $\begin{array}{c}\text { WC 88 } \\
\text { mi }\end{array}$ & $\begin{array}{c}\text { WC 89 } \\
\text { ms }\end{array}$ \\
\hline $04 / 23 / 98$ & - & 460.64 & 461.02 & 460.91 \\
$05 / 04 / 98$ & - & 460.74 & 461.15 & 461.14 \\
$05 / 20 / 98$ & 460.75 & - & - & - \\
$06 / 03 / 98$ & 460.55 & 460.71 & 461.08 & 461.03 \\
$06 / 08 / 98$ & 460.22 & - & - & - \\
$06 / 25 / 98$ & 459.83 & - & - & - \\
$08 / 27 / 98$ & - & 459.19 & 459.55 & 459.44 \\
$09 / 01 / 98$ & 458.83 & 458.9 & 459.23 & 459.12 \\
$10 / 16 / 98$ & 460 & 459.99 & 460.5 & 460.51 \\
$12 / 03 / 98$ & 459.54 & 459.58 & 460.03 & 460.01 \\
\hline
\end{tabular}




\begin{tabular}{ccccc}
\hline \multirow{2}{*}{ Date } & \multicolumn{4}{c}{ Water-surface altitude } \\
\cline { 2 - 5 } & $\begin{array}{c}\text { WC 94 } \\
\mathrm{mb}\end{array}$ & $\begin{array}{c}\text { WC 91 } \\
\mathrm{md}\end{array}$ & $\begin{array}{c}\text { WC 92 } \\
\mathrm{mi}\end{array}$ & $\begin{array}{c}\text { WC 93 } \\
\mathrm{ms}\end{array}$ \\
\hline $04 / 08 / 98$ & - & 462.62 & 462.74 & 462.71 \\
$05 / 04 / 98$ & 462.52 & 462.65 & 462.84 & 462.84 \\
$05 / 12 / 98$ & 463.33 & - & - & - \\
$05 / 28 / 98$ & - & - & - & 462.48 \\
$06 / 22 / 98$ & - & 461.87 & 462.06 & 462.09 \\
$06 / 26 / 98$ & 461.51 & - & - & - \\
$07 / 08 / 98$ & 461.67 & - & - & - \\
$07 / 21 / 98$ & 461.26 & - & - & - \\
$07 / 24 / 98$ & 461.41 & 461.55 & 461.76 & 461.83 \\
$09 / 01 / 98$ & 460.54 & 460.67 & 460.84 & 460.85 \\
$10 / 16 / 98$ & 461.53 & 461.66 & 461.84 & 461.97 \\
$12 / 03 / 98$ & 461.04 & 461.18 & 461.37 & 461.51 \\
\hline
\end{tabular}

\begin{tabular}{rlc}
\hline \multirow{2}{*}{ Date } & \multicolumn{2}{c}{ Water-surface altitude } \\
\cline { 2 - 3 } & $\begin{array}{c}\text { WC 97 } \\
\text { md }\end{array}$ & $\begin{array}{c}\text { WC 98 } \\
\text { ms }\end{array}$ \\
\hline $05 / 29 / 98$ & 456.83 & 456.68 \\
$09 / 01 / 98$ & 455.77 & 455.53 \\
$09 / 08 / 98$ & 455.79 & 455.56 \\
$10 / 16 / 98$ & 456.71 & 456.44 \\
$12 / 03 / 98$ & 456.3 & 456.04 \\
\hline
\end{tabular}

\begin{tabular}{ccc} 
& & \\
& & \\
& & \\
Date & \multicolumn{2}{c}{ Water-surface altitude } \\
\cline { 2 - 3 } & $\begin{array}{c}\text { WC 96 } \\
\text { mb }\end{array}$ & $\begin{array}{c}\text { WC } 95 \\
\text { ms }\end{array}$ \\
\hline $04 / 08 / 98$ & - & 473.22 \\
$05 / 28 / 98$ & 471.55 & 473.08 \\
$06 / 04 / 98$ & 471.4 & - \\
$06 / 18 / 98$ & 470.91 & 472.41 \\
$07 / 08 / 98$ & 470.72 & - \\
$07 / 21 / 98$ & - & 471.73 \\
$09 / 01 / 98$ & 468.89 & 470.26 \\
$09 / 08 / 98$ & 468.66 & - \\
$10 / 16 / 98$ & 468.6 & 469.81 \\
$12 / 03 / 98$ & 468.12 & 469.22 \\
\hline
\end{tabular}

\begin{tabular}{cc}
\hline \multirow{2}{*}{ Date } & Water-surface altitude \\
\cline { 2 - 2 } & $\begin{array}{c}\text { WC } 100 \\
\mathrm{mb}\end{array}$ \\
\hline $05 / 26 / 98$ & 536.98 \\
$06 / 25 / 98$ & 534.25 \\
$07 / 27 / 98$ & 533.21 \\
$09 / 01 / 98$ & 527.81 \\
$10 / 16 / 98$ & 530.11 \\
$12 / 03 / 98$ & 532.67 \\
\hline
\end{tabular}

\begin{tabular}{cc}
\hline \multirow{2}{*}{ Date } & Water-surface altitude \\
\cline { 2 - 2 } & $\begin{array}{c}\text { WC } 101 \\
\text { bs }\end{array}$ \\
\hline $05 / 14 / 98$ & 461.32 \\
$06 / 12 / 98$ & 460.14 \\
$07 / 06 / 98$ & 460.05 \\
$07 / 08 / 98$ & 459.94 \\
$07 / 21 / 98$ & 459.52 \\
$08 / 04 / 98$ & 459.31 \\
$09 / 01 / 98$ & 458.94 \\
$09 / 08 / 98$ & 458.96 \\
$09 / 10 / 98$ & 458.92 \\
$10 / 16 / 98$ & 459.86 \\
$12 / 03 / 98$ & 459.41 \\
\hline
\end{tabular}


Appendix 4. Continuous water-level measurements in selected wells in the Nutmeg Valley study area, Wolcott and Waterbury, Connecticut, 1998

[mb, monitoring well in bedrock aquifer; md, monitoring well screened in deepest part of the surficial aquifer; mi, monitoring well screened in intermediate part of the surficial aquifer; ms, monitoring well screened in shallowest part of the surficial aquifer; bs, supply well at a business (unused)]

WC $82(\mathrm{mi})$

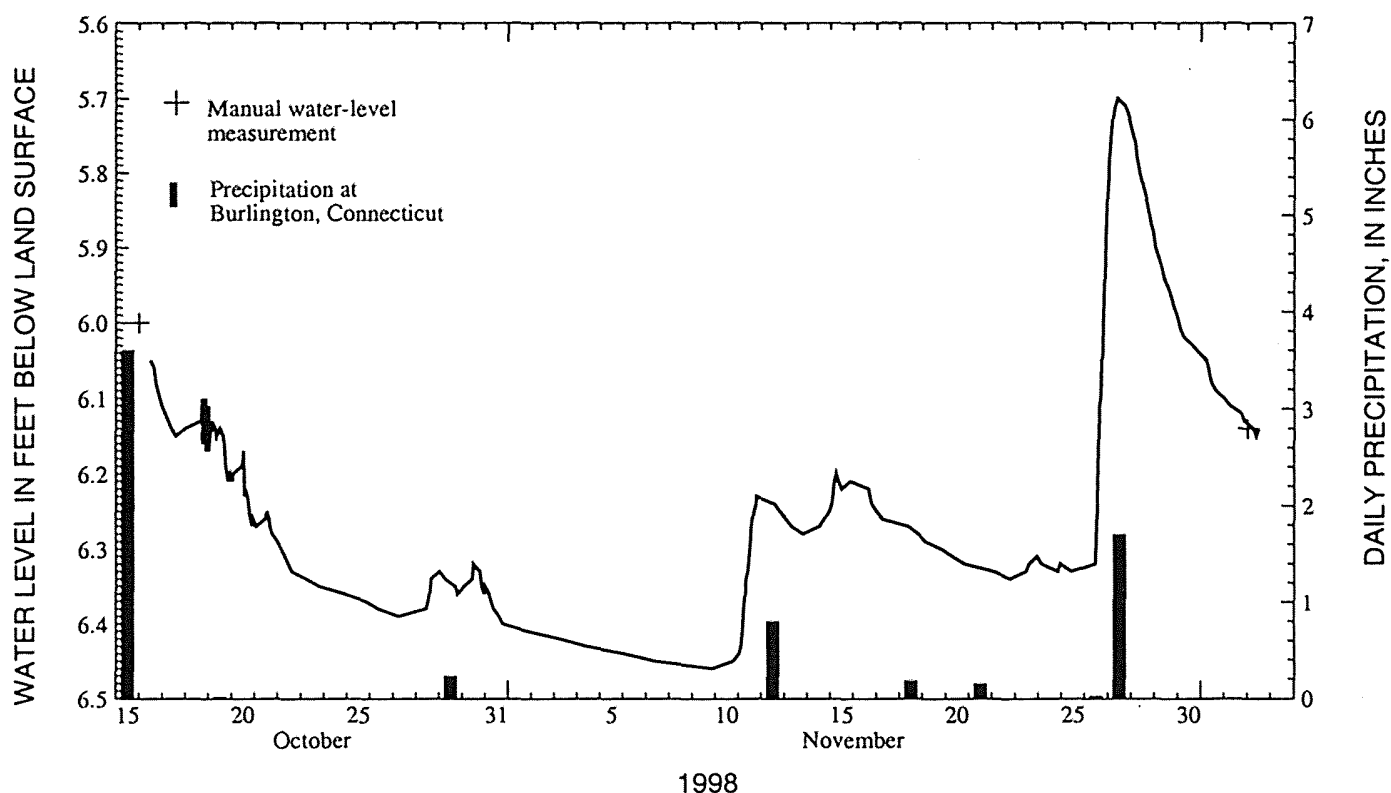

WC $83(\mathrm{mb})$

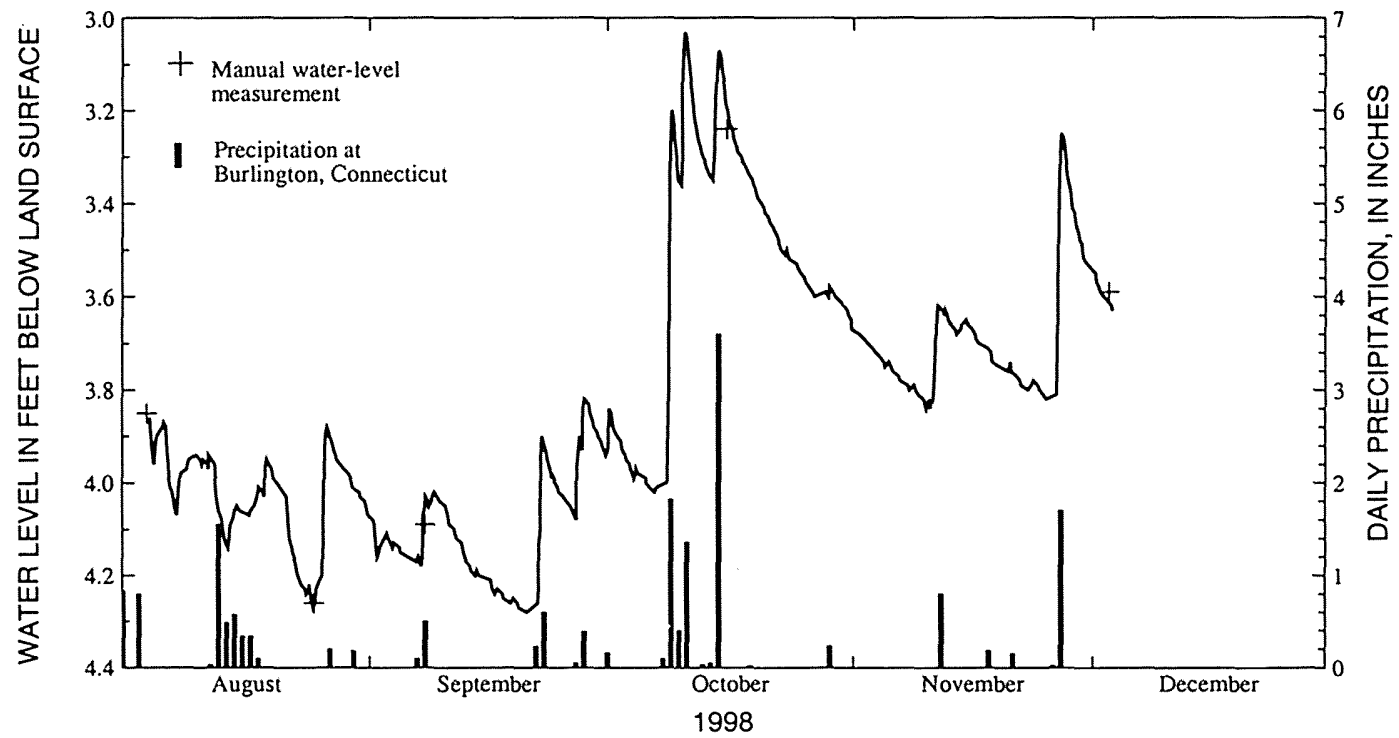




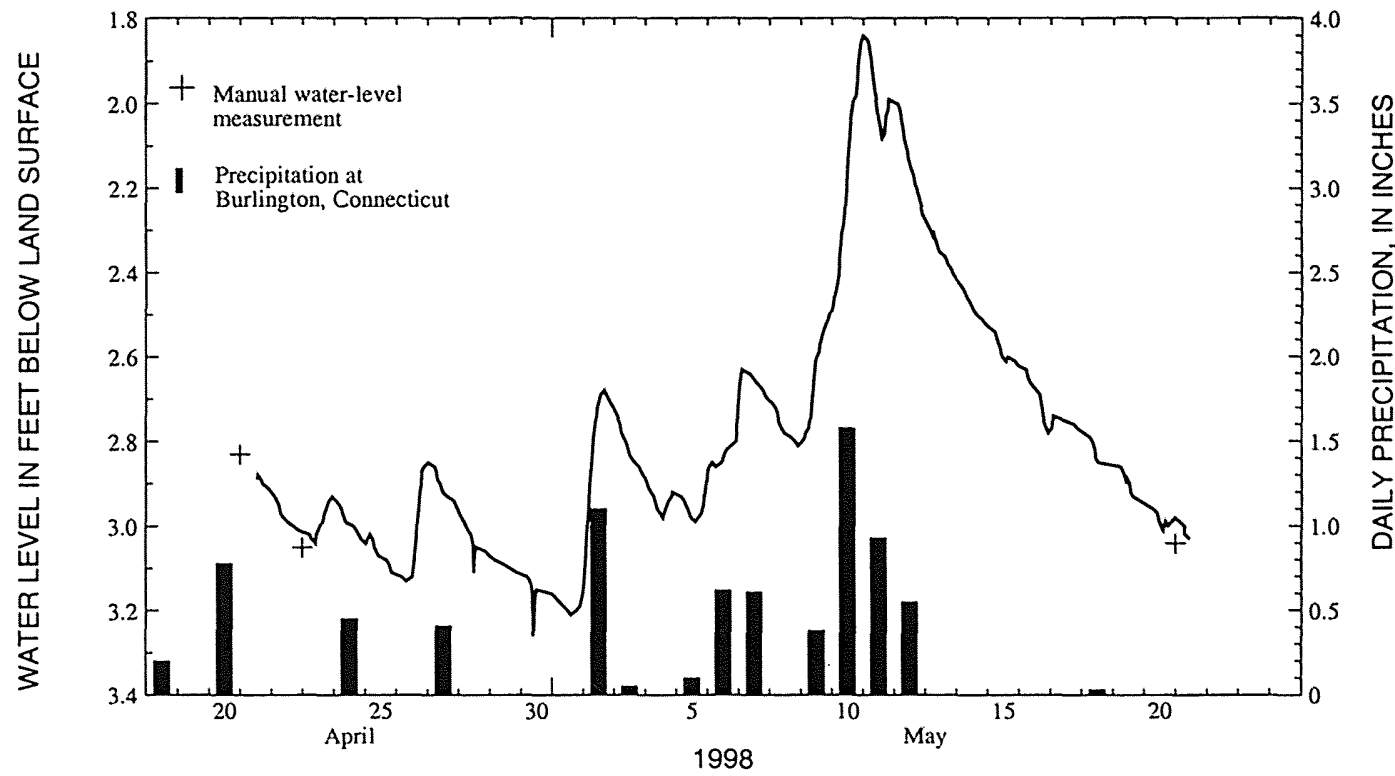

WC 101 (bs)

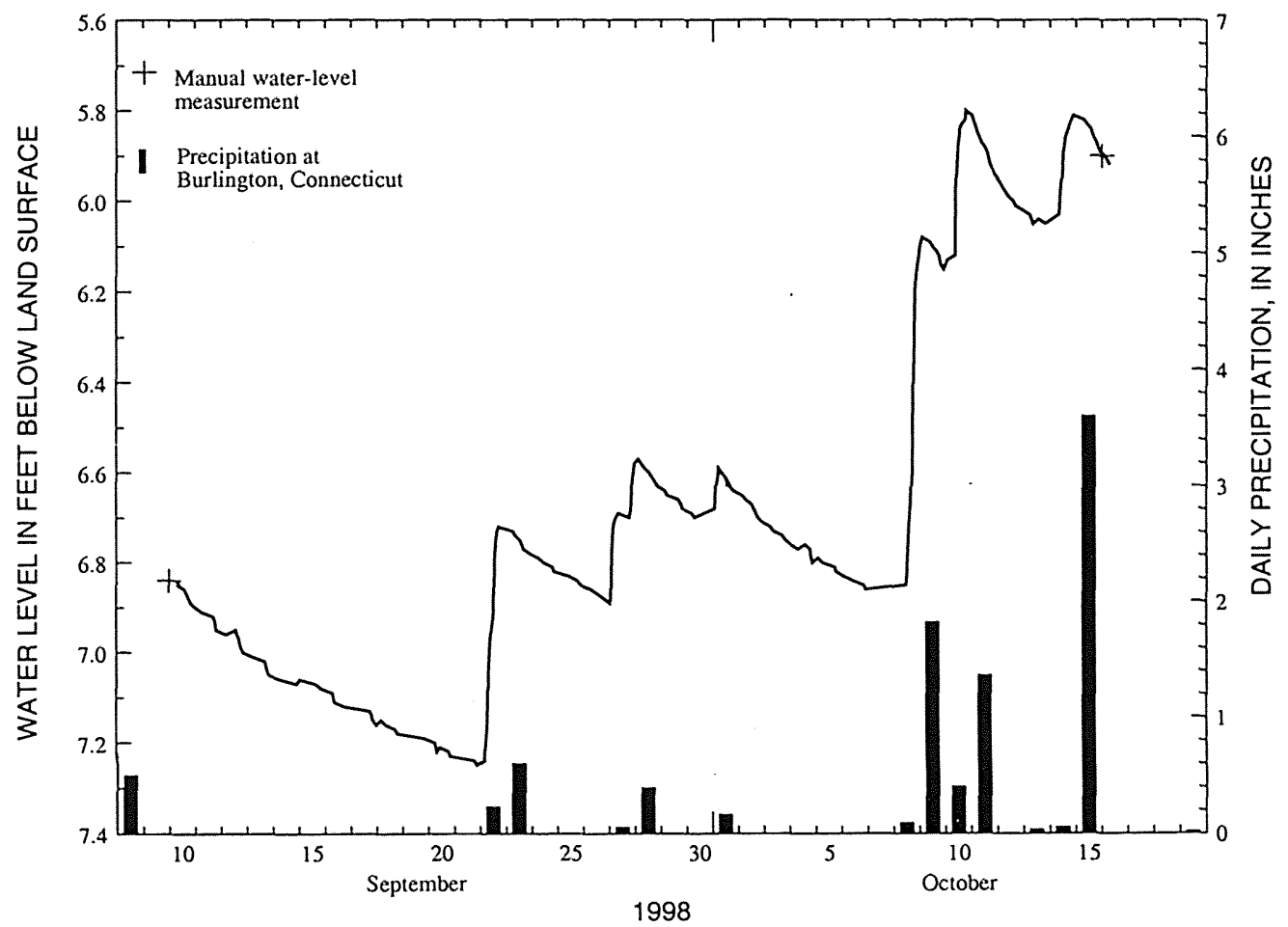


Appendix 5. Rating curves at U.S. Geological Survey streamflow-gaging stations, Nutmeg Valley study area

Unnamed Tributary to Old Tannery Brook at Route 69 (USGS 01208285)

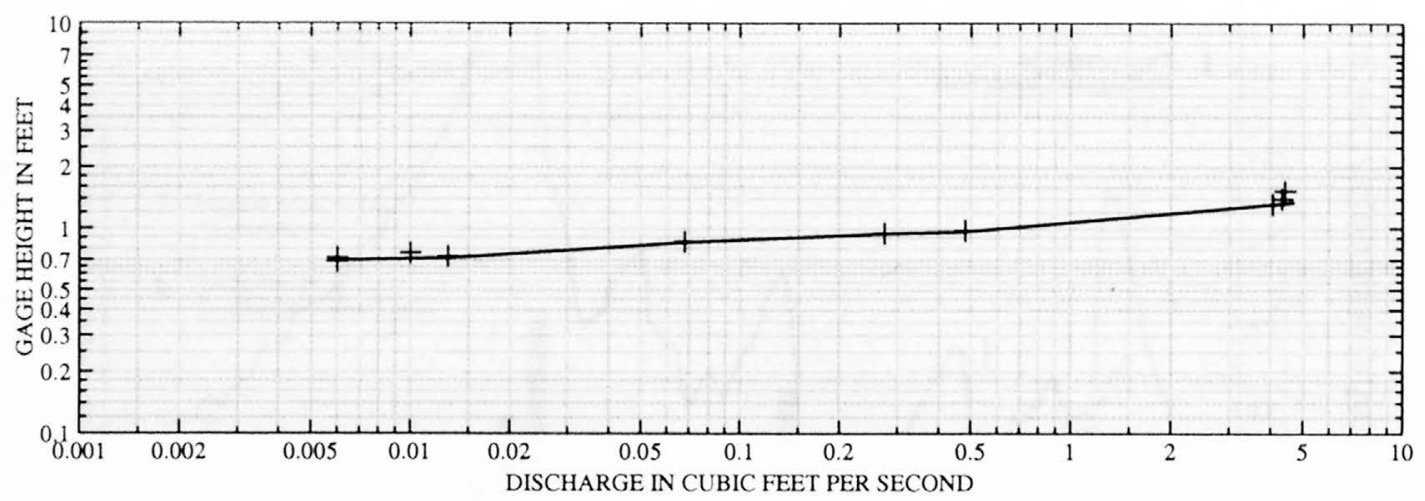

Old Tannery Brook at Tosun Road (USGS 01208280)

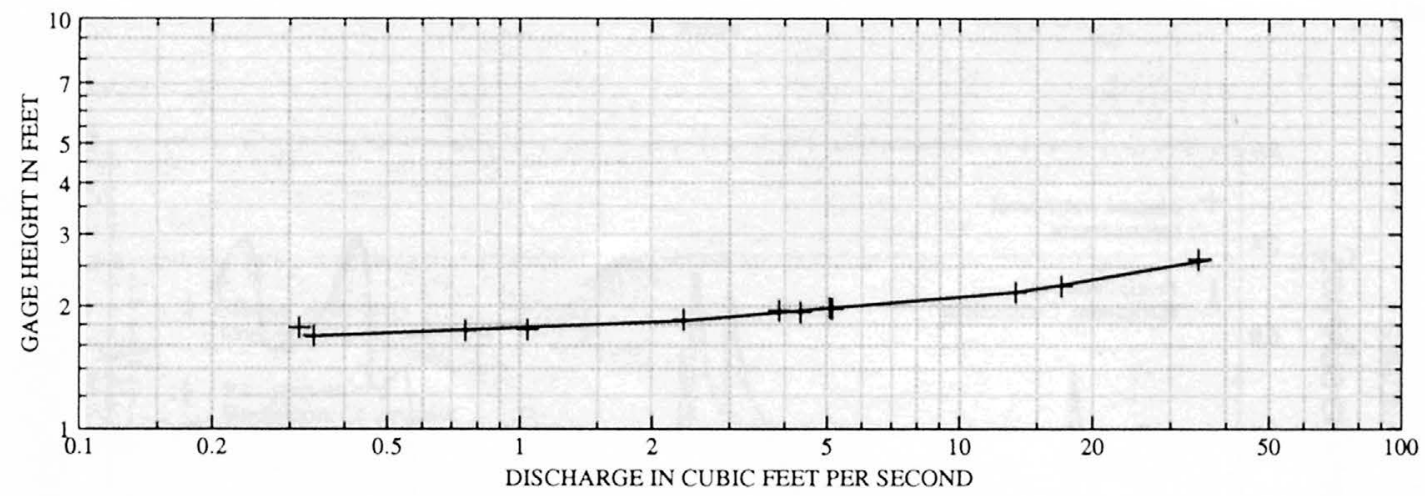


Mad River below Finch Brook (USGS 01208270)
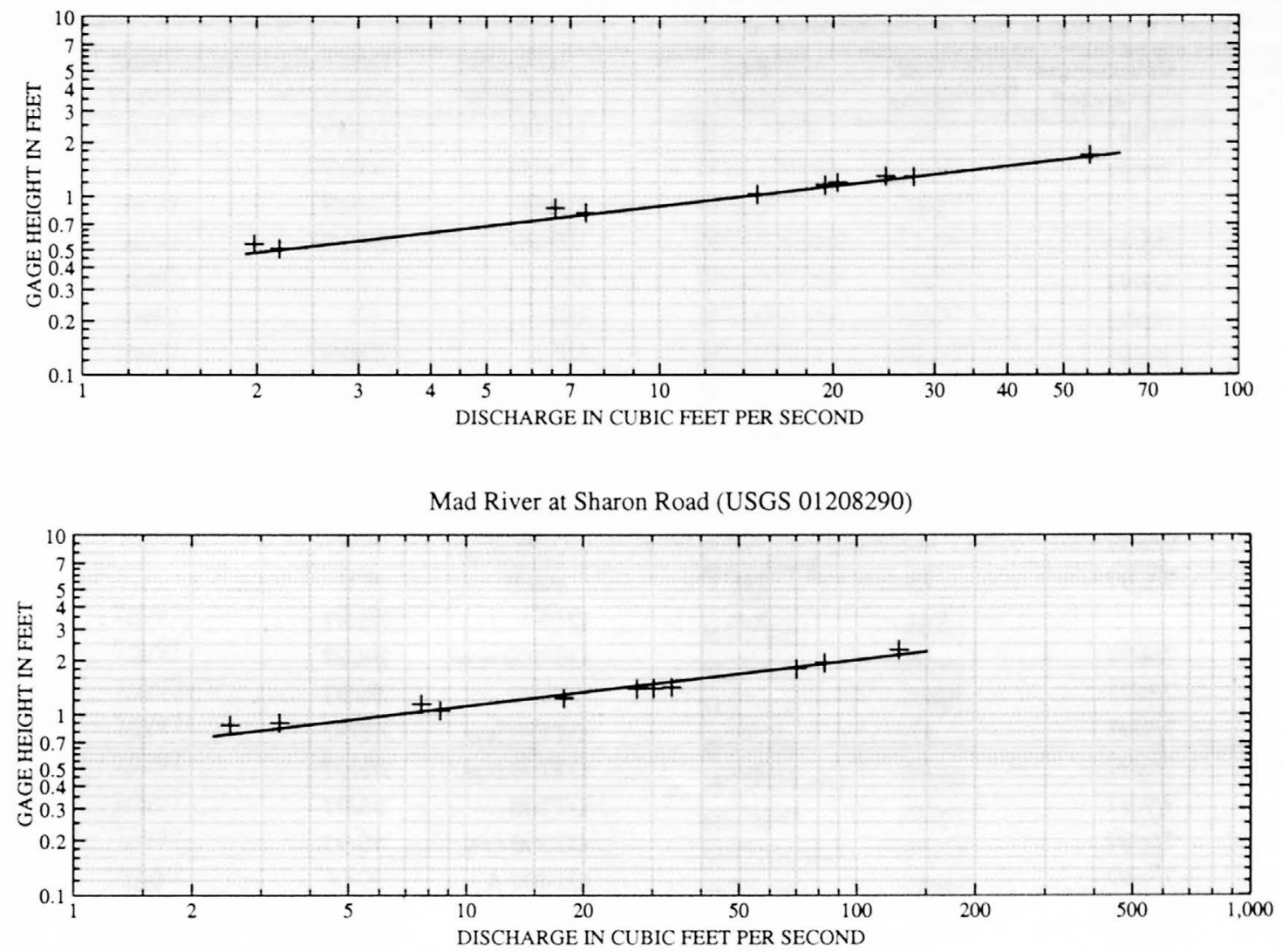

Mad River at Frost Road (USGS 01208295)

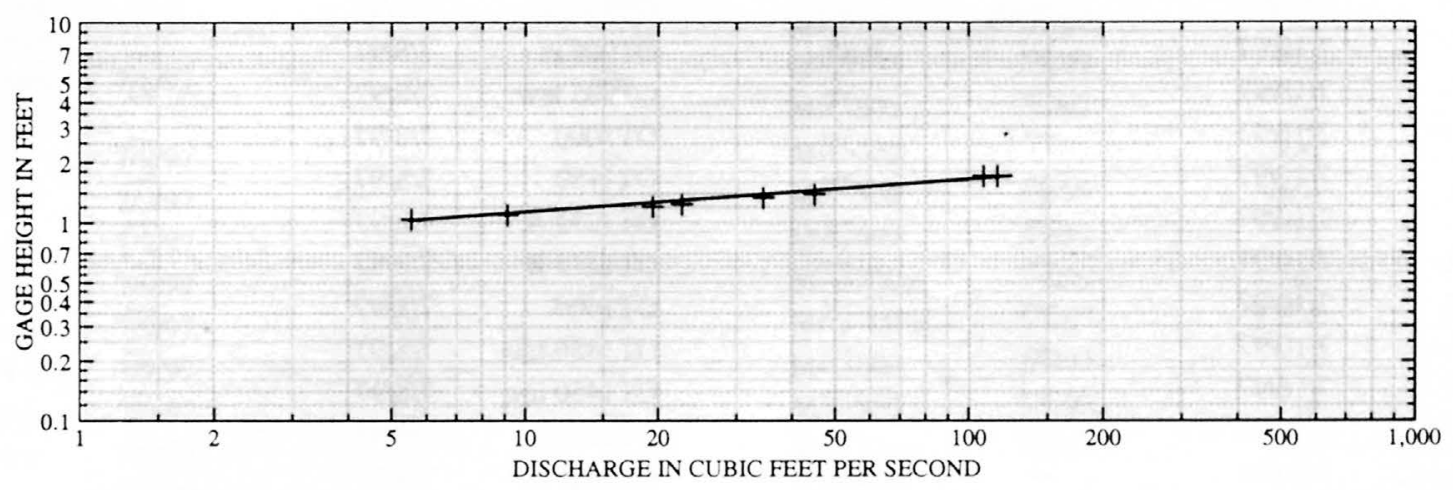


Appendix 6. Vapor-diffusion sampling results in July 1997, Nutmeg Valley study area, Wolcott and Waterbury,

Connecticut

[See plate 1 for locations of sampling sites; TCE, trichloroethene; PCE, tetrachloroethene; $\mathrm{ppb}$, parts per billion by volume; -, no detections above reporting limits; trace, less than or equal to $5 \mathrm{ppb}$; rew, right edge of water looking downstream; lew, left edge of water looking downstream]

\begin{tabular}{|c|c|c|c|}
\hline $\begin{array}{l}\text { Location } \\
\text { identifier }\end{array}$ & $\begin{array}{c}\text { Datesample } \\
\text { analyzed }\end{array}$ & $\begin{array}{l}\text { TCE } \\
\text { (ppb) }\end{array}$ & $\begin{array}{l}\text { PCE } \\
(\mathrm{ppb})\end{array}$ \\
\hline U0 & $7 / 9 / 97$ & - & - \\
\hline U100 & $7 / 9 / 97$ & - & - \\
\hline U200 & & lost & lost \\
\hline U300 & $7 / 9 / 97$ & 一 & - \\
\hline U400 & $7 / 9 / 97$ & - & - \\
\hline U500 A & $7 / 9 / 97$ & - & - \\
\hline U500 B & $7 / 9 / 97$ & - & - \\
\hline U600 & $7 / 9 / 97$ & - & - \\
\hline U700 & $7 / 9 / 97$ & - & trace \\
\hline U900 & $7 / 9 / 97$ & - & 21 \\
\hline U1000 & $7 / 9 / 97$ & - & 34 \\
\hline U1100 & $7 / 9 / 97$ & - & - \\
\hline U1200 & $7 / 9 / 97$ & 73 & 348 \\
\hline U1300 & & lost & lost \\
\hline U1400 & $7 / 9 / 97$ & - & - \\
\hline U1500 & $7 / 9 / 97$ & trace & - \\
\hline $\mathrm{U} 1600 \mathrm{~A}$ & $7 / 9 / 97$ & 17 & trace \\
\hline U1600 B & $7 / 9 / 97$ & 20 & trace \\
\hline U1700 & $7 / 9 / 97$ & - & - \\
\hline U1800 & $7 / 9 / 97$ & - & - \\
\hline U1900 & $7 / 9 / 97$ & 一 & - \\
\hline U2000 & $7 / 9 / 97$ & - & - \\
\hline U2100 & $7 / 9 / 97$ & - & - \\
\hline U2200 & $7 / 9 / 97$ & - & - \\
\hline $\mathrm{U} 2300$ & $7 / 9 / 97$ & - & - \\
\hline $\mathrm{U} 2400 \mathrm{~A}$ & $7 / 9 / 97$ & - & - \\
\hline $\mathrm{U} 2400 \mathrm{~B}$ & $7 / 9 / 97$ & - & - \\
\hline U2500 & $7 / 9 / 97$ & - & - \\
\hline U2600 & $7 / 10 / 97$ & - & trace \\
\hline $\mathrm{U} 2700$ & $7 / 10 / 97$ & - & - \\
\hline U2900 & $7 / 10 / 97$ & - & - \\
\hline U3100 & $7 / 10 / 97$ & - & - \\
\hline U3300 & $7 / 10 / 97$ & - & - \\
\hline $\mathrm{U} 3400 \mathrm{~A}$ & $7 / 10 / 97$ & - & - \\
\hline U3400 B & $7 / 10 / 97$ & - & - \\
\hline U3600 & $7 / 10 / 97$ & - & - \\
\hline U3800 & $7 / 10 / 97$ & - & - \\
\hline U4000 & $7 / 10 / 97$ & - & - \\
\hline $\mathrm{U} 4200$ & $7 / 10 / 97$ & - & trace \\
\hline $\mathrm{U} 4300$ & $7 / 10 / 97$ & - & - \\
\hline U4400 A & $7 / 10 / 97$ & - & - \\
\hline U $4400 \mathrm{~B}$ & $7 / 10 / 97$ & - & trace \\
\hline U4550 & $7 / 10 / 97$ & - & - \\
\hline U4600 & $7 / 10 / 97$ & - & - \\
\hline U4800 & & lost & lost \\
\hline
\end{tabular}

Appendix 6. Vapor-diffusion sampling results in July 1997 , Nutmeg Valley study area, Wolcott and Waterbury, Connecticut--Continued

[See plate 1 for locations of sampling sites; TCE, trichloroethene; PCE, tetrachloroethene; ppb, parts per billion by volume; -, no detections above reporting limits; trace, less than or equal to $5 \mathrm{ppb}$; rew, right edge of water looking downstream; lew, left edge of water looking downstream]

\begin{tabular}{|c|c|c|c|}
\hline $\begin{array}{l}\text { Location } \\
\text { Identifier }\end{array}$ & $\begin{array}{c}\text { Datesample } \\
\text { analyzed }\end{array}$ & $\begin{array}{l}\text { TCE } \\
\text { (ppb) }\end{array}$ & $\begin{array}{l}\text { PCE } \\
\text { (ppb) }\end{array}$ \\
\hline U5000 & $7 / 10 / 97$ & - & - \\
\hline U5100 & $7 / 10 / 97$ & - & - \\
\hline U5200 & $7 / 10 / 97$ & - & - \\
\hline U5300 & $7 / 10 / 97$ & - & - \\
\hline UC & & lost & lost \\
\hline UE & & lost & lost \\
\hline UF 1 & $7 / 10 / 97$ & - & - \\
\hline UF 2 & $7 / 10 / 97$ & - & - \\
\hline $\begin{array}{l}\text { Stream-water } \\
\text { sample at } \\
\text { U5000 }\end{array}$ & $7 / 10 / 97$ & - & - \\
\hline $\begin{array}{l}\text { Stream-water } \\
\text { sample at } \\
\text { site F }\end{array}$ & $7 / 10 / 97$ & 一 & - \\
\hline OT0 & $7 / 8 / 97$ & - & 一 \\
\hline OT 100 rew & $7 / 8 / 97$ & - & - \\
\hline OT190 & $7 / 8 / 97$ & - & 一 \\
\hline OT190 lew & $7 / 8 / 97$ & - & - \\
\hline OT190 rew & $7 / 8 / 97$ & - & - \\
\hline OT200 & $7 / 8 / 97$ & - & 一 \\
\hline OT300 rew & $7 / 8 / 97$ & - & - \\
\hline OT400 A & & lost & lost \\
\hline OT400 B & & lost & lost \\
\hline OT500 rew & $7 / 8 / 97$ & 一 & 一 \\
\hline OT600 & $7 / 8 / 97$ & 一 & 一 \\
\hline OT700 & $7 / 8 / 97$ & 一 & 一 \\
\hline OT800 & $7 / 8 / 97$ & - & - \\
\hline OT900 & $7 / 8 / 97$ & 一 & - \\
\hline OT905 rew & $7 / 8 / 97$ & - & 一 \\
\hline OT905 ct & $7 / 8 / 97$ & 一 & - \\
\hline OT905 lew & $7 / 8 / 97$ & - & - \\
\hline OT1000 & $7 / 8 / 97$ & - & 一 \\
\hline OT 1150 & $7 / 8 / 97$ & 一 & - \\
\hline OT1275 A & $7 / 8 / 97$ & - & - \\
\hline OT1275 B & $7 / 8 / 97$ & 一 & 一 \\
\hline OT1400 & $7 / 8 / 97$ & - & - \\
\hline OT1450 rew & $7 / 8 / 97$ & - & - \\
\hline OT1450 lew & $7 / 8 / 97$ & 一 & 一 \\
\hline OT1500 & $7 / 8 / 97$ & 一 & - \\
\hline OT1625 & $7 / 8 / 97$ & - & 34 \\
\hline OT1700 & $7 / 8 / 97$ & - & 一 \\
\hline OT1800 & $7 / 8 / 97$ & - & - \\
\hline OT1900 & $7 / 8 / 97$ & 一 & 一 \\
\hline OT1930 & $7 / 8 / 97$ & - & 一 \\
\hline OT1930 rew & $7 / 8 / 97$ & 一 & - \\
\hline OT1930 lew & $7 / 8 / 97$ & - & - \\
\hline
\end{tabular}


Appendix 6. Vapor-diffusion sampling results in July 1997, Nutmeg Valley study area, Wolcott and Waterbury, Connecticut--Continued

[See plate 1 for locations of sampling sites; TCE, trichloroethene; PCE, tetrachloroethene; ppb, parts per billion by volume; -, no detections above reporting limits; trace, less than or equal to $5 \mathrm{ppb}$; rew, right edge of water looking downstream; lew, left edge of water looking downstream]

\begin{tabular}{|c|c|c|c|}
\hline $\begin{array}{l}\text { Location } \\
\text { identifier }\end{array}$ & $\begin{array}{c}\text { Datesample } \\
\text { analyzed }\end{array}$ & $\begin{array}{l}\text { TCE } \\
\text { (ppb) }\end{array}$ & $\begin{array}{l}\text { PCE } \\
\text { (ppb) }\end{array}$ \\
\hline OT2000 A & $7 / 8 / 97$ & 45 & - \\
\hline OT2000 B & $7 / 8 / 97$ & 33 & - \\
\hline OT2100 & $7 / 8 / 97$ & 一 & - \\
\hline OT2200 & $7 / 8 / 97$ & - & - \\
\hline OT2275 & $7 / 8 / 97$ & 一 & - \\
\hline OT2350 & $7 / 8 / 97$ & 24 & - \\
\hline OT2350 lew & $7 / 8 / 97$ & 43 & - \\
\hline OT2350 rew & $7 / 8 / 97$ & - & - \\
\hline OT2400 & $7 / 8 / 97$ & - & 一 \\
\hline OT2500 & $7 / 8 / 97$ & - & - \\
\hline OT2600 & $7 / 8 / 97$ & - & - \\
\hline OT2700 A & & lost & lost \\
\hline OT2700 B & & lost & lost \\
\hline OT2800 & $7 / 8 / 97$ & 370 & 200 \\
\hline OT2850 & $7 / 8 / 97$ & trace & - \\
\hline OT2850 rew & $7 / 8 / 97$ & 426 & - \\
\hline OT2850 lew & $7 / 8 / 97$ & 1,480 & - \\
\hline OT2900 & $7 / 8 / 97$ & 4,800 & 320 \\
\hline OT3140 & $7 / 8 / 97$ & 231 & - \\
\hline OT3250 & $7 / 8 / 97$ & 178 & - \\
\hline OT3275 & $7 / 8 / 97$ & trace & 一 \\
\hline OT3275 rew & $7 / 8 / 97$ & - & - \\
\hline OT3275 lew & $7 / 8 / 97$ & - & - \\
\hline $\begin{array}{l}\text { Old Tannery } \\
\text { Brook } \\
\text { stream } \\
\text { water } \\
\text { sample at } \\
\text { Town Line } \\
\text { Rd. culvert }\end{array}$ & $7 / 8 / 97$ & - & - \\
\hline $\begin{array}{r}\text { Stream water } \\
\text { at OT } 3300\end{array}$ & $7 / 8 / 97$ & 6 & - \\
\hline MR0 rew & $7 / 9 / 97$ & 一 & - \\
\hline MR100 rew & $7 / 9 / 97$ & - & - \\
\hline MR200 rew & $7 / 9 / 97$ & 一 & - \\
\hline MR400 rew & $7 / 9 / 97$ & 一 & - \\
\hline MR500 rew & $7 / 9 / 97$ & - & - \\
\hline MR630 A rew & $7 / 9 / 97$ & - & - \\
\hline MR630 B rew & $7 / 9 / 97$ & - & - \\
\hline MR700 rew & $7 / 9 / 97$ & 一 & - \\
\hline MR800 rew & $7 / 9 / 97$ & - & - \\
\hline MR900 & & lost & lost \\
\hline MR 1000 & & lost & lost \\
\hline MR1100 rew & $7 / 9 / 97$ & - & - \\
\hline MR 1200 & $7 / 9 / 97$ & 一 & - \\
\hline MR $1300 \mathrm{~A}$ & $7 / 9 / 97$ & 43 & 48 \\
\hline
\end{tabular}

Appendix 6. Vapor-diffusion sampling results in July 1997 , Nutmeg Valley study area, Wolcott and Waterbury, Connecticut--Continued

[See plate 1 for locations of sampling sites; TCE, trichloroethene; PCE, tetrachloroethene; $\mathrm{ppb}$, parts per billion by volume; - no detections above reporting limits; trace, less than or equal to $5 \mathrm{ppb}$; rew, right edge of water looking downstream; lew, left edge of water looking downstream]

\begin{tabular}{|c|c|c|c|}
\hline $\begin{array}{l}\text { Location } \\
\text { identifier }\end{array}$ & $\begin{array}{c}\text { Datesample } \\
\text { analyzed }\end{array}$ & $\begin{array}{l}\text { TCE } \\
\text { (ppb) }\end{array}$ & $\begin{array}{l}\text { PCE } \\
\text { (ppb) }\end{array}$ \\
\hline MR1300 B & $7 / 9 / 97$ & - & trace \\
\hline MR 1520 rew & $7 / 9 / 97$ & - & - \\
\hline MR1575 & $7 / 9 / 97$ & - & - \\
\hline MR 1800 rew & $7 / 9 / 97$ & 15 & - \\
\hline MR1900 rew & $7 / 9 / 97$ & 一 & - \\
\hline MR2000 rew & $7 / 9 / 97$ & - & - \\
\hline MR2090 & $7 / 9 / 97$ & - & - \\
\hline MR2090 rew & $7 / 9 / 97$ & 31 & trace \\
\hline MR2090 lew & $7 / 9 / 97$ & - & - \\
\hline MR2100 & $7 / 9 / 97$ & 852 & 96 \\
\hline $\begin{array}{l}\mathrm{MR} 2200 \mathrm{~A} \\
\text { rew }\end{array}$ & $7 / 9 / 97$ & 4,700 & 781 \\
\hline $\begin{array}{l}\text { MR2200 B } \\
\text { rew }\end{array}$ & & lost & lost \\
\hline MR2300 & $7 / 9 / 97$ & - & - \\
\hline MR2400 & $7 / 9 / 97$ & 12 & - \\
\hline MR2500 & $7 / 9 / 97$ & 20 & trace \\
\hline MR2600 & $7 / 9 / 97$ & 32 & 24 \\
\hline MR2620 rew & $7 / 9 / 97$ & - & 18 \\
\hline MR2620 & $7 / 9 / 97$ & trace & - \\
\hline MR2620 lew & $7 / 9 / 97$ & 18 & trace \\
\hline MR2780 & $7 / 9 / 97$ & - & - \\
\hline MR2900 & & lost & - lost \\
\hline MR3000 A & & lost & lost \\
\hline MR3000 B & & lost & lost \\
\hline MR3100 & $7 / 9 / 97$ & 47 & - \\
\hline MR3150 rew & $7 / 9 / 97$ & trace & - \\
\hline MR3150 & $7 / 9 / 97$ & 一 & - \\
\hline MR3150 lew & $7 / 9 / 97$ & - & - \\
\hline MR3200 & $7 / 9 / 97$ & - & - \\
\hline MR3300 & $7 / 9 / 97$ & - & - \\
\hline MR3400 & & lost & lost \\
\hline MR3500 & $7 / 9 / 97$ & trace & - \\
\hline MR3600 & $7 / 9 / 97$ & 28 & 29 \\
\hline MR3700 A & $7 / 9 / 97$ & 1,740 & 89 \\
\hline MR3700 B & $7 / 9 / 97$ & 2,050 & 106 \\
\hline MR3800 & $7 / 9 / 97$ & - & - \\
\hline MR3950 & $7 / 9 / 97$ & 216 & 36 \\
\hline $\begin{array}{c}\text { Mad River } \\
\text { stream- } \\
\text { water at } \\
\text { MR200 }\end{array}$ & $7 / 9 / 97$ & - & - \\
\hline
\end{tabular}


Appendix 7. Vapor-diffusion sampling results in November 1997, Nutmeg Valley study area, Wolcott and Waterbury, Connecticut

[See plate I for locations of sampling sites; TCE, trichloroethene; PCE, tetrachloroethene; $c$ 1,2-DCE, cis 1,2-Dichloroethene; ppb, parts per billion by volume; -, no detections above reporting limits; y, detected but not quantified; trace, less than or equal to $25 \mathrm{ppb}$; rew, right edge of water looking downstream; lew, left edge of water looking downstream; >, greater than]

\begin{tabular}{|c|c|c|c|c|c|}
\hline Location identifier & $\begin{array}{c}\text { Date sample } \\
\text { analyzed }\end{array}$ & $\begin{array}{l}\text { TCE } \\
(\mathrm{ppb})\end{array}$ & $\begin{array}{l}\text { PCE } \\
(\mathrm{ppb})\end{array}$ & $c 1,2-\mathrm{DCE}$ & $\begin{array}{c}\text { Benzene } \\
\text { (ppb) }\end{array}$ \\
\hline$\overline{\mathrm{U} 0}$ & $11 / 12 / 97$ & - & - & - & - \\
\hline U100 & $11 / 12 / 97$ & - & - & - & - \\
\hline U400 & $11 / 12 / 97$ & - & - & - & - \\
\hline U500 & $11 / 12 / 97$ & - & - & - & - \\
\hline $\mathrm{U} 600$ & $11 / 12 / 97$ & - & - & - & - \\
\hline U700 & $11 / 12 / 97$ & - & - & - & - \\
\hline U800 & $11 / 12 / 97$ & - & - & - & - \\
\hline U900 & $11 / 12 / 97$ & - & - & - & - \\
\hline U1000 & $11 / 12 / 97$ & - & - & - & - \\
\hline U1100 & $11 / 12 / 97$ & - & - & - & - \\
\hline U1200 A & $11 / 12 / 97$ & - & - & - & - \\
\hline U1200 B & $11 / 12 / 97$ & - & - & - & - \\
\hline U1300 & $11 / 12 / 97$ & - & - & - & - \\
\hline U1400 & $11 / 12 / 97$ & - & - & - & - \\
\hline U1500 & $11 / 12 / 97$ & - & - & - & - \\
\hline U1600 A & $11 / 13 / 97$ & 104 & 101 & $y$ & - \\
\hline U1600 B & $11 / 13 / 97$ & 93 & 93 & $y$ & - \\
\hline U1700 & $11 / 13 / 97$ & - & 65 & - & - \\
\hline U1800 & $11 / 13 / 97$ & - & - & $y$ & - \\
\hline U1900 & $11 / 13 / 97$ & - & 60 & $y$ & - \\
\hline U2000 & $11 / 13 / 97$ & - & - & y & - \\
\hline U2100 & $11 / 13 / 97$ & - & - & $y$ & - \\
\hline U2200 & $11 / 13 / 97$ & trace & 一 & - & - \\
\hline $\mathrm{U} 2700$ & $11 / 13 / 97$ & - & - & - & - \\
\hline Stream-water sample at U0 & $11 / 12 / 97$ & - & - & - & - \\
\hline $\begin{array}{l}\text { Stream-water sample at upstream side } \\
\text { of Rt. } 69 \text { culvert }\end{array}$ & $11 / 12 / 97$ & - & - & - & - \\
\hline OT0 & $11 / 13 / 97$ & - & 153 & - & - \\
\hline OT100 lew & $11 / 13 / 97$ & - & - & - & - \\
\hline OT190 & & lost & lost & lost & lost \\
\hline OT300 rew & $11 / 13 / 97$ & - & - & - & - \\
\hline OT $400 \mathrm{~A}$ & & lost & lost & lost & lost \\
\hline OT400 B & & lost & lost & lost & lost \\
\hline OT500 rew & $11 / 13 / 97$ & - & - & - & - \\
\hline OT600 & $11 / 13 / 97$ & - & - & - & - \\
\hline OT700 & $11 / 13 / 97$ & - & 一 & - & - \\
\hline OT800 & $11 / 13 / 97$ & - & - & $\mathrm{y}$ & - \\
\hline OT900 & $11 / 13 / 97$ & - & - & - & - \\
\hline OT1000 & $11 / 13 / 97$ & - & - & - & 47 \\
\hline OT1150 & & lost & lost & lost & lost \\
\hline OT1275 & $11 / 13 / 97$ & - & - & - & - \\
\hline OT1325 & $11 / 13 / 97$ & - & - & - & - \\
\hline OT 1400 & $11 / 13 / 97$ & - & - & - & - \\
\hline OT 1500 & & lost & lost & lost & lost \\
\hline OT1625 & $11 / 12 / 97$ & - & - & - & - \\
\hline OT1625 rew & $11 / 12 / 97$ & - & - & - & - \\
\hline
\end{tabular}


Appendix 7. Vapor-diffusion sampling results in November 1997, Nutmeg Valley study area, Wolcott and Waterbury, Connecticut--Continued

[See plate 1 for locations of sampling sites; TCE, trichloroethene; PCE, tetrachloroethene; $c$ 1,2-DCE, cis 1,2-Dichloroethene; ppb, parts per billion by volume; - no detections above reporting limits; y, detected but not quantified; trace, less than or equal to 25 ppb; rew, right edge of water looking downstream; lew, left edge of water looking downstream; >, greater than]

\begin{tabular}{|c|c|c|c|c|c|}
\hline Location identifier & $\begin{array}{c}\text { Date sample } \\
\text { analyzed }\end{array}$ & $\begin{array}{l}\text { TCE } \\
\text { (ppb) }\end{array}$ & $\begin{array}{l}\text { PCE } \\
\text { (ppb) }\end{array}$ & C 1,2-DCE & $\begin{array}{c}\text { Benzene } \\
\text { (ppb) }\end{array}$ \\
\hline OT1625 lew & $11 / 12 / 97$ & - & - & - & 一 \\
\hline OT1700 & $11 / 12 / 97$ & - & - & - & - \\
\hline OT 1800 & $11 / 12 / 97$ & - & - & - & - \\
\hline OT1930 lew & & lost & lost & lost & lost \\
\hline OT2000 lew & $11 / 12 / 97$ & 78 & - & 一 & - \\
\hline OT2000 & $11 / 12 / 97$ & 25 & - & y & - \\
\hline OT2000 rew & $11 / 12 / 97$ & - & - & - & trace \\
\hline OT2100 & $11 / 12 / 97$ & 57 & - & - & - \\
\hline OT2275 & $11 / 12 / 97$ & 34 & - & - & - \\
\hline OT2350 & $11 / 12 / 97$ & trace & - & - & - \\
\hline OT2350 rew & $11 / 12 / 97$ & - & - & - & - \\
\hline OT2350 lew $\mathrm{A}$ & $11 / 12 / 97$ & 37 & - & - & - \\
\hline OT2350 lew B & $11 / 12 / 97$ & 39 & - & - & - \\
\hline OT2400 & $11 / 12 / 97$ & - & - & - & - \\
\hline OT2500 & $11 / 12 / 97$ & - & - & - & - \\
\hline OT2550 & $11 / 12 / 97$ & - & - & y & - \\
\hline OT2600 & $11 / 12 / 97$ & - & - & - & - \\
\hline OT2670 lew & $11 / 12 / 97$ & - & - & - & - \\
\hline OT2670 & $11 / 12 / 97$ & 160 & - & y & - \\
\hline OT2670 rew & $11 / 12 / 97$ & 57 & - & y & - \\
\hline OT2800 A & $11 / 12 / 97$ & 263 & 246 & y & - \\
\hline OT2800 B & & lost & lost & lost & lost \\
\hline OT2850 & $11 / 12 / 97$ & trace & - & - & - \\
\hline OT2850 lew & $11 / 12 / 97$ & 1,065 & - & $y$ & - \\
\hline OT2850 rew & $11 / 12 / 97$ & 77 & - & y & 一 \\
\hline OT2900 lew & $11 / 12 / 97$ & $>30,000$ & - & $y$ & - \\
\hline OT2900 & $11 / 12 / 97$ & 789 & - & y & - \\
\hline OT2900 rew & $11 / 12 / 97$ & - & - & y & - \\
\hline OT2970 & $11 / 12 / 97$ & 63 & - & $y$ & - \\
\hline OT3140 lew & & lost & lost & lost & lost \\
\hline OT3140 & & lost & lost & lost & lost \\
\hline OT3140 rew & $11 / 12 / 97$ & 36 & - & - & - \\
\hline OT3170 & $11 / 12 / 97$ & 36 & - & - & - \\
\hline OT3250 lew & $11 / 12 / 97$ & 316 & - & $y$ & - \\
\hline OT3250 & $11 / 12 / 97$ & - & - & - & - \\
\hline OT3250 rew & $11 / 12 / 97$ & - & - & - & 一 \\
\hline OT3275 & $11 / 12 / 97$ & - & - & - & - \\
\hline OT3275 lew & $11 / 12 / 97$ & 3,400 & - & - & - \\
\hline $\begin{array}{l}\text { Stream water at Town Line Rd. } \\
\text { culvert, OT } 2400\end{array}$ & $11 / 12 / 97$ & - & - & - & - \\
\hline Ground-water sample at OT2850 lew & $11 / 12 / 97$ & 113 & - & - & 一 \\
\hline Stream-water sample at OT3275 & $11 / 12 / 97$ & - & - & - & - \\
\hline MR200 rew & $11 / 13 / 97$ & - & - & - & 51 \\
\hline MR400 rew & $11 / 13 / 97$ & - & - & - & trace \\
\hline MR600 & $11 / 13 / 97$ & - & trace & - & - \\
\hline MR800 rew & $11 / 13 / 97$ & - & 47 & - & trace \\
\hline
\end{tabular}


Appendix 7. Vapor-diffusion sampling results in November 1997, Nutmeg Valley study area, Wolcott and Waterbury, Connecticut--Continued

[See plate 1 for locations of sampling sites; TCE, trichloroethene; PCE, tetrachloroethene; $c$ 1,2-DCE, cis 1,2-Dichloroethene; ppb, parts per billion by volume; -, no detections above reporting limits; $y$, detected but not quantified; trace, less than or equal to $25 \mathrm{ppb}$; rew, right edge of water looking downstream; lew, left edge of water looking downstream; >, greater than]

\begin{tabular}{|c|c|c|c|c|c|}
\hline Location identifier & $\begin{array}{c}\text { Date sample } \\
\text { analyzed }\end{array}$ & $\begin{array}{l}\text { TCE } \\
\text { (ppb) }\end{array}$ & $\begin{array}{l}\text { PCE } \\
\text { (ppb) }\end{array}$ & $c 1,2-D C E$ & $\begin{array}{c}\text { Benzene } \\
(\mathrm{ppb})\end{array}$ \\
\hline MR1000 & $11 / 13 / 97$ & - & - & - & - \\
\hline MR1200 & $11 / 13 / 97$ & - & - & - & - \\
\hline MR1300 A & $11 / 13 / 97$ & - & - & - & - \\
\hline MR1300 B & $11 / 13 / 97$ & - & - & - & - \\
\hline MR1400 & $11 / 13 / 97$ & - & trace & - & - \\
\hline MR1500 & $11 / 13 / 97$ & - & 106 & - & - \\
\hline MR1590 & $11 / 13 / 97$ & - & - & - & - \\
\hline MR1710 & $11 / 13 / 97$ & - & - & - & - \\
\hline MR1800 rew & $11 / 13 / 97$ & 36 & - & $y$ & - \\
\hline MR1900 rew & $11 / 13 / 97$ & - & - & $y$ & - \\
\hline MR2000 rew & $11 / 13 / 97$ & - & - & - & - \\
\hline MR2100 rew & $11 / 13 / 97$ & - & - & - & - \\
\hline MR2100 A & $11 / 13 / 97$ & - & - & - & - \\
\hline MR2100 B & $11 / 13 / 97$ & - & - & - & - \\
\hline MR2100 lew & $11 / 13 / 97$ & - & - & - & - \\
\hline MR2200 rew & $11 / 13 / 97$ & 1,200 & 190 & $y$ & - \\
\hline MR2200 A & $11 / 13 / 97$ & - & - & y & - \\
\hline MR2200 B & $11 / 13 / 97$ & - & - & $y$ & - \\
\hline MR2200 lew & $11 / 13 / 97$ & 520 & 390 & - & - \\
\hline MR2400 & $11 / 13 / 97$ & - & - & - & trace \\
\hline MR2500 rew & $11 / 13 / 97$ & trace & - & - & - \\
\hline MR2600 rew & $11 / 13 / 97$ & - & - & - & - \\
\hline MR2900 & $11 / 13 / 97$ & trace & - & - & trace \\
\hline MR3100 rew & $11 / 13 / 97$ & & & $y$ & 31 \\
\hline MR3100 A & $11 / 13 / 97$ & - & - & - & trace \\
\hline MR3100 B & $11 / 13 / 97$ & - & - & - & - \\
\hline MR3100 lew & $11 / 13 / 97$ & 20 & - & - & - \\
\hline MR3300 & $11 / 13 / 97$ & - & - & y & - \\
\hline MR3500 & $11 / 13 / 97$ & 8,000 & - & $y$ & - \\
\hline MR3600 & $11 / 13 / 97$ & 2,940 & - & $y$ & - \\
\hline MR3700 A & $11 / 13 / 97$ & 137 & 126 & $y$ & - \\
\hline MR3700 B & $11 / 13 / 97$ & 126 & - & y & - \\
\hline MR3700 rew & $11 / 13 / 97$ & - & - & - & - \\
\hline MR3700 lew & $11 / 13 / 97$ & 702 & - & $y$ & - \\
\hline MR3950 & $11 / 13 / 97$ & - & - & - & - \\
\hline MR4000 & $11 / 13 / 97$ & trace & - & - & - \\
\hline MR4100 rew B & $11 / 13 / 97$ & - & - & - & trace \\
\hline MR4100 rew A & $11 / 13 / 97$ & - & - & - & trace \\
\hline MR4200 & $11 / 13 / 97$ & - & - & - & - \\
\hline MR4200 rew & $11 / 13 / 97$ & - & - & - & - \\
\hline MR4200 lew & $11 / 13 / 97$ & - & - & - & - \\
\hline MR4300 & $11 / 13 / 97$ & - & - & - & - \\
\hline MR4400 & $11 / 13 / 97$ & - & - & y & - \\
\hline Stream-water sample at MR300 & $11 / 13 / 97$ & - & - & - & - \\
\hline Stream-water sample at MR4000 & $11 / 13 / 97$ & - & - & - & - \\
\hline
\end{tabular}


Appendix 8. Selected characteristics of wells inventoried/installed by the U.S. Geological Survey

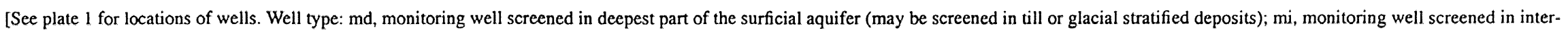

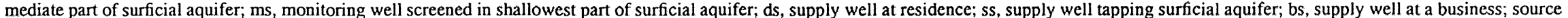

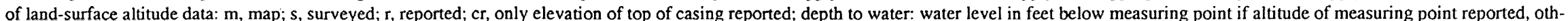
erwise water level in feet below land surface; $>$, greater than; - , data not available]

\begin{tabular}{|c|c|c|c|c|c|c|c|c|c|c|c|c|c|c|c|c|c|c|c|c|}
\hline $\begin{array}{c}\text { U.S. Geo- } \\
\text { logical } \\
\text { Survey } \\
\text { identifier }\end{array}$ & $\begin{array}{l}\text { Other name or } \\
\text { property owner }\end{array}$ & & $\begin{array}{l}\text { Latitu } \\
\text { (degre } \\
\text { minu } \\
\text { secon }\end{array}$ & & & $\begin{array}{l}\text { ong } \\
\text { deg } \\
\text { mint } \\
\text { eco }\end{array}$ & $\begin{array}{l}\text { ude } \\
\text { ees } \\
\text { tes } \\
\text { ids) }\end{array}$ & 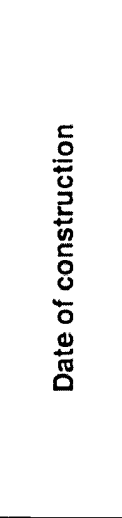 & $\frac{\stackrel{0}{0}}{\frac{0}{2}}$ & 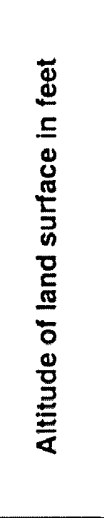 & 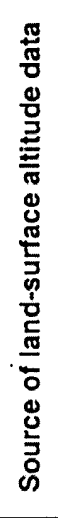 & 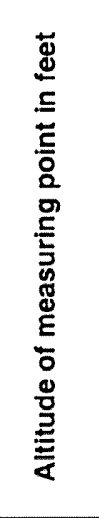 & 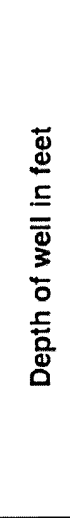 & 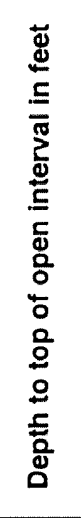 & 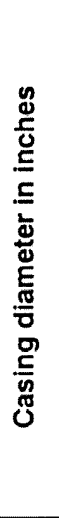 & 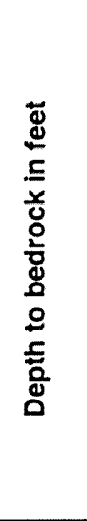 & 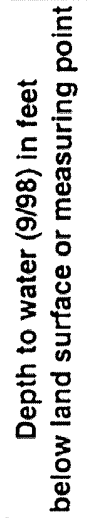 & 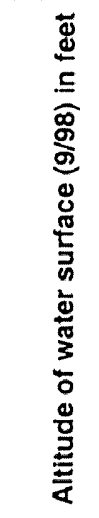 & 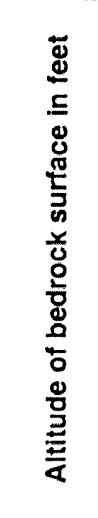 & $\begin{array}{l}\text { Source of } \\
\text { well con- } \\
\text { struction } \\
\text { data }\end{array}$ \\
\hline WB 344 & Cly-Del well 1 & 41 & 34 & 8 & 73 & 0 & 15 & $12 / 09 / 56$ & ss & 460 & $\mathrm{~m}$ & $=$ & 35 & 35 & 8 & $>35$ & - & - & - & $\begin{array}{l}\text { Well comple } \\
\text { tion report }\end{array}$ \\
\hline WB 345 & Cly-Del well 2 & 41 & 34 & 7 & 73 & 0 & 1 & $12 / 09 / 56$ & ss & 455 & $\mathrm{~m}$ & - & 40 & 34 & 8 & $>40$ & - & - & - & $\begin{array}{l}\text { Well comple- } \\
\text { tion report }\end{array}$ \\
\hline WB 346 & Cly-Del well 3 & 41 & 34 & 4 & 73 & 0 & 5 & $12 / 09 / 56$ & ss & 455 & $\mathrm{~m}$ & - & 44 & 27 & 8 & 44 & - & - & 411 & $\begin{array}{l}\text { Well comple- } \\
\text { tion report }\end{array}$ \\
\hline WB 393 & $\begin{array}{l}63 \text { Wakelee Rd. } \\
\text { Amp RFW-1 }\end{array}$ & 41 & 34 & 26.8 & 73 & 0 & 10 & $11 / 10 / 95$ & $\mathrm{~ms}$ & 497.58 & s & - & 18 & 8 & 4 & $>18$ & 9.11 & 488.47 & - & $\begin{array}{l}\text { Roy F. } \\
\text { Weston, } \\
1996\end{array}$ \\
\hline WB 397 & Highland MW-9S & 41 & 34 & 23 & 73 & 0 & 5.2 & $03 / 16 / 90$ & $\mathrm{~ms}$ & 481.47 & $r$ & - & 20 & 10 & 2 & $>20$ & 14.37 & 467.10 & - & HRP, 1996b \\
\hline WB 398 & Highland MW-9D & 41 & 34 & 23 & 73 & 0 & 5.3 & $03 / 14 / 90$ & md & 481.73 & $r$ & - & 45 & 35 & 2 & 45 & - & - & 436.73 & HRP, $1996 \mathrm{~b}$ \\
\hline WB 399 & Highland MW-8D & 41 & 34 & 22.1 & 73 & 0 & 5.6 & $03 / 13 / 90$ & md & 484.24 & $r$ & - & 42 & 28 & 2 & 42 & - & - & 442.24 & $\mathrm{HRP}, 1996 \mathrm{~b}$ \\
\hline WB 400 & Highland MW-8S & 41 & 34 & 22.2 & 73 & 0 & 5.5 & $03 / 16 / 90$ & $\mathrm{~ms}$ & 483.58 & $r$ & - & 23 & 12.5 & 2 & $>23$ & 18.44 & 465.14 & - & HRP, 1996b \\
\hline WB 401 & Highland MW-7D & 41 & 34 & 24.8 & 73 & 0 & 9.2 & $03 / 13 / 90$ & md & 497.04 & r & - & 50 & 38.5 & 2 & $>48.5$ & 9.38 & 487.66 & - & HRP, 1996b \\
\hline WB 402 & Highland MW-7S & 41 & 34 & 24.8 & 73 & 0 & 9.2 & $01 / 24 / 90$ & $\mathrm{~ms}$ & 497.37 & $r$ & - & 20 & 2 & 2 & $>20$ & 8.13 & 489.24 & - & HRP, 1996b \\
\hline WB 403 & MW-F, NEDA & 41 & 34 & 24.9 & 73 & 0 & 22.2 & - & $\mathrm{mb}$ & 574.62 & $s$ & - & - & - & - & - & 30.46 & 544.16 & - & AEI, 1994 \\
\hline WB 404 & U.S. Postal Service & 41 & 34 & 13.2 & 73 & 0 & 10.3 & $03 / 31 / 98$ & md & 470.37 & $\mathrm{~s}$ & 470.18 & 50 & 48.45 & 2 & 51 & 12.47 & 457.71 & 41.9 .37 & USGS \\
\hline WB 405 & U.S. Postal Service & 41 & 34 & 13.2 & 73 & 0 & 10.3 & $03 / 31 / 98$ & $\mathrm{mi}$ & 470.43 & $s$ & 470.21 & 31 & 28.74 & 2 & 51 & 11.8 & 458.41 & 419.43 & USGS \\
\hline WB 406 & U.S. Postal Service & 41 & 34 & 13.2 & 73 & 0 & 10.3 & $03 / 31 / 98$ & $\mathrm{~ms}$ & 470.37 & s & 470.29 & 19 & 16.91 & 2 & 51 & 12.21 & 458.08 & 419.37 & USGS \\
\hline WB 407 & U.S. Postal Service & 41 & 34 & 13.2 & 73 & 0 & 10.3 & $04 / 30 / 98$ & $\mathrm{mb}$ & 470.34 & $s$ & 470.7 & 160 & 76 & 6 & 51 & 10.45 & 460.25 & 419.34 & USGS \\
\hline WB 408 & Highland MW-10 & 41 & 34 & 20.9 & 73 & 0 & 2.5 & $07 / 18 / 90$ & md & 479.51 & $\mathrm{cr}$ & - & 77 & 66 & 2 & 77 & - & - & 402.51 & HRP, 1996b \\
\hline WB 409 & Highland BR-1 & 41 & 34 & 20.9 & 73 & 0 & 2.6 & $07 / 02 / 90$ & $\mathrm{mb}$ & 479.51 & $\mathrm{cr}$ & - & 98 & 91 & 3 & 86.5 & - & - & 393.01 & HRP, 1996b \\
\hline WB 410 & Spring & 41 & 34 & 32.6 & 73 & 0 & 15 & & spring & 565 & $\mathrm{~m}$ & - & - & - & - & - & - & - & - & - \\
\hline
\end{tabular}


Appendix 8. Selected characteristics of wells inventoried/installed by the U.S. Geological Survey--Continued

[See plate 1 for locations of wells. Well type: md, monitoring well screened in deepest part of the surficial aquifer (may be screened in till or glacial stratifed deposits); mi, monitoring well screened in inter-

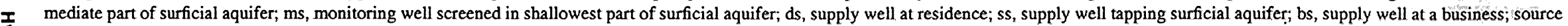

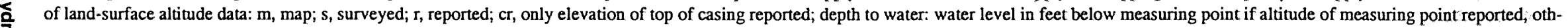
erwise water level in feet below land surface; >, greater than; - , data not available]

\begin{tabular}{|c|c|c|c|c|c|c|c|c|c|c|c|c|c|c|c|c|c|c|c|c|}
\hline $\begin{array}{l}\text { U.S. Geo- } \\
\text { logical } \\
\text { Survey } \\
\text { identifier }\end{array}$ & $\begin{array}{l}\text { Other name or } \\
\text { property owner }\end{array}$ & \multicolumn{3}{|c|}{$\begin{array}{l}\text { Latitude } \\
\text { (degrees } \\
\text { minutes } \\
\text { seconds) }\end{array}$} & \multicolumn{3}{|c|}{$\begin{array}{l}\text { Longitude } \\
\text { (degrees } \\
\text { minutes } \\
\text { seconds) }\end{array}$} & 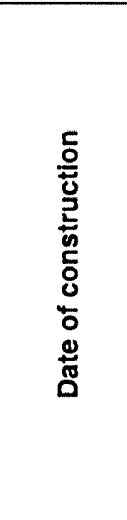 & $\frac{\stackrel{2}{2}}{\overline{\overline{0}}}$ & \multirow[t]{2}{*}{ 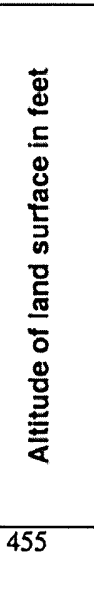 } & \multirow[t]{2}{*}{ 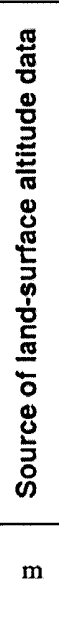 } & \multirow[t]{2}{*}{ 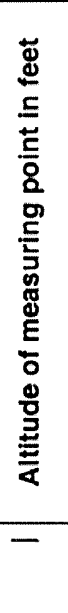 } & \multirow[t]{2}{*}{ 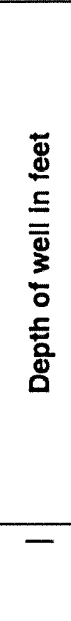 } & \multirow[t]{2}{*}{ 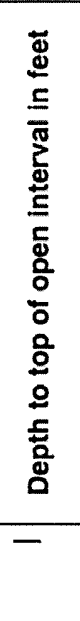 } & \multirow[t]{2}{*}{ 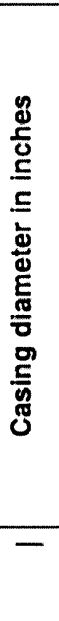 } & \multirow[t]{2}{*}{ 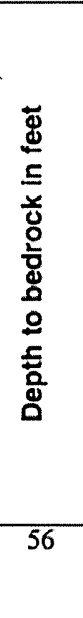 } & \multirow[t]{2}{*}{ 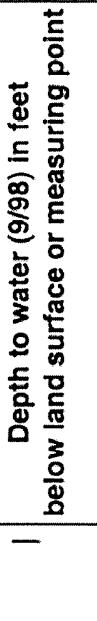 } & \multirow[t]{2}{*}{ 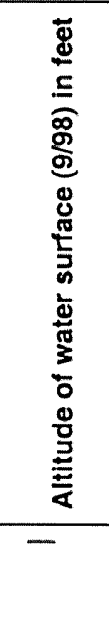 } & 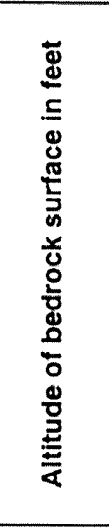 & \multirow{2}{*}{$\begin{array}{c}\begin{array}{c}\text { Source of } \\
\text { well con- } \\
\text { struction } \\
\text { data }\end{array} \\
\begin{array}{l}\text { Wilson and } \\
\text { others, } \\
1974\end{array}\end{array}$} \\
\hline WB 72TH & $\begin{array}{l}\text { Existing USGS } \\
\text { testhole record }\end{array}$ & 41 & 34 & 11.6 & 72 & 59 & 54.6 & 1966 & $\begin{array}{l}\text { test } \\
\text { hole }\end{array}$ & & & & & & & & & & 399 & \\
\hline WC 38 & Highland BR-2 & 41 & 34 & 24.8 & 73 & 0 & 2.2 & $07 / 16 / 90$ & $\mathrm{mb}$ & 475.23 & $\mathrm{r}$ & - & 49 & 46.2 & 3 & 44 & - & - & 431.23 & HRP, 1996b \\
\hline WC 39 & Highland BR-3 & 41 & 34 & 24.1 & 73 & 0 & 5.3 & $05 / 22 / 95$ & $\mathrm{mb}$ & 482 & $\mathrm{r}$ & - & 49 & 39 & 3 & 34 & 9.74 & 472.26 & 448 & ESE, 1996 \\
\hline WC 40 & Highland BR-4 & 41 & 34 & 21.2 & 72 & 59 & 55.7 & $05 / 22 / 95$ & $\mathrm{mb}$ & 468.14 & $\mathbf{r}$ & - & 103 & 92.5 & 3 & 86.5 & 9.85 & 458.29 & 381.64 & ESE, 1996 \\
\hline WC 41 & Highland MW-11 & 41 & 34 & 24.8 & 73 & 0 & 2.3 & $07 / 18 / 90$ & md & 475.3 & r & - & 43 & 33 & 2 & 43.6 & 11.97 & 463.33 & 431.7 & HRP, 1996b \\
\hline WC 42 & Highland MW-5 & 41 & 34 & 24.8 & 73 & 0 & 2.5 & $01 / 20 / 90$ & $\mathrm{~ms}$ & 475.28 & $\mathrm{r}$ & - & 16 & 6 & 2 & $>16$ & 11.55 & 463.73 & - & HRP, 1996b \\
\hline WC 43 & Highland MW-26 & 41 & 34 & 20.5 & 72 & 59 & 57.6 & $05 / 14 / 93$ & $\mathrm{~ms}$ & 472.03 & $r$ & - & 27 & 17 & 2 & $>27$ & 14.72 & 457.31 & - & HRP, 1994 \\
\hline WC 44 & Highland MW-27 & 41 & 34 & 23.5 & 72 & 59 & 56.5 & $05 / 18 / 93$ & $\mathrm{~ms}$ & 464.88 & $r$ & - & 20 & 10 & 2 & $>20$ & 6.4 & 458.48 & - & HRP, 1994 \\
\hline WC 45 & Highland MW-6 & 41 & 34 & 24.4 & 73 & 0 & 4.5 & $01 / 24 / 90$ & $\mathrm{~ms}$ & 478.77 & $r$ & - & 18 & 8 & 2 & $>18$ & 11.9 & 466.87 & - & HRP, 1996b \\
\hline WC 46 & MW-B, NEDA & 41 & 34 & 54 & 73 & 0 & 33 & $07 / 22 / 82$ & $\mathrm{mb}$ & 698.29 & s & - & 27 & 21 & 2 & 19 & 3.22 & 695.07 & 679.29 & $\mathrm{AEI}, 1994$ \\
\hline WC 47 & MW-C, NEDA & 41 & 34 & 49 & 73 & 0 & 24 & $07 / 21 / 82$ & $\mathrm{mb}$ & 709.65 & s & - & 36 & 32 & 2 & 29 & 13.63 & 696.02 & 680.65 & AEI, 1994 \\
\hline WC 48 & MW-H, NEDA & 41 & 34 & 53 & 73 & 0 & 22 & $06 / 18 / 90$ & md & 691.6 & s & - & 40 & 35 & 2 & 40.5 & 12.19 & 679.41 & 651.1 & AEI, 1994 \\
\hline WC 49 & MW-J, NEDA & 41 & 34 & 44 & 73 & 0 & 15.5 & $06 / 19 / 90$ & $\mathrm{mb}$ & 658.32 & s & - & 46 & 40.5 & 2 & 35 & 21.45 & 636.87 & 623.32 & AEI, 1994 \\
\hline WC 50 & 28 Town Line Rd. & 41 & 34 & 19.7 & 72 & 59 & 44 & $07 / 01 / 74$ & bs & 465.89 & $\mathrm{~s}$ & - & 155 & 87 & 6 & 80 & 8.43 & 457.46 & 385.89 & $\begin{array}{l}\text { Well comple- } \\
\text { tion report }\end{array}$ \\
\hline WC 51 & 41 Garthwait Rd. & 41 & 34 & 22.5 & 72 & 59 & 30.3 & $10 / 16 / 92$ & ds & 480 & $\mathrm{~m}$ & - & 245 & 42 & 6 & 30 & - & - & 450 & $\begin{array}{l}\text { Well comple- } \\
\text { tion report }\end{array}$ \\
\hline WC 52 & $\begin{array}{l}10 \text { Venus Dr. } \\
\text { MW-8a }\end{array}$ & 41 & 34 & 33.5 & 73 & 0 & 10.1 & $01 / 16 / 96$ & $\mathrm{~ms}$ & 520.67 & s & - & 14 & 4 & 2 & $>14$ & 11.98 & 508.69 & - & HRP, 1996d \\
\hline WC 53 & $\begin{array}{l}10 \text { Venus Dr. } \\
\text { MW-6c }\end{array}$ & 41 & 34 & 33.3 & 73 & 0 & 8.5 & $01 / 16 / 96$ & $\mathrm{~ms}$ & 513.7 & s & - & 15 & 5 & 2 & $>15$ & 11.45 & 502.25 & - & HRP, 1996d \\
\hline WC 54 & $\begin{array}{l}\text { Frenchie Cons. } \\
\text { HE-4 }\end{array}$ & 41 & 34 & 37.5 & 72 & 59 & 49.9 & $10 / 17 / 91$ & $\mathrm{~ms}$ & 473.79 & s & - & 13 & 3 & 2 & $>13$ & - & - & - & Heynen, 1991 \\
\hline WC 55 & $\begin{array}{l}\text { Frenchie Cons. } \\
\text { HE-2 }\end{array}$ & 41 & 34 & 36.4 & 72 & 59 & 48.8 & $10 / 17 / 91$ & $\mathrm{~ms}$ & 473.22 & s & - & 13 & 3 & 2 & $>13$ & 6.57 & 466.65 & - & Heynen, 1991 \\
\hline
\end{tabular}


Appendix 8. Selected characteristics of wells inventoried/installed by the U.S. Geological Survey--Continued

[See plate 1 for locations of wells. Well type: md, monitoring well screened in deepest part of the surficial aquifer (may be screened in till or glacial stratified deposits); mi, monitoring well screened in intermediate part of surficial aquifer; ms, monitoring well screened in shallowest part of surficial aquifer; ds, supply well at residence; ss, supply well tapping surficial aquifer; bs, supply well at a business; source of land-surface altitude data: $\mathrm{m}$, map; $\mathrm{s}$, surveyed; $\mathrm{r}$, reported; $\mathrm{cr}$, only elevation of top of casing reported; depth to water: water level in feet below measuring point if altitude of measuring point reported, otherwise water level in feet below land surface; >, greater than; - , data not available]

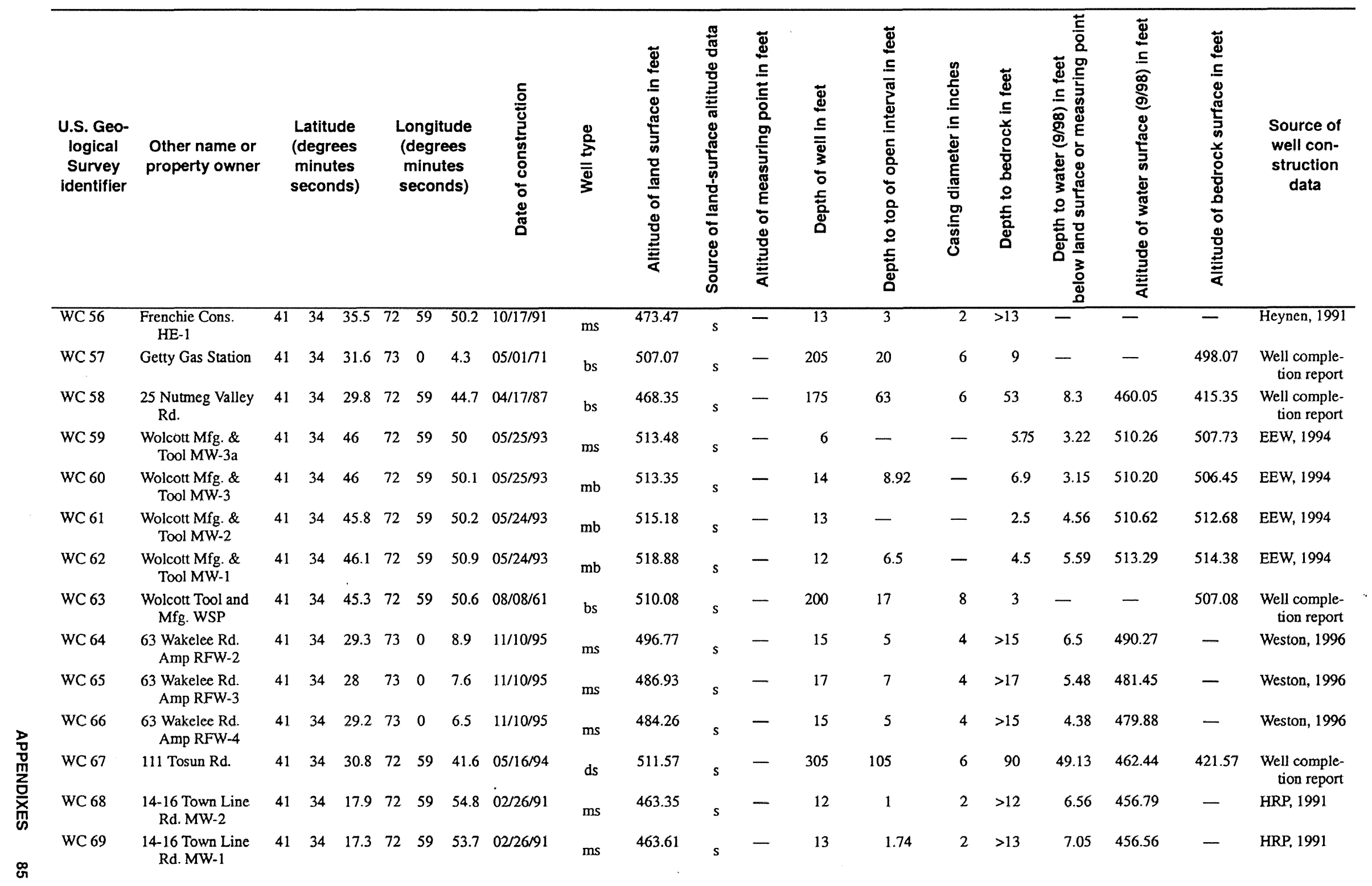


\& Appendix 8. Selected characteristics of wells inventoried/installed by the U.S. Geological Survey--Continued

[See plate 1 for locations of wells. Well type: $\mathrm{md}$, monitoring well screened in deepest part of the surficial aquifer (may be screened in till or glacial stratified deposits); mi, monitoring well screened in intermediate part of surficial aquifer; ms, monitoring well screened in shallowest part of surficial aquifer; ds, supply well at residence; ss, supply well tapping surficial aquifer; bs, supply well at a business; source
of land-surface altitude data: $\mathrm{m}$, map; $s$, surveyed; $r$, reported; cr, only elevation of top of casing reported; depth to water: water level in feet below measuring point if altitude of measuring point reported, otherwise water level in feet below land surface; >, greater than; - , data not available]

\begin{tabular}{|c|c|c|c|c|c|c|c|c|c|c|c|c|c|c|c|c|c|c|c|c|}
\hline $\begin{array}{l}\text { U.S. Geo- } \\
\text { logical } \\
\text { Survey } \\
\text { identifier }\end{array}$ & $\begin{array}{l}\text { Other name or } \\
\text { property owner }\end{array}$ & & $\begin{array}{l}\text { Latitu } \\
\text { (degr } \\
\text { minu } \\
\text { secon }\end{array}$ & & & $\begin{array}{l}\text {-ongit } \\
\text { (degr } \\
\text { minu } \\
\text { secon }\end{array}$ & $\begin{array}{l}\text { tude } \\
\text { ees } \\
\text { tes } \\
\text { ids) }\end{array}$ & 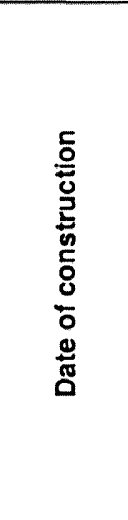 & $\frac{\$}{\sum}$ & 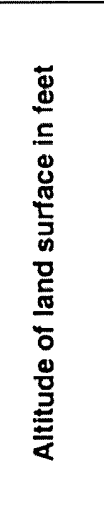 & 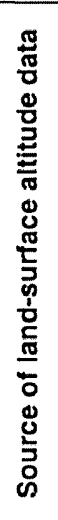 & 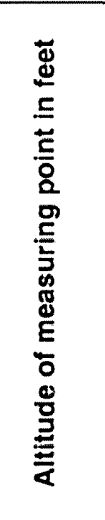 & 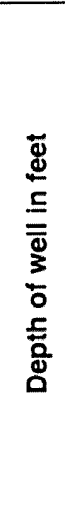 & 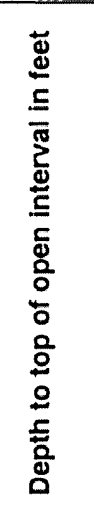 & 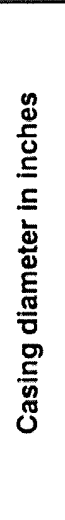 & 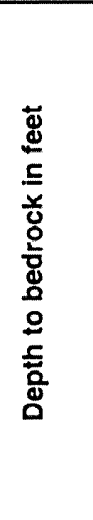 & 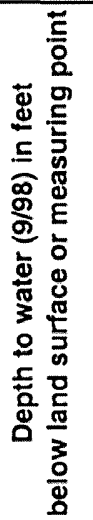 & 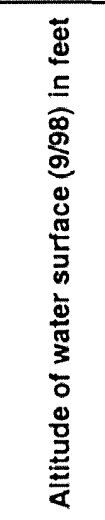 & 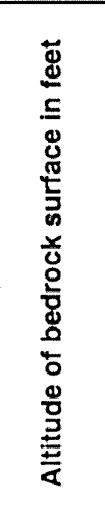 & $\begin{array}{l}\text { Source of } \\
\text { well con- } \\
\text { struction } \\
\text { data }\end{array}$ \\
\hline WC 70 & 32 Wolcott Rd. & 41 & 34 & 29.4 & 73 & 0 & 3.1 & $=$ & $\mathrm{ds}$ & 489 & $\mathrm{~s}$ & - & - & - & - & - & - & - & - & - \\
\hline WC 71 & 16 Wakelee Rd. & 41 & 34 & 34.7 & 73 & 0 & 3.2 & - & ds & 516.41 & s & - & - & - & - & - & - & - & - & $\begin{array}{l}\text { Shallow dug } \\
\text { well }\end{array}$ \\
\hline WC 72 & $\begin{array}{l}148 \text { Tosun Rd. } \\
\text { Flammia }\end{array}$ & 41 & 34 & 30.7 & 72 & 59 & 49.2 & - & bs & 465.49 & s & - & - & - & - & - & - & - & - & Dug well \\
\hline WC 73 & 114 Tosun Rd. & 41 & 34 & 32.6 & 72 & 59 & 40.1 & - & ds & 537.96 & $s$ & - & - & - & - & - & 54.68 & 483.28 & - & - \\
\hline WC 74 & 108 Tosun Rd. & 41 & 34 & 31.6 & 72 & 59 & 39.2 & - & ds & 533.97 & $\mathrm{~s}$ & - & - & - & - & - & - & - & - & - \\
\hline WC 75 & 78 Tosun Rd. & 41 & 34 & 35.4 & 72 & 59 & 40.7 & - & $\mathrm{ds}$ & 547.7 & $s$ & - & - & - & - & - & - & - & - & - \\
\hline WC 76 & 72 Tosun Rd. & 41 & 34 & 35.5 & 72 & 59 & 41.7 & - & ds & 537.79 & $\mathrm{~s}$ & - & - & - & - & - & 47.3 & 490.49 & - & - \\
\hline WC 77 & $\begin{array}{l}\text { Brave Equip. } \\
\text { MW-1 }\end{array}$ & 41 & 34 & 25.6 & 72 & 59 & 38.3 & $09 / 26 / 90$ & $\mathrm{~ms}$ & 463.77 & s & - & 14 & 3 & 2 & $>13.5$ & 4.95 & 458.82 & - & $\begin{array}{l}\text { CTDEP, writ- } \\
\text { ten com- } \\
\text { mun., } 1996\end{array}$ \\
\hline WC 78 & $\begin{array}{l}31 \text { Nutmeg Valley } \\
\text { Rd. Maaco }\end{array}$ & 41 & 34 & 27.7 & 72 & 59 & 39.4 & - & bs & 465.54 & $\mathbf{s}$ & - & - & - & - & - & 6.38 & 459.16 & - & - \\
\hline WC 80 & Joseph Pagano & 41 & 34 & 16.7 & 72 & 59 & 55.1 & $03 / 24 / 98$ & $\mathrm{md}$ & 460.1 & $s$ & 461.09 & 67 & 65.48 & 2 & 76 & 4.79 & 456.30 & 384.1 & USGS \\
\hline WC 81 & Joseph Pagano & 41 & 34 & 16.7 & 72 & 59 & 55.1 & $03 / 24 / 98$ & $\mathrm{mi}$. & 460.29 & $\mathrm{~s}$ & 461.37 & 40 & 37.94 & 2 & 76 & 5.06 & 456.31 & 384.29 & USGS \\
\hline WC 82 & Joseph Pagano & 41 & 34 & 16.7 & 72 & 59 & 55.1 & $03 / 24 / 98$ & $\mathrm{~ms}$ & 460.25 & $\mathrm{~s}$ & 461.15 & 12 & 10.18 & 2 & 76 & 7,49 & 453.66 & 384.25 & USGS \\
\hline WC 83 & Joseph Pagano & 41 & 34 & 16.7 & 72 & 59 & 55.1 & $04 / 28 / 98$ & $\mathrm{mb}$ & 460.41 & $s$ & 461.13 & 164 & 79.4 & 6 & 71 & 4.69 & 456.44 & 389.41 & USGS \\
\hline WC 84 & $\begin{array}{l}\text { Mattatuck Scrap } \\
\text { Metal }\end{array}$ & 41 & 34 & 21.4 & 72 & 59 & 49.2 & $03 / 17 / 98$ & md & 462.13 & s & 463.36 & 66 & 64.38 & 2 & 67 & 5.72 & 457.64 & 395.13 & USGS \\
\hline WC 85 & $\begin{array}{l}\text { Mattatuck Scrap } \\
\text { Metal }\end{array}$ & 41 & 34 & 21.4 & 72 & 59 & 49.2 & $03 / 18 / 98$ & $\mathrm{mi}$ & 462.13 & s & 463.21 & 38 & 35.94 & 2 & 67 & 5.52 & 457.69 & 395.13 & USGS \\
\hline WC 86 & $\begin{array}{l}\text { Mattatuck Scrap } \\
\text { Metal }\end{array}$ & 41 & 34 & 21.4 & 72 & 59 & 49.2 & $03 / 18 / 98$ & $\mathrm{~ms}$ & 462.18 & s & 463.38 & 17 & 14.57 & 2 & 67 & 5.73 & 457.65 & 395.18 & USGS \\
\hline WC 87 & Sendzimir estate & 41 & 34 & 23.9 & 72 & 59 & 40.6 & $03 / 26 / 98$ & $\mathrm{md}$ & 463.82 & $\mathrm{~s}$ & 463.56 & 50 & 47.86 & 2 & 63 & 4.66 & 458.90 & 400.82 & USGS \\
\hline WC 88 & Sendzimir estate & 41 & 34 & 23.9 & 72 & 59 & 40.6 & $03 / 26 / 98$ & $\mathrm{mi}$ & 463.88 & s & 463.57 & 31 & 28.53 & 2 & 63 & 4.34 & 459.23 & 400.88 & USGS \\
\hline WC 89 & Sendzimir estate & 41 & 34 & 23.9 & 72 & 59 & 40.6 & $03 / 26 / 98$ & $\mathrm{~ms}$ & 464 & s & 463.63 & 12 & 10.23 & 2 & 63 & 4.51 & 459.12 & 401 & USGS \\
\hline
\end{tabular}


Appendix 8. Selected characteristics of wells inventoried/installed by the U.S. Geological Survey--Continued

[See plate 1 for locations of wells. Well type: md, monitoring well screened in deepest part of the surficial aquifer (may be screened in till or glacial stratified deposits); mi, monitoring well screened in intermediate part of surficial aquifer; ms, monitoring well screened in shallowest part of surficial aquifer; ds, supply well at residence; ss, supply well tapping surficial aquifer; bs, supply well at a business; source of land-surface altitude data: $\mathrm{m}$, map; $s$, surveyed; $r$, reported; cr, only elevation of top of casing reported; depth to water: water level in feet below measuring point if altitude of measuring point reported, otherwise water level in feet below land surface; $>$, greater than; - , data not available]

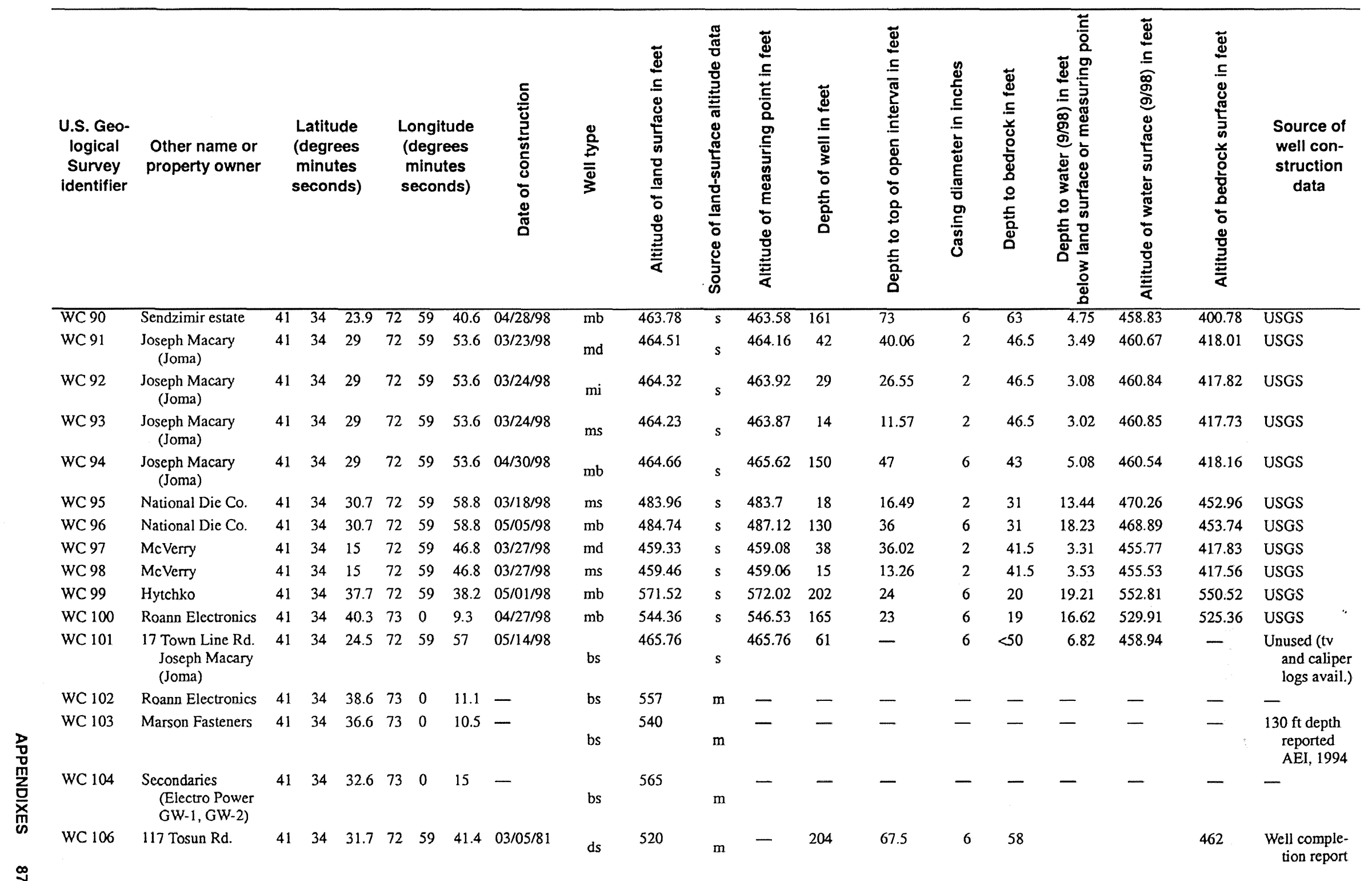


\% Appendix 8. Selected characteristics of wells inventoried/installed by the U.S. Geological Survey--Continued

[See plate 1 for locations of wells. Well type: $\mathrm{md}$, monitoring well screened in deepest part of the surficial aquifer (may be screened in till or glacial stratified deposits); mi, monitoring well screened in intermediate part of surficial aquifer; $\mathrm{ms}$, monitoring well screened in shallowest part of surficial aquifer; ds, supply well at residence; ss, supply well tapping surficial aquifer; bs, supply well at a business; source

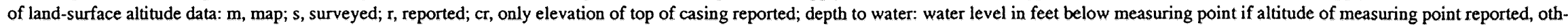
erwise water level in feet below land surface; $>$, greater than; - , data not available]

\begin{tabular}{|c|c|c|c|c|c|c|c|c|c|c|c|c|c|c|c|c|c|c|c|c|}
\hline $\begin{array}{l}\text { U.S. Geo- } \\
\text { logical } \\
\text { Survey } \\
\text { Identifier }\end{array}$ & $\begin{array}{l}\text { Other name or } \\
\text { property owner }\end{array}$ & & $\begin{array}{l}\text { Latituc } \\
\text { degre } \\
\text { minute } \\
\text { seconc }\end{array}$ & & & $\begin{array}{l}\text { ongit } \\
\text { (degre } \\
\text { minut } \\
\text { secon }\end{array}$ & $\begin{array}{l}\text { ude } \\
\text { ees } \\
\text { tes } \\
\text { ids) }\end{array}$ & 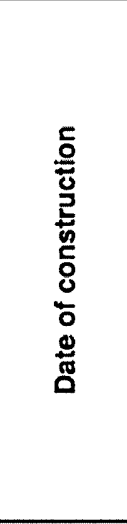 & $\frac{\stackrel{8}{2}}{\overline{\bar{c}}}$ & 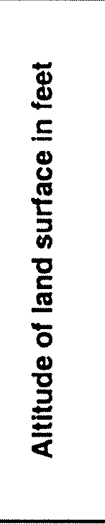 & 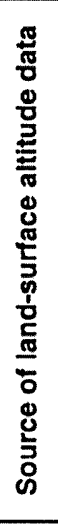 & 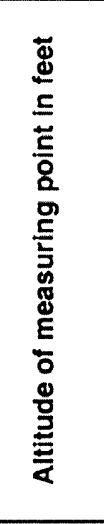 & 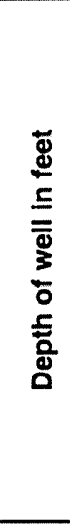 & 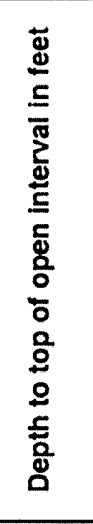 & 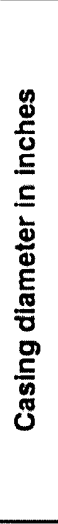 & 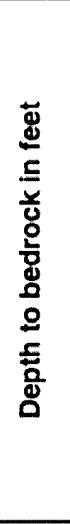 & 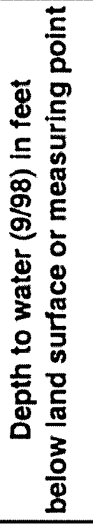 & 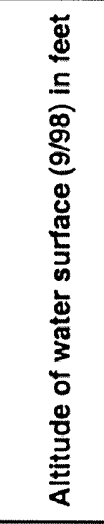 & 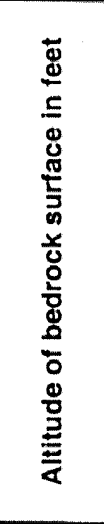 & $\begin{array}{l}\text { Source of } \\
\text { well con- } \\
\text { struction } \\
\text { data }\end{array}$ \\
\hline WC 107 & 54 Tosun Rd. & 41 & 34 & 34.7 & 72 & 59 & 45.4 & - & ds & 499 & $\mathrm{~m}$ & - & - & - & - & - & - & - & $=$ & - \\
\hline WC 108 & Anstro MW-4 & 41 & 34 & 39 & 72 & 59 & 47.9 & - & $\mathrm{mb}$ & 491.77 & $s$ & 493.77 & 89 & 11 & 6 & 3 & 22.52 & 471.25 & 488.77 & HRP, 1998 \\
\hline WC 109 & Anstro MW-2 & 41 & 34 & 40.9 & 72 & 59 & 50.1 & - & $\mathrm{mb}$ & 479.31 & $s$ & 479.31 & 61 & 38.62 & 6 & 26 & 6.84 & 472.47 & 453.31 & HRP, 1998 \\
\hline WC 110 & Anstro MW-1 & 41 & 34 & 40.9 & 72 & 59 & 50.1 & - & $\mathrm{ms}$ & 479.51 & $s$ & 479.51 & 15 & 5.09 & 2 & & 7 & 472.51 & & HRP, 1998 \\
\hline WC 111 & 66 Tosun Rd. & 41 & 34 & 34.4 & 72 & 59 & 42.7 & $03 / 17 / 87$ & ds & 526.18 & $s$ & - & 245 & 78 & 6 & 66 & 47.63 & 478.55 & 460.18 & $\begin{array}{r}\text { Well comple- } \\
\text { tion report }\end{array}$ \\
\hline WC 112 & 129 Tosun Rd. & 41 & 34 & 33.2 & 72 & 59 & 42.5 & - & ds & 520 & $\mathrm{~m}$ & - & 163 & 80.7 & 6 & 57 & - & - & 463 & $\begin{array}{l}\text { Well comple- } \\
\text { tion report }\end{array}$ \\
\hline WC 113 & 123 Tosun Rd. & 41 & 34 & 32.3 & 72 & 59 & 42 & - & ds & 520 & $\mathrm{~m}$ & - & 160 & 81 & 6 & 58 & - & - & 462 & $\begin{array}{l}\text { Well comple- } \\
\text { tion report }\end{array}$ \\
\hline WC 114 & Anstro MW-3 & 41 & 34 & 42 & 72 & 59 & 46.2 & $10 / 15 / 97$ & $\mathrm{mb}$ & 514.04 & $s$ & 516.05 & 313 & 9 & 6 & 5 & 35.84 & 480.21 & 509.04 & HRP, 1998 \\
\hline WC 115 & Marson MW-2 & 41 & 34 & 37.8 & 73 & 0 & 11.6 & - & $\mathrm{ms}$ & 549.07 & s & - & - & - & - & - & 4.38 & 544.69 & - & $\begin{array}{l}\text { Dames and } \\
\text { Moore, } \\
1995\end{array}$ \\
\hline WC 116 & Marson MW-3 & 41 & 34 & 36.1 & 73 & 0 & 10.7 & - & $\mathrm{ms}$ & 542.32 & s & - & 12 & 7 & 2 & 10 & 10.45 & 531.87 & 532.32 & $\begin{array}{r}\text { Well comple- } \\
\text { tion report }\end{array}$ \\
\hline WC 117 & Marson MW-1 & 41 & 34 & 35.9 & 73 & 0 & 12.1 & - & $\mathrm{ms}$ & 548.02 & s & - & - & - & - & - & dry & - & - & $\begin{array}{l}\text { Dames and } \\
\text { Moore, } \\
1995\end{array}$ \\
\hline WC 118 & $\begin{array}{l}\text { Existing well } \\
\text { Sendzimir estate }\end{array}$ & 41 & 34 & 26.3 & 72 & 59 & 42.1 & - & $\mathrm{ms}$ & 462.5 & s & 465.62 & - & - & - & - & 6.85 & 458.77 & - & - \\
\hline WC 119 & $\begin{array}{l}\text { Existing well } \\
\text { Maaco property }\end{array}$ & 41 & 34 & 27 & 72 & 59 & 21.2 & - & $\mathrm{ms}$ & 469.5 & $\mathrm{~m}$ & - & - & - & - & - & 2.65 & 466.85 & - & - \\
\hline WC 120 & $\begin{array}{l}10 \text { Venus Dr. } \\
\text { MW-5 }\end{array}$ & 41 & 34 & 35 & 73 & 0 & 9.5 & - & $\mathrm{m}$ & 519.47 & $\mathbf{s}$ & - & - & - & - & - & 7.84 & 511.63 & - & HRP, 1996d \\
\hline WC 121 & $\begin{array}{l}10 \text { Venus Dr. } \\
\text { MW-7 }\end{array}$ & 41 & 34 & 35.2 & 73 & 0 & 8.6 & - & $\mathrm{ms}$ & 516.43 & s & - & 12 & 2 & 2 & $>12$ & 6.62 & 509.81 & - & HRP, 1996d \\
\hline
\end{tabular}


Appendix 8. Selected characteristics of wells inventoried/installed by the U.S. Geological Survey--Continued

[See plate 1 for locations of wells. Well type: $\mathrm{md}$, monitoring well screened in deepest part of the surficial aquifer (may be screened in till or glacial stratified deposits); mi, monitoring well screened in intermediate part of surficial aquifer; ms, monitoring well screened in shallowest part of surficial aquifer; ds, supply well at residence; ss, supply well tapping surficial aquifer; bs, supply well at a business; source of land-surface altitude data: $m$, map; $s$, surveyed; $r$, reported; $c r$, only elevation of top of casing reported; depth to water: water level in feet below measuring point if altitude of measuring point reported, otherwise water level in feet below land surface; $>$, greater than; - , data not available]

\begin{tabular}{|c|c|c|c|c|c|c|c|c|c|c|c|c|c|c|c|c|c|c|c|c|}
\hline $\begin{array}{l}\text { U.S. Geo- } \\
\text { logical } \\
\text { Survey } \\
\text { identifier }\end{array}$ & $\begin{array}{l}\text { Other name or } \\
\text { property owner }\end{array}$ & & $\begin{array}{l}\text { Latitu } \\
\text { (degre } \\
\text { minut } \\
\text { secon }\end{array}$ & & & $\begin{array}{l}\text { ongit } \\
\text { (degre } \\
\text { minut } \\
\text { secon }\end{array}$ & & 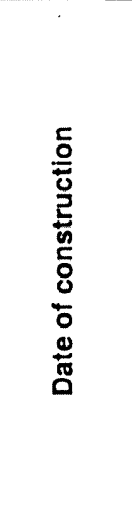 & 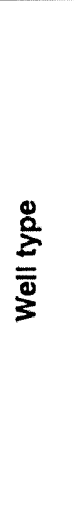 & 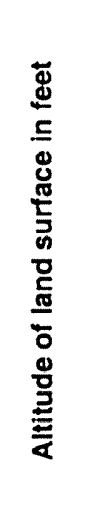 & 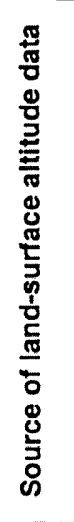 & 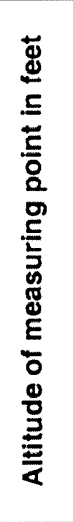 & 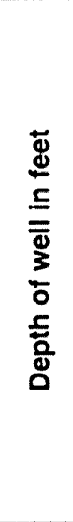 & 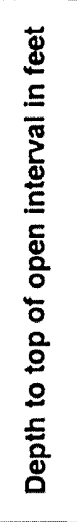 & 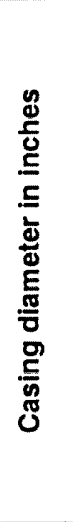 & 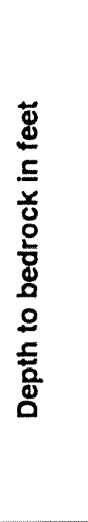 & 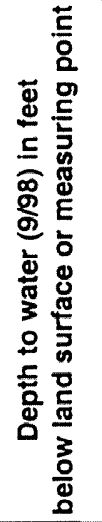 & 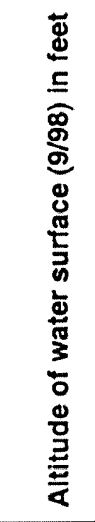 & 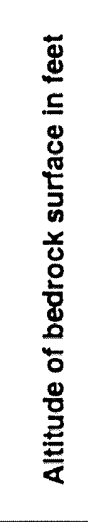 & $\begin{array}{l}\text { Source of } \\
\text { well con- } \\
\text { struction } \\
\text { data }\end{array}$ \\
\hline WC 122 & $\begin{array}{l}10 \text { Venus Dr. } \\
\text { MW-4 }\end{array}$ & 41 & 34 & 34.7 & 73 & 0 & 7.7 & - & $\mathrm{m}$ & 513.61 & $\mathrm{~s}$ & - & $=$ & $=$ & - & - & 8.43 & 505.18 & $=$ & HRP, 1996d \\
\hline WC 123 & Highland MW-28 & 41 & 34 & 22.2 & 72 & 59 & 56.9 & $05 / 18 / 93$ & $\mathrm{md}$ & 467.4 & c & - & 64 & 54 & 2 & 67 & - & - & 400.4 & HRP, 1994 \\
\hline WC 124 & $\begin{array}{l}\text { Talk of the Town } \\
\text { restaurant }\end{array}$ & 41 & 34 & 35.9 & 73 & 0 & 0.3 & $04 / 21 / 69$ & bs & 515 & $\mathrm{~m}$ & - & 203 & 30 & 6 & 12 & - & - & 503 & $\begin{array}{l}\text { Well comple- } \\
\text { tion report }\end{array}$ \\
\hline WC 125 & Line Manufacturing & 41 & 34 & 26.8 & 73 & 0 & 3.6 & $08 / 07 / 65$ & bs & 475 & $\mathrm{~m}$ & - & 225 & 47 & 6 & 18 & - & - & 457 & $\begin{array}{r}\text { Well comple- } \\
\text { tion report }\end{array}$ \\
\hline WC 128 & $\begin{array}{l}\text { Waterbury Heat } \\
\text { Treating } \\
\text { WHT3MW }\end{array}$ & 41 & 34 & 34.1 & 72 & 59 & 59 & $04 / 30 / 87$ & $\mathrm{~ms}$ & 499 & $\mathrm{~m}$ & - & 20 & 9.8 & 2 & 20 & - & - & - & HRP, 1986 \\
\hline WC 129 & Dollinger & 41 & 34 & 30.6 & 73 & 0 & 9.4 & - & bs & 555 & $\mathrm{~m}$ & - & - & - & - & 8 & - & - & 547 & $\begin{array}{l}\text { Well comple- } \\
\text { tion Report }\end{array}$ \\
\hline
\end{tabular}


๑ ำ

은

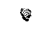

음.

$\cong$ क

文

舟 우

$\sum_{\text {Dे }} \vec{\nabla}$

可

ग

8

ติ

产

员 